\begin{abstract}
UNIVERSIDADE DE SÃO PAULO
FACULDADE DE FILOSOFIA, LETRAS E CIÊNCIAS HUMANAS

DEPARTAMENTO DE LETRAS CLÁSSICAS E VERNÁCULAS

PROGRAMA DE PÓS-GRADUAÇÃO EM LITERATURA PORTUGUESA
\end{abstract}

MARCELO LACHAT

A lírica amorosa seiscentista: poesia de amor agudo 


$$
\text { UNIVERSIDADE DE SÃO PAULO }
$$

FACULDADE DE FILOSOFIA, LETRAS E CIÊNCIAS HUMANAS DEPARTAMENTO DE LETRAS CLÁSSICAS E VERNÁCULAS PROGRAMA DE PÓS-GRADUAÇÃO EM LITERATURA PORTUGUESA

\title{
A lírica amorosa seiscentista: poesia de amor agudo
}

\author{
Marcelo Lachat
}

\begin{abstract}
Tese apresentada ao Programa de PósGraduação em Literatura Portuguesa do Departamento de Letras Clássicas e Vernáculas da Faculdade de Filosofia, Letras e Ciências Humanas da Universidade de São Paulo, para a obtenção do título de Doutor em Letras.
\end{abstract}

Orientadora: Profa. Dra. Adma Fadul Muhana 
À Renata,

interminável fio em labirintos de amor. 


\section{Agradecimentos}

Aos meus pais, Claudio e Nicea; aos meus irmãos, Claudia e Mauricio; aos meus cunhados, Paulo e Carol; e aos meus sobrinhos, Ricardo e Maria Clara.

À minha orientadora, professora Adma Fadul Muhana.

Aos professores Helder Garmes, Isabel Almeida, Jacqueline Penjon e Maria do Socorro Fernandes de Carvalho.

Aos meus amigos, em especial, a Aline David, Bruno Penteado Natividade Moreto, Carla Cristina de Paula, Fernanda Canavêz, Flávio Antônio Fernandes Reis, Jonathan Boureau, Lauro Luiz Pereira Silva, Leandro Rodrigues Alves Diniz, Lenon Rogério de Melo Franco, Louise Aguiar, Marco Büchel, Marilena Inácio de Souza, Martje Geeraerts e Osmilto Moreira Silva.

A Sebastião José da Silva e Célia Dalva da Silva.

Aos funcionários da Biblioteca Nacional de Lisboa, da Biblioteca da Ajuda, do Arquivo Nacional da Torre do Tombo, da Biblioteca Pública de Braga e da Biblioteca Pública de Évora.

À Fundação de Amparo à Pesquisa do Estado de São Paulo (FAPESP) e à Pró-Reitoria de Pós-Graduação da Universidade de São Paulo. 
Resiste um pouco, ó Fábio, a teu tormento,

Que amor é labirinto sem saída.

(Antônio Barbosa Bacelar)

Amar sem padecer, é grande dita; mas dita, que não dá merecimento; que a pureza do amor, mais se acredita na ausência, na firmeza, e no tormento.

(Bernardo Vieira Ravasco) 


\section{Resumo}

Este trabalho discute as especificidades da poesia seiscentista produzida em Portugal e no Brasil Colônia, propondo a noção de amor agudo para caracterizar sua variada lírica amorosa. Em busca desse objetivo, a leitura dos poemas segue os caminhos da imitação, termo fundamental para se compreender a produção retórico-poética dos séculos XVI e XVII. Os poemas líricos dos quais partem as análises, ou seja, tanto aqueles autorizados (ainda que, muitas vezes, com atribuições de autoria questionáveis) pelos nomes de reconhecidos poetas seiscentistas, como Antônio Barbosa Bacelar, D. Francisco Manuel de Melo, Frei Antônio das Chagas, Gregório de Matos, Jerônimo Baía, Manuel Botelho de Oliveira e Violante do Céu, quanto aqueles ditos anônimos ou de autoridades poéticas menos constituídas, como Bernardo Vieira Ravasco e Manuel de Faria e Sousa, todos eles, enquanto imitações, exigiam dos leitores ou ouvintes cultos da época o reconhecimento de seus modelos poéticos; por isso, este estudo recorre, frequentemente, a Camões e Góngora, por exemplo. Porém, imitar as auctoritates para se fazer auctoritas, no século XVII, não era apenas copiar servilmente; os poetas seiscentistas emulavam seus modelos, elaborando composições engenhosas e agudas mais adequadas ao decoro dos tempos. Desse modo, a agudeza é noção central na preceptiva retóricopoética seiscentista e, portanto, também o é neste estudo. Como se procura demonstrar, dessa poesia aguda decorre a confecção de um amor igualmente agudo, isto é, um amor que não é expressão subjetiva e original de indivíduo algum, mas que aparece em poemas cujos efeitos inesperados são retórica e poeticamente construídos. Fruto de imitações, o amor agudo é ovidiano, cortês, petrarquista, camoniano, marinista, gongórico; miscelânea de doutrinas, é platônico, estoico, epicurista, cristão; definindoo, nesta tese, pretende-se reunir a variedade poética da lírica amorosa seiscentista, feito agudo caule que sustenta cultas flores.

Palavras-chave: literatura portuguesa; poesia lírica do século XVII; poética e retórica; agudeza; amor. 


\begin{abstract}
The present work articulates the specificities of $17^{\text {th }}$-century poetry produced in Portugal and in Colonial Brazil as it proposes the notion of witty love to characterize its diverse love lyric poems. Pursuing this perspective, the reading of these poems follows the path of imitation, a fundamental term to understand the rhetorico-poetic production of the $16^{\text {th }}$ and $17^{\text {th }}$ centuries. The lyric poems from which the analyses depart, that is, both those penned (despite a questionable attribution of authorship in many cases) by well-known $17^{\text {th }}$-century poets such as Antônio Barbosa Bacelar, D. Francisco Manuel de Melo, Frei Antônio das Chagas, Gregório de Matos, Jerônimo Baía, Manuel Botelho de Oliveira, and Violante do Céu, and those deemed anonymous or with a less constituted poetic authorship, such as Bernardo Vieira Ravasco and Manuel de Faria e Sousa, all these poems, as imitations, demanded that the learned readers or listeners of the time recognize their poetic models; for this reason, this study often draws from Camões and Góngora, for instance. In any event, in the $17^{\text {th }}$ century imitating the auctoritates to forge auctoritas did not only mean to copy obsequiously; $17^{\text {th }}$-century poets emulated their models, crafting ingenious and witty compositions that were more suitable to the decorum in vogue. Thus wit is a central notion in $17^{\text {th }}$-century rhetoricopoetic precepts, and it will also be so in this study. As I will demonstrate, from this wit poetry ensues the crafting of an equally witty love, that is, a love that is not the subjective and original expression of any individual, but one which is present in poems whose unexpected effects are rhetorically and poetically forged. The fruit of imitations, witty love is Ovidian, courtly, Petrarchan, Camonian, Marinist, Gongorian; miscellanea of doctrines, it is Platonic, Stoic, Epicurean, Christian; by defining it in this dissertation, I intend to gather the poetic variety of $17^{\text {th }}$-century love lyric, like an acute stem that supports learned flowers.
\end{abstract}

Key words: portuguese literature; $17^{\text {th }}$-century lyric poetry; poetics and rhetoric; wit; love. 


\section{Sumário}

INTRODUÇÃO

\section{CAPÍTULO 1}

A lírica seiscentista: gênero de cultivo do amor agudo

.14

\section{CAPÍTULO 2}

De cultas flores e fontes várias se compõe o amor agudo

\section{CAPÍTULO 3}

As finezas amorosas do canto escrito seiscentista

\section{ANEXO}

Saudades de Lídia e Armido

Poema atribuído a Bernardo Vieira Ravasco. 


\section{Introdução}

A poesia do século XVII é, ao mesmo tempo, singular e vária. Sua singularidade deve ser buscada em meio à variedade dos conceitos e à diversidade de gêneros e subgêneros poéticos. O que aproxima essa abundante produção seiscentista de sonetos, romances, décimas, canções, madrigais e glosas (apenas para citar os "gêneros de composição"1 mais correntes na lírica do século XVII) não é somente o aspecto temporal, mas também procedimentos poéticos comuns que determinam uma poética específica, centrada na noção de agudeza, como já o demonstrou Maria do Socorro Fernandes de Carvalho ${ }^{2}$ e como discutiremos, detidamente, no primeiro capítulo deste trabalho. Assim, a poesia aguda de que trataremos neste estudo, como se observará, é aquela produzida, principalmente, na Península Ibérica e no Brasil Colônia, entre fins do século XVI e começo do século XVIII. Embora a maior parte dessa poesia tenha sido composta no século XVII, ao denominá-la "seiscentista", foca-se mais a predominância de modelos e procedimentos poéticos do que o momento de produção ou publicação dos poemas, que em diversos casos apresentam autoria e datação incertas.

Nesse sentido, é preciso ressaltar que se evitará considerar a poesia do século XVII "barroca", pois esse uso dedutivo do termo, estranho aos escritos seiscentistas, advém da manutenção de uma tradição idealista da historiografia da arte do século XIX; em especial, decorre da noção de "barroco" formulada por Heinrich Wölfflin, em sua obra Renaissance und Barock (1888). ${ }^{3}$ Até o começo do século XVIII, a palavra "barroco" não designava qualquer "estilo", "período" ou "movimento" artístico ou literário, sendo empregada, principalmente, para significar uma pérola irregular, como se verifica, por exemplo, no Vocabulário Português e Latino de Raphael Bluteau: ${ }^{4}$

\footnotetext{
${ }^{1}$ Manuel de Faria e Sousa, na quinta parte de sua Fuente de Aganipe (obra que será citada muitas vezes neste trabalho), é que utiliza a expressão "gêneros de composição", ao intitular seu prólogo como um "discurso acerca de los generos de composiciones que ay en esa Parte quinta".

${ }^{2}$ Carvalho, M. S. F. de. Poesia de agudeza em Portugal: estudo retórico da poesia lírica e satírica escrita em Portugal no século XVII. São Paulo: Humanitas; Edusp; Fapesp, 2007.

${ }^{3}$ Cf. Hansen, J. A. "Barroco, Neobarroco e Outras Ruínas". In: REEL - Revista Eletrônica de Estudos Literários. Vitória, a.2, n.2, 2006, pp.1-4. Disponível em: http://www.ufes.br/ mlb/reel2/ JoaoAdolfoHansen.pdf

${ }^{4}$ Vocabulario Portuguez, \& Latino. Coimbra: No Collegio das Artes da Companhia de Jesu, 1712-1713, vols.1-4. Lisboa Occidental: Na Officina de Pascoal da Sylva, 1716-1721, vols. 5-8. Suplemento ao Vocabulario Portuguez, e Latino. 2v. Lisboa Occidental: Na Officina de Joseph Antonio da Sylva, 1727;
} 
"Barroco. Pérola tosca, \& desigual, que nem é comprida, nem redonda. Unio, dives $a$ ab rotunda, \& turbata in figura". 5 a própria escolha desse termo indica uma concepção dedutiva da história literária, que classifica autores e obras segundo estilos e épocas prédeterminados: as joias bem polidas e regulares do classicismo teriam dado lugar às pérolas toscas e deformadas do barroco. Como consequência desse modo de avaliar a "literatura" (uma palavra também bastante inadequada para designar a produção retórico-poética do século XVII), as representações seiscentistas foram, acriticamente, transformadas em "barroco", cuja noção, conforme esclarece João Adolfo Hansen, promove uma interpretação idealista, "que generaliza as categorias neoclássicas para fundamentar as avaliações da poesia seiscentista como 'excesso', 'jogo de palavras', 'alambicamento', 'artificialismo', 'formalismo', 'niilismo temático', 'afetação', 'pedantismo' e mais anacronismos". 6

Para escapar de tal idealização, uma possível saída é recorrer àquilo que enforma os textos seiscentistas, em especial, às technai retórica e poética e às matérias elaboradas tecnicamente. Em vez de buscar aquelas características ditas "barrocas" de uma obra do século XVII, parece mais produtivo tentar identificar procedimentos retóricos e poéticos que, desenvolvendo com palavras as res, constituem o texto. No caso particular desta tese, procura-se reunir, discutindo-se as especificidades da poesia seiscentista produzida em Portugal e no Brasil Colônia, aquelas técnicas e a matéria principal de uma das vertentes dessa produção poética: daí propor-se a noção de amor agudo para caracterizar a variada lírica amorosa dos anos Seiscentos. Com essa concepção, pretende-se destacar que se trata de um amor construído retórica e poeticamente, ou seja, que segue preceitos, que atende à verossimilhança e ao decoro, que não é expressão subjetiva e original de indivíduo algum, mas que aparece em poemas cujos efeitos são racionalmente construídos. Além disso, referindo-se a um "amor agudo", tenta-se reunir res e uerba, ou ainda, invenção e elocução, da mesma forma que nos poemas os conceitos e as palavras são indissociáveis.

Visando a esse propósito de definir a concepção amorosa da poesia lírica do século XVII, nosso trabalho parte de uma discussão do gênero lírico que, diferentemente do épico ou do trágico, não contou, nos anos Seiscentos, com uma

Na Patriarcal Officina da Musica, 1728. Consultamos a seguinte edição fac-similada: Hildesheim; Zürich; New York: Georg Olms Verlag, 2002. 10v.

${ }^{5}$ Bluteau, R. Vocabulario Portuguez, \& Latino, op.cit., volume 2, verb. "barroco", p.58.

${ }^{6}$ Hansen, J. A. "Fênix renascida \& Postilhão de Apolo: Uma introdução". In: Poesia seiscentista - Fênix renascida \& Postilhão de Apolo. 1ªd. São Paulo: Hedra, 2002, p.26. 
preceptiva retórico-poética específica e unívoca. Devido a tal escassez normativa, pareceu-nos adequado, entre outras coisas, analisar detidamente, no primeiro capítulo da tese, o Trattato della poesia lirica (1594), de Pomponio Torelli, um dos poucos tratados que, em fins do século XVI, têm a lírica como matéria principal, buscando caracterizá-la de acordo com preceitos retóricos e poéticos, antigos e modernos. Por isso, as considerações de Torelli permeiam todo o primeiro capítulo do trabalho, pois permitem direcionar para o gênero lírico as discussões de diversos outros preceptistas, também apresentadas ao longo do nosso texto, sobre noções fundamentais para a produção retórico-poética seiscentista, tais como a imitação, a autoridade, a agudeza e a finalidade principal da poesia (delectare ou docere). Buscam-se, dessa maneira, peculiaridades da lírica amorosa, não só porque nessa poesia se constitui o amor agudo, mas também para mostrar que a constituição desse gênero depende de sua aguda matéria amorosa.

Se no primeiro capítulo discutem-se as especificidades da imitação lírica, inicia-se o segundo discorrendo acerca da noção de estilo, já que o estilo é determinante na imitação. Para tratar desse assunto, dois autores (embora tenhamos recorrido a outros) são fundamentais: Tasso e Gracián. A partir da concepção de estilo, em geral, tentamos caracterizar o estilo lírico da poesia amorosa seiscentista, porque este, em particular, é que torna agudo, ornando com suas cultas flores, o amor. E algumas fontes que dão viço a esse amor, como a platônica, a estoica e a cristã, são estudadas no segundo capítulo, no qual salientamos a importância da conciliação dessas doutrinas para a "invenção" (sempre poética) do amor agudo. Fazemos isso pautando-nos pelos poemas seiscentistas, pois são eles que formam o culto e vasto campo em que floresce tal concepção amorosa. Entre esses poemas, analisamos tanto aqueles de mais fácil acesso e, possivelmente, mais conhecidos, que já constam em edições contemporâneas de poesia do século XVII, quanto aqueles, mais raros, que só podem ser lidos em impressos e manuscritos seiscentistas e setecentistas, ${ }^{7}$ como é o caso de algumas

\footnotetext{
7 Vale destacar que o contato com esses impressos e manuscritos seiscentistas e setecentistas foi possibilitado, especialmente, pelos dois estágios de pesquisa que o doutorando realizou no exterior. No primeiro, o doutorando, tendo sido seu projeto de pesquisa selecionado pela Pró-Reitoria de PósGraduação da Universidade de São Paulo, participou do "Programa de Mobilidade Internacional de PósGraduandos" que, com o apoio do Santander, disponibilizou uma bolsa de estudos para o desenvolvimento de um estágio de cinco meses (de abril a agosto de 2010) em Portugal, na Universidade de Lisboa. Durante esse período, o pós-graduando fez diversas pesquisas em bibliotecas e arquivos portugueses, sendo supervisionado pela Profa. Dra. Isabel Almeida, docente do Departamento de Literaturas Românicas da Faculdade de Letras da Universidade de Lisboa. Já o segundo estágio, viabilizado pelo uso dos recursos da reserva técnica da bolsa de doutorado da Fapesp, foi realizado na França, na Universidade Paris III - Sorbonne Nouvelle, de setembro de 2010 a fevereiro de 2011, período durante o qual o doutorando esteve associado ao "Centre de Recherches sur les Pays Lusophones (Crepal
} 
composições lírico-amorosas, que citamos e comentamos, da Fuente de Aganipe, a pouco estudada obra poética de Manuel de Faria e Sousa.

Tendo sempre em vista nosso objetivo primordial de compreender melhor a poesia lírico-amorosa seiscentista seguindo os ornados labirintos de seu amor agudo, o terceiro capítulo da tese está voltado para a discussão de possíveis (e implícitos) “códigos de amor" ou "artes de amar" dessa poesia, ressaltando a importância tanto da lírica trovadoresca, cujas cantigas que a compõem são modelos relevantes para a lírica amorosa do século XVII, como da preceptiva do fin'amor, em especial do Tratactus de amore de André Capelão. Mais ainda, mostra-se que no som que ecoa na poesia amorosa seiscentista ouve-se também a "música" da lírica trovadoresca, conquanto se assente em princípios aristotélicos essa reverberação (menos sonora e mais conceitual) da produção poética medieval no século XVII, sendo a poesia, nesses anos Seiscentos, compreendida como imitação escrita, e não como música. Daí sugerir-se que a lírica seiscentista seja um "canto escrito".

Ainda no terceiro capítulo, continuamos a examinar a produção retóricopoética seiscentista guiando-nos pela imitação, à procura de outras fontes do amor agudo. Assim, damos destaque a uma autoridade poética que não pode ser ignorada quando se discutem os agudos poemas líricos, castelhanos e portugueses, do século XVII: Luis de Góngora. ${ }^{8}$ Ressaltamos a relevância do modelo gongórico, especialmente daquele da Fábula de Polifemo y Galatea e das Soledades, ao analisarmos, minuciosamente, um longo poema lírico (uma das diversas Saudades de Lidia e Armido que circulam no século XVII), composto por 158 oitavas e atribuído a Bernardo Vieira Ravasco, irmão do Padre Antônio Vieira. Tal atribuição é devida a Antônio Correia Vianna que, no século XVIII, fez diversas compilações manuscritas de poemas seiscentistas. Por se tratar de uma composição que muito contribui para as nossas discussões acerca do amor agudo e, além disso, por ser um poema inédito da pouco conhecida obra poética dita de Bernardo Ravasco, transcrevemos, como "anexo" da tese, essas Saudades de Lidia e Armido, com base no referido manuscrito de Correia Vianna, depositado na Biblioteca da Ajuda.

\footnotetext{
- EA 3421)", da "École Doctorale Europe Latine - Amérique Latine (ED 122)", sendo supervisionado pela Profa. Dra. Jacqueline Penjon, diretora do Crepal.

${ }^{8} \mathrm{O}$ trabalho de José Ares Montes, por exemplo, defende a tese de que é Góngora o principal modelo da poesia portuguesa do século XVII (Góngora y la Poesía Portuguesa del Siglo XVII. Madrid: Gredos, 1956). Dámaso Alonso também destaca a permanência do modelo gongórico na Espanha, em Portugal e na América espanhola, no "estudo preliminar" de sua edição da Fábula de Polifemo y Galatea (Góngora y el "Polifemo". Madrid: Gredos, 1967, pp.231-267).
} 
As discussões desenvolvidas nesses três capítulos conduzem às "considerações finais" do trabalho, nas quais procuramos mostrar, reunindo aquilo que espalhamos nessas três partes da tese, que de uma aguda poesia decorre a confecção de um amor igualmente agudo, isto é, como já mencionado, um amor que não é uma expressão subjetiva e original, mas que aparece em poemas cujos efeitos inesperados são retórica e poeticamente construídos. Fruto de imitações, esse agudo amor é ovidiano, cortês, petrarquista, camoniano, marinista, gongórico; miscelânea de doutrinas, é platônico, estoico, epicurista, cristão. Enfim, é o variado amor da aguda lírica amorosa seiscentista, engenhosa imitação de amores vários e imperfeito reflexo do amor divino. 


\section{Capítulo 1}

\section{A lírica seiscentista: gênero de cultivo do amor agudo}

A noção de amor agudo está integrada a um determinado gênero: a poesia lírica seiscentista. Nesse gênero se constitui aquela matéria, mas ele é também por ela constituído. Isso porque, na produção retórico-poética do século XVII, a adequação do assunto é um dos preceitos a serem seguidos na composição de um poema, fazendo com que os gêneros se diferenciem, entre outras coisas, pelas matérias diversas que lhes cabem tratar. Nesse sentido, como importante fonte para os tratados poéticos e retóricos dos anos Seiscentos, devemos lembrar que, segundo Aristóteles, "a epopeia, a tragédia, assim como a poesia ditirâmbica e a maior parte da auléitca e da citarística, todas são, em geral, imitações. Diferem, porém, umas das outras, por três aspectos: ou porque imitam por meios diversos, ou porque imitam objectos diveros, ou porque imitam por modos diversos e não da mesma maneira" (Poética, I, 1447a, 13-16). ${ }^{9}$ Portanto, distinguem-se as imitações poéticas também em função dos diferentes objetos imitados, sendo que a epopeia e a tragédia imitam homens superiores e a comédia, homens inferiores. Além disso, outra relevante distinção feita por Aristóteles, na Retórica, é aquela dos três gêneros de discurso: deliberativo, judicial e epidítico. O que nos interessa destacar, neste momento, é que entre os aspectos que diferenciam esses gêneros, é preciso atentar para a adequação dos assuntos ou matérias dos diversos discursos, já que eles têm diferentes fins: numa deliberação, deve-se aconselhar ou dissuadir, visando à conveniência ou inconveniência de eventos futuros; num discurso judicial, aquele que acusa ou defende tem em vista a justiça ou injustiça de fatos passados; e num discurso epidítico, cujo tempo principal é o presente, o elogio ou a censura põe em evidência o belo ou o feio. Assim, para atingir esses diversos fins é preciso que os assuntos tratados lhes sejam apropriados. Isso fica patente, por exemplo, quando Aristóteles começa a discutir o gênero deliberativo:

\footnotetext{
9 Edição utilizada: Aristóteles. Poética. Tradução, prefácio, introdução, comentário e apêndices de Eudoro de Sousa. $8^{\text {a }}$ edição. Lisboa: Imprensa Nacional - Casa da Moeda, 2008.
} 
Importa primeiramente compreender que coisas, boas ou más, aconselha o orador deliberativo, pois não se ocupa de todas as coisas, mas apenas das que podem vir a acontecer ou não. (...) Os temas mais importantes sobre os quais todos deliberam e sobre os quais os oradores deliberativos dão conselho em público são basicamente cinco, a saber: finanças, guerra e paz, defesa nacional, importações e exportações, e legislação (Retórica, I, 4, 1359a-1359b). ${ }^{10}$

Desse modo, a matéria tratada está intrinsecamente ligada ao gênero de um poema ou de um discurso, sendo fundamental essa adequação para a preceptiva retórico-poética seiscentista. Enfim, nas construções poéticas são também determinantes os materiais empregados.

Por isso, a compreensão do amor agudo deve assentar-se, necessariamente, na poesia lírica amorosa, já que aquele alicerce é essencial na construção desta poesia. $O$ gênero lírico, no entanto, é de difícil definição no século XVII, pois não conta com uma preceptiva poética específica e unívoca. Os preceitos que se referem à lírica estão dispersos em tratados poéticos e retóricos quinhentistas e seiscentistas, configurando uma escassez normativa bastante diversa da consistente preceptiva que trata da epopeia, da tragédia e da comédia. Se são escassas as normas do gênero lírico, os poemas ditos "líricos" abundam na produção poética dos séculos XVI e XVII que, vale salientar, é pautada justamente por procedimentos retóricos e poéticos.

Essa dificuldade dos preceptistas dos anos Quinhentos e Seiscentos em definir a poesia lírica talvez decorra da pouca atenção que as "autoridades" antigas dedicaram à discussão de tal gênero. A já citada Poética de Aristóteles, por exemplo, - que, como se sabe, foi uma fonte muito traduzida, comentada e imitada a partir de meados do século XVI - não se detém na análise da lírica, e esse modelo aristotélico se reflete nos tratados poéticos quinhentistas e seiscentistas que, na sua maioria, discutem longamente a epopeia, a tragédia e, em menor medida, a comédia, mas pouco se voltam para a poesia lírica. No entanto, isso não significa que aspectos do gênero lírico não sejam debatidos em tratados, prólogos, comentários e nos próprios poemas; e esse debate sobre elementos específicos da lírica vai se intensificando no decorrer dos anos Seiscentos. É preciso ressaltar, porém, que aquilo que entendemos hoje por "gênero lírico" não

\footnotetext{
${ }^{10}$ Edição utilizada: Retórica. Tradução e notas de Manuel Alexandre Júnior, Paulo Farmhouse Alberto e Abel do Nascimento Pena. Lisboa: Imprensa Nacional - Casa da Moeda, 1998.
} 
corresponde às diversas espécies líricas da produção retórico-poética do século XVII. Como afirma Maria do Socorro Fernandes de Carvalho, a eminência poética e a univocidade daquele gênero são posteriores a esta produção:

À vista do poema épico, arrematado e revitalizado no século XVI por Luís de Camões, e dos grandes modelos da tragédia e da comédia, os tratados seiscentistas de poética não reconheciam as diversas formas líricas como um gênero unívoco, ainda que abrangente. Aliás, a abrangência do gênero lírico conforme a temos hoje somente seria concebida posteriormente, no contexto propiciado pela poesia romântica, que alçou à lírica a chancela da eminência poética conforme a temos nos nossos dias. ${ }^{11}$

É também romântica a concepção de uma poesia lírica amorosa centrada na expressão subjetiva do poeta; concepção essa que não condiz com a lírica seiscentista, produzida sobre bases retóricas e poéticas, seguindo, portanto, preceitos, atendendo à verossimilhança e ao decoro, não sendo expressão subjetiva e original de indivíduo algum e apresentando poemas cujos efeitos são racionalmente construídos. ${ }^{12}$

A apreciação desses poemas [seiscentistas] pressupõe a clara noção de que não se trata de poesia amorosa no sentido romântico, em que o indivíduo simula ou supõe viver uma paixão, construindo a emotividade como parte imprescindível do enunciado poético. Trata-se, ao contrário, de poemas celebrativos, em que a encenação do elogio integra um todo conceitual, em que cada parte apresenta aspecto ou diferente prisma de um gênero retórico do discurso, jamais esquecido pelo poeta e do qual sempre deve se lembrar o leitor. ${ }^{13}$

Desse modo, parece mais pertinente tentar buscar na própria res literaria ${ }^{14}$ seiscentista elementos que nos permitam vislumbrar como era compreendida a poesia

\footnotetext{
${ }^{11}$ Carvalho, M.S.F. de. Poesia de agudeza em Portugal, op.cit., p.180.

${ }^{12}$ Cf. Hansen, J. A. "Fênix renascida \& Postilhão de Apolo: Uma introdução", op.cit., p.48.

${ }^{13}$ Teixeira, I. "A poesia aguda do engenhoso fidalgo Manuel Botelho de Oliveira". In: Música do Parnaso. Cotia: Ateliê Editorial, 2005, pp.20-21.

${ }^{14}$ Ao utilizarmos esse termo, remetemo-nos às discussões de Marc Fumaroli sobre as noções de "retórica", "res literaria" e "literatura", em seu livro L'âge de l'éloquence: rhétorique et "res literaria" de la Renaissance au seuil de l'époque classique. Podemos citar, em especial, os seguintes trechos: "Il s'agit en somme de voir la culture rhétorique du XVII ${ }^{\mathrm{e}}$ siècle non plus à travers un concept de 'littérature'
} 
lírica no século XVII. Para tanto, é necessário também reconhecer e analisar os modelos dessa produção retórico-poética dos anos Seiscentos, desde os quinhentistas até os antigos. Esse trabalho de examinar as especificidades do gênero lírico no século XVII, especialmente com base na poesia produzida em Portugal (que também é objeto central de nosso estudo), foi feito, minuciosamente, por Maria do Socorro Fernandes de Carvalho, em seu já citado estudo sobre a Poesia de Agudeza em Portugal (todo o capítulo 3 é dedicado à análise do "gênero lírico e estilo mediano"). ${ }^{15}$ Tomando esse estudo como ponto de partida, vale mencionar a caracterização inicial que a autora fez da poesia lírica seiscentista:

Em suma, face à grandeza épica, a lírica cultivada apresenta certa tentativa de fazer permanecer na diversidade, brevidade e mescla de estilos que lhe é característica, a abrangência, a elevação elocutiva e o prestígio da memorável poesia greco-latina. Em Portugal, depois do sucesso estupendo d'Os Lusíadas e das várias tentativas épicas mais ou menos bem sucedidas durante a primeira metade do século XVII, a poesia é toda afetada pela lírica. Mas esta terá critérios próprios de excelência, que vão conferir grandeza aos poemas. O que importa para o estudo da poesia portuguesa do século XVII é o desenvolvimento que essas tipologias proveram à fixação dos gêneros da lírica, conjunto de poemas de pequena e média extensão, que apresentam modos diversos de enunciação, comungando a voz poética ora quando o poeta fala sempre, ora quando o poeta fala às vezes, e até o modo ativo de personagens que falam por si, seguindo-se a divisão aristotélica dada a esse item enunciativo e sendo considerada por esse aspecto um gênero de enunciação mista. Assim, lírica no século XVII significa, de antemão, poesia de amenidade e sonoridade, dedicada à imitação das paixões; do ponto de vista formal, trata-se de verso marcado pela sonoridade, pela alteração entre sílabas longas e breves e por conduzir em si todo o sentido do período verbal, sem deixar o significado da sentença depender da linha métrica seguinte. ${ }^{16}$

élaboré tardivement, mais à l'aide de ses propes critères, et des débats dont ils étaient l'objet en leur temps" (L'âge de l'éloquence. Paris: Albin Michel, 1996, p.20); e "Âge de l'Éloquence, âge de la rhétorique, le XVII ${ }^{\mathrm{e}}$ siècle voit naître les Belles-Lettres : il n'est pas encore l'âge de la littérature" (Idem, p.31).

${ }_{15}$ Carvalho, M.S.F. de. Poesia de agudeza em Portugal, op.cit., pp.171-259.

${ }^{16}$ Idem, pp.174-175. 
As discussões apresentadas pela estudiosa desenvolvem essas (e outras) características do gênero lírico no século XVII, tendo como objetivo, segundo suas próprias palavras, oferecer "uma proposta de conceituação abrangente da lírica seiscentista". ${ }^{17}$ Essa "conceituação abrangente" é fundamental para o nosso trabalho, embora tenhamos um objetivo principal mais específico: o debate sobre o gênero lírico é um primeiro campo onde pretendemos colher elementos para a caracterização do amor da variada lírica seiscentista. Além disso, de nada serviria somente reproduzir aquilo que já está tão bem feito. Dessa forma, aproveitaremos o que foi discutido para desenvolver outros aspectos desse gênero, visando sempre à nossa finalidade de analisar as especificidades da lírica amorosa dos anos Seiscentos. Referimo-nos a essa espécie lírica, que tem como matéria central o amor, pautando-nos pela prescrição horaciana dos assuntos adequados à "lira": "a Musa concedeu à lira o cantar deuses e filhos de deuses; o vencedor no pugilato e o cavalo que, primeiro, cortou a meta nas corridas; os cuidados dos jovens e o vinho que liberta dos cuidados". ${ }^{18}$ Portanto, como sintetiza Adma Muhana embasando-se em Horácio, "a lírica se destina, como norma, a cantar seja a beleza, o bem amoroso, a amada, seja os homens virtuosos cujos feitos são dignos de se guardar na memória". ${ }^{19}$ Nosso foco, como já apontado, é uma parte específica dessa divisão horaciana: a lírica amorosa. Mais precisamente, visamos aos poemas líricos que glosam as tópicas amorosas mais recorrentes na poesia seiscentista, tais como o bem e o mal (ou desengano) de amor, a beleza da amada, a dor do tempo, o ideal inatingível, a abnegação do amante etc.

Todavia, um primeiro problema que se impõe para o desenvolvimento de nosso trabalho é identificar os elementos, na leitura dos poemas, que nos permitam afirmar que se trata de poesia lírica, segundo os critérios do século XVII. Essa dificuldade de explicar por que certos poemas são "líricos" decorre, principalmente, do fato, já mencionado, de não ser consistente, nos anos Quinhentos e Seiscentos, a preceptiva poética específica sobre o gênero lírico, tornando complicada, assim, uma discussão técnica acerca dos aspectos peculiares à lírica.

\footnotetext{
${ }^{17}$ Idem, p. 175 .

18 "Musa dedit fidibus diuos puerosque deorum / et pugilem uictorem et equum certamine primum / et iuuenum curas et libera uina referre" (Epistola ad Pisones, vv.83-85). Edição utilizada: Arte Poética. Introdução, tradução e comentários de R. M. Rosado Fernandes. Lisboa: LCE, s/d (coleção bilíngüe).

${ }^{19}$ Muhana, A. "Introdução". In: Oliveira, M. B. de. Poesia completa: Música do Parnasso, Lira Sacra. Introdução, organização e fixação de texto Adma Muhana. São Paulo: Martins Fontes, 2005, p. XXXVIII.
} 
Para tentar contornar tal dificuldade, uma alternativa é partir da leitura de um soneto atribuído ${ }^{20}$ a um poeta tido como uma das principais autoridades da poesia lírica portuguesa do século XVII, Antônio Barbosa Bacelar, ${ }^{21}$ questionando-nos sobre os motivos de poder ser esse poema ${ }^{22}$ considerado lírico. O soneto em questão ("Amoroso desdém num belo agrado") encontra-se reproduzido em diversos manuscritos seiscentistas e setecentistas, bem como na Fênix Renascida, além de ser presença constante em coletâneas de poesia portuguesa do século XVII editadas recentemente. ${ }^{23}$

Amoroso desdém num belo agrado

No mais duro ferir um doce jeito,

Tirania suave em brando aspeito,

Olhos de fogo em coração nevado.

No vestir um asseio discuidado,

Ingratidão amável no respeito,

$\mathrm{O}$ brio, a graça, o riso em um sujeito,

\footnotetext{
${ }^{20}$ Esse nosso cuidado de explicitar que grande parte das obras de importantes poetas seiscentistas é fruto de atribuições (às vezes, questionáveis) tem por objetivo deixar claro que estamos lidando com uma constante incerteza de autoria e datação dos poemas. Para tentar contornar esse obstáculo, proporemos, a partir de fontes retóricas e poéticas e de trabalhos de outros pesquisadores, o emprego da noção de auctoritas (ou "autoridade"); noção essa que será devidamente explicada ainda neste capítulo de nosso estudo.

${ }^{21}$ Bacelar é um poeta que quase sempre tem lugar de destaque nos estudos e nas coletâneas de poesia seiscentista portuguesa, além de ter sido tema central de artigos e trabalhos acadêmicos. Para exemplificar, podemos mencionar a dissertação de Maria de Lourdes dos Santos Cunha, intitulada $A$ Poética de António Barbosa Bacelar (Dissertação para Licenciatura em Filologia Românica apresentada à Faculdade de Letras da Universidade de Lisboa, 1961), a dissertação de Maria do Céu Brás da Fonseca, Uma Leitura de Camões por António Barbosa Bacelar. Edição de Sonetos (Dissertação de Mestrado em Literatura Portuguesa apresentada à Faculdade de Letras da Universidade de Lisboa, 1992) e a excelente edição das Obras poéticas de António Barbosa Bacelar (1610-1663), preparada e apresentada por Mafalda Ferin Cunha (Lisboa: Fundação Calouste Gulbenkian, 2007).

${ }^{22}$ Cabe reproduzir aqui a pertinente ressalva feita por Maria do Socorro Fernandes de Carvalho sobre a utilização do termo "poema" nos anos Seiscentos: "à falta de um termo específico e aglutinador na terminologia poética antiga, 'poema' passa a designar também as espécies da lírica" (Poesia de agudeza em Portugal, op.cit., p.181).

${ }^{23}$ As referências completas de manuscritos nos quais esse soneto está reproduzido - na maior parte das vezes dito de Bacelar, mas aparecendo também como anônimo - podem ser encontradas na edição, já citada, de poemas atribuídos ao poeta, feita por Mafalda Ferin Cunha (Obras Poéticas de António Barbosa Bacelar, op.cit., p.518). Além disso, como afirmamos, esse poema também faz parte da Fênix Renascida, em suas duas edições (A Fenix Renascida ou obras poeticas dos melhores engenhos portuguezes. Publica-o Mathias Pereira da Sylva. - Lisboa Occidental: na Officina de Antonio Pedrozo Galrão, 1716-1728, tomo IV, p.284; e A Fenix Renascida ou obras poeticas dos melhores engenhos portuguezes. Segunda vez impresso e acrescentado por Mathias Pereira da Sylva. Lisboa: Offic. dos Herd. de Antonio Pedrozo Galram, 1746, tomo IV, p.308). Finalmente, apenas como exemplo da importância do soneto em questão para as coletâneas (nossas) contemporâneas de poesia seiscentista, pode-se mencionar duas das mais recentes: Poetas do período barroco. Apresentação, seleção e notas de Maria Lucília Gonçalves Pires. Lisboa: Comunicação, 1985, pp.131-132; Poesia seiscentista - Fênix Renascida \& Postilhão de Apolo. Organização de Alcir Pécora; Introdução de João Adolfo Hansen. São Paulo: Hedra, 2002, p.157.
} 
Variamente com o grave misturado.

Animado primor da fermosura,

Luzido discursar de engenho agudo,

Custosa luz, incêndio pertendido.

Alma no talhe, garbo na postura,

Capricho no cuidado, ar no discuido,

Armas são com que Amor me tem rendido. ${ }^{24}$

O questionamento sobre o gênero em que se insere esse soneto leva a uma resposta, supostamente, simples: trata-se de um poema lírico, mais especificamente, lírico-amoroso. No entanto, desenvolver tal afirmação e explicá-la segundo os procedimentos retórico-poéticos que norteiam a poesia do século XVII é algo bastante complexo, ainda mais se levarmos em conta que os próprios preceptistas e poetas seiscentistas não normatizaram o gênero lírico a ponto de lhe darem contornos nítidos e precisos. Como no caso do soneto transcrito acima, não é apenas porque um poema apresenta uma temática amorosa, mencionando, inclusive, o "amor", ou ainda porque sua persona lírica ${ }^{25}$ fala em voz própria, utilizando a primeira pessoa do singular, que estará resolvida a questão de seu caráter lírico. Se se objetiva uma análise mais consistente e apropriada à produção retórico-poética dos anos Seiscentos, é preciso discutir diversos aspectos inventivos, dispositivos e elocutivos que enformam as composições poéticas da época, já que os tratados seiscentistas, como, por exemplo, a Arte Poética (1615) de Filipe Nunes, seguem os antigos e ensinam que a poesia

Em tres partes se diuide. Em inuenção, disposição, \& ellocução. Cõ a inuenção busquamos a materia, a qual podera ser verdadeira, ou aparente, \& que não contradiga ao entendimento, ainda que seja fingida. Com a disposição se ordena a forma, concertando \& dispondo o estilo $\&$ a materia que se tiuer ja buscada, no verso que melhor parecer, \& for mais conueniente. Com a ellocução se alcança o fim de que forçadamente ha de constar qualquer composto. ${ }^{26}$

\footnotetext{
${ }^{24}$ Citamos o texto da edição de Mafalda Ferin Cunha: Obras poéticas de António Barbosa Bacelar, op.cit., p.518.

${ }^{25}$ Preferimos o termo "persona lírica" a "poeta", "autor", "eu-lírico", "sujeito lírico", "sujeito poético" etc., por diversos motivos que serão explicitados ao longo do nosso trabalho.

${ }^{26}$ Nunes, Philippe. Arte Poetica, e da Pintura, y Simmetrya, com principios da perspectiva. Lisboa: por Pedro Crasbeeck, 1615.
} 
$\mathrm{Na}$ leitura de "Amoroso desdém num belo agrado", é possível notar sua semelhança com o soneto "Um mover de olhos, brando e piedoso", atribuído a Camões. Aliás, essa é uma característica marcante que não se restringe a esse poema: muitas outras composições reunidas sob o nome de Antônio Barbosa Bacelar ecoam a obra lírica dita de Camões, que (talvez seja desnecessário lembrar) foi um dos mais importantes modelos para os poetas seiscentistas portugueses, funcionando como uma auctoritas quinhentista tanto da poesia épica como da lírica. Essa proximidade dos poemas amorosos atribuídos a Bacelar com aqueles que circulam sob a autoridade do "Camões Lírico" não é uma questão de personalidade, de estilo ou de inspiração (termos inaplicáveis a esses textos e autoridades), mas sim um procedimento retórico-poético pelo qual se pauta a poesia seiscentista: a imitação. Vale a pena, então, também transcrever o modelo camoniano do soneto seiscentista que o imita.

Um mover de olhos, brando e piedoso,

Sem ver de quê; um riso brando e honesto,

Quase forçado; um doce e humilde gesto,

De qualquer alegria duvidoso;

Um despejo quieto e vergonhoso;

Um repouso gravíssimo e honesto;

Ũa pura bondade, manifesto

Indício da alma, limpo e gracioso;

Um encolhido ousar; ũa brandura;

Um medo sem ter culpa; um ar sereno;

Um longo e obediente sofrimento:

Esta foi a celeste fermosura

Da minha Circe, e o mágico veneno

Que pôde transformar meu pensamento. ${ }^{27}$

Ana Hatherly fez uma análise comparativa desses dois sonetos transcritos em um artigo intitulado Reescrita e Inovação Barroca: António Barbosa Bacelar vs. Luís de Camões. ${ }^{28}$ No entanto, já no título de seu texto fica claro que sua perspectiva não é a

\footnotetext{
${ }^{27}$ Camões, L. de. Obra Completa. Organização, introdução, comentários e anotações de Antônio Salgado Júnior. Rio de Janeiro: Nova Aguilar, 2005, p.301.

${ }^{28}$ In: Estudos portugueses: homenagem a António José Saraiva. Lisboa: Ministério da Educação, Instituto de Cultura e Língua Portuguesa; Faculdade de Letras da Universidade de Lisboa, 1990, pp.3146.
} 
que seguimos, pois nos parece que "reescrita" e "inovação" são termos inadequados para se analisar uma poesia regida por preceitos retórico-poéticos que fazem dela uma poesia imitativa, e não inovadora ou original.

Assim, ao ler ou ouvir o poema atribuído a Bacelar, os leitores ou ouvintes da época (em especial aqueles que tinham certa erudição poética) reconheciam o modelo camoniano, observando as diferenças e julgando se a imitação foi bem sucedida ou não, isto é, se o soneto seiscentista segue seu modelo quinhentista, obedecendo aos preceitos do gênero lírico e da espécie métrica, sem ser, contudo, uma mera cópia ou imitação servil. Para surpreender ainda mais esses leitores ou ouvintes, habituados a composições engenhosas e agudas, o poema atribuído a Bacelar encerra-se com um verso que ecoa outro soneto da lírica camoniana: "Leda serenidade deleitosa" ${ }^{29}$ Nessa composição dita de Camões, lemos as seguintes palavras: "Estas as armas são com que me rende / E me cativa Amor", fonte evidente do verso “Armas são com que Amor me tem rendido", que encerra o soneto dito de Bacelar. Esse remate inesperado busca deleitar os ouvintes ou leitores para que eles, familiarizados com os procedimentos retórico-poéticos seiscentistas, tenham mais um motivo para considerar o poema uma imitação engenhosa e aguda.

Vale ressaltar, além disso, que o soneto "Um mover de olhos, brando $e$ piedoso" também tem um evidente modelo: "Grazie ch'a pochi il ciel largo destina", da lírica petrarquista. ${ }^{30}$ Essas sucessivas imitações norteiam a poesia dos séculos XVI e XVII, construída a partir das technai retórica e poética. Os poetas seiscentistas imitam as auctoritates, fontes de excelência do gênero em que compõem. Por isso, o soneto atribuído a Bacelar nos remete a Camões que, por sua vez, evoca Petrarca: autoridades da lírica que se constituem de imitação em imitação.

\footnotetext{
29 "Leda serenidade deleitosa, / Que representa em terra um paraíso; / Entre rubis e perlas, doce riso; / Deba[i]xo de ouro e neve, cor-de-rosa; / Presença moderada e graciosa, / Onde ensinando estão despejo e siso / Que se pode por arte e por aviso, / Como por natureza, ser fermosa; / Fala de quem a morte e a vida pende, / Rara, suave, enfim, Senhora, vossa; / Repouso, nela, alegre e comedido: / Estas as armas são com que me rende / E me cativa Amor; mas não que possa / Despojar-me da glória de rendido." (Camões, L. de. Obra Completa, op.cit., p.282).

30 "Gratie ch'a pochi il ciel largo destina: / rara vertú, non già d'umana gente, / sotto biondi capei canuta mente, / e 'n humil donna alta beltà divina; / leggiadria singulare et pellegrina, / e 'l cantar che ne l'anima si sente, / l'andar celeste, e 'l vago spirto ardente, / ch'ogni dur rompe et ogni altezza inchina; / et que' belli occhi che i cor' fanno smalti, / possenti a rischiarar abisso et notti, / et tôrre l'alme a' corpi, et darle altrui; / col dir pien d'intellecti dolci et alti, / coi sospiri soave-mente rotti : / da questi magi transformato fui.” (Petrarca, F. Canzoniere. Torino: Einaudi, 1992, p.274).
} 
Para compreendermos melhor em que consiste essa prática mimética pela qual se norteia a produção retórico-poética ${ }^{31}$ dos séculos XVI e XVII, devemos recordar, inicialmente, que, segundo Aristóteles, a poesia é mimesis que ensina e deleita os homens:

A epopéia, a tragédia, assim como a poesia ditirâmbica e a maior parte da aulética e da citarística, todas são, em geral, imitações. (...) Ao que parece, duas causas, e ambas naturais, geraram a poesia. O imitar é congénito no homem (e nisto difere dos outros viventes, pois, de todos, é ele o mais imitador, e, por imitação, apreende as primeiras noções), e os homens se comprazem no imitado (Poética, I, 1447a, 13-15; IV, $1448 b, 4-8)$.

Na Poética aristotélica, a mimesis é a causa primeira da poesia, e é justamente devido à imitação, algo que distingue os seres humanos dos demais animais, que é possível aos homens conhecer as coisas. "Relacionando o conhecer ao ato de imitar, então, a Poética dignifica a poesia e o prazer que dela advém. Prazer no aprender pela semelhança, pois imitar é conhecer o que se faz". ${ }^{32}$ Por isso, imitar é fazer como a natureza faz, conhecendo suas causas e identificando suas analogias. O poeta, diferentemente do historiador, não narra o que aconteceu, mas o que poderia acontecer, aquilo que é possível segundo a verossimilhança e a necessidade (Poética, IX, 1451a, 36-39). O que rege a imitação poética, portanto, é a verossimilhança (um fazer como) e não a "verdade" (um fazer igual), pois "de preferir às coisas possíveis mas incríveis, são as impossíveis mas críveis" (Poética, XXIV, 1460a, 26-27).

Se, no tratado de Aristóteles, mimesis é noção fundamental para se compreender a poesia, nos tratados poéticos e retóricos posteriores à Poética, a imitação

\footnotetext{
${ }^{31}$ Vale ressaltar, neste momento, um importante pressuposto de nossas considerações: tanto para os autores antigos como para os quinhentistas e seiscentistas, as relações entre as artes retórica e poética são muito estreitas. Como esclarece Heinrich Lausberg, "la relación de la poética con la retórica es (...) muy íntima: el terreno común para el poeta que compone y para el orador que ejerce es la mutua compenetración de ambas artes en los artistas creadores"; ou ainda: "la ilimitación objetiva de la retórica permite transferir todas sus técnicas a la poesía" (Manual de Retórica Literaria. Versión española de José Pérez Riesco. Tomo I. Madrid: Gredos, 1975, p.89). Um preceptista português do século XVII, Manuel Pires de Almeida, escreve algo nesse mesmo sentido: "e advirto, que tenho impossível ser poeta sem o conhecimento da Retórica" (Discurso sobre o Poema Heróico. Manuscrito redigido por volta de 1633 e atualmente depositado no Arquivo Nacional da Torre do Tombo, em Lisboa. Foi publicado por Adma Muhana: REEL - Revista Eletrônica de Estudos Literários, Vitória, a.2, n.2, 2006, pp.1-22. Disponível em: http://www.ufes.br/ mlb/reel2/ AdmaMuhana. pdf).

${ }^{32}$ Muhana, Adma. "Causas da poesia na Poética". In: Phaos - Revista de Estudos Clássicos, Campinas, v.4, 2004, p.99.
} 
continua a ser um tema amplamente debatido. Essas discussões, ainda que decorrentes dos preceitos aristotélicos, apresentam outras perspectivas e centram-se em dois aspectos: a imitação da natureza (as coisas imitadas) e dos melhores autores (as autoridades). Embora, muitas vezes, esses dois aspectos se confundam, para não perdermos o foco do nosso trabalho, interessa-nos, neste momento, pensar mais no segundo, ou seja, na importância dos modelos. Nesse sentido, devemos ter em mente que imitar as auctoritates, pelo menos até o começo do século XVIII, significa um estudo dos bons modelos ${ }^{33}$ e uma seleção do que há de melhor em cada um deles, visando à composição de uma obra que atenda às especificidades do gênero no qual se insere. Nessa concepção retórico-poética de imitação, não cabe a nossa noção contemporânea de "plágio"; o que se recrimina nos tratados retóricos e poéticos é a cópia ou imitação servil, como lemos na Arte Poética de Horácio: "Matéria a todos pertencente será tua legítima pertença, se não ficares a andar à volta no caminho trivial, aberto a todos, e tão-pouco procurarás, como servil intérprete, traduzir palavra por palavra, nem entrarás, como imitador, em quadro muito estreito de onde te impedirão de sair a timidez e a economia da obra". ${ }^{34}$

Quintiliano também censura aqueles que simplesmente copiam aquilo que já foi feito, sem inventar nada de novo, já que tal imitação servil não é o suficiente:

Ante omnia igitur imitatio per se ipsa non sufficit, vel quia pigri est ingenii contentum esse iis quae sint ab aliis inventa. Quid enim futurum erat temporibus illis, quae sine exemplo fuerunt, si homines nihil, nisi quod jam cognovissent, faciendum sibi aut cogitandum putassent? Nempe nihil fuisse inventum (Inst. Orat., X, II, 4). ${ }^{35}$

Essa disputa com os antigos nos remete ao "afeto" (pathos) que Aristóteles definiu como emulação: "consiste num certo mal-estar ocasionado pela presença

\footnotetext{
${ }^{33}$ Horácio, por exemplo, recomenda aos Pisões que compulsem dia e noite os "exemplares" gregos: "Vos exemplaria Graeca / nocturna uersate manu, uersate diurna" (Epistola ad Pisones, vv.268-269).

34 "Publica materies priuati iuris erit, si / non circa uilem patulumque moraberis orbem, / nec uerbo, uerbum curabis reddere fidus / interpres nec desilies imitator in artum, / unde pedem proferre pudor uetet aut operis lex" (Epistola ad Pisones, vv.131-135). É o que também afirma Cícero, recriminando qualquer cópia servil que imite somente as coisas mais fáceis ou os defeitos: "multos imitatores saepe cognoui, qui aut ea, quae facilia sunt, aut etiam illa, quae insignia ac paene uitiosa, consectentur imitando. Nihil est facilius quam amictum imitari alicuius aut statum aut motum" (De Oratore, II, 90-91). Edição utilizada: De l'orateur. Texte établi et traduit par Edmond Courbaud. Paris : Les Belles Lettres, 1950.

${ }^{35}$ Edição utilizada: Quintiliano. Institution Oratoire. Texte établi et traduit par Jean Cousin. Paris: Les Belles Lettres, 1975-1980.
} 
manifesta de bens honoríficos e que se podem obter em disputa com quem é nosso igual por natureza, não porque tais bens pertençam a outrem, mas porque também não nos pertencem (...) é forçoso admitir, então, que émulos são aqueles que se julgam dignos de bens que não têm mas que lhes seria possível vir a conseguir, uma vez que ninguém ambiciona aquilo que lhe é manifestamente impossível” (Retórica, II, 11, 1388a 1388b). Porém, é preciso ressaltar que, se a emulação é um "afeto" que provoca uma disputa entre iguais, a imitação é o procedimento por meio do qual o orador ou o poeta tenta igualar e, por vezes, superar seus modelos.

Dionísio de Halicarnasso, no Tratado da Imitação, relata dois exempla que sintetizam muito bem de que forma deve se dar essa prática mimética. No primeiro, conta-se a história de um camponês que, por ser muito feio, tinha medo de ter filhos semelhantes a ele. Para evitar que isso ocorresse, juntou várias imagens belas e acostumou a mulher a contemplá-las. Desse modo, quando se uniu a ela, conseguiu gerar a beleza das imagens e ter filhos bonitos. O outro exemplum é o do pintor Zêuxis de Crotona, que para pintar Helena desnuda viu, nuas, as moças da cidade, com o intuito de reunir o que havia de mais belo nelas na figuração de um só corpo. Depois de relatar esses “exemplos”, Dionísio de Halicarnasso conclui ensinando o leitor:

\begin{abstract}
Assim, a partir da seleção de várias partes, a arte realizou uma forma única, perfeita e bela. Também tu, da mesma maneira, tens a possibilidade de procurar no teatro formas de antigos corpos, de colher o melhor do seu espírito e, ao juntares a tudo isto o dom da erudição, de modelar não uma figura que se desgasta com o tempo, mas sim a beleza imortal da arte (Tratado da Imitação, II, 6). ${ }^{36}$
\end{abstract}

Seguindo a preceptiva antiga da imitação, López Pinciano, em fins do século XVI, afirma, na "terceira epístola" de sua Philosophía Antigua Poética, que a poesia é arte que ensina a imitar com a língua e o poema é imitação feita com a dita língua ou linguagem. Além disso, esclarece que o "imitar", que é o mesmo que "remendar" ou “contrafazer", está presente tanto nas obras da natureza quanto nas obras da arte; e o que a natureza e a arte fazem, quando remendam as obras de outros, é dito imitação.

\footnotetext{
${ }^{36}$ Edição utilizada: Halicarnasso, Dionísio de. Tratado da Imitação. Edição e tradução de Raul Miguel Rosado Fernandes. Lisboa: Instituto Nacional de Investigação Científica; Centro de Estudos Clássicos das Universidades de Lisboa, 1986.
} 
Así que poesía no es otra cosa que arte que enseña a imitar con la lengua y poema es imitación hecha con la dicha lengua o lenguaje. Y porque este vocablo «imitar» podría poner alguna escuridad, digo que imitar, remedar y contrahacer es una misma cosa y que la dicha imitación, remedamiento y contrahechura es derramada en las obras de naturaleza y de arte. Ejemplo de la naturaleza es el niño que, apenas deja vacío el seno de la madre, y ya comienza a imitar: si reís, ríe; si lloraís, llora; si cantaís, canta; si cerraís el ojo, le cierra; si amenazáis, amenaza. Y ya mayor, si jugáis pelota, juega pelota; si pala, pala; si hacéis processión o disciplina, él hace processión y se disciplina; y otras infinitas monerías. Mas éstas basten por ejemplo de naturaleza. Y de la imitación que hace la arte, está lleno el mundo. Pregunto: ¿Qué hace el zapatero, sastre, bonetero, calcetero, sino imitar y remedar al pie, pierna, cuerpo y cabeza del hombre?, ¿qué el armero, sino lo que todos estos cuatro? y ¿qué el pintor, sino lo que todos cinco y mucho más?, ¿qué el médico, sino imitar a la naturaleza, cuando bien ejercita su obra? y ¿qué el gobernador, cuando con hartura, justicia y paz, rige y gobierna su tierra, sino imitar al summo Gobernador, el cual, con su infinita bondad, harta al mundo de pan, paz y justicia? Esto, pues, que la naturaleza y arte obran, cuando remeda a las obras de otros; esto, digo, es dicho imitación. ${ }^{37}$

É também imitação "cuando un autor toma de otra alguna cosa y la pone en la obra que él hace". ${ }^{38}$ Todavia, numa não explicitada referência à concepção platônica de imitação, ressalta-se que o autor que remenda a natureza é como um retratista (retratador) e aquele que remenda o que remendou a natureza é um simples pintor. Por isso, o poema que remenda a natureza e a arte é como um retrato, e o que remendou o retrato é como uma simples pintura. Portanto, mais primor tem a invenção e primeira imitação do poeta do que a segunda. Algumas vezes, porém, a simples pintura vence o retrato, dependendo da qualidade do pintor e do pincel. Virgílio e Horácio, por exemplo, têm "pinturas" que sobrepujam o "retrato" e imitações que vencem o inventor e não por isso deixaram de ser imitadores, pois não imitaram servilmente, tendo Horácio,

\footnotetext{
${ }^{37}$ Pinciano, A. L. Philosophía Antigua Poética. Obras completas, I. Edición de José Rico Verdú. Madrid: Biblioteca Castro, 1998, pp.110-111.

${ }^{38}$ Idem, p.111.
} 
inclusive, recriminado os imitadores, ou melhor, os "servos" que fazem parte do "rebanho servil":

Virgilio tiene pinturas que soprepujan al retrato, y imitaciones que vencieron al inventor, porque dejó en cosas a la pintura y siguió a la naturaleza misma. Y si los que imitan, de tal manera imitassen, no sería mucho vituperio, antes grande hazaña y digna de loor; mas no sé yo para qué fin imitaré yo mal lo que otro escribió y inventó bien. ¡No lo puedo sufrir! Ni aun Horacio sufrirlo pudo, el cual dice, destos tales imitadores, que son «rebaño siervo» que no tienen ingenio libre para inventar, y siervo que estraga lo que otro hizo bien. Y desta manera se ha de entender Horacio, el cual también fue imitador de otros, mas no siervo, porque imitó muy bien. ${ }^{39}$

Desse modo, imitar bem é não ser um imitador servil que simplesmente reproduza aquilo que já foi bem feito por outros. Como ensina Emanuele Tesauro, a imitação não é um exercício servil que vise à mera reprodução da coisa imitada, e sim uma sagacidade com a qual, quando se está diante de uma metáfora ou outra flor do engenho humano, deve considerar-se atentamente suas raízes e, transplantando-as em diferentes categorias como em solo cultivado e fecundo, propagar outras flores da mesma espécie, mas não os mesmos indivíduos: "Chiamo io dunque imitatione, una sagacità, con cui proposti una Metafora, ò altro fiore dell'humano ingegno; tu attentamente consideri le sue radici, e traspiantandole in differenti Categoríe, come in suolo sativo \& fecondo; ne propaghi altri fiori della medisima spetie; ma non gli medisimi Individui". 40

Na sua Nova Arte de Conceitos, que apesar de ser uma obra publicada no século XVIII, sistematiza a preceptiva retórico-poética da poesia seiscentista em Portugal, baseando-se, sobretudo, em Gracián e Tesauro, ${ }^{41}$ Francisco Leitão Ferreira discorre longamente sobre a imitação, dedicando as lições sétima e oitava de seu tratado a esse tema. Fazendo uma explícita referência à Poética de Aristóteles, Leitão Ferreira afirma que "tudo em fim teve principio na imitação, pelo que se lhe deve chamar mestra dos mestres, \& arte de todas as artes; assim porque a natureza infundio a imitação nos

\footnotetext{
${ }^{39}$ Idem, p.112.

${ }^{40}$ Tesauro, Emanuele. Il Cannocchiale Aristotelico (1654). Torino: Per Battolomeo Zavatta, 1670, p.116.

${ }^{41}$ Sobre a Nova Arte de Conceitos de Leitão Ferreira, veja-se Retórica e teorização literária em Portugal, de Aníbal Pinto de Castro (Lisboa: Imprensa Nacional-Casa da Moeda, 2008, pp.143-227).
} 
homẽs, como porque imitando se adquirem as primeyras regras das doutrinas"; ${ }^{42} \mathrm{e}$ define a imitação com as seguintes palavras:

Definimos a Imitação com Rodulfo Goclenio: Expressão parecida ao exemplar: de modo que o imitador, ha de não só imitar o caracter commum, mas tambem o particular do objecto, que imita: chamo caracter commum, à ideia, \& semelhança generica do exemplar; \& caracter particular, à ideia, \& semelhança de estylo do Author, ou Artifice imitado. $^{43}$

Há, portanto, duas imitações, que decorrem de duas semelhanças a serem observadas: genérica ou comum (da obra) e específica ou de estilo (do autor); a partir dessas imitações, deve, então, o imitador formar duas ideias que, copiadas, unidas e exprimidas na sua obra, constituirão a imitação perfeita. Contudo, Leitão Ferreira diferencia a imitação livre da imitação servil: "chamo Imitação livre, àquella em que o imitador independente de outro exemplar, imita a sua mesma ideia, como invento proprio. (...) Chamo porém Imitação servil àquella em que o imitador dependente do exemplar alheyo, o vay fielmente seguindo, \& copiando, sem já mais se apartar de suas linhas, nem desmentir hum passo de suas cores, como faz o aprendiz que copea a pintura de seu mestre". Embora a imitação livre seja mais valorizada do que a servil, esta última é também necessária e útil, pois assim como os homens têm o apetite natural pelo saber, eles têm o desejo natural de imitar e a imitação, ainda que servil, é um exercício que leva ao saber: é útil, inclusive, a "lição dos autores", ${ }^{44}$ espécie de exercício auxiliar da imitação, "porque com o estudo, \& auxílio della, observamos, \& alcançamos o que disseraõ, \& fizeraõ outros; \& dahi tomamos a copia das palavras, a variedade das figuras, o modo de dispor as obras, \& outros accidentes, de que a imitação servil se vale para se exercitar". 45

Leitão Ferreira divide ainda a imitação servil em três graus, de acordo com a sua maior ou menor dependência do modelo ou "protótipo": no primeiro grau, o

\footnotetext{
${ }^{42}$ Nova Arte de Conceitos. Primeira parte. Lisboa Occidental: Antonio Pedrozo Galram, 1718, p.151.

${ }^{43}$ Idem, p.152.

${ }^{44}$ Conforme as definições que Bluteau apresenta no seu Vocabulário Português e Latino, "lição" pode ser tanto "a acção de ler qualquer cousa escrita, ou impressa" quanto "o que o mestre dá ao discipulo cada dia para estudar" ou "o que o discipulo ha de tomar de cor" ou, ainda, "o que na aula o lente dicta aos seus estudantes, para que o tornem a ler, \& o repitão" (Bluteau, R. Vocabulario Portuguez, \& Latino, op.cit., volume 5, pp.117-118).

${ }^{45}$ Nova Arte de Conceitos, op.cit., pp.157-158.
} 
"exemplar" é apenas seguido, no segundo, é igualado e no terceiro, é excedido. Aquela imitação que se limita a seguir o modelo é de "ínfima condição", própria para principiantes ou "ânimos humildes", pois não dá um passo adiante do imitado, sendo duramente recriminada por Quintiliano e Policiano: aquele a chama de "inércia" e "frouxidão" e este diz que assim como não é possível correr com destreza quando só se busca colocar os pés sobre as pegadas alheias, da mesma forma não conseguirá escrever bem quem não se atreve a escapar dos vestígios da imitação. "Concluamos pois ser totalmente servil aquelle engenho, que só se contenta com ir apòs o imitado, sem dar hũ passo mais avante, com que o emparelhe, quando o não exceda". ${ }^{46}$ Segundo Leitão Ferreira, com esse grau de servidão se contentaram os imitadores de Góngora, tomando por exemplar aquilo que era natureza no poeta cordovês, e acabaram por escurecer a clareza do seu estilo. A boa imitação, diferentemente dessa servidão inerte, não torna a cópia idêntica ao copiado, mas sim muito semelhante; e é justamente na perfeita semelhança que consiste o "segredo" ou o "equívoco" por meio do qual se pode enganar o juízo, para que ele não seja capaz de distinguir a cópia do copiado. Porém, é essa também a maior dificuldade da semelhança e, consequentemente, da imitação, e só quem a vencer passará de imitador servil a nobre imitador. Para tanto, prescreve Leitão Ferreira:

Sejamos imitadores, naõ dos do primeyro grao dos servís, mas ou dos do segundo, ou dos do terceyro, que ou igualão, ou excedem os exẽplares. Proponhamos pois hum Author da melhor categoria, naquelle genero de obra que quizermos imitar; \& examinando, ou ponderando o caracter commum da obra, \& o particular do Author, que se imita, vejamos antes de entrar na imitaçaõ, \& competencia, em que primores, ou da arte, ou da natureza foy insigne, \& de que vicios, ou erros maculado; \& então evitando o mào, \& imitando o bom, trabalhemos, ou por igualallo, ou por excedello. ${ }^{47}$

Outra importante distinção que encontramos na Nova Arte de Conceitos é entre imitação e furto. O imitador é tido como "ladrão" quando toma ou furta as obras alheias

\footnotetext{
${ }^{46}$ Idem, p.160.

${ }^{47}$ Idem, p. 162.
} 
atribuindo-as, no todo ou em parte, a si mesmo. ${ }^{48}$ Nesse sentido, como bem observa João Adolfo Hansen, os poetas representados na Fênix Renascida e no Postilhão de Apolo (e podemos estender tal observação aos poetas seiscentistas portugueses em geral)

distinguiam nitidamente as noções de "piratear", "imitar" e "emular". Faziam tais distinções pensando no proveito decorrente de conhecê-las para não incorrerem no título desonroso de "ladrão" ou de "imitador servil". Pressupunham que o conhecimento e a aplicação das distinções eram fundamentais para obterem a fama gloriosa de "emuladores", como o cardeal Sforza Pallavicino prescreve em Arte dello Stile Insegnativo, de 1647. Sabiam que as noções de "roubar" ou "piratear" só eram aplicáveis aos casos em que um poeta dava como sendo própria uma composição feita por outro. ${ }^{49}$

No entanto, como ensina Leitão Ferreira, quando aplicadas ao exercício da imitação e da competição (ou "competência", como escreve o autor), as palavras "furtar" e "tomar" são tidas como metáforas: entre os escritores, há "roubo, furto, \& latrocinio, quando a mesma cousa em individuo inventada por hum, he usada ao depois por outro", 50 enquanto se ela for um "distinto indivíduo" (e percebemos aqui um eco da definição de imitação, citada anteriormente, feita por de Tesauro), não se pode dizer que a coisa foi tomada ou furtada, mas imitada ou competida, e apenas metaforicamente é possível chamar isso de roubo.

Enfim, para não incorrer em furto não metafórico, o imitador deve ser como a abelha, retomando Leitão Ferreira essa conhecida comparação:

Assim das substancias de muytas, \& differentes flores, que recolhe, altera, \& actua em seu breve, \& delicado ventriculo, tece a abelha o engenhoso favo, composto de mel, \& cera, fabricando huma substancia nova, diversa, \& individua na materia, na fórma, \& nas qualidades. Proporcionadamente pois hum grande engenho da Italia constituhio a

\footnotetext{
48 "Tomar, ou furtar das alheas obras, se diz propria, \& rigorosamente, quando alguem attribue a si, \& divulga por cousa sua em tudo, ou em parte, os escritos de outrẽ; por quanto o domino, \& posse de taes escritos, naõ contèm para o escritor outro proveyto, mais que a gloria que delles lhe redunda, em se saber, que elle foy o que os fez." (Idem, p.169).

${ }^{49}$ Hansen, J. A. "Fênix renascida \& Postilhão de Apolo: Uma introdução", op.cit., pp.49-50.

${ }^{50}$ Idem, p.171.
} 
abelha, symbolo do sagaz imitador, que com curiosidade solicita, vagando pela primavera dos livros, pelos jardins da eloquencia, \& pelos prados da poesia, \& prosa, vay colhendo as engenhosas metaforas, as venustas descripções, os nobres pensamentos, \& outras flores muytas, $\&$ digerindo-as, alterando-as, \& actuando-as na capacidade de sua fantasia, com o calor efficaz de seu engenho, converte por arte mais que espagirica, as palavras, os tropos, \& conceytos, que recolhe, em hũa nova, individua, \& inopinada substancia: Esta ou quimica, ou segredo, he huma arte de occultar a arte, ou furto metaforico da imitaçaõ, aprendida porèm da mesma abelha; a qual na textura do seu favo, \& no artificio do seu nectar, obra com hum taõ recatado, \& escondido modo, que veyo a ser adagio entre os homẽs o seu segredo. ${ }^{51}$

Também como a abelha, o imitador deve saber selecionar as flores mais fragrantes nos prados da poesia e da prosa, ou seja, deve buscar os melhores modelos do gênero em que pretende compor, para com eles aprender e competir:

Assim como a abelha não tece o doce favo do succo de quaesquer flores, mas procura o pasto das mais fragrantes; da mesma sorte o bom imitador, não se deve servir, para a sua imitaçaõ, quaesquer figuras, frazes, \& conceytos, mas lendo, \& observando os escritos de melhor nota, no genero de obra que fizer, imitará o mais singular, sutil, \& engenhoso delles, reduzindo a taes regras a sua imitaçaõ, que não pareça, que tresladou, ou traduzio, senaõ que competindo com o imitado, o igualou, ou o excedeo. ${ }^{52}$

Portanto, podemos afirmar que "os autores seiscentistas concebem a imitação a partir da autoridade (auctoritas) dos melhores antigos, oradores e poetas, sendo autoridade definida como a excelência de um gênero". 53 Atendendo à verossimilhança e ao decoro, os poetas do século XVII imitam seus modelos buscando superá-los com "agudezas mais agudas que as da obra imitada". 54

\footnotetext{
${ }^{51}$ Idem, pp.178-179.

${ }^{52}$ Idem, p.179. Vale observar que esse trecho tem como fonte citada Sêneca, que é um dos diversos autores a desenvolver a descrição da abelha como "símbolo do imitador" (conforme Leitão Ferreira).

${ }_{53}$ Carvalho, M. S. F. de. Poesia de Agudeza em Portugal, op.cit., p.102.

${ }^{54}$ Hansen, J. A. "Retórica da Agudeza". In: Letras Clássicas, n.4, 2000, p.326.
} 
A partir dessa noção geral de imitação, é possível discutir as especificidades da imitação lírica. Como vimos, na Poética aristotélica menciona-se a poesia ditirâmbica, mas, diferentemente da epopeia e da tragédia, pouco se esclarece a seu respeito. Assim, os tratados poéticos quinhentistas e seiscentistas, quando discorrem sobre a lírica, têm dificuldades para defini-la como imitação conforme a preceptiva poética antiga, em particular aristotélica. Talvez buscando consolidar e autorizar o gênero lírico, alguns autores, como Pinciano, sugerem que a poesia lírica seria sucessora da ditirâmbica antiga: "porque el nombre de dithiramba o zarabanda no suene más en nuestras orejas y con la cosa fea y indigna se destierre el nombre indigno; y sean, de hoy más, cuatro las primeras y principales especies de la poética: épica, trágica, cómica y lírica" ${ }^{55}$ Porém, é preciso ressaltar, como o faz Maria do Socorro Fernandes de Carvalho, que na própria Philosophía Antigua Poética de Pinciano são referidas algumas diferenças entre os poemas líricos e os ditirambos, em especial o fato de que "a ditirâmbica antiga era gênero poético que implicava a conjunção do canto, música e dança, com o mesmo modo de enunciação em que o poeta falava sempre, o que não ocorre nos poemas líricos modernos". 56

Essa associação da poesia lírica à música, no entanto, é quase sempre reforçada quando se comenta a origem dos "versos líricos", destacando-se o fato de terem sido cantados à lira, como se verifica, por exemplo, na seguinte definição do Vocabulário Português e Latino de Raphael Bluteau:

Lyrico. Versos Lyricos. Assim chamados, porque se cantavão à lyra. Diz-se das Odes Latinas, \& vulgares, \& dos versos, chamados Lyras. Na estimação dos Gregos a Poesia Lyrica he a mais antiga de todas, \& para louvar a Deos, \& inspirar virtudes a melhor. (...)

Poeta lyrico. Vates lyricus. Horat. O Poeta Lyrico, por antonomasia he Horacio. $^{57}$

Para compreendermos melhor as particularidades atribuídas à imitação lírica em fins dos anos Quinhentos e começo dos Seiscentos, vale recorrer a um dos raríssimos tratados que têm o gênero lírico como matéria principal, buscando caracterizá-lo de acordo com os preceitos retóricos e poéticos, antigos e modernos.

\footnotetext{
${ }^{55}$ Pinciano, A. L. Philosophía Antigua Poética, op.cit., p.425.

${ }^{56}$ Carvalho, M. S. F. de. Poesia de Agudeza em Portugal, op.cit., p.176.

${ }^{57}$ Bluteau, R. Vocabulario Portuguez, \& Latino, op.cit., volume 5, verb. "lyrico", pp.222-223.
} 
Referimo-nos ao Trattato della poesia lirica (1594), ${ }^{58}$ de Pomponio Torelli (uomo di lettere e conde de Montechiarugolo, na província de Parma), que é um caso exemplar e, ao mesmo tempo, incomum de uma obra voltada, exclusivamente, à discussão dos elementos retórico-poéticos da lírica, procurando, inclusive, definir essa poesia. ${ }^{59} \mathrm{~A}$ dificuldade e raridade desse trabalho são ressaltadas pelo próprio autor, na "Lezion Prima" de seu Trattato, na qual menciona, como também já o fizemos, o fato de Aristóteles ter discutido, longamente, a epopeia e a tragédia e não ter abordado o "artifício lírico". Torelli, além disso, confirma que, como destacamos, entre seus contemporâneos, quase ninguém discorre sobre a poesia lírica, algo que lhe parece um contrassenso, pois tanto mais a lírica precisava de comentadores quanto menos Aristóteles dela tinha tratado: "Et i moderni nostri, che sopra li tragici et epici componimenti e quanto circa di loro scrisse Aristotele fanno forse più romore di quello che bisogneria, di questa [poesia lirica], che bisogno avria di aiuto, quasi niente parlano". 60

Para suprimir essa necessidade, Torelli define, então, a poesia lírica: "immitazione di costumi et affetti diversi, fatta con diversa sorte di versi, congionti in un tempo, con l'armonia dei versi e ritmo dei piedi, per purgar gli animi dagli istessi affetti”. ${ }^{61}$ A partir dessa definição, que ressoa evidentemente a Poética de Aristóteles, são destacadas algumas questões que podem gerar conflitos com a doutrina poética antiga, em especial a aristotélica. Desse modo, o principal objeto (oggetto) do lírico é a imitação dos afetos (affetti), e se ele imita ações, somente o faz para exprimir afetos, da mesma forma, mas no sentido inverso, que o cômico, o trágico e o épico, conforme Aristóteles, imitam os costumes visando às ações. "Ma questa opinione, com'è nova, così portarà seco molte difficoltà". ${ }^{62}$ A primeira dificuldade ocasionada por essa “opinião nova” é que o poeta lírico imita falando sempre ele próprio e, por isso, segundo a concepção aristotélica de que "l'immitare sia parlare in persona d'altro", 63

\footnotetext{
${ }^{58}$ Utilizamos a seguinte edição: Torelli, P. Trattato della poesia lirica. Roma: Biblioteca Italiana, 2003. Disponível em: http://www.bibliotecaitaliana.it./indice/visualizza_scheda/bibit000505. No entanto, há, pelo menos, duas edições impressas desse texto de Torelli: Trattati di poetica e di retorica del Cinquecento. A cura di B. Weinberg. V.4. Bari: Laterza, 1974, pp.237-317; Poesie con il Trattato della poesia lirica. Introduzione di R. Rinaldi, testi, commenti critici e apparati a cura di N. Catelli, A. Torre, A. Bianchi e G. Genovese. Parma: Guanda, 2008.

${ }^{59}$ Agradecemos à Profa. Dra. Maria do Socorro Fernandes de Carvalho a indicação de leitura do Trattato della poesia lirica de Torelli, fundamental para o desenvolvimento de nosso trabalho.

${ }^{60}$ Trattato della poesia lirica, op.cit., p.1.

${ }^{61}$ Idem, p.17.

${ }^{62}$ Idem, p. 18 .

${ }^{63}$ Idem, p. 18 .
} 
não seria o lírico imitador. A segunda refere-se ao fato de que se Aristóteles afirma que quem imita, imita pessoas que fazem alguma coisa, sendo, portanto, a matéria (soggeto) das imitações as ações humanas, essa asserção aristotélica não se coaduna com a definição de lírica apresentada por Torelli, porque ou o poeta lírico não imitaria, ou imitando não imitaria afetos, mas ações; concluindo-se que os líricos, pouco imitando ações, imitadores não seriam. Finalmente, a terceira dificuldade diz respeito à parte da lírica que contém os louvores aos deuses e aos heróis: não sendo os primeiros desses louvores afetos, nem os segundos lenitivos da virtude heróica, segue-se, logicamente, que a definição proposta não convém a essa parte da lírica e, dessa maneira, não abraçaria todo o definido.

Para responder a essas dificuldades, Torelli ressalta, de início, que se a lírica não fosse imitação, não seria poesia, pois declarou Aristóteles na Poética que todas as espécies de poesia são imitações. Especificamente sobre a primeira dificuldade, a discussão apresentada se mostra um pouco confusa e não resolve o problema de maneira clara. Assim, Torelli não concorda com a opinião de Piccolomini que, ao comentar a divisão aristotélica dos três modos que o poeta emprega para falar - "o vero quando si veste della persona di chiunque si sia, immitando con parole le parole di quella,(...) o vero quando egli parla come il poeta, e questa è la seconda, immitando i fatti altrui con le sue proprie parole(...). La terza è quando si spoglia di poeta e parla come Vergilio, o invocando o lodando o riprendendo o dando giudicio nelle cose narrate",64 -, almeja excluir o terceiro modo de imitação, usando como argumento a autoridade de Aristóteles contra o próprio Aristóteles:

Dice Aristotele che quando il poeta non si veste l'altrui persona, cioè non introduce altri a parlare, non immita; e nondimeno dice il Piccolomini che il poeta immita in propria persona battaglie, fortune, assedii, azioni di magnanimo, di forte, di timido, di collerico. Immitando dunque allora il poeta più quando immita i fatti che quando immita le parole, bisogna interpretar Aristotele che intenda non che non immiti il poeta quando non si veste l'altrui persona, ma quando spogliandosi (come fa spesso Lucano) della persona del poeta si mostra interressato. ${ }^{65}$

\footnotetext{
${ }^{64}$ Idem, p. 19 .

${ }^{65}$ Idem, p. 19 .
} 
Ainda com relação à primeira dificuldade, Torelli se declara também em desacordo com a opinião de Minturno, para quem o imitar sem se vestir em outra pessoa é imitação imprópria, sendo os poetas que assim compõem imitadores impróprios. Mas se essa posição de Minturno fosse verdadeira, eles seriam antes impropriamente poetas, visto que só são poetas enquanto imitadores.

Em seguida, são retomados os três modos de imitação expostos na Poética aristotélica, ${ }^{66}$ para destacar, com base nos elogios de Aristóteles a Homero, que se o poeta narra e conserva sua pessoa, trata-se de uma imitação própria, não sendo, porém, uma imitação melhor ou pior, pois todas (épica, trágica, cômica, lírica) são imitações feitas com diversos modos. Portanto, os "valentes líricos" (valenti lirici), que se contentam em falar sempre eles próprios, poderão servir de exemplo, mesmo sem se vestirem em outra pessoa, já que não há regra em contrário na doutrina aristotélica.

Quanto à segunda dificuldade que suscita a definição da lírica proposta por Torelli, este, recorrendo a Piccolomini, afirma que o verbo "fazer" tem ampla significação, incluindo-se nele não apenas as verdadeiras ações, mas também o "falar", o "ver", o "sentir", o "dormir" e "velar" e, até mesmo, o verbo "estar", ao qual mais se opõe a ação. Além disso, "inquanto questo verbo [fare] include affetti e costumi, si conoscono gli uomini o beni o rei, ch'era l'intento d'Aristotele in quella particella che è per noi tutta." ${ }^{, 67}$ Dessa forma, não se nega que para se conhecer o interior é preciso "procedere a qualche esteriore", mas o afeto e o costume, como já ficou bem assentado, são a finalidade na poesia lírica, ainda que se tratem de operações.

Enfim, à terceira dificuldade, Torelli responde sucintamente: "Alla terza difficoltà dicemo che a' dèi con le persone si dànno gli affetti di misericordia e d'ira e d'amore, o per protegerci o per giovarci o per punirci, e questo giova a sedare e guarir le perturbazion nostre, ch'è l'intento della lirica.",68

Da quarta lição em diante, o que se passa a discutir no Trattato della poesia lirica é a imitação, sendo, portanto, conveniente fazer uma leitura mais cuidadosa dessas lições, pois o debate da imitação em geral permite ao autor destacar as peculiaridades da lírica, o que também estamos buscando neste nosso trabalho. Se a

\footnotetext{
${ }^{66}$ Torelli assim explica esses três modos de imitação: "Perciò che Aristotele distinse chiaramente l'immitazione nella XVa particella secondo il Maggio o nell'ottava secondo altri, ove dice che l'immitazione si fa o per via di narrazione, e questa divide in due parti, o ponendo alle volte il poeta se stesso in persona d'altri, come fa Omero, o conservando sempre la persona non mutata mai; nell'altro modo poi introducendo persone a negoziare." (Idem, p.20).

${ }^{67}$ Idem, p. 20.

${ }^{68}$ Idem, p.20.
} 
poesia lírica, como propõe o preceptista italiano em sua definição já mencionada, é uma “imitação de costumes e afetos diversos", é necessário, a princípio, entender em que consiste esse "imitar". Assim, em Aristóteles consta-se que todas as partes da poesia imitam e que, por isso, toda a poesia é imitação. Com base nessa constatação, Torelli apresenta a sua própria definição do que seja imitar: "Presupponiamo dunque che altro non sia immitare che un esprimere con rappresentare, un por inanzi ai sensi e per mezzo dei sensi all'animo le cose per l'imagini loro."69 E a finalidade de quem imita é representar mais vivamente, sendo sua matéria as imagens. "Quindi pare che tutte le cose sensibili immitar si possino, e che ogni cosa che imagine alcuna produchi, caschi sotto l'immitazione." ${ }^{, 70}$ Desse modo, tudo que é, é imitável, se compreendemos o ser como aquilo que está sob o governo dos sentidos. Consequentemente, imitam-se palavras e coisas, mas sendo as palavras simulacros e imagens dos nossos conceitos, elas são imitadas não como imagens, e sim como coisas reais que estão sob nossa audição e que são, de um modo ou de outro, compostas. Para Torelli, portanto, aqueles que imitam as palavras são "feitores de alguma coisa" (facitori d'alcuna cosa), e não imitadores (immitatori). Além disso, a imitação nasce dos diversos estilos (stili), sendo controverso o modo pelo qual ela deveria ser feita: universal, como sugere Giovan Francesco Pico, ou particular, conforme Pietro Bembo, que define essa imitação como um transferir a semelhança de estilo alheio para escritos próprios e usar o mesmo "temperamento no escrever" (temperamento nello scrivere) que o outro usou. Cícero também apresenta uma definição dessa imitação feita pelo modo particular: seria ela uma diligência que nós usamos ao falar (dire), pela qual nos fazemos semelhantes aos outros. Embasando-se nas considerações de Bembo e Cícero, "doi dottissimi uomini”, Torelli, então, afirma “ch'altro non è immitare che un'essatta diligenza per la quale esprimiamo l'altrui proprietà o con l'azioni o col dire o col nostro scrivere", sendo tal imitação particular do estilo uma imitação das palavras (di parole), que difere daquela dos conceitos (dei concetti), "la quale se sia rubamento o immitazione, e se il poeta si fabrica la materia com'altri ha tenuto, diremo al suo loco". 71

Torelli se volta, em seguida, para a concepção platônica de imitação. No Sofista, Platão concede que todas as coisas sensíveis possam ser imitadas, e o espelho seria o imitador por excelência. Essa imitação é definida, nesse mesmo diálogo

\footnotetext{
${ }^{69}$ Idem, pp.22-23.

${ }^{70}$ Idem, p. 23.

${ }^{71}$ Idem, p. 23.
} 
platônico, como feitura (fattura) de imagens e simulacros. Assim, considera Platão a "facoltà effettrice" (isto é, a capacidade de fazer algo) uma força que se divide em humana e divina e é causa de certas serem o que, primeiramente, não eram, atribuindo à divina os efeitos de todas as coisas naturais, tanto animadas quanto inanimadas, e à humana os efeitos daquelas que por obra humana se veem feitas. Os simulacros dos primeiros e dos segundos desses efeitos, realizados ou por arte dos "demônios" (demoni) ou por outras artes imitativas como a pintura e a escultura, é que Platão chama de imitação.

Além disso, são referidos os três modos pelos quais as coisas podem ser consideradas ou suas três diversas maneiras de "ser", de acordo com a doutrina platônica. O primeiro ser é o divino, que tem todas as coisas na mente divina, na qual as Ideias de quaisquer coisas reluzem. O segundo é o ser natural, que tem cada coisa com a sua particular porção da matéria. O terceiro é aquele que se explica na imitação, sombra e imagem do segundo da mesma forma que o segundo é símile do primeiro. Se o primeiro tem um único e verdadeiro efeito, que da razão única de todas as coisas deriva, o segundo artífice ou feitor (facitore) é fabricador (fabricator) do seu efeito de tal maneira que dele não provém o verdadeiro efeito, mas um determinado efeito. Já o terceiro, não é mais possível designá-lo como feitor ou artífice, e sim como imitador. Por isso, Platão chama o imitador de terceiro "facitor per natura", ou seja, imitando naturalmente com o instinto, o imitador é "o terceiro da verdade" (il terzo dalla verità); e ele faz imagens e sombras, mas imagens da virtude, e não a verdadeira virtude.

Depois de apresentar essa concepção platônica da imitação, Torelli afirma que "Platone, concedendo qualche immitazione, non tutte le danna, ma quelle sole che sono inutili, accettando in esse ciò che utile pò apportare alla sua republica, bene quelle immitazioni biasma che solo diletto procacciano". 72 Para ser um bom imitador, é necessário saber três coisas: primeiro, conhecer aquilo que se deseja imitar; segundo, se é bom e útil imitá-lo; terceiro, é preciso imitá-lo bem, conjugando, se se trata de um poeta, as palavras com os conceitos, os conceitos com os números, de tal forma que uns com outros convenham otimamente, fazendo, ao reunir tudo, uma perfeita imitação. Portanto, Platão se indispôs contra os "imitadores tristes" (immitatori tristi), não contra os imitadores em geral, porque, de outro modo, não os admitiria nem diria que a

\footnotetext{
${ }^{72}$ Idem, p.26.
} 
imitação poética é um certo encanto que incita os ânimos dos jovens à virtude, como o fez no segundo diálogo das Leis.

Ainda discutindo a noção geral de imitação, Torelli refere, na quinta lição de seu Trattato, a divisão aristotélica da mimesis: segundo a matéria, quando se imitam coisas diversas; de acordo com os instrumentos, quando com diversos instrumentos se faz a imitação; e conforme os modos, diferindo-se a maneira e o modo de imitar. Para o preceptista italiano, essa divisão de Aristóteles englobaria todas aquelas propostas por Platão. Assim, Torelli, mencionando a opinião de Castelvetro de que a poesia seria imitação da história, apresenta uma primeira divisão platônica da imitação: histórica e verdadeira - aquela segue a verdade, esta a opinião. Além disso, Platão divide a imitação, no terceiro diálogo da República, em narração simples (quando o poeta fala sempre ele mesmo, como nos ditirambos), em imitação propriamente dita (constituída tanto por atos quanto por pessoas que falam em cena, como na tragédia e na comédia) e, finalmente, em composta (imitação característica dos poetas épicos, que tanto narram na própria pessoa, como Virgílio em muitos livros da Eneida, quanto fazem outros falarem, como faz o mesmo Virgílio com Eneias). Evidentemente, essa segunda divisão platônica se reduz àquela aristotélica dos modos pelos quais se pode imitar. Uma terceira divisão de Platão, que pode ser comparada à de Aristóteles quanto à matéria imitada, é aquela entre coisas meramente naturais - quando se imita, por exemplo, um touro mugindo, um cavalo relinchando, o frêmito do mar, o murmurar dos rios, o espanto dos terremotos - e coisas artificiais (artificiali) ou que procedem do nosso ânimo (animo) - como uma menina que chora, a esposa que ri com o marido, alguém que se acende de ira, alguém que por amor languesce, alguém que sofre as dores do parto, alguém que se reputa miserável ou feliz, os escravos, as escravas, aqueles que estão condenados ao remo, as obras das artes. Por fim, Torelli menciona aquela que seria a principal divisão platônica: imitar o universal ou o singular. Podem-se representar vários homens ou várias mulheres numa única imitação ou apenas um homem ou uma mulher, sendo sempre a primeira imitação, universal, mais poética (più poetica) que a segunda, singular.

Quanto à finalidade da imitação, na sexta lição do Trattato della poesia lirica, afirma-se, com base em Aristóteles, que o aprender (imparare) é aquilo a que visa a imitação. Além disso, conforme Platão, o imitar pressupõe o saber. Surge, assim, a dúvida de como pode a imitação ter como finalidade o saber se o saber é seu pressuposto. Responde Torelli a essa questão recorrendo, mais uma vez, à autoridade 
aristotélica para dizer, a princípio, que o entender (intendere) é o imitar. Todavia, desenvolvendo um pouco mais essa afirmação, o preceptista italiano explica que o entender não se dá sem a imitação, mas isso não significa que o entender seja imitação. Embora imitando se possa aprender, não se deve concluir que o imitar seja o entender, mas sim que é essa a via que conduz ao entender e ao aprender. Se, como se verifica na Ética aristotélica, o saber se dá por semelhança (similitudine) e parentesco (parentella), "l'immitazion dunque e cognizion presuppone et alla cognizione è ordinata, perché immitando ogni proprietà accidentale impariamo, e quindi potiamo più agevolmente immitare". ${ }^{73}$ Além de pressupor a cognição e de estar à cognição sujeita, a imitação é deleitável, como o mostra Aristóteles na Poética, mesmo que as coisas imitadas nos entristeçam ou aborreçam, pois, como complementa Plutarco, o deleite não provém das coisas imitadas, mas do fato de serem bem imitadas.

Após essas discussões sobre a concepção de imitação em geral, Torelli declara ter já tratado suficientemente do tema e anuncia que passará a expor as diferenças ou especificidades da poesia lírica, que a distinguem das outras "espécies de poesia" (spezie di poesia). Uma primeira particularidade da lírica é ser ela uma imitação de afetos e costumes, e não de ações, como a cômica, a trágica e a épica. Essa diferença refere-se ao assunto ou à matéria da poesia, sendo oportuno, portanto, retomar-se a opinião de Castelvetro, para quem a poesia seria imitação de história, isto é, seria a lírica uma “istorica immitazion”. Uma das consequências dessa afirmação de Castelvetro é que, tendo dito Aristóteles que quem imita, imita pessoas (sejam elas piores, melhores ou semelhantes) que fazem alguma coisa, a imitação seria sempre de ações. Torelli rebate esse ponto de vista, recorrendo à autoridade de Piccolomini:

Ma perché e gli affetti e i costumi si ponno anco immitare, interpretaremo noi quel fare universalissimamente, in quanto lo starsi, l'arrossirsi, il tacersi include. E questo con l'autorità del Piccolomini, come mi ricordo d'avervi altre volte interpretato, perché dall'illazione si mostra la mente d'Aristotele ch'era da quell'azione cavar la differenza del soggetto, ch'era dei megliori, dei peggiori, dei simili. Questo, perché dal verbo fare inquanto e costumi et affetti et azioni abbraccia si pò dedure, bisogna anco in questa universal significazion intenderlo. ${ }^{74}$

\footnotetext{
${ }^{73}$ Idem, p. 38.

${ }^{74}$ Idem, pp.40-41.
} 
Além disso, Torelli também lança mão da autoridade aristotélica para ressaltar que a história representa em particular e a poesia em universal; aquela como as coisas ocorreram e esta como poderiam, mais verossimilmente e de maneira melhor, ocorrer. Por isso, são diferentes suas matérias; especificamente, a lírica imita afetos e costumes, que não são levados em consideração no modo narrativo histórico, senão por acidente e como acessórios, se servirem às ações ou se forem as ações por eles alteradas.

Rebatida a opinião de Castelvetro, comenta-se, em seguida, a de Robortello, que considerou o falso como matéria da poesia: "diremo che 'l vero e 'l falso siano per accidente e che il conveniente e verisimile al poeta propriamente apartenghino. Bene è vero che più tosto e più spesso occorrerà al poeta il falso che 'l vero, et in questo salvaremo con la verità il nostro maestro" ${ }^{75}$

Finalmente, fechando a sexta lição de seu tratado, Torelli apresenta uma dificuldade que surge quando se pensa na matéria principal dos poetas líricos: os afetos. Sendo estes próprios daqueles e bem compondo um lírico quando incitado pelo seu próprio afeto (como Dante preceituou), segue-se que a poesia lírica seria mais história que poesia, pois, dessa forma, seria uma história dos afetos próprios, os quais, narrados, não imitariam os alheios. Portanto, os líricos seriam mais narradores do que imitadores. Porém, o preceptista di fine Cinquecento resolve essa questão, baseando-se em Aristóteles para declarar que os líricos, sendo poetas, necessariamente sempre imitarão, pois dizer as coisas "em universal” (in universale) é dizê-las não como aconteceram verdadeiramente, mas como deveriam acontecer, isto é, aquilo que seria possível segundo o verossímil ou necessário. Assim, os líricos tratam de seus próprios afetos e de costumes alheios:

A questa opposizione si risponde che il lirico, essendo poeta, necessariamente immitarà sempre; e se conterà i suoi amori, le lodi della donna sua, serverà il precetto di Aristotele nella particella 52 della Poetica, ch'è di dir le cose non secondo che sono veramente accadute, ma secondo che accascar dovrebbono, e dir insomma quello che è in sé possibile secondo il verisimile o necessario. E perciò distingue ivi il filosofo tra il poeta e l'istorico, che l'uno dice le cose secondo che avenute sono, e l'altro secondo che dovrebbono avenire. Perciò la poesia più di filosofo è degna e maggior studio e considerazion ricerca, conciò

\footnotetext{
${ }^{75}$ Idem, p. 42 .
} 
sia che dica le cose più nel loro universale. Et il dir in universale è il dir le cose tali quali alle tali e tali persone devono accascare di dirsi o farsi, secondo il necessario o verisimile. Così dunque tratterà il lirico gli affetti suoi et i costumi altrui. E se averrà che occorra per ventura che '1 soggetto sia tale quale esser dovria, cioè in sommo grado di perfezione, quale di Laura e l'amor del Petrarca stimar si deve (ancor che chi non lo stimasse non saria articolo di fede), questo è accidente alla poesia, che non a quel che aviene ha l'occhio ma a quel che doveva avenire. ${ }^{76}$

Na sétima e última lição do Trattato della poesia lirica, são analisados os elementos que restam da definição de poesia lírica proposta, quais sejam: com que instrumentos, com que modo e para qual fỉm se faz essa imitação. É válido, nesse sentido, recordarmos tal definição, como também o faz Torelli: "Dissi ch'era immitazione d'affetti e costumi, fatta con diversa sorte di versi, congionti nello stesso tempo con ritmo et armonia, per purgar l'animo da quegli affetti ch'ella proposti s'avea d'immitare". ${ }^{77}$ Desse modo, nota-se que o instrumento da imitação lírica é a diversidade de versos, o ritmo e a harmonia. Diferenciam-se os poetas líricos dos épicos, porque estes últimos usam apenas um tipo de versos e não usam o número ou ritmo nem a harmonia; os cômicos e trágicos também não apresentam a diversidade de versos dos líricos, pois se contentam somente com o iambo.

Quanto ao modo, que na definição se refere ao "nello stesso tempo" e está diretamente relacionado aos instrumentos, o poeta lírico serve-se tanto do iambo como de outros tipos de versos, conjugando-os sempre com o canto e com a dança (ballo). "Lo stromento dunque del lirico sarà la diversità dei versi, il ballo, e 'l canto". ${ }^{78}$ E essa diversidade de versos, que, entre todos os poetas, é usada em particular pelo lírico, procede da diversidade dos afetos. Isso porque, pouco estáveis são os nossos afetos e a própria natureza e sua essência consistem em mutação. De diversos versos se serve o poeta lírico devido aos diferentes afetos que, a todo momento, vemos nascer em nós. Por isso, a poesia lírica é composta de diversas sortes de imitações, ou melhor, todas estas variadas imitações se distinguem melhor naquela poesia.

Torelli retoma, em seguida, a divisão aristotélica das matérias e dos assuntos da imitação, que variam conforme três sortes de pessoas: imitam-se ou as melhores, ou as

\footnotetext{
${ }^{76}$ Idem, p.43.

${ }^{77}$ Idem, p.43.

${ }^{78}$ Idem, p.44.
} 
piores ou, ainda, as semelhantes (simili). Na lírica, é que se celebram melhor os melhores, como os deuses e os heróis, é que se detestam mais os piores e que se veem mais bem retratados, nos semelhantes, os afetos humanos, sejam amorosos ou de dor. Assim, "si che per la diversità degli affetti, per l'incerta qualità loro, ebbe bisogno il lirico d'un sì vario soggetto quale è la diversità dei versi. Sono i versi parte della poesia, e parte propria se la consideriamo perfetta, onde la forma sarà l'immitazione e non la materia come par che volesse tenere il Castelvetro; e la materia sarà il verso". ${ }^{79}$ Posto que a matéria da poesia é o verso e a forma é a imitação, e se, como afirmou Aristóteles na Poética, o poeta é formador (formator) mais de fábulas do que de versos, conclui-se que a imitação pode ser feita tanto em verso quanto em prosa; todavia, para que seja um poeta perfeito, requere-se, necessariamente, o verso. Portanto, o verso é parte da poesia e, com relação à imitação, é instrumento.

Outros instrumentos da imitação lírica, como se depreende da definição de Torelli, são o ritmo e a harmonia. Se esses instrumentos se encontram em todo verso, parece desnecessário acrescentar aos versos ritmo e harmonia, pois Aristóteles, ao discutir as causas naturais da poesia, determinou que eram elas a imitação, o número e a harmonia. Dessa maneira, no verso há sempre ritmo e harmonia, não sendo, por isso, a proporção do rápido (veloce) com o lento (tardo), que há em todos os versos, outra coisa senão o número, e nada mais é o ritmo do que um hábito (abitudine) que têm as sílabas longas ou breves, ou por natureza ou por acentuação (acento), como nas línguas românicas, e a composição desses hábitos ou proporções, isto é, de ritmos menores, nada mais é do que o verso; finalmente, posto que da celeridade advém o verso agudo e da lentidão o grave, nasce, por conseguinte, a harmonia no verso não de vozes refratárias (voci refratte), mas da união de ritmo, pelo alçar e abaixar a voz. Assim, resultando a harmonia do número, para que seja o verso com número perfeito, convém que resulte de uma harmonia também perfeita. Torelli encerra, então, esse tema, reforçando a fundamental importância da harmonia e do número e redefinindo essas partes essenciais da poesia lírica:

Ma la melodia e 'l numero, in quanto è differente dal verso, diciamo immitare et esser parte essenziale della lirica. Dico numero di mozioni di piedi e di tutto il corpo, et armonia di voci refratte e d'instromenti, acciò che la lirica conformando l'immitazion degli affetti, fatta col

\footnotetext{
${ }^{79}$ Idem, p.45.
} 
parlare, con la correspondente immitazione dei movimenti del corpo, e con l'immitazione dell'armonia, con certa regola temperi e l'animo e '1 corpo nostro, mostrando con l'essempio dell'armonia e moto dei cieli la bellezza vera dell'uomo, che in una proporzione e leggiadria e d'animo e di corpo consiste. Onde antichissima è questa poesia, perciò che non è tempo che alla cognizione di Dio non fossero congionte le lodi che a quello meritamente si devono. Oltreché, gli affetti che al poetar spingono, più in questa, come dicemo, che in alcun'altra poesia si scorgono. ${ }^{80}$

Por fim, vale destacar algumas considerações relevantes sobre a lírica que são apresentadas ainda nesta última lição do Trattato della poesia lirica. Torelli ressalta, por exemplo, que os poetas líricos não apenas louvam ou elogiam, mas também vituperam, pois a eles pertencem tanto os hinos (imni) quanto os vitupérios. Além disso, o preceptista conclui que a imitação lírica se faz com o som (suono), com a dança (ballo) e com o verso, o que poderia gerar a seguinte dúvida: se seriam líricos os poemas modernos, uma vez que não são bailados, faltando, portanto, uma parte essencial da definição de lírica. A essa dúvida se responde com base na autoridade aristotélica: faltando o verso, poderia haver poesia, mas não perfeita, já que a perfeição, nesse caso, é o verso unido à imitação. E se são necessários ainda o som, o canto e, consequentemente, a dança, é somente para recitar-se a poesia, posto que nela estão presentes em potência e o poeta fez aquilo que era preciso, sendo, por isso, o poema perfeito, podendo-se recitá-lo, perfeitamente, acrescentando o som e o canto. Enfim, o poema é feito para ser lido, e não cantado ou dançado.

Torelli salienta também uma questão quanto ao modo da imitação lírica: como se verifica em vários poemas de poetas como Catulo, Horácio, Tibulo e Petrarca, não é possível afirmar que a lírica é apenas narrativa, falando sempre o próprio poeta, pois os poetas líricos fazem, não raramente, outros falarem. Sendo assim, conclui Torelli que o poeta lírico, com relação aos modos empregados para imitar, é livre, embora utilize, mais frequentemente, o narrativo: "Io perciò mi risolvo che nei modi sia il lirico libero, ancor che per lo più vi vegga il narrativo". ${ }^{81}$

Para fechar o Trattato della poesia lirica, faltaria, segundo seu autor, comentar a última parte da definição proposta de poesia lírica, que diz respeito à finalidade de

\footnotetext{
${ }^{80}$ Idem, p.47.

${ }^{81}$ Idem, p.49.
} 
purgar o ânimo dos mesmos afetos que se imitam. Sobre essa questão, no entanto, já teriam falado o bastante os comentadores da Poética, ao discutirem a definição da tragédia, e o próprio Torelli, quando mostrou que esse é o fim do poeta lírico e declarou que esse "purgar" se refere ao excesso e não a todo afeto, não havendo, por isso, muito mais a ser dito. Porém, são mencionados ainda versos de Petrarca ("Ma ben veggio hor sì come al popol tutto / Favola fui gran tempo"), Horácio ("Heu me per turbam, nam pudet tanti mali, / Fabula quanta fui") e de Tibulo ("Fabula nunc ille est"), para ressaltar-se algo que nos parece fundamental quando se pensa na poesia lírica seiscentista: cantam-se, nos poemas líricos, os amores para nos fazer fugir dos amores lascivos e nos conduzir ao verdadeiro e perfeito amor; e pintam-se os furiosos (adirati) para que neles, como num espelho, vejamos que esse afeto (a ira) nos tolhe aquela bela semelhança que temos com a razão e, assim, sejamos incitados a guardá-la. ${ }^{82}$

Esse exame detalhado da imitação lírica feito no Trattato della poesia lirica, de Pomponio Torelli - que, como já salientamos, é um dos raríssimos tratados, em fins do século XVI e começo do século XVII, voltados, exclusivamente, para uma discussão retórico-poética específica sobre o gênero lírico - nos permite afirmar que a lírica seiscentista imita afetos para, além de deleitar, também instruir sobre esses afetos imitados (entre eles, o amor). Nessa prática mimética, um poema lírico evoca outro que, por sua vez, remete a um terceiro que, possivelmente, se baseia em outras fontes, num exercício de múltiplas imitações, relacionadas a nomes de poetas que se constituem como autoridades da lírica. É o que podemos observar, por exemplo, num conhecido soneto atribuído a Gregório de Matos: ${ }^{83}$

\section{Discreta, e formosíssima Maria,}

Enquanto estamos vendo a qualquer hora

Em tuas faces a rosada Aurora,

Em teus olhos, e boca o Sol, e o dia:

\footnotetext{
82 "Onde non per altro cantarono gli amori che per farci fuggire gli amori lascivi e ridurci al vero e perfetto amore. Né per altro gli adirati ci depinsero se non perché in loro come in uno specchio vedessimo quanto questo affetto ci tollesse di quella bella sembianza che abbiamo della ragione, e però ce ne guardassimo." (Idem, p.50).

${ }_{83}$ Ao mencionarmos Gregório de Matos, não podemos nos esquecer do estudo de João Adolfo Hansen, $A$ sátira e o engenho: Gregório de Matos e a Bahia do século XVII (São Paulo: Ateliê Editorial; Campinas: Editora da Unicamp, 2004), que discute amplamente a poesia do século XVII e, em especial, a sátira seiscentista, além de nos fazer repensar a própria figura do poeta Gregório de Matos e a constituição de sua obra poética. Além disso, acerca desse tema, é fundamental também o trabalho de Marcello Moreira: Critica Textualis in Caelum Revocata? Uma Proposta de Edição e Estudo da Tradição de Gregório de Matos e Guerra. São Paulo: Edusp, 2011.
} 
Enquanto com gentil descortesia

$\mathrm{O}$ ar, que fresco Adônis te namora,

Te espalha a rica trança voadora,

Quando vem passear-te pela fria:

Goza, goza da flor da mocidade,

Que o tempo trota a toda ligeireza,

E imprime em toda a flor sua pisada.

Oh não aguardes, que a madura idade

Te converta em flor, essa beleza

Em terra, em cinza, em pó, em sombra, em nada. ${ }^{84}$

Ao ouvir ou ler esse poema, o ouvinte ou o leitor agudo da época deveria se lembrar, de imediato, dos sonetos "Mientras por competir con tu cabello" 85 e "Ilustre y hermosísima María", ${ }^{86}$ ambos de Góngora ${ }^{87}$ e muito imitados durante todo o século XVII. Os três poemas exploram a tópica antiga do carpe diem, cristalizada por poetas como Ausônio e Horácio. ${ }^{88}$ Em “Mientras por competir con tu cabello", a persona lírica dirige-se a uma dama, mostrando-lhe que enquanto seu cabelo for ouro polido, sua face branco lírio, seus lábios cravos e seu pescoço luzente cristal, deve gozar a beleza e a juventude; antes que a passagem do tempo transforme toda essa beleza, perfeita em cada parte do corpo mencionada, "en tierra, en humo, en polvo, en sombra, en nada". O outro soneto de Góngora, "Ilustre y hermosísima María”, é também um convite ao

\footnotetext{
${ }^{84}$ Citamos o soneto com base na seguinte edição do Códice James Amado: Gregório de Matos. Crônica do Viver Baiano Seiscentista: obra poética completa. $4^{\mathrm{a} e d}$. Rio de Janeiro: Record, 1999, p.507. Vale lembrar que João Adolfo Hansen também fez uma breve análise desse soneto em seu texto introdutório à coletânea Poesia seiscentista - Fênix renascida \& Postilhão de Apolo (op. cit., pp.54-55).

85 "Mientras por competir con tu cabello / oro bruñido al sol relumbra en vano; / mientras con menosprecio en medio el llano / mira tu blanca frente el lilio bello ; / mientras a cada labio, por cogello, / siguen más ojos que al clavel temprano, / y mientras triunfa con desdén lozano / del luciente cristal tu gentil cuello, / goza cuello, cabello, labio y frente, / antes que lo que fue en tu edad dorada / oro, lilio, clavel, cristal luciente, / no sólo en plata o víola troncada / se vuelva, mas tú y ello juntamente / en tierra, en humo, en polvo, en sombra, en nada." (Góngora, L. de. Sonetos Completos. Edición introducción y notas de Biruté Ciplijauskité. Madrid: Castalia, 1992, p.230).

86 "Ilustre y hermosísima María, / mientras se dejan ver a cualquier hora / en tus mejillas la rosada aurora, / Febo en tus ojos, y en tu frente el día, / y mientras con gentil descortesía / mueve el viento la hebra voladora / que la Arabia en sus venas atesora / y el rico Tajo en sus arenas cría; / antes que de la edad Febo eclipsado, / y el claro día vuelto en noche obscura, / huya la aurora del mortal nublado; / antes que lo que hoy es rubio tesoro / venza a la blanca nieve su blancura, / goza, goza el color, la luz, el oro." (Idem, p.231).

${ }^{87}$ A lírica seiscentista produzida em Portugal e na América Portuguesa tem como um de seus modelos mais próximos e importantes, ao lado de Camões, Góngora. Como já mencionado, o trabalho de José Ares Montes, por exemplo, defende a controversa tese de que seria Góngora o principal modelo da poesia portuguesa do século XVII (Góngora y la Poesía Portuguesa del Siglo XVII, op.cit.).

${ }^{88}$ Para uma discussão sobre a "genealogia do carpe diem" na poesia antiga (especialmente em Horácio) e sua presença na poesia portuguesa e brasileira, veja-se: Achcar, Francisco. Lírica e lugar-comum: alguns temas de Horácio e sua presença em português. São Paulo: Edusp, 1994, pp.59-126.
} 
gozo: enquanto Maria for jovem e bela, e suas bochechas forem rosadas como a aurora, seus olhos dourados como o sol e sua face luzente como o dia, "antes que de la edad Febo eclipsado, / y el claro día vuelto en noche obscura, / huya la aurora del mortal nublado; / antes que lo que hoy es rubio tesoro / venza a la blanca nieve su blancura", deve Maria gozar a cor, a luz, o ouro.

O primeiro verso desse último poema de Góngora que mencionamos - e, por conseguinte, daquele soneto atribuído a Gregório de Matos que o imita - trata-se de um verso de Garcilaso de la Vega (égloga III, v.2) muito reproduzido por poetas ibéricos dos séculos XVI e XVII. Em Portugal, Camões, por exemplo, parece ter retomado o verso garcilasiano para se referir à Dona Maria, esposa de Afonso XI de Castela: "Entrava a fermosíssima Maria” (Os Lusíadas, III, v.102). Já Francisco Manuel de Melo, em suas Obras Métricas, no verso final do soneto LXXII da Harpa de Melpomene, é mais explícito e reproduz exatamente o "ilustre y hermosísima María" de Garcilaso, talvez a partir de uma imitação do soneto de Góngora. ${ }^{89}$

As semelhanças entre aquele poema que se atribui a Gregório de Matos, "Discreta, e formosíssima Maria”, e os sonetos citados de Góngora são evidentes. As metáforas gongóricas, já mencionadas, que representam o corpo belo e jovem da dama, são modelos para a persona lírica de "Discreta e formosíssima Maria" que, ao emular, reinventa-as: as faces são aurora rosada, os olhos são o sol, a boca é o dia e o cabelo é "rica trança voadora". Além disso, a primeira estrofe do soneto atribuído a Gregório de Matos é praticamente uma tradução da estrofe inicial de "Ilustre y hermosísima Maria" de Góngora: "Ilustre y hermosísima María, / mientras se dejan ver a cualquier hora / en tus mejillas la rosada aurora, / Febo en tus ojos, y en tu frente el día...”. Nos três poemas, enfim, há o apelo ao gozo: "goza cuello, cabello, labio y frente”, "goza, goza el color, la luz, el oro", "goza, goza da flor da mocidade"; apelo esse que é intensificado pela contraposição da passagem do tempo (tempus fugit), que transforma a beleza e a mocidade "em terra, em cinza, em pó, em sombra, em nada".

Esse verso final do soneto "Discreta, e formosíssima Maria", que segue de perto o modelo gongórico de "Mientras por competir con tu cabello", recolhe, agudamente, os conceitos poéticos ${ }^{90}$ disseminados ao longo de todo o poema,

\footnotetext{
${ }^{89}$ José Ares Montes dá outros exemplos de poetas portugueses dos séculos XVI e XVII que reproduziram o referido verso de Garcilaso (Góngora y la Poesía Portuguesa del Siglo XVII, op.cit., pp.338-339).

${ }^{90}$ De acordo com João Adolfo Hansen, "o conceito figurado torna-se poético quando se toma a coisa significante (...) pela significada (...) de modo que a significante, suas paixões e propriedades, possam ser entendidas como propriedades e paixões da significada. O conceito poético é, no caso, o gênero comum
} 
amplificando a tópica do tempus fugit. Mas ao passo que no soneto de Góngora a passagem do tempo é representada pela transformação do "ouro", do "lírio", do "cravo" e do "cristal luzente" (metáforas da juventude e da beleza da dama) na "prata" e na "violeta truncada" da velhice; no poema atribuído a Gregório de Matos, o tempo é um cavalo que trota velozmente pisando todas as flores, inclusive as flores da mocidade e da beleza. A persona lírica mostra, assim, que logo o rosto da dama será como as flores pisadas e, além disso, já anuncia a morte, que converterá tudo em nada. Com a "novidade" de metáforas agudas como essa do cavalo-tempo, os poetas seiscentistas tentavam superar seus modelos, cabendo aos leitores cultos da época julgar se a emulação resultou numa imitação engenhosa ou meramente servil. ${ }^{91}$

Além disso, esse soneto atribuído à autoridade lírica "Gregório de Matos" nos sugere a discussão de uma questão mencionada anteriormente, porém ainda não desenvolvida devidamente: a imitação se orienta pela auctoritas que, por sua vez, determina a excelência de um gênero. Por isso, a compreensão do gênero lírico deve passar pelas autoridades que o compõem, mas, no caso da poesia seiscentista, essas autoridades não devem ser confundidas com “autorias”. Em meio à profusão de sonetos, romances, glosas, canções, madrigais, fábulas, epigramas e décimas (apenas para citar as espécies métricas mais correntes no século XVII), temos que lidar com uma constante incerteza de atribuição de autoria, de datação dos poemas e de variantes textuais. Isso porque, essa poesia, ou melhor, o que nos restou dessa poesia se encontra em manuscritos e impressos seiscentistas e setecentistas que não se pautam pelos mesmos critérios autorais e de originalidade nossos contemporâneos. Além disso, muitas vezes, a autoridade não decorre do nome de um poeta, e sim da própria composição, julgada excelente segundo os ditames do gênero em que está inserida. Daí a considerável quantidade de poemas que embora circulem anônimos nos anos Seiscentos, não perdem sua auctoritas. Na Fênix Renascida, por exemplo, foram publicados diversos textos anônimos, podendo ser mencionada uma composição lírica

que reúne duas espécies de conceitos aproximados por semelhança" ("Fênix renascida \& Postilhão de Apolo: Uma introdução", op.cit., p.55).

${ }^{91}$ Como explica Aníbal Pinto de Castro, embora esteja se referindo à poética quinhentista, "a imitação servil era radicalmente repudiada pelos seus próprios defensores. (...) A imitação não podia, pois, ser um decalque; antes pressupunha uma superação do modelo, tanto na invenção, como na disposição e na elocução poética, obtida através de uma verdadeira e completa assimilação de alguns dos elementos constitutivos do discurso." (Castro, A. P. de. "Os códigos poéticos em Portugal do Renascimento ao Barroco. Seus fundamentos, seus conteúdos, sua evolução”. In: Separata da Revista da Universidade de Coimbra, vol.31, 1984, p.519). 
que faz parte de uma série de "sonetos vários de um anônimo" do tomo IV dessa coletânea:

\section{Definiçaõ do amor.}

He hum nada amor, que póde tudo;

He hum naõ se entender o avizado;

He hum querer ser livre, e estar atado,

He hum julgar o parvo por sizudo.

He hum reparar os golpes sem escudo;

He hum cuidar que he, e estar trocado;

He hum viver alegre, e enfadado;

He naõ poder fallar, e naõ ser mudo.

He hum engano claro, e muy escuro;

He hum naõ enxergar, estar vendo;

He hum julgar por brando ao mais duro.

He hum naõ querer dizer, estar dizendo;

He hum no mór perigo estar seguro;

He por fim hum naõ sey que, $\tilde{q}$ naõ entendo. ${ }^{92}$

Num manuscrito depositado na Biblioteca Pública de Braga, intitulado Jardim Cultivado com varias flores parnasianas nacidas de diversos engenhos, acumulandoas a este volume a curiosidade, para entertenimento do gosto e no qual há várias composições atribuídas a Jerônimo Baía, encontra-se, também dito anônimo, esse mesmo soneto que transcrevemos, mas com algumas variações no texto. ${ }^{93}$ Não nos interessa, neste momento, discutir essas diferenças textuais, e sim apenas destacar que um poema não perde sua "autoridade" por não ter um "autor" ou por apresentar diversas lições textuais. A auctoritas desse soneto provém de sua inserção bem sucedida no gênero lírico, a começar pelo fato de ser uma imitação não servil de um importante

\footnotetext{
${ }^{92}$ A Fenix Renascida ou obras poeticas dos melhores engenhos portuguezes. Segunda vez impresso e acrescentado por Mathias Pereira da Sylva. Lisboa: Offic. dos Herd. de Antonio Pedrozo Galram, 1746, tomo IV, p.403.

93 "He hũ nada amor q̃ pode tudo / he hũ naõ se entender o auizado / he hũ querer ser liure, e estar atado / he hũ julgar o paruo por sezudo; / He hũ reparar golpes sem escudo / he hũ cuidar q̃ he aquelle, e estar trocado / he hũ viuer alegre e emfadado / he hũ naõ poder falar, e naõ ser mudo; / He hũ engano claro, e mui escuro / he hũ naõ enxergar, e estar vendo / he hũ jugar por brando, o q̃ he duro; / he hũ naõ querer dizer, e estar dizendo / he hũ no major perigo estar seguro, / e he hũ naõ sei q̃, nem o entendo." Jardim Cultivado com varias flores parnasianas nacidas de diversos engenhos, acumulandoas a este volume a curiosidade, para entertenimento do gosto. (Sem data). Braga: Biblioteca Pública de Braga, Ms.130, fl.124v.
} 
modelo da lírica seiscentista: Camões. ${ }^{94} \mathrm{~A}$ autoridade camoniana, associada ao exercício adequado da prática mimética e da espécie métrica em questão, fazem com que essa “definição do amor" seja um exemplar do gênero lírico nos anos Seiscentos, determinando, ao mesmo tempo, sua excelência.

A reflexão sobre as autorias - ou a falta delas - e a datação dos poemas também deve se estender às próprias compilações de poesia portuguesa seiscentista, em particular às duas mais conhecidas que, vale lembrar, foram publicadas apenas no século XVIII: a citada Fênix Renascida e o Postilhão de Apolo. Os cinco volumes da Fênix Renascida foram editados em Lisboa por Matias Pereira da Silva, entre 1716 e 1728, sendo que em 1746 foi publicada uma segunda edição aumentada. Já o Postilhão de Apolo é uma compilação ainda mais tardia, datando de 1762. Embora sejam relevantes fontes impressas para aqueles que se interessam pela poesia seiscentista portuguesa, essas duas coletâneas, quando cotejadas com outras compilações dos anos Seiscentos e Setecentos, tanto impressas como manuscritas, apresentam diversas atribuições de autoria e lições textuais questionáveis e, evidentemente, não encerram toda a poesia do século XVII que nos restou, não estando representados nelas muitos nomes de importantes poetas portugueses seiscentistas, ${ }^{95}$ além de, entre aqueles que são mencionados, faltar muita coisa da obra poética que poderia lhes ser atribuída. Mas alguns estudiosos já vêm desenvolvendo essas questões, propondo novas autorias e outras variantes textuais para muitos poemas dessas duas prestigiadas coleções de poesia seiscentista portuguesa.

Nesse sentido, é preciso destacar a importância de trabalhos como os de Maria de Lourdes Belchior Pontes, que em sua Bibliografia de António da Fonseca Soares (Frei António das Chagas) ${ }^{96}$ deu contornos mais precisos à obra desse poeta seiscentista. Além desse trabalho, não podemos nos esquecer do estudo de Vítor Manuel

\footnotetext{
${ }^{94} \mathrm{O}$ poema anônimo que citamos é uma imitação do soneto camoniano "Amor é um fogo que arde sem se ver; / É ferida que dói, e não se sente; / É um contentamento descontente; / É dor que desatina sem doer; / É um não querer mais que bem querer; / É um andar solitário por entre a gente; / É nunca contentar-se de contente; / É um cuidar que ganha em se perder; / É querer estar preso por vontade; / É servir a quem vence, o vencedor; / É ter com quem nos mata lealdade. / Mas como causar pode seu favor / Nos corações humanos amizade, / Se tão contrário a si é o mesmo Amor?". Vale ressaltar também que o último verso dessa "definição do amor" anônima - "He por fim hum naõ sey que, q̃ naõ entendo" - ecoa a última estrofe de uma outra composição atribuída a Camões, "Busque Amor novas artes, novo engenho": "Que dias há que na alma me tem posto / Um não sei quê, que na[s]ce não sei onde. / Vem não sei como, e dói não sei porquê." (Camões, L. de. Obra Completa, op.cit., p.270 e p.273).

${ }^{95}$ Vítor Manuel Pires de Aguiar e Silva dá diversos exemplos de poetas seiscentistas que não estão contemplados na Fênix Renascida (Maneirismo e Barroco na Poesia Lírica Portuguesa. Coimbra: Centro de Estudos Românicos, 1971, p.78).

${ }^{96}$ Pontes, M. de L. B. Bibliografia de António da Fonseca Soares (Frei António das Chagas). Lisboa: Centro de Estudos Filológicos, 1950.
} 
Pires de Aguiar e Silva, Maneirismo e Barroco na Poesia Lírica Portuguesa, no qual o autor, que analisou muitas fontes manuscritas de diversos arquivos e bibliotecas, apresenta uma grande quantidade de poemas seiscentistas que não se encontram nem na Fênix Renascida nem no Postilhão de Apolo. Aguiar e Silva, ao longo de toda sua obra, questiona também muitas atribuições de autoria (ou ausência dela) dessas duas compilações poéticas setecentistas; o "apêndice III" de seu livro, aliás, intitula-se “poesias de Sóror Violante do Céu incluídas como anônimas na Fênix Renascida". Por fim, vale mencionar também um trabalho mais recente: a edição, já citada, de Mafalda Ferin Cunha das Obras Poéticas de António Barbosa Bacelar, ${ }^{97}$ que reúne num único volume uma imensa quantidade de poemas que podem ser atribuídos a esse importante poeta português do século XVII, fundamental, principalmente, para o estudo da poesia lírica seiscentista.

No entanto, nesses trabalhos nota-se que os autores partem, quase sempre, de uma concepção de um sujeito-poeta, criador e criativo, com características psicológicoestilísticas individuais, e cujos textos devem ser identificados e autenticados. Essa busca pela autoria correta ou pela lição autêntica de um poema se mostra, na maior parte das vezes, pouco produtiva e sempre questionável. Os critérios para determinar a autenticidade dos textos e de seus autores, em se tratando da poesia portuguesa do século XVII, revelam-se, frequentemente, anacrônicos, a começar pela própria noção de "autenticidade" aplicada a essa produção retórico-poética. Por isso, diante de tal produção, baseada, sobretudo, em uma circulação oral e manuscrita dos poemas e exposta, constantemente, a variações textuais, parece inadequado aplicarem-se concepções de autor e de autoria, centradas na ideia de uma expressão subjetiva do indivíduo. Desse modo, em vez de autor e autoria, preferimos pensar em "autoridade" (auctoritas): uma noção que podemos encontrar nas artes retóricas e poéticas antigas. Os poetas seiscentistas buscavam nas autoridades retórico-poéticas tanto as regras como os melhores modelos ou exemplos para comporem seus poemas, seguindo sempre os preceitos do gênero em que compunham. Esse decoro do gênero implicava, entre outras coisas, o uso de palavras e conceitos mais adequados a cada tipo de composição, conforme os melhores modelos. No gênero lírico, por exemplo, os poetas seiscentistas portugueses tinham como principais modelos autoridades como Horácio, Ovídio, Petrarca, Garcilaso, Camões, Marino, Góngora etc., as quais imitavam para com elas

\footnotetext{
${ }^{97}$ Ver nota de rodapé n.21.
} 
poderem ser comparados. Sendo assim, podemos entender um pouco melhor a instabilidade do corpus da lírica camoniana. Como se sabe (e é bastante extensa a bibliografia sobre este tema), desde fins do século XVI, a obra lírica atribuída a Camões sofreu diversos acréscimos e cortes, sendo feitas muitas alterações de atribuição de autoria até se chegar àquilo que se julga, hoje em dia, "autenticamente" camoniano, com base em critérios e documentos que serão sempre questionáveis. No século XVII, o “Camões Lírico" não era visto como um "autor original”, mas sim como uma auctoritas da poesia lírica, ou seja, os poemas eram a ele atribuídos porque eram dignos de imitação: eram modelos que deviam ser seguidos com base em uma apreciação retóricopoética, isto é, fundamentalmente técnica, sendo indiferente se tinham sido, realmente, escritos pelo personagem histórico Camões.

Na poesia luso-brasileira do século XVII, a obra poética atribuída ao já referido nome "Gregório de Matos" também nos faz refletir sobre esse difícil emprego de concepções como "autor", "autoria", "originalidade" e "expressão subjetiva". Podemos lembrar, para exemplificar, dos trabalhos de João Adolfo Hansen, especialmente de seu livro A sátira e o engenho: Gregório de Matos e a Bahia do século XVII, em que mostra que tanto a poesia satírica atribuída a Gregório de Matos quanto a própria figura do poeta são, anacronicamente, julgadas revolucionárias, transgressoras, libertinas. Isso porque, como bem demonstra Hansen, tal sátira obedece aos preceitos retórico-poéticos e às convenções político-sociais que regulavam a produção (hoje dita) "literária" da época. Além disso, o que é importante destacar, no caso da poesia atribuída a Gregório de Matos, é que esses poemas circularam oralmente e em folhas volantes, sendo reunidos em diversos códices no final do século XVII e durante o século XVIII. A atribuição desses poemas a Gregório de Matos é apenas hipotética, funcionando tal nome como uma auctoritas da poesia lírica e, principalmente, satírica na Bahia no século XVII. Nesse sentido, vale a pena citar um trecho de um artigo de Hansen, intitulado "Barroco, Neobarroco e Outras Ruínas", 98 no qual, além de questionar o uso do termo "barroco" para designar a poesia seiscentista, faz a seguinte observação sobre a disposição dos códices que reuniram os poemas atribuídos a Gregório de Matos (em especial, o Códice Rabelo) e sobre o funcionamento da auctoritas do nome do poeta:

\footnotetext{
${ }^{98}$ In: REEL - Revista Eletrônica de Estudos Literários. Vitória, a.2, n.2, 2006, pp.1-60. Disponível em: http://www.ufes.br/ mlb/reel2/ JoaoAdolfoHansen.pdf.
} 
Quando os códices manuscritos são examinados, evidencia-se que neles a função-autor é o ponto de convergência das diversas versões de poemas que realizam a auctoritas do gênero retórico-poético do qual eles eram, para quem os juntou em códices nos séculos XVII e XVIII, outras aplicações. A autoria aparece, nos códices, não como realidade psicológica, mas como dispositivo discursivo. Ela decorre da aplicação de esquemas táticos, retóricos, pressupostos pela recepção contemporânea, ao menos pela recepção contemporânea letrada, que produzia e lia os manuscritos. No século XVII, ouvintes e leitores discretos também julgavam a arte com que as regras do dispositivo eram aplicadas, ao mesmo tempo que apreciavam a significação dos temas tratados. Desta maneira, no Códice Rabelo, a disposição dos poemas permite fazer do nome do poeta Gregório de Matos um dispositivo de designação de uma auctoritas lírica (sacra e profana) e também de uma auctoritas satírica (ridícula e maledicente). No caso, a autoria tem função classificatória, antes de funcionar como confirmação da origem dos poemas. Nesta perspectiva, Rabelo pôde coletar textos de fontes diferentes: por exemplo, paródias macarrônicas, que os estudantes de Coimbra faziam da poesia de Camões, que atribuiu a Gregório, ou trechos de poemas espanhóis, provavelmente de Lope de Vega, porque para ele o nome era antes um gênero que um autor individualizado. Reunindo sob a etiqueta Gregório de Matos todos os poemas que afirma ter coletado na oralidade e em folhas volantes, Rabelo constitui uma autoridade lírica e uma autoridade satírica.

Uma consequência lógica dessas incertezas quanto à atribuição de autoria é a dificuldade de datação precisa de muitos poemas que seriam, supostamente, de poetas do século XVII. Por isso, assim como a noção de auctoritas busca lidar com os problemas de autoria, chamar essa poesia de "seiscentista" é uma maneira de mostrar que, embora a maior parte dela tenha sido, provavelmente, composta no século XVII na Península Ibérica e em suas Colônias, o que nos interessa, mais do que a data exata de produção ou publicação dos poemas, é a predominância de modelos e procedimentos poéticos comuns. E como foi devidamente demonstrado por Maria do Socorro Fernandes de Carvalho, em seu já citado estudo Poesia de Agudeza em Portugal, os procedimentos poéticos comuns que norteiam grande parte dessa variada poesia seiscentista determinam uma poética específica, centrada na noção de "agudeza". Esse 
termo, que é fundamental para se pensar na especificidade da poesia seiscentista, foi definido e debatido em tratados retóricos e poéticos do século XVII, tais como Delle Acutezze de Matteo Peregrini, Agudeza y Arte de Ingenio de Baltasar Gracián e Il Cannocchiale Aristotelico de Emanuele Tesauro. Gracián assim define a agudeza: "Consiste, pues, este artificio conceptuoso en una primorosa concordancia, en una harmónica correlación entre dos o tres cognoscibles extremos, expresada por un acto del entendimiento". A essa definição é importante acrescentar a noção de concepto: "Es un acto del entendimiento, que exprime la correspondencia que se halla entre los objetos". 99

Na preceptiva seiscentista que trata da agudeza, são retomadas e recicladas, principalmente, as lições aristotélicas do livro III da Retórica, relativo à elocução, e do capítulo XXI da Poética, no qual se discute a concepção de metáfora. Esta, segundo Aristóteles, "consiste no transportar para uma coisa o nome de outra, ou do gênero para a espécie, ou da espécie para o gênero, ou da espécie de uma para a espécie de outra, ou por analogia" (Poética, XXI, 1457b, 6-7). Portanto, a metáfora, fonte por excelência de ensinamento e deleite, evidencia a semelhança entre as coisas. $\mathrm{O}$ poeta é aquele que descobre tal semelhança e que a exprime com palavras adequadas. ${ }^{100}$ No século XVII, com base nos preceitos aristotélicos, acentua-se a superioridade da metáfora como o meio mais eficaz de deleitar e instruir, e ela passa a ser considerada, então, "fundamento da agudeza e, de modo geral, de toda representação". ${ }^{101}$

Além disso, Aristóteles também ressalta, na Retórica, que a metáfora não deve provir de coisas que apresentem semelhanças muito óbvias: “é forçoso que as metáforas provenham de coisas apropriadas, mas não óbvias, tal como na filosofia é próprio do espírito sagaz estabelecer a semelhança mesmo com entidades muito diferentes" (Retórica, III, 1412a). Os poetas seiscentistas, explorando ao máximo a lição aristotélica, buscam estabelecer relações entre conceitos extremos, condensando-os em metáforas agudas que são fontes de proveito e maravilhamento para os leitores.

O debate sobre a agudeza no século XVII depende dos preceitos retóricos e poéticos antigos, não apenas de Aristóteles, mas de diversos outros autores gregos e

\footnotetext{
${ }^{99}$ Gracián, Baltasar. Agudeza y Arte de Ingenio (Discurso II. "Esencia de la Agudeza Ilustrada". Huesca, Juan Nogués, 1648, p.7). Edición facsímil. Estudio preliminar de Aurora Egido. Zaragoza: Institución «Fernando el Católico», 2007.

100 "Grande importância tem, pois, o uso discreto de cada uma das mencionadas espécies de nomes, de nomes duplos e de palavras estrangeiras; maior, todavia, é a do emprego das metáforas, porque tal se não aprende nos demais, e revela portanto o engenho natural do poeta; com efeito, bem saber descobrir as metáforas, significa bem se aperceber das semelhanças" (Poética, XXII, 1459a, 4-8).

${ }^{101}$ Hansen, J. A. "Retórica da Agudeza", op.cit., p.321.
} 
latinos, em especial Cícero e Quintiliano. Essa preceptiva antiga está na base da agudeza seiscentista que, como dissemos, é a noção que nos permite reunir a variedade poética do período. Como analisa Maria do Socorro Fernandes de Carvalho, a agudeza é

termo aglutinador da diversidade poética que compõe os carmina minora seiscentistas, tanto em termos da profusão das espécies de versos, quanto das convenções poéticas múltiplas que os conformam. Obras de Baltasar Gracián na Espanha, e de Matteo Peregrini e Emanuele Tesauro na Itália, a despeito de suas diferenças, defendem a especificidade da metáfora aguda e também a denominação de agudeza para essa produção retórico-poética. ${ }^{102}$

Aguda, por exemplo, é a poesia de Manuel Botelho de Oliveira, como bem o demonstra Ivan Teixeira em seu "estudo crítico" que antecede a edição fac-similar de Música do Parnaso. ${ }^{103}$ Além disso, como também salienta Teixeira, é preciso cuidado ao se considerar essa obra de Botelho de Oliveira "brasileira" (obra, aliás, que foi publicada em Lisboa em 1705). O poeta, embora tenha nascido no Brasil, estudou em Coimbra e, como podemos verificar no frontispício de seu livro, era caracterizado como integrante da fidalguia portuguesa. Os poemas de Música do Parnaso foram escritos em quatro diferentes idiomas (português, castelhano, italiano e latim) e confundiam-se com seus modelos europeus. Enfim, "redigida a partir de um ponto identificado como 'América', a dedicatória do livro [Música do Parnaso] destina-se à nobreza da casa de Bragança, representada em D.Pedro II (1683-1706), a quem o autor chama 'nosso monarca'. Embora se considere 'filho do Brasil', o poeta - entendido sempre como sujeito da enunciação - pensava e escrevia como europeu, tendo composto apenas trinta por cento do seu livro em português, aproximadamente". ${ }^{104}$ Nesse mesmo sentido, podemos evocar a análise retórico-poética que Adma Muhana fez de uma das mais conhecidas e debatidas composições de Música do Parnaso, a silva “À ilha de Maré”, que foi considerada por muitos um poema nativista "brasileiro". Como assinalado por Muhana, essa silva de Botelho de Oliveira segue, rigorosamente, os preceitos retóricopoéticos para tecer seu elogio à ilha de Maré e compõe a imagem dessa ilha da Bahia a

\footnotetext{
${ }^{102}$ Carvalho, M. S. F. de. Poesia de agudeza em Portugal, op.cit., p.29.

103 Teixeira, I. “A poesia aguda do engenhoso fidalgo Manuel Botelho de Oliveira”, op.cit., pp.11-96.

${ }^{104}$ Idem, p. 13.
} 
partir de fontes poéticas como Marino e Camões, tornando-se difícil, portanto, sustentar-se uma visão "nativista" ou "nacionalista" acerca de tal composição:

A imagem da ilha de Maré na silva de Botelho de Oliveira tem como fontes, que contrafaz, o "jardim das delícias" da ilha de Chipre, morada de Vênus, no canto VII do Adone de Marino, bem como a "ilha dos amores", no canto IX d'Os Lusíadas de Camões. Porém, todos os confrontos entre as delícias da ilha do Recôncavo e aquelas encontradas nas outras partes do mundo dos antigos, cujo paragone resulta sempre na superioridade dos elementos presentes em Maré, estão emoldurados pelo cotejo final entre a deusa do amor pagã e a do amor cristão, com predomínio, evidente, da última, melhor deusa do amor, porque verdadeira, de nome derivado do próprio mar, "maria" (...). Por isso, o poema todo há de ser lido como uma comparação epidítica que não visa senão ao elogio da ilha da Bahia, mostrada como uma maravilha, cuja sobrenaturalidade é fruto da bênção divina. (...) Para tanto, Botelho de Oliveira segue rigoroso as recomendações de Quintiliano acerca da demonstração epidítica de um locus... ${ }^{105}$

Assim, enquanto poesia europeia seiscentista, a obra de Botelho de Oliveira é enformada pelos preceitos da agudeza, como se verifica em uma de suas agudas décimas, "Cravo na boca de Anarda": 106

Quando a púrpura fermosa

Desse cravo, Anarda bela,

Em teu céu se jacta estrela,

Senão luzente, olorosa;

Equivoca-se lustrosa,

(Por não receber o agravo

De ser nessa boca escravo)

Pois é, quando o cravo a toca,

O cravo, cravo da boca,

A boca, boca de cravo. ${ }^{107}$

\footnotetext{
${ }^{105}$ Muhana, A. Introdução". In: Oliveira, M. B. de. Poesia completa: Música do Parnasso, Lira Sacra, op.cit., pp.LXXVIII-LXXIX.

${ }^{106}$ Essa décima de Botelho de Oliveira foi minuciosamente comentada por Ivan Teixeira ("A poesia aguda do engenhoso fidalgo Manuel Botelho de Oliveira", op.cit., pp.24-33).
} 
Como apontado por Ivan Teixeira, essa tópica da ninfa com uma flor na boca, tão explorada pelos poetas do século XVII, é referida na Nova Arte de Conceitos de Francisco Leitão Ferreira:

Se, pois, se propusesse louvar a Rosa estando na boca de uma Ninfa, seria proposição complexa, porque envolveria dois objetos diferentes e correlatos, Rosa e Ninfa, e ligá-los-ia a circunstância acidental e única de estar na boca: de maneira que, sem aquela circunstância, que também entra como objeto, faltaria ao assunto a sua integridade, destruir-se-ia a composição do todo e separadas as partes principais, Ninfa e Rosa, seriam objetos distintos, e não extremos identificados, ficariam independentes, e não correlativos, e constituiriam singelamente dois assuntos, com diversos fins e especiais conceitos. (...) da mesma sorte, a circunstância que ligar os objetos de uma proposição, faz com que se prediquem de um as propriedades e noções de outro. ${ }^{108}$

Na décima de Botelho de Oliveira, Anarda e o cravo são objetos extremos identificados através de metáforas agudas, que conduzem o leitor ao efeito inesperado e engenhoso dos dois últimos versos. O cravo, gabando-se de ser estrela perfumada no rosto ("céu") de Anarda, é obrigado a confundir-se ("equivoca-se") com a boca da donzela, para evitar a ofensa de se ver preso e inferiorizado ("escravo") entre lábios tão belos. Assim, nos versos finais do poema, os objetos antes distintos (Anarda e a flor) tornam-se idênticos, empregando-se um quiasmo que acentua o equívoco dos vocábulos: o cravo é boca e a boca é cravo; equívoco que também se estende às suas propriedades, embora fique evidente que se a flor é "púrpura fermosa" e "estrela olorosa", a boca de Anarda é púrpura ainda mais bela e é estrela muito mais perfumada e luzente, pois foi o cravo que precisou se fundir a ela para não ser "escravo". Vale ainda ressaltar que a inferioridade da flor também se evidencia no uso da paronomásia: a semelhança física entre os vocábulos "cravo" e "escravo" indica, por conseqüência, a similaridade de seus significados, já que, como afirma Gracián, “es como hidra vocal

${ }^{107}$ Citamos o texto com base na edição de Adma Muhana da "poesia completa" de Manuel Botelho de Oliveira (Poesia completa: Música do Parnasso, Lira Sacra, op.cit., p.46). Mas utilizamos também a primeira edição da Música do Parnaso, de 1705 (Música do Parnaso. Edição fac-similar [1705-2005], op.cit., p.24).

${ }^{108}$ Nova Arte de Conceitos. Primeira parte, op.cit., pp.317-318. 
una dicción, pues a más de su propria y directa significación, si la cortan o la trastruecan, de cada sílaba renace una sutileza ingeniosa y de cada acento un concepto". 109

A mesma situação da ninfa com uma flor na boca é glosada nas décimas "A uma dama que tinha um cravo na boca", atribuídas a Gregório de Matos. Embora semelhantes ao poema de Botelho de Oliveira, as décimas do suposto Gregório de Matos acentuam a superioridade da boca da dama em relação ao cravo, e não a "troca" de suas propriedades: "Vossa boca para mim / não necessita de cravo, / que o sentirá por agravo / boca de tanto carmim: / o cravo, meu serafim, / (se o pensamento bem toca) / com ele fizera troca: / mas, meu bem, não o aceiteis, / porque melhor pareceis, / não tendo o cravo na boca." Afinal, como se conclui na segunda décima, menina tão bela já tem sempre "boca de cravo". ${ }^{110}$ Além dessas décimas, podemos lembrar de um soneto de António Barbosa Bacelar que trata da mesma tópica: "A uma dama que colhendo um cravo o chegou à boca, onde o despedaçou". Variando o tema, a persona lírica elogia a boca da dama de forma antitética, ressaltando a "sorte" do cravo que teve uma tão doce morte: "No te pese clavel porque moriste, / Ya que lograste con tu breve vida / La dicha de tener tan dulce muerte". ${ }^{111}$

Nesses três poemas, o elogio da beleza e da graça de cada parte do corpo da dama (no caso, a boca) indica a perfeição do todo, cuja harmonia torna visível a virtude, retomando-se, numa perspectiva cristã, a concepção platônica do belo como análogo do bem. Isso porque, na lírica amorosa de Manuel Botelho de Oliveira ou, ainda, da Fênix Renascida, "as metáforas emulam intelectualmente as imagens da lírica petrarquista, camoniana e gongórica, compondo a beleza física da dama como análogo sensível da beleza espiritual". ${ }^{112}$ Porém, o amor da poesia seiscentista é agudo e múltiplo: se, por um lado, é virtude que deleita e ensina, por outro, é paixão que perturba quem está a ela

\footnotetext{
${ }^{109}$ Agudeza y Arte de Ingenio. Discurso XXXI. "De la Agudeza Nominal”, op.cit., p.215.

110 "Quanto mais que é escusado / na boca o cravo: porque / prefere, como se vê / na cor todo o nacarado: / o mais subido encarnado / é de vossa boca escravo: / não vos fez nenhum agravo / ele de vos dar querela, / que menina, que é tão bela, / sempre tem boca de cravo." (Gregório de Matos. Obra Poética, op.cit., p.900).

111 "Coge Lisi la purpura olorosa / De un clavel rojo, en su blanca mano, / Prisionando la pompa del Verano / En grillos de marfil, prisión dichosa. / Al carmín llega de su boca hermosa / El clavel puro, entonces más lozano / De ver que aprende de rustico aldeano / Rojo primor en grana más preciosa. / Flor dichosa que tal lisonja diste / Al vivir breve de tu edad florida, / Con merecer tu fin tan bella suerte! / No te pese clavel porque moriste, / Ya que lograste con tu breve vida / La dicha de tener tan dulce muerte.”(Bacelar, A.B. Obras Poéticas, op.cit., 2007, p.534).

${ }^{112}$ Hansen, J. A. "Fênix renascida \& Postilhão de Apolo: Uma introdução", op.cit., p.68.
} 
sujeito. ${ }^{113}$ No madrigal "A uma crueldade formosa" de Jerônimo Baía, ${ }^{114}$ por exemplo, a beleza e o rigor da dama causam sofrimento na persona lírica, que se deixa afetar por uma formosura tão cruel. Essa "crueldade formosa" se evidencia na descrição do corpo da amada, sendo cada parte dele associada a diferentes metais e pedras, que embora sejam "preciosos", são também "duros": o cabelo é ouro, a frente é prata, o coração é bronze, o peito é aço, os olhos são celestial "safiro", os beiços são "rubins", os dentes são "perlas", a garganta é mármore polido, a mão é jaspe e a "planta" é alabastro. A beleza dessas pedras e metais preciosos, ou melhor, dessas "feições milagrosas" se iguala aos seus duros desdéns, e se há "tanta lindeza" e "tal rigor" em cada parte do corpo, o todo é ainda mais formoso e muito mais cruel. Por isso, na circunstância desse poema, a dama é detestada ${ }^{115}$ e chamada de "bela ingrata", mostrando-se a persona lírica sujeita ao amor-paixão.

Assim, nota-se que a aguda poesia lírica seiscentista não só deleita, mas também ensina. No caso da lírica amorosa, imitam-se afetos amorosos seja para purgar o excesso das paixões, seja para servir como exemplos da virtude; de qualquer modo, o que se busca é mover os ânimos dos leitores ou ouvintes, deleitando-os e instruindo-os.

Nesse sentido, o Trattato della poesia lirica de Pomponio Torelli, que já nos foi fundamental para o debate sobre as especificidades da imitação lírica, também é uma importante fonte para a discussão acerca da finalidade da poesia lírica. Desse modo, segundo Torelli, a finalidade da lírica só pode ser compreendida se, primeiro, for compreendido o fim (controverso) de toda a poesia, já que aquela é uma espécie desta. ${ }^{116}$ Para tratar desse assunto, que se centra na questão de se saber se a finalidade da poesia é o deleite e/ou a utilidade, o autor ancora-se em autoridades antigas, como Aristóteles, Platão e Horácio, e modernas, especialmente Robortello.

\footnotetext{
${ }^{113}$ Utilizamos o termo "paixão" na acepção predominante da época, isto é, como uma "perturbação" tanto do corpo quanto da alma.

114 "A minha bela ingrata / Cabelo de ouro tem, frente de prata / De bronze o coração, de aço o peito, / São os olhos luzentes, / Por quem choro, e suspiro / Desfeito em cinza, em lágrimas desfeito, / Celestial Safiro: Os beiços são rubins, perlas os dentes, / A lustrosa garganta / De mármore polido, / A mão de jaspe, de alabastro a planta, / Que muito pois, Cupido, / Que tenha tal rigor, tanta lindeza, / As feições milagrosas / Para igualar desdéns a formosuras / De preciosos metais, pedras preciosas, / E de duros metais, de pedras duras." (A Fenix Renascida ou obras poeticas dos melhores engenhos portuguezes. Tomo III. Segunda vez impresso e acrescentado por Mathias Pereira da Sylva. Lisboa: Offic. dos Herd. de Antonio Pedrozo Galram, 1746, p.216).

${ }^{115}$ Veja-se também a análise que Adma Muhana faz do madrigal "Conveniências do rosto, e peito de Anarda", de Manuel Botelho de Oliveira ("Introdução". In: Poesia Completa, op.cit., pp. LVII-LVIII).

116 "Ma perché la lirica è spezie della poesia, mal si potrà intendere il fine di questa se del fine di tutta la poesia, del quale gran controversia è tra' dotti, prima non disputeremo." (Torelli, P. Trattato della poesia lirica, op.cit., p.2).
} 
De acordo com Torelli, baseando-se em Aristóteles e Horácio, como a poesia é imitação da vida humana e o fim da vida sempre foi considerado "dúbio" (dubbio) pelos mais sábios filósofos, "così bisognava che si contrastasse sopra il fine della poesia che l'immita". ${ }^{117}$ Assim, uma primeira opinião apresentada sobre a finalidade, dúbia e muito discutida, da poesia é aquela de Robortello, para quem o fim próprio do poeta seria o deleite:

Robortello, uomo dottissimo e mio maestro, nel prologo ch'egli fa al suo commento sopra la Poetica d'Aristotele, determina essere il fine del poeta il dilettare, ancor ch'egli giovi ancora; poi soggiunge che altro fine non ha il poeta che dilettar gli animi con rappresentare, descrivere, et immitare tutte l'azioni umane, tutti i moti, e tutte le cose tanto animate quanto inanimate, e doppo inferisce il fine del poeta essere il parlar che immita, né immitar altro che l'azioni esteriori che dagli abiti interiori derivano. Dove appare doi fini porsi dal Robortello, poiché '1 parlar che immita non è lo istesso che 'l dilettare, ma la bona immitazione sarà ben causa del diletto ch'egli in quel loco come fine ci propone, senza addurre altra ragione $\mathrm{o}$ autorità. ${ }^{118}$

Ainda conforme Robortello, o deleite é causa final da poesia, enquanto a imitação é causa eficiente, visto que Aristóteles afirma que são duas as causas das quais deriva a poesia: uma é o imitar que é coisa naturalissima aos homens, no que se diferem de todos os outros animais, e fazem esse exercício desde a infância (mais exatamente, prima fanciulezza) sem mestre; e a outra é o deleite que, naturalmente, o homem sente na imitação. Para alcançar o seu fim de deleitar, é bastante conveniente ao poeta a "maravilha" (meraviglia), porque ela é "deleitável” (dilettevole) e, prova disso, é que todos aqueles que narram as coisas para deleitar, engrandecem-nas ao fazê-las, por isso, maravilhosas. "Onde pare che ' 1 scopo del poeta sia il diletto, e perciò essi dicono che la meraviglia fa che il poeta ottenghi il suo fine". 119

Enfim, nesse primeiro ponto de vista sobre a disputada questão da finalidade da poesia, conclui-se que "altro che diletto non ha per fine la poesia". ${ }^{120}$ Portanto, exclui-se a utilidade. A principal autorità (essa palavra é usada frequentemente no texto, tanto

\footnotetext{
${ }^{117}$ Idem, p.2.

${ }^{118}$ Idem, p.2.

119 Idem, p.3.

${ }^{120}$ Idem, p.4.
} 
associada a "autores" antigos e modernos como aos seus argumentos) que confirma tal posição é Platão, que no oitavo diálogo da República expulsa os poetas, não porque não fossem bons poetas, mas porque não eram úteis ao governo da República, já que servindo à sua finalidade própria, que é o deleite, contrastavam com a utilidade pública. ${ }^{121}$

No entanto, outras autoridades, tais como o próprio Aristóteles e Cícero, permitem Torelli ressalvar que não há prazer que em si mesmo não seja útil: "non sarà piacere alcuno che per fine non risguardi ad altro e che in se stesso utile non sia". ${ }^{22}$ Ainda segundo Torelli, Robortello, que serviu como fonte para se afirmar, num primeiro momento, a prevalência do deleite sobre a utilidade, contradizendo-se ou emendando-se no mesmo prólogo mencionado anteriormente, diz que como há diversas sortes de composição, há também diversas sortes de utilidade, e defendendo a opinião de Estrabão contra a de Eratóstenes, sustenta que os poetas são mestres e "corretores" (correttori) da vida. A autoridade de Horácio é também alegada para confirmar essa condição do deleitar instruindo, sendo referidos aqueles dois conhecidos versos horacianos: "Et prodesse volunt et delectare poetae" (Epistola ad Pisones, v.333) e "Omne tulit punctum qui miscuit utile dulci” (Idem, v.344).

O principal fundamento, porém, dessa “opinião" (opinione) é, nas palavras de Torelli, “l'autorità d'Aristotele" que, na sua definição da tragédia, conclui que por meio da compaixão e do terror purgam-se os "ânimos" (animi) de perturbações e paixões. Isso porque, "la poesia è arte, ogni arte è indrizzata al bene, dunque la poesia deve risguardar no 'l diletto ma il vero bene". ${ }^{123}$ Especificando um pouco mais, o deleite seria o fim com relação ao imitar e no que diz respeito ao purgar os ânimos, ele seria o meio. Nesse sentido, sintetiza o preceptista italiano, parecendo assumir a seguinte posição: "Noi concediamo che 'l diletto accompagna ogni spezie di poesia, come l'ombra ogni corpo; ma come mezzo, non come fine. Che l'immitazione et il verso ci rechino diletto, si concede; ma a questo diletto essenzialmente è congionta e ne segue l'utilità che di sopra abbiamo detto." Por isso, à autoridade de Platão, deve-se ressaltar que ele não expulsou nem repreendeu os poetas porque seu fim fosse o deleite, mas porque os

\footnotetext{
121 'Confermano ciò con l'autorità di Platone, tanto stimato che e principe e dio de' filosofi fu chiamato, il quale nell'ottavo dialogo della Republica scaccia i poeti, non perché buoni poeti non fossero ma perché non erano utili allo stato della republica, perché servendo al lor fine, ch'è 'l diletto, contrastavano all'utile publico." (Idem, p.4).

${ }_{122}$ Idem, p.5.

123 Idem, p.6.
} 
ignorantes, deslumbrados pelo deleite, não distinguiam a verdadeira luz da poesia: a honestidade.

Outra questão acrescentada ao debate acerca da finalidade da poesia é a noção aristotélica de virtude: uma arte será tanto mais nobre quanto mais seu fim se aproximar da virtude, por meio da qual se pode alcançar a felicidade.

Determina Aristotele nei suoi libri dell'Etica la mondana felicità non consistere in altro che nell'operazioni secondo la virtù, onde questa istessa virtù, che altri si avea tolta per fine, egli si tolse per mezzo di poter acquistar la felicità. (...) Ha dunque l'arte principalissima, secondo Aristotele, il suo fine ch'è la felicità et il suo mezzo ch'è ogni sorte di virtù, e però l'altre arti sottoposte a lei avranno o le virtù per fine o fine che alle virtù s'appartenghi. E quanto un fine d'un'arte sarà più prossimo alle virtù, tanto quell'istessa arte più alla principalissima s'accosterà, e per conseguenza più nobile dovrà essere riputata. ${ }^{124}$

Além disso, Torelli destaca que na concepção aristotélica da poesia é por intermédio dos afetos que se tempera o afeto, ora usando um afeto contrário àquele que se quer moderar, ora tornando menor (minore) o próprio afeto a ser temperado, como na tragédia que, através da misericórdia e do terror, purgam-se os mesmos terror e misericórdia. Os afetos, portanto, não devem ser expulsos, mas reduzidos como meio da poesia, pois assim podem servir à virtude. Com base nessas noções, ampliando-se aquilo que já tinha sido exposto anteriormente no tratado, define-se o fim útil da poesia segundo Aristóteles: purgar o ânimo (animo) das paixões com as próprias paixões, por meio do deleite, e deleitando e comovendo os afetos, reduzir os afetos à mediocridade. $^{125}$

Discorre-se, em seguida, sobre a finalidade da poesia na concepção platônica. Desse modo, o furor poético resgata a alma (anima) de sua condição terrena - portanto, miserável, letárgica e estéril -, na qual se encontra cindida, e faz isso excitando suas partes débeis, temperando-a com a doçura e, com a harmonia, reduzindo-a à concórdia. O fim da poesia, de acordo com Platão, é justamente esse de temperar as partes da alma e, sendo esta discordante em si mesma, reduzi-la a uma unidade harmônica. Assim, vê-

\footnotetext{
${ }^{124}$ Idem, pp.9-10.

125 "purgar l'animo dalle passioni con l'istesse passioni, col mezzo del diletto, e dilettando e commovendo gli affetti, ridur gli affetti a mediocrità." (Idem, p.10).
} 
se que o furor divino, que introduz nos ânimos (animi), deleitando-os, a harmonia, não é outro senão o ofício e fim da poesia de reduzir os afetos à mediocridade e purgar os ânimos (animi), por meio do deleite, do excesso das perturbações, que é aquilo que foi dito com base em Aristóteles, e o furor poético, proveniente do favor das musas, suscita e edifica a alma (anima), que é aquilo que tratou Platão no Fédon na figura de Sócrates e que é confirmado no Fedro. ${ }^{126}$

Outro tema interessante discutido no Trattato della poesia lirica é a divisão do deleite platônico segundo as partes da alma. Desse modo, sendo três essas partes irascível, concupiscível e aquela que aprende (impara) - e, por isso, três os desejos ou vontades (desiderii) - os da honra, os carnais e os de aprender (imparare) -, convém que sejam três os deleites, entre os quais, será próprio e verdadeiro o deleite que na verdadeira parte da alma consiste e do verdadeiro desejo nasce. Platão, portanto, que buscava que os homens provassem o verdadeiro deleite, não expulsou os poetas porque eles se propuseram o deleite como fim, mas porque servindo ao falso deleite, julgado pelos ignorantes como bom, não serviram com o intuito de obter o verdadeiro. Essa apreciação equivocada do deleite pode ser resultado de um também falho julgamento de seu objeto (oggetto). No Fedro, o objeto do prazer (piacere) é definido como o belo, e as belezas são três: de ânimo (d'animo), de corpo e de discurso (d'orazione); resultando, assim, nos três desejos e deleites. O verdadeiro deleite, enfim, é alcançado quando, com um belo discurso, se celebram os belos efeitos (effetti) que realiza um belo ânimo (animo) por meio de um belo corpo; e o exemplo citado de poeta que reúne essas três belezas em seus versos e que, dessa forma, logra o "vero diletto" é Petrarca.

Para concluir o assunto em questão, afirma Torelli: "Poiché dunque i poeti tristi, secondo Platone nel Gorgia, perturbano gli animi con l'esca del piacer falso, i boni con il mezzo del piacer vero acqueteranno e fermeranno le discordanti passioni, come vole Aristotele". 127

Depois de discutir o fim universal da poesia, o Trattato della poesia lirica volta-se, então, para a finalidade específica da lírica. Assim, Torelli afirma que o maior poeta lírico que compôs em latim foi Horácio, o que indica a importância dessa autoridade latina para a lírica seiscentista (ainda mais se lembrarmos que, como já

\footnotetext{
126 "Onde si vede che 'l furor divino, che introduce negli animi con dilettarli l'armonia, altro non è se non ch'è l'officio e fine della poesia di ridur gli affetti a mediocrità e purgar gli animi col mezzo del diletto dal soverchio delle perturbazioni, ch'è quello che abbiamo detto di sopra di mente d'Aristotele, e quello che Platone toccò nel Fedone in persona di Socrate e quello che lo istesso nel Fedro conferma, che 'l furor poetico, che per favor delle muse proviene, suscita et inalza l'anima.” (Idem, p.11).

${ }^{127}$ Idem, p.13.
} 
citado, no Vocabulário Português e Latino de Bluteau, o "poeta lírico", por antonomásia, é justamente Horácio). E os versos horacianos (Epistola ad Pisones, vv.83-85), que mencionamos anteriormente ${ }^{128}$ e que determinam as matérias adequadas à "lira", são usados por Torelli para dar início à discussão sobre a finalidade particular da poesia lírica. Tais versos levam o preceptista italiano a questionar como pode haver unidade de fim em uma "arte" com matéria tão diversa. Para ele, essa questão se resolve se recordarmos que a poesia tem uma finalidade universal que, como já exposto, é reduzir os afetos à mediocridade purgando o excesso das paixões, conforme Aristóteles, e unir as partes discordantes da alma para reconduzi-la a Deus, segundo Platão. A esse fim universal, todas as espécies de poesia necessariamente aspiram e dele, enquanto princípio, dependem. ${ }^{129}$ Além disso, como ficou demonstrado nas duas primeiras lições do tratado, todas as espécies de poesia têm, em comum, o prazer (piacere) como “acidente inseparável” (accidente inseparabile).

Embora Aristóteles não tenha discorrido sobre a lírica, para Torelli, ela é espécie perfeita de poesia e, consequentemente, é perfeito o poeta lírico, que deve ser conduzido de princípio perfeito a perfeito fim. E se a poesia, como sugere Platão, é uma corrente com a qual Deus puxa para si o poeta e, através do poeta, também quem o escuta ou lê, a lírica é, com propriedade, essa corrente, já que uma de suas partes é exatamente aquela que contém Deus e seus louvores. Portanto, o poeta lírico louva, e louva principalmente Deus; não louvaria Deus se não fosse dele inspirado, e inspirado, é posto fora de si, ou melhor, alçando-se sobre si, une-se a Deus. Mas não pode o vulgo compreender essas (e outras) alegorias poéticas, nem é bom que ele compreenda todas as coisas. Por isso mesmo, "non è, secondo Massimo Tirio, altro la poesia che una secreta filosofia". 130

Retomando, porém, o debate sobre a finalidade dos líricos, Torelli, recorrendo mais uma vez a Aristóteles, declara que também buscam eles, como os demais poetas, aquietar (acquetare) os ânimos, contendo as paixões. Isso parece óbvio quando se pensa na parte da lírica, de acordo com a divisão horaciana, que tem como objetivo louvar os deuses e os heróis; no entanto, quando se considera a outra parte da lírica, que trata dos

\footnotetext{
${ }^{128}$ Ver nota de rodapé n. 18.

129 "Nella precedente lezione dunque concludemo ch'altro non intendeva la poesia che di ridur gli affetti alla mediocrità con purgar l'eccesso delle passioni, e questo affirmamo essere inteso da Aristotele e convenirsi con quanto ne disse Platone, ch'era insomma che la poesia non cercava altro che di unire le discordanti parti dell'anima per ridurla a Dio. A questo fine universale tutte le spezie di poesie forza è che aspirino, e da lui come principio dependino." (Trattato della poesia lirica, op.cit., p.14).

${ }^{130}$ Idem, p. 16 .
} 
amores, que imita atos lascivos, cujo assunto (soggetto) são banquetes, vinho, querelas de excluídos, desespero dos desprezados, tal finalidade se mostra menos evidente. Esclarece, então, o preceptista italiano que a lírica amorosa é também útil, pois purga os ânimos das mesmas paixões das quais é plena: "Dico che questa parte giova ancora essa, e giova a purgar gli animi dall'istesse passioni delle quali è tutta piena". ${ }^{131}$

Assim, se, como ensina Platão, a imitação quanto ao efeito não é a própria coisa, distando o imitador do verdadeiro (vero) como aquele que é o terceiro em relação à verdade (verità), a juventude, ao ler os poetas, estará tanto mais distante do vício quanto mais segura, porque conversará não com os viciosos, mas com os representadores dos vícios (rappresentatori dei vizii). Torelli desenvolve essa afirmação depois de citar Catullo: ${ }^{132}$ vendo a juventude a deformidade do vício retratada na representação, mais facilmente se armará para resistir-lhe e melhor conseguirá desprezálo, tendo, enfim, horror a ele. Esta é a utilidade da representação dos vícios da lírica: ensinar com o exemplo (l'imparare con l'essempio). Por isso, a finalidade dos poetas amorosos, sendo Petrarca a autoridade mencionada, é expulsar dos nossos ânimos o excesso desta paixão amorosa, que é o amor lascivo, imitando esses poetas suas paixões, embora seja tal imitação "feita em universal" (fatta in universale), isto é, segundo o verossímil de um ardente amante. Torelli define, portanto, a finalidade dos poetas líricos: "È adunque il fine dei lirici di purgar l'eccesso delle passioni col mezzo del diletto, che dall'immitazione dell'istesse passioni e costumi degli appassionati ci proviene". 133

Não podemos esquecer, porém, que esse debate sobre a finalidade da poesia está relacionado com uma importante discussão retórica, também profusa em fins do século XVI, acerca dos três ofícios do discurso, em particular, sobre o equilíbrio entre delectare e docere. Guido Morpurgo Tagliabue, em seu texto Aristotelismo e Barocco, afirma que, desde o século $\mathrm{XV}$, a retórica foi sendo reduzida à elocutio, ao ornato, ao deleite, excluindo-se da techne rhetorike a inventio e, consequentemente, o ensinamento. Essa tendência de restringir a "arte" ao ornato teria levado, no século XVI, a uma "crisi del Rinascimento", que caberia ao século XVII (para o autor, o "Barroco") tentar resolver, conciliando o delectare e o docere:

\footnotetext{
${ }^{131}$ Idem, p.16.

${ }^{132}$ Eis os versos referidos no Trattato della poesia lirica: "Nam castum esse decet pium poetam, / Ipsos versiculos nihil necesse est / Qui tum denique habent salem ac leporem / Si sunt molliculi ac parum pudici" (Idem, p.17).

${ }^{133}$ Idem, p.17.
} 
Il Barocco non è una riduzione dell'oratoria e della poesia e dell'arte al semplice e al superficiale. Anche gli aspetti più frivoli e lucenti del barocco non sono mai semplici. Ciò che appare futile e parziale, del Barocco, tende a recuperare la propria integralità mercè una dialettica interna, che lo fa complesso e sofistico. Quella intrinseca dialletica era imposta dalla problematica della cultura di fine secolo, che abbiamo conosciuta. Della antinomie, alle quali il tardo Rinascimento era pervenuto in ogni campo. E qualcuna ne abbiamo veduta: l'antinomia tra il trionfo e la condanna della retorica, e cioè tra una concezione autonoma e una eteronoma della oratoria; e l'antinomia tra una estrema elaborazione stilistica dell'arte figurativa e l'istanza che essa suscitava, presso i manieristi, di un rinnovato appello all'universale, all'idea; infine l'antinomia tra una concezione hedonística e una concezione pedagogica della letteratura. Tutti aspetti che possiamo esprimere con l'antitesi tra il delectare e il prodesse, portata a maturazione dal clima della controriforma; e la cui origine è da cercare in quel declino dell'inventio, in quella crisi degli endoxa, di cui abbiamo parlado. Gli «endoxa» sfuggono all'inventio, e non sono più per il letterato un patrimonio convenuto, ma un compito, una scelta, un problema, talvolta una questione di conformismo o di eterodossia o di libertinismo. Questa la natura della crisi che porta un dislocarsi dell'espressione oratoria e poetica. ${ }^{134}$

Todavia, quando se trata, em particular, da poesia seiscentista, é destacado, frequentemente, o lugar central do "prazer do ornamento", como o faz João Adolfo Hansen:

Este funcionamento retórico da poesia antiga (...) muda quanto à clareza e à congruência em fins do século XVI e no século XVII, na poesia que hoje se conhece por "barroca": o prazer do ornamento torna-se então central, o episódico passa a ser proposto como fundamental, a incongruência e a obscuridade se fazem programáticas. Em outros termos, a elocução e seus ornamentos passam a preencher os lugares

134 Tagliabue, G.M. "Aristotelismo e Barocco". In: Retorica e Barocco. Atti del III Congresso Internazionale di Studi Umanistici. A cura di Enrico Castelli. Roma: Fratelli Bocca, 1955, p.136. 
tradicionais da invenção poética: a poesia passa a ser produzida como desenvolvimento ornamental de ornamentos de base. Tornado “elocução engenhosa" ou "ornato dialético", na base do procedimento encontra-se o conceito, termo de grande polissemia e várias aplicações, muitas vezes equivalentes a agudeza, argúcia, entimema, silogismo retórico, também nomes do efeito de maravilha. ${ }^{135}$

É preciso ressaltar, no entanto, que desde o fim dos anos Quinhentos, muitos poetas e preceptistas questionam essa prevalência do deleite na poesia, como vimos, por exemplo, no tratado de Torelli. O próprio lugar do deleite, ao longo do século XVII, "está longe de acomodação homegênea", como observado por Maria do Socorro Fernandes de Carvalho:

Se nas primeiras décadas do século o princípio bivalente da "utilidade instrutiva e divertimento honesto" como finalidade decorosa do poema serviu para balizar a verossimilhança das obras e o interesse do público, por aderência expressa da preceptiva daqueles momentos, com o passar dos anos, contudo, mais refinada tornou-se a agudeza que matizava os experimentos poéticos. De modo que, em meados do século XVII, aparecem tratados retórico-poéticos que acentuam as distâncias das artes poéticas e das práticas de escrita da poesia dos verossímeis estreitos docere-delectare hiper-regrados, para uma poética de agudeza cujas finalidades pode-se resumir em "proveito e maravilha". ${ }^{136}$

A partir de meados dos anos Seiscentos, "proveito e maravilha" são termos bastante utilizados nas discussões retórico-poéticas sobre as finalidades da poesia e que serão devidamente trabalhados em outros momentos do nosso estudo. Por enquanto, é necessário salientar que embora se empreguem termos diversos, que caracterizam a preceptiva poética seiscentista, docere e delectare ainda norteiam essa poesia, mostrando-se inconsistente a afirmação, propalada desde o século XVIII, ${ }^{137}$ de que não

\footnotetext{
${ }^{135}$ Hansen, J.A. A sátira e o engenho: Gregório de Matos e a Bahia do século XVII, op.cit., p.304.

${ }^{136}$ Carvalho, M. S. F. de. Poesia de Agudeza em Portugal, op.cit., p.277.

137 As críticas feitas por Luís Antônio Verney, especialmente na carta VII do Verdadeiro Método de estudar, e por Cândido Lusitano, em sua Arte Poética, acentuam, entre outras coisas, que a aguda poesia do século XVII seria obscura, inverossímil, afetada, desprovida de juízo e de doutrina, prejudicando-se, assim, a função utilitária que toda poesia deveria ter. Com relação a essas críticas setecentistas, em particular de Verney e de Cândido Lusitano, à produção poética dos anos Seiscentos, vejam-se as considerações de Vítor Manuel Pires de Aguiar e Silva (Maneirismo e Barroco na Poesia Lírica
} 
haveria utilidade, proveito ou doutrina na produção poética dos anos Seiscentos. Por isso, na lírica do século XVII continuam a ecoar as recomendações horacianas de que os poetas, em suas composições, devem procurar unir o deleite à utilidade, "dizendo" coisas belas e proveitosas para a vida: "Aut prodesse uolunt aut delectare poetae / aut simul et iucunda et idonea dicere uitae" (Epistola ad Pisones, vv.333-334). Aqueles que assim fazem, mesclando o útil ao agradável, merecem todos os louvores: "Omne tulit punctum qui miscuit utile dulci, / lectorem delectando pariterque monendo" (Idem, vv.344-343).

Além disso, a poesia lírica seiscentista, visando deleitar e ensinar seus leitores ou ouvintes, imita afetos para mover afetos. ${ }^{138}$ Sobre esse arrebatamento afetivo, podemos lembrar que na retórica aristotélica os afetos são definidos como "as causas que fazem alterar os seres humanos e introduzem mudanças nos seus juízos, na medida em que (...) comportam dor e prazer" (Retórica, II, 1, 1378a); e, ainda de acordo com Aristóteles, o orador deve falar de forma a suscitar o pathos no auditório (Idem, III, 16, 1417a). Tal necessidade de mover os ouvintes, provocando-lhes os afetos fica ainda mais patente no seguinte trecho de Cícero:

sic equidem quom adgredior in ancipiti causa et graui ad animos iudicum pertractandos, omni mente in ea cogitatione curaque uersor, ut odorer quam sagacissime possim quid sentiant, quid existiment, quid expectent, quid uelint, quo deduci oratione facillume posse uideantur. (De Oratore, II, XLIV, 186).

Portanto, como explica Heinrich Lausberg, o mouere é "a influência afectiva, pretendida e exercida pelo orador sobre o árbitro da situação, com a finalidade de nele

Portuguesa, op.cit., pp.146-153), Aníbal Pinto de Castro (Retórica e teorização literária em Portugal, op.cit., pp.383-440) e Ivan Teixeira (Mecenato Pombalino e Poesia Neoclássica. São Paulo: Editora da Universidade de São Paulo, 1999, pp.165-251).

${ }^{138}$ Como afirma D. Antônio de Ataíde, em seu Borrador de uma arte poética que se intentava escrever, "não basta que o poeta cũpra cõ as obrigaçoẽs da arte, se a obra não for pathetica, que he o mesmo que dizer comovedora, de modo que áde mover a algũ afecto, ou a tristeza, ou a alegria ou a semelhante" (fl.39v). Sobre essa "arte poética" de D.Antônio de Ataíde, que se encontra num manuscrito da Biblioteca da Ajuda (46-VIII-37), vale reproduzir aqui as informações de Aníbal Pinto de Castro: "Os apontamentos reunidos neste ms. devem datar dos últimos anos do séc. XVI ou primeiros do seguinte, visto que, na fl.48, há uma nota da mão de qualquer oficial da casa do autor, em que declara ter feito certas entregas de dinheiro em 28-X-1601. D. António de Ataíde foi o $1^{\circ}$ Conde de Castro Daire e $5^{\circ}$ Conde de Castanheira. Nasceu em 1564 e faleceu a 14-XII-1647 (cf. B. Machado, Biblioteca Lusitana, t.I, pp.211-213 e A. Braamcamp Freire, Brasões da Sala de Sintra. $3^{\mathrm{a}} \mathrm{ed}$. Lisboa, Imprensa Nacional - Casa da Moeda, 1974, vol.II, pp.104-105)" (Castro, A. P. de. "Os códigos poéticos em Portugal do Renascimento ao Barroco", op.cit., p.528, nota 90). Veja-se também o texto de Adriano Milho Cordeiro: Registos sobre um Borrador de huma arte poética que se intentava escrever. Torres Novas: Gráfica Almondina, 2008. 
excitar, favoravelmente ao partido, afectos violentos". ${ }^{139}$ Na poesia lírica amorosa do século XVII, movem-se afetos pelo deleite, para instruir acerca das diversas faces de múltiplos e agudos amores, visando ao verdadeiro e perfeito amor, também ele, por ser fruto de agudezas, amor agudo.

Essa finalidade de instruir os leitores ou ouvintes fica evidente quando observamos os constantes ensinamentos sobre o amor nos poemas líricos seiscentistas, como no seguinte romance atribuído a Antônio da Fonseca Soares (Frei Antônio das Chagas) num manuscrito setecentista (na verdade, num dos tomos de uma compilação manuscrita do século XVIII, feita por Antônio Correia Vianna, que reúne grande parte das "obras poéticas" atribuídas a Fonseca Soares), ${ }^{140}$ romance esse que também aparece, mas como composição anônima e com algumas diferenças no texto, em outro manuscrito, ${ }^{141}$ cuja lição preferimos não adotar, embora seja, possivelmente, anterior àquela compilação setecentista:

Amar mucho, y penar poco,

nó lo consiente el Amor;

que de Amor, que todo és fuego,

és materia el coraçon.

Amar, y callar las penas,

nó acredita la paccion;

porque donde ay fuego vivo,

ay luzes, como ay ardor.

Amar, y tener quietud,

implica contradiccion;

que como el Amor tiene alas,

el que más buela, és mejor.

Amar, y nó tener zelos,

yá más Amor lo admitió;

porque prezume de Rey;

\footnotetext{
${ }^{139}$ Lausberg, H. Elementos de Retórica Literária. Tradução, prefácio e aditamentos de R. M. Rosado Fernandes. 5aed. Lisboa: Fundação Calouste Gulbenkian, 2004, p.105.

${ }^{140}$ Obras em que se incluem Romances Liricos Castelhanos de Antonio da Fonseca Soares cujos saõ dos q. meramente vagam manuscritos; deixando-se outros, que com nome de Anonimo, andam impressos nos sinco Tomos da Fenix Renascida. $6^{\circ}$ Tomo das Obras do dito Autor Adquiridas de diversas partes: destribuidas na ordem q̃. aqui se mostram; e escriptas por Antonio Correya Viana. Lisboa, 1777. Lisboa: Biblioteca da Ajuda, Ms. 49-III-79, pp.262-265.

${ }^{141}$ Trata-se do já mencionado manuscrito 130 da Biblioteca Pública de Braga: Jardim Cultivado com varias flores parnasianas nacidas de diversos engenhos, acumulandoas a este volume a curiosidade, para entertenimento do gosto, fls. $133 \mathrm{v}-134$.
} 
y ũn Rey a ũn nó sufre dós.

Amar, y nó se atrever,

és vana prepoziccion;

que como el Amor és ciego,

nó vê la cára ál temôr.

Amar a ũn por ser querido,

és la loucura mayor;

porque como Amor és niño,

nó conosce la razon.

Amar, y ser avariento,

és notoria opoziccion;

que Amor és desnudo, y haze

de la pobreza valor.

Amar, y afectar respectos,

és delicto sin perdon;

porque nó ay dezigoaldades

en el Tribunal de ũn Dios.

Amar, y nó sogetarse,

amor nó és, és furor;

porque tiene el Amor flexas,

y és ũn rayo cada harpõn.

Amar, y nó ser amado,

és desdicha, nó és rigor;

que Amor flexa pomo, y oro,

pero nó tiene eleccion.

Amar, y vivir ausente,

nós és vida, és muerte peôr;

porque muriendo el alivio,

se eterniza la afliccion.

Amar, y ser olvidado,

és la desdicha mayor;

porque ofenden más los bienes

despues de la privaccion.

Amar, y nó pertender,

hipocrezia és de Amor;

que como Amor fué dezeo,

vivió de lo que esperó. 
Amar, y nó sufrir mucho,

és conveniencia, amor nó;

que Amor és tirano, y dá

las penas por galardon.

$\mathrm{Na}$ compilação de Correia Vianna, com base na qual transcrevemos esse romance, o poema é precedido por um título que deixa claro qual é o assunto a ser tratado: "Effectos, y consequencias del Amor". Não discutiremos, ainda, nem os efeitos, nem as consequências e nem a própria noção de amor; no entanto, a leitura desse romance nos mostra que a poesia lírica seiscentista não é apenas deleite, prazer ou maravilha, mas também ensinamento, utilidade ou proveito, ou melhor, é um deleite instrutivo, um prazer útil e uma maravilha proveitosa. A lírica amorosa, em particular, é também uma "arte de amar" que, nos moldes da Ars Amatoria de Ovídio, ensina as "técnicas" do amor. Porém, a aguda arte de amar do século XVII ensina que o amor é múltiplo e complexo: ele pode ser tanto virtude quanto, como se lê na composição acima transcrita, atribuída por Correia Vianna a Antônio da Fonseca Soares, "fuego", “ciego", "niño", "desnudo" e "tirano". Nesse romance, os leitores ou ouvintes são instruídos sobre os efeitos e consequências desse amor-fogo, que não consente que se ame muito e que se sofra pouco, restando aos amantes, como galardão amoroso, somente as penas.

Assim, a poesia seiscentista não tem como única finalidade o deleite ou o prazer, como se sugere, muitas vezes, desde o século XVIII. ${ }^{142}$ Embora muitos autores do século XVII (e, principalmente, aqueles dos séculos posteriores que leem essa poesia) acentuem o delectare, o docere não é excluído, nos anos Seiscentos, das finalidades da poesia. Alguns poetas e comentadores seiscentistas chegam, inclusive, a sujeitar o delectare ao docere, considerando este último o fim principal de todo poema. É o que podemos depreender, por exemplo, de alguns comentários de Manuel de Faria e Sousa: ${ }^{143}$ "Adviertese a los que se dan a escribir versos, (...) que escriban siempre con la mira a enseñar algo de lo util"; 144 "la buena dotrina seca i desnuda es mala de recibir de

\footnotetext{
${ }^{142}$ Ver nota n.134.

${ }^{143}$ João Manuel Tavares da Costa, em sua dissertação de mestrado intitulada A Poética de Manuel de Faria e Sousa, afirma que, para Faria e Sousa, "os ornamentos da poesia têm uma função anciliar e hierarquicamente inferior à doutrina: ensinar é um fim, enquanto deleitar é um meio." (Dissertação de Mestrado em Literaturas Clássicas apresentada à Faculdade de Letras da Universidade de Coimbra. Coimbra: 1996, p.93).

${ }^{144}$ Faria e Sousa, M. de. Fuente de Aganipe. Parte Segunda. Poema de Tamyra i las Musas, Advertencia, $\S 12$. En Madrid, por Iuan Sanchez, 1644.
} 
los umanos, conviene para ser admitida, disfraçarla con cosas apetecidas dellos"; ${ }^{145}$ "i como los grandes hombres no escriben sino para enseñar, i la enseñança es dificil de admitir, bañanla con dulçuras, para que acudiendo a ellas algunos vengan a caer en ella". ${ }^{146}$

Portanto, no século XVII, a poesia lírica, enquanto gênero poético, imita e move afetos, deleitando e ensinando os leitores ou ouvintes. Entre as matérias apropriadas ao gênero lírico, está o amor; e a lírica amorosa não só deleita ao tratar, com "doçuras", de assuntos amorosos, mas também ensina a arte de amar. O que é ensinado faz parte da invenção da poesia e do próximo capítulo do nosso trabalho. No entanto, podemos adiantar que o amor agudo, fruto dessa aguda poesia seiscentista, é imitação de amores vários; abarcando diversas fontes filosóficas e poéticas, ele torna ainda mais florido e frutífero esse jardim de imitações líricas e versos agudos que, reunidos pelos laços de tal amor, formam exuberantes ramalhetes amorosos.

É preciso, enfim, retomar aquilo que afirmamos no começo: se o genêro integra a matéria, a discussão sobre o amor agudo nos levará a uma melhor compreensão do gênero lírico, em particular, da lírica amorosa. Desse modo, não pretendemos definir tal poesia neste capítulo inicial do trabalho, mas apenas delimitar o campo em que se cultiva o amor agudo. Trata-se, aliás, de um campo extremamente vasto, com uma grande variedade de matérias férteis; variedade essa que, desde Horácio, foi cada vez mais acentuada, como se pode notar no seguinte trecho de Escalígero:

Lyricorum materiam plane demonstrauit Horatius. Mihi ita videtur. Quæcunque in breue Poema cadere possunt, ea Lyricis numeris colligere ius esse. Laudes, amores, iurgia, infectationes, comessatoria, obiurgatoria, vota, ad indulgendũ genio exhortationes. Cõtra, Sobrietatis cõmendationes. Gestorũ summarias explicationes, desideria, conquestiones, locorũ, tẽporum explicationes, noua cõsilia, deliberationes, negotiorũ susceptiones, susceptorũ repudiationes, inuitationes, repulsiones, dehortationes, detestationes, $\&$ alia siqua sunt. Amat autem poema hoc animi libertatẽ... ${ }^{147}$

\footnotetext{
${ }^{145}$ Lusiadas de Luis de Camoens comentadas por Manuel de Faria i Sousa. Tomo Primero. Prologo, col. 10. En Madrid, por Iuan Sanchez, 1639.

146 Idem ibidem.

${ }^{147}$ Escalígero, J. C. Poetices Libri Septem (1561). Livro III, cap.124.
} 
Essa "liberdade" da lírica é também assinalada na definição de Francisco Cascales, em suas Tablas Poeticas: "Imitacion de qualquier cosa que se posponga: pero principalmẽte de alabanças de Dios, y los Santos, y de banquetes, y plazeres, reduzidas a un concepto Lyrico florido", 148

O amor é somente uma das diversas matérias adequadas a essa variedade temática dos poemas líricos. Todavia, a concepção do amor agudo é determinante, especificamente, para a lírica amorosa seiscentista. Por isso, à medida que nos aprofundarmos naquela concepção, será mais bem caracterizada esta poesia, cujas raízes de seu estilo florido e ornado, ${ }^{149}$ embebidas nas fontes de seu amor agudo, serão estudadas neste próximo capítulo.

${ }^{148}$ Cascales, F. Tablas Poeticas. Murcia: por Luis Beros, 1617, pp.403-404.

149 "Lo stile del lirico poi, se bene non così magnifico como l'eroico, molto più deve essere fiorito ed ornato: la qual forma di dire fiorita (come i retorici affermano) è propria della mediocrità. Fiorito deve essere lo stilo del lirico: e perché più spesso appare la persona del poeta, e perché le materie che si pigliano a trattare per lo più sono, le quali, inornate di fiori e di scherzi, vili ed abiette si rimarrebbono: onde se per aventura fosse la materia morata trattata con sentenze, sarà di minor ornamento contenta." (Tasso, T. Discorsi dell'Arte Poetica e in particolare sopra il Poema Eroico. In: Prose. A cura di Ettore Mazzali. Milano, Napoli: Riccardo Ricciardi, 1959, p.395). 


\section{Capítulo 2}

\section{De cultas flores e fontes várias se compõe o amor agudo}

Na composição do gênero lírico, é também determinante a adequação do estilo, pois, como afirma Maria do Socorro Fernandes de Carvalho, "ao fim, é o estilo o que se imita". ${ }^{150}$ Para imitá-lo, é preciso, entre outras coisas, atender à conveniência entre estilo e matéria. ${ }^{151}$ Portanto, na concepção de amor agudo, está implicada a apropriação do estilo: retomando-se os tria genera da Rhetorica ad Herennium, à lírica é comumente associado o "gênero mediano" (mediocris):

Sunt igitur tria genera, quae genera nos figuras appellamus, in quibus omnis oratio non uitiosa consumitur: unam grauem, alteram mediocrem, tertiam extenuatam uocamus. Grauis est, quae constat ex uerborum grauium leui et ornata constructione. Mediocris est, quae constat ex humiliore neque tamen ex infima et peruulgatissima uerborum dignitate. Attenuata est, quae demissa est usque ad usitatissimam puri consuetudinem sermonis. (Rhetorica ad Herennium, IV, 11). ${ }^{152}$

Quintiliano, embora empregue outros termos, faz uma divisão dos genera dicendi semelhante a essa da Rhetorica ad Herennium: "Namque unum subtile, quod ischnon uocant, alterum grande atque robustum, quod hadron dicunt, constituunt, tertium alii medium ex duobus, alii floridum (namque id antheron appellant)

\footnotetext{
${ }^{150}$ Carvalho, M. S. F. de. Poesia de Agudeza em Portugal, op.cit., p.172.

151 "Le choix d'un style oblige à suivre un ensemble de contraintes définies par les qualités de 1 'expression, pureté (latinitas), clarté (perspicuitas) et ornement (ornatus). La quatrième des qualités distinguées par les théoriciens, la propieté (aptum, quod decet) est précisément celle qui justifie l'unité de chaque style et le rapport qu'il entretient avec la matière." (Molino, J. "Qu'est-ce que le style au XVII ${ }^{\mathrm{e}}$ siècle?". In: Critique et Création Littéraires en France au XVII 'Siècle. Paris: Éditions du Centre National de la Recherche Scientifique, 1977, p.344).

152 "Há três gêneros, que denominamos figuras, aos quais todo discurso não vicioso se reduz: um chamado grave, outro médio e o terceiro tênue. O grave é composto de palavras graves em construção leve e ornada. O médio constitui-se de uma categoria de palavras mais humilde, todavia não absolutamente baixa e comum. O atenuado desce ao costume mais usual da simples conversa." (Retórica a Herênio. Tradução e introdução Ana Paula Celestino Faria e Adriana Seabra. São Paulo: Hedra, 2005, p.213).
} 
addiderunt" (Inst. Orat., XII, 10, 58). ${ }^{153} \mathrm{O}$ primeiro gênero dessa divisão, o sutil, tem o ofício de ensinar (docere); o segundo, denominado "grande e robusto", o de mover (mouere); e o terceiro, "médio" ou "florido", o de deleitar (delectare). Como é a este último que o estilo lírico - também dito, muitas vezes, "florido" - está normalmente vinculado, vale destacar que Quintiliano define tal "modo médio" (medius modus) como aquele em que há uma maior abundância de metáforas e que é mais agradável devido ao uso de figuras; "ameno, pelas digressões; conveniente, pela composição; doce nas sentenças, brando como um rio e verdadeiramente translúcido, mas ensombrado pelo arvoredo nas margens que verdejam de ambos os lados". 154

É preciso ressaltar, no entanto, que "o gênero lírico tira proveito da ornamentação muito elevada e abundante dos gêneros altos, mas também da simplicidade e correção dos baixos". ${ }^{155}$ Assim, a noção de estilo decorre, em princípio, desses genera dicendi das retóricas antigas, sendo que o emprego do termo stylus se torna frequente apenas nos séculos XII e XIII, quando esses três genera antigos, que passam então a ser chamados de estilos, são relacionados com as três obras de Virgílio (a dita Rota Vergilii): ao baixo correspondem as Bucólicas; ao médio, as Geórgicas; e ao grave, a Eneida. ${ }^{156}$ Enfim, como sintetiza Heinrich Lausberg:

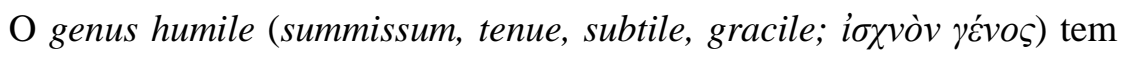
pouco ornatus, porque só quer ensinar (docere) e provar (probare). As suas virtudes são, portanto, a puritas e a perspicuitas. Corresponde na prosa, p.ex., ao estilo epistolar e ao estilo de César, e na poesia, (...) ao estilo das éclogas de Virgílio.

O genus medium (modicum, mediocre, moderatum, floridum; $\mu$ ćбov,

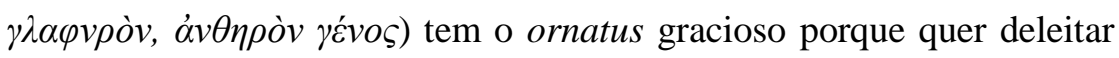
(delectare). (...) O grau de afecto correspondente é o ethos. O genus

\footnotetext{
153 "Com efeito, um é o sutil, que chamam iskhnós; outro, o grandioso e robusto, que dizem hadrós; o terceiro, uns o estabelecem no meio dos dois, outros o deram como florido (pois o nomeiam antherós)". ("Dos gêneros de discurso - Quintiliano. Instituição oratória. 'Livro XII', 10, 58-80". Tradução de Thaís Morgato Martin. In: Letras Clássicas, n.9, 2005, p.226).

${ }^{154}$ Idem, ibidem. "Medius hic modus et tralationibus crebrior et figuris erit iucundior, egressionibus amoenus, compositione aptus, sententiis dulcis, lenior tamquam amnis et lucidus quidem sed virentibus utrimque ripis inumbratus." (Inst. Orat., XII, 10, 60).

${ }^{155}$ Carvalho, M. S. F. de. Poesia de Agudeza em Portugal, op.cit., p.206.

156 "Dans les arts poétiques du XII e et du XIII ${ }^{\text {e }}$ siècles, les styles - pour lesquels le terme «stylus» est fréquemment employé pour la première fois en lieu et place de l'expression «genus dicendi» - les trois styles simple, médiocre et sublime sont mis en relation avec les trois œuvres de Virgile, Bucoliques, Géorgiques et Enéide, qui fournissent des modèles pour trois grands types de création littéraire distingués par la dignité de leurs personnages" (Molino, J. "Qu'est-ce que le style au XVII siècle?", op.cit., pp.343344).
} 
corresponde, dentro da poesia, p.ex., ao estilo da lírica descritiva, e na Idade-Média, é atribuído às Geórgicas de Virgílio (...).

O genus sublime (grande, robustum, vehemens, amplum, grandiloquum, validum; $\dot{\alpha} \delta \rho o ̀ v ~ \gamma \varepsilon ́ v o \varsigma)$ tem o ornatus patético, porque quer comover (movere). (...) Dentro da poesia, corresponde este genus, p.ex., à tragédia e é atribuído à Eneida de Virgílio. ${ }^{157}$

Porém, no século XVII, a noção de estilo não se restringe a esses três genera retóricos, os quais eram diversificados já entre os antigos, como se observa em Quintiliano. ${ }^{158}$ Trata-se, assim, de uma concepção complexa que, constituída por diversas fontes, é caracterizada pela variedade de estilos, como assinala Jean Molino:

Les œuvres humaines, les discours comme les hommes, sont infiniment variés. Les variétés du style reflètent donc la variété de l'espèce humaine et en retrouvent les divers axes de variation: le style dépend des qualités de l'âme (imagination, mémoire et esprit), de la diversité des inclinations et des tempéraments du corps, des pays et de leur climat, de l'époque, de la matière enfin que l'on traite. ${ }^{159}$

Desse modo, devemos buscar nos tratados seiscentistas discussões que nos permitam compreender melhor a noção de estilo na preceptiva retórico-poética do século XVII. Entretanto, antes de analisarmos os tratados, é válido destacar a possível origem do termo propalada na época, como se lê no Vocabulário de Bluteau: "Antes da invençaõ do papel escreviaõ os antigos em laminas de chumbo, em taboas engessadas,

\footnotetext{
${ }^{157}$ Lausberg, H. Elementos de Retórica Literária, op.cit., pp.271-272.

158 "Sed neque his tribus quasi formis inclusa eloquentia est. Nam ut inter gracile validumque tertium aliquid constitutum est, ita horum intervalla sunt atque inter haec ipsa mixtum quiddam ex duobus medium est, quoniam et subtili plenius aliquid atque subtilius et vehementi remissius atque vehementius invenitur, ut illud lene aut ascendit ad fortiora aut ad tenuiora summittitur. Ac sic prope innumerabiles species reperiuntur, quae utique aliquo momento inter se differant: sicut quattuor ventos generaliter a totidem mundi cardinibus accepimus flare, cum interim plurimi medii et eorum varia nomina et quidam etiam regionum ac fluminum proprii deprehenduntur." (Inst. Orat., XII, 10, 66-67). "Mas a eloqüência não está encerrada nessas três - digamos - formas. Pois assim como entre o gracioso e o vigoroso se estabeleceu um terceiro, assim também existem intervalos desses, e entre esses mesmos [intervalos] existe certo intermediário, misturado dos dois, já que tanto se encontra algo mais pleno e mais sutil que o sutil, quanto [algo] mais remisso e mais veemente que o veemente, assim como o brando ou ascende até o mais forte ou se submete ao mais tênue. $\mathrm{E}$ assim se descobrem espécies quase inumeráveis, que, de qualquer modo, diferem entre si por alguma circunstância; assim como aceitamos que, de modo geral, quatro ventos sopram de outros tantos pontos cardeais do mundo, quando todavia se compreendem muito mais intermediários, e variados nomes deles, e alguns ainda próprios de regiões e também de rios." (Tradução de Thaís Morgato Martin, op.cit., p.227).

${ }^{159}$ Molino, J. “Qu'est-ce que le style au XVII' siècle?”, op.cit., p.350.
} 
ou cubertas de cera, com hũ ponteiro, ou penna de ferro, a que chamavaõ Stylus, donde procedeo, que a phrase, \& o modo de compor, tambem foi chamado Estilo." Nota-se, então, que esse instrumento pontiagudo, normalmente composto de ferro e usado para escrever em tábuas cobertas de gesso ou de cera, era chamado pelos antigos de stylus, termo que, posteriormente, passou a significar "modo de escrever, cõpor, ou fallar qualquer lingoa”. Mais ainda: o mesmo Bluteau, citando Cícero e Plínio, afirma que é possível "seguir, ou imitar o estilo de alguem" ou "imitar o estilo dos antigos Authores", ficando evidente, dessa maneira, que os diferentes estilos não se resumem aos três genera dicendi das retóricas antigas, mas variam conforme o diverso modo de escrever, compor ou falar de cada auctoritas. ${ }^{160}$

Essa variedade de estilos é também afirmada por Gracián, cujo discurso LXI de sua Agudeza y Arte de Ingenio é denominado, justamente, "De la Variedad de los Estilos". No entanto, é no discurso LX ("De la Perfeccion del Estilo en comun") que a questão começa a ser discutida: "Dos cosas hazen perfecto vn estilo, lo material de las palabras, y lo formal de los pensamientos, que de ambas eminẽcias se adequa su perfeccion". ${ }^{161}$ Sem esclarecer em que consiste o "material das palavras" e o "formal dos pensamentos", que tornam o estilo perfeito, Gracián acrescenta que "son los Conceptos vida del estilo, espiritu del dezir". ${ }^{162}$ E é preceito fundamental a adequação ("la decencia") das palavras, pensamentos e conceitos aos diferentes discursos, poemas ou cartas: "Pide muy diferentes pensamientos, y aun palabras vna Carta familiar, que vna Oracion; ni merece ser assunto principal de vn Sermon el Concepto, que es brillante para vn Soneto". ${ }^{163}$ Os romances, por exemplo, requerem conceitos galantes, enquanto os sonetos, se forem heroicos, conceitos majestosos, se críticos, picantes, se burlescos, donosos, se morais, sentenciosos e graves.

Sendo o conceito "vida do estilo", é importante examinar essa noção, muito debatida na produção retórico-poética seiscentista. Segundo Gracián, na sua já citada definição, o conceito "es vn acto del entendimiento, que exprime la correspondencia, que se halla entre los objectos"; ${ }^{164}$ e são diversas as espécies de conceitos: por correspondência e proporção, por dessemelhança, por disparidade, por ficção etc.

\footnotetext{
${ }^{160}$ Bluteau, R. Vocabulario Portuguez, \& Latino, op.cit., volume 3, verb. “estilo”, pp.319-320.

${ }^{161}$ Gracián, B. Agudeza y Arte de Ingenio, op.cit., p.364.

${ }^{162}$ Idem, p.365.

${ }^{163}$ Idem, p.366.

${ }^{164}$ Idem, p.7.
} 
Para compreender melhor essa definição de Gracián, vale recordar o que ensina uma das principais fontes antigas sobre o tema. Assim, lemos no De Anima de Aristóteles que "para a alma capaz de pensar, as imagens subsistem como sensações percebidas. E, quando se afirma algo bom ou nega-se algo ruim, evita-o ou persegue-o. Por isso, a alma jamais pensa sem imagem" (III, 7, 431a8). Nesse sentido, conclui Aristóteles: "Em suma, o intelecto em ato é os seus objetos" (III, 7, 431b12). ${ }^{165}$ Portanto, no De Anima, qualquer discurso é considerado metafórico por natureza, "pois os noeta, os conceitos, são imagens mentais que substituem os aistheta, os objetos da percepção. Os signos verbais, orais e escritos, são entendidos como imagens das imagens mentais"; 166 e quando Gracián e outros autores quinhentistas e seiscentistas discutem os "conceitos", retomam, especialmente, os noeta aristotélicos.

Em fins do século XVI, Torquato Tasso, por exemplo, afirma que os conceitos (concetti) são imagens das coisas: "le quali imagini non hanno soda e reale consistenza in se stesse come le cose, ma nell'animo nostro hanno un certo loro essere imperfetto; e quivi da l'imaginazione sono formate e figurate". ${ }^{167}$ Já as palavras (parole) são imagens dos conceitos, os quais estão no nosso "ânimo", e os conceitos são imagens das coisas que estão fora do intelecto: por isso, as palavras são imagens das imagens. Enfim, "possiamo dunque concludere che le parole seguono i concetti, e '1 verso parimente". 168

A definição de Pinciano, na sexta epístola de sua Philosophía Antigua Poética, é bastante semelhante a essa de Tasso e recorre, igualmente, a Aristóteles: "Concepto se dice una imagen que de la cosa el entendimiento forma dentro de sí”. ${ }^{169}$ Para Pinciano, há três espécies de conceitos: graves, agudos e circunflexos ou medianos. "Concepto grave se dice de la noticia que el hombre de la cosa concibe, cuando es magnífica y alta; (...) el concepto grave es aquel que el entendimiento forma de la cosa, mayor que ella es; y el agudo, el que le forma muchas veces menor, pero más sutil y delicado". ${ }^{170}$ Quanto aos conceitos circunflexos ou medianos, o autor se restringe a mencionar que não são nem graves nem agudos e que são feitos de uns e de outros. Desse modo, os poetas devem observar a adequação entre essas diferentes espécies de conceitos e os

\footnotetext{
${ }^{165}$ De Anima. Apresentação, tradução e notas de Maria Cecília Gomes dos Reis. São Paulo: Editora 34, 2006.

${ }^{166}$ Hansen, J. A. "Retórica da agudeza". In: Letras Clássicas, n.4, 2000, p.319.

${ }^{167}$ Discorsi dell'arte poetica (1587). In: Prose. Milano: Rizzoli, 1935, pp.395-396.

${ }^{168}$ Discorsi del Poema Eroico (1594). In: Prose. Milano: Rizzoli, 1935, p.504. Como sabemos, esses Discursos são uma versão ampliada dos Discorsi dell'arte poetica e in particolare sopra il poema eroico (Veneza, 1587).

${ }^{169}$ Pinciano, A. L. Philosophía Antigua Poética, op.cit., p.275.

${ }^{170}$ Idem, p.276.
} 
gêneros em que compõem: "Siga, pues conviene, cada poeta su advocación y ni el trágico ni el épico tengan conceptos muy agudos; ni el cómico, o lírico, o epigramático, graves; sino que, así como en las palabras, sea en los conceptos imitador de todo género de persona". ${ }^{171}$

Seguindo de perto Pinciano, Manuel Pires de Almeida considera que há três gêneros de estilos: "Um grandíloco, que é dos príncipes e heróis; medíocre e meão, que é dos nobres; ínfimo, que é da plebe". ${ }^{172}$ Além disso, ressalta que o estilo adequado à épica (assunto principal desse seu Discurso sobre o Poema Heróico) é o grandíloco, já que essa poesia é imitação dos melhores e dos heróis; e esse estilo, apropriado ao poema heróico, "ou se faz grande por razão dos tropos e figuras, ou das palavras, ou dos conceitos". ${ }^{173}$ Portanto, de acordo com Pires de Almeida, o conceito é elemento essencial do estilo, correspondendo àqueles três gêneros de estilos três espécies de conceitos: graves, agudos e circunflexos. As definições dessas espécies apresentadas pelo preceptista português reproduzem aquelas de Pinciano, também não sendo definido, explicitamente, o conceito circunflexo: "Conceito grave se diz a notícia que o homem concebe da coisa que é magnífica e alta, ou aquele que o entendimento forma da coisa maior que ela é (...). O conceito agudo é o que forma o entendimento muitas vezes menos da coisa que é, porém mais sutil e delicado". ${ }^{174}$ Desse modo, o conceito grave faz o estilo grande e adequado à épica. Já o conceito agudo não é conveniente à epopeia, pois a linguagem do poema heroico deve ser "peregrina" e, com o uso de conceitos agudos, se fariam enigmas, tornando essa linguagem nada inteligível; além disso, "a épica é imitação de príncipes, e estes falam com mais gravidade e simplicidade alta e pura que a gente menor, a quem a necessidade, grande mestra de agudezas, faz sutil, e aguda". 175

Uma discussão mais detalhada sobre a noção de conceito é apresentada por Francisco Leitão Ferreira, na sua Nova Arte de Conceitos. Sua definição, embora mais elaborada, está em consonância com aquelas que citamos anteriormente:

Nenhuma outra cousa he (...) o conceyto mais, que o pensamento, idea, ou imagem, que o entendimento forma em si mesmo de algũa cousa: \&

\footnotetext{
${ }^{171}$ Idem, p. 277.

${ }^{172}$ Discurso sobre o Poema Heróico, fl.633v. Citamos o texto com base na já mencionada edição de Adma Muhana.

${ }^{173}$ Idem, ibidem.

${ }^{174}$ Idem, fl.634v.

${ }^{175}$ Idem, fls.634v-635.
} 
formar conceyto de alguma cousa he o proprio, que representalla no entendimento, conhecendo-a, ou como ella em si he, ou parece, ou se imagina ser.

Por isto a este vocabulo Conceyto chamàraõ os Gregos em seu idioma Ennîa, ou Idea; os Latinos, Noçaõ, ou Exemplar, \& as demais nações vulgarmente, Intençaõ, Modello, ou Imagem, que representa, debuxa, \& pinta no entendimento a semelhança, idolo, \& simulacro de qualquer objecto, ou verdadeyro, como v.c Leã̃; ou verisimil, como Bucéfalo; ou fantastico, como Quimera; ou fabuloso, como Esfinge. ${ }^{176}$

Assim, para Leitão Ferreira, o conceito é uma imagem de uma coisa que o entendimento forma dentro de si; porém, acrescenta que para se "formar conceito" de alguma coisa, ou seja, para representá-la no entendimento, é necessário conhecê-la, não importando se ela é verdadeira, verossímil, fantástica ou fabulosa. Portanto, os conceitos pressupõem o conhecimento dos objetos representados no entendimento; e as diferentes qualidades desses objetos (“ilustres, médios e inferiores”) é que determinam as mesmas qualidades dos conceitos: "conceyto illustre serà o que tem por objecto ao Anjo: medio, o que si affigura ao homem: infimo, o que só representa ao bruto". ${ }^{177}$ Havendo essa convergência entre conceito e objeto, o que se forma é um conceito perfeito: "he o que se proporciona todo, \& em tudo com o seu objecto"; sem tal convergência, tem-se um conceito monstruoso: "he o que por diminuto, ou por excessivo, se naõ iguala com o seu objecto". ${ }^{178}$

Nas lições XXII e XXIII de seu tratado, Leitão Ferreira expõe e define diversos conceitos (ele não deixa claro se são "espécies"), tais como "verdadeiro", "falso", "afetado", "quimérico", "natural”, "verossímil”, "paradoxo" e "hiperbólico". Todavia, neste momento, interessa-nos destacar um outro conceito, o "verbal engenhoso", pois é, segundo o autor, "a parte mais nobre da locução humana". Além disso, esse conceito é de grande importância para se discutir a aguda poesia seiscentista. Define-o, então, o preceptista português: "He o conceyto verbal engenhoso, hũa Imagem sensivel do entendimento reflexo, representada em palavras metaforicas de figuraçaõ peregrina". ${ }^{179}$ Enquanto conceito, é este também uma imagem - no caso, sensível, já que pode ser ouvida ou vista; sua peculiaridade, no entanto, está na sua representação: as palavras

\footnotetext{
${ }^{176}$ Nova Arte de Conceitos. Primeira parte, op.cit., pp.12-13.

${ }^{177}$ Idem, p.14.

${ }^{178}$ Idem, pp.14-15.

${ }^{179}$ Idem, p.95.
} 
metafóricas de figuração peregrina é que caracterizam esse conceito como engenhoso. $O$ próprio Leitão Ferreira esclarece em que consiste tal especificidade, ao diferenciar o conceito verbal engenhoso do verbal simples: enquanto o segundo "representa o objecto por meyo de vocabulos naturaes, \& proprios", o primeiro representa o objeto, ou melhor, "significa-o, mediante as vozes metaforicas, que na definiçaõ chamamos peregrinas, naõ porque sejaõ estrangeyras, mas porque saõ alheas, \& improprias da cousa a que se transferem". ${ }^{180}$ É engenhoso, por exemplo, não o conceito que se funda na imagem simples, comum e própria do vocábulo "espada", isto é, um objeto cortante e pontiagudo, feito de ferro, que tem como ofício ferir com golpes e trespassar com furos; e sim aquele conceito em que o objeto "espada" é representado pela palavra imprópria "relâmpago", formando-se, assim, uma "engenhosa metafora para significar a espada nua na mão de hum heroe guerreyro, vibrada com denodado impulso". ${ }^{181}$ Desse modo, o conceito engenhoso funda-se na metáfora, pois no uso desta, segundo a concepção aristotélica citada por Leitão Ferreira, são necessárias duas coisas em que se baseiam aquele conceito: a conveniência, "decência" ou decoro (decenter) entre os "translatos", de forma que as "translações" não sejam remotas ou afetadas, nem humildes ou comuns; e a prontidão, destreza ou agilidade (versatilis) do engenho, para trocar, separar, unir e investigar as "apreensões" dos objetos. Concluindo tal questão, Leitão Ferreira descreve o procedimento para se deduzir de um assunto um conceito engenhoso ou uma metáfora; descrição essa que também esclarece importantes fundamentos das agudezas seiscentistas:

Propoem-sevos hum assunpto, quereis deduzir delle algum conceyto, mas logo encontrais algum obstaculo no discurso, ou seja pela esterilidade do thema, ou pelo embaraço das noções, que talvez suffocaõ a fantasia, \& confundem a apprehensaõ: eis-que entra o engenho a fazer o seu officio, \& com a promptidaõ natural da ligeyreza, começa a confrontar as circunstancias, ajunta-as, ou divide-as, ou diminue-as; troca hum objecto por outro, esta por aquella especie; \& desta veloz agitaçaõ ajudado o juizo, forma proposições metaforicas, de que depois o discurso tira demonstrações verisimeis, ou conclusoẽs verdadeyras; \& deste modo, naõ só achais a metafora, mas deduzìs o

\footnotetext{
${ }^{180}$ Idem, pp.95-96.

${ }^{181}$ Idem, p. 98.
} 
conceyto; \& fertilizais o assumpto, manifestando com imagẽs da locuçaõ sensivel, quanto intrinsecamente fabricastes com o engenho. ${ }^{182}$

Para retomarmos a definição de conceito de Gracián e sua discussão sobre o estilo, vale ressaltar que Leitão Ferreira questiona (no §.III da quinta lição de seu tratado, intitulado "Impugna-se a definiçaõ, que Lourenço Gracian dà ao conceyto") a opinião do autor espanhol sobre o tema. Este último, como já vimos, define o conceito como "um ato do entendimento que exprime a correspondência que se acha entre os objetos"; Gracián funda essa noção, como bem salienta o preceptista português, naquela, que também já citamos, de agudeza: “Consiste, pois, este artifício conceituoso em uma primorosa concordância, em uma harmônica correlação entre dois ou três cognoscíveis extremos, expressada por um ato do entendimento". Leitão Ferreira não concorda com essa definição de conceito, pois nela se define apenas o "conceito formal" ou "imagem insensível", isto é, o ato do entendimento que representa e exprime a correspondência ou harmonia entre os objetos correlatos; falta, portanto, algo essencial, conforme a concepção do preceptista português: a imagem sensível engenhosa que, por meio dos vocábulos, propõe, representa e exprime os atos do entendimento, consistindo o conceito verbal engenhoso não naquela imagem insensível, mas nesta que se faz sensível a outro entendimento. Enfim, como elucida o próprio autor:

Aquella expressaõ de correspondencia, representada no acto intellectivo, he imagem, que o entendimento fórma das especies intelligiveis dos objectos, proporcionando humas com outras; mas esta imagem, como já dissemos, he insensivel, \& naõ negamos que seja engenhosa, mas necessita de nova imagem, que a faça sensivel a outro entendimento, a qual he o conceyto verbal engenhoso, fundado em algũa metafora. ${ }^{183}$

Assim, Leitão Ferreira destaca, indiretamente, algo importante na concepção de concepto de Gracián: ela depende da noção de agudeza, central no tratado do autor espanhol; por isso, o que é peculiar na sua definição de conceito é a menção à correspondência ou concordância entre objetos diversos. Essa peculiaridade está de acordo com a preceptiva seiscentista sobre a agudeza. Matteo Peregrini, por exemplo,

\footnotetext{
${ }^{182}$ Idem, pp.123-124.

${ }^{183}$ Idem, pp.102-103.
} 
ao discutir a essenza dell'acutezza, no capítulo III de seu tratado Delle Acutezze, ${ }^{184}$ afirma que a natureza das agudezas maravilhosas (mirabili) ${ }^{185}$ "in un detto non è altro che parole, obbietti significati e loro vicendevole collegamento. Le parole, sì come anche gli obbietti o cose appartatamente considerate, sono pura materia: dunque l'acutezza si regge necessariamente dal legamento". ${ }^{186}$ Esse legamento pode dar-se entre palavras e palavras, entre coisas e palavras e entre coisas e coisas, sendo tal liame artificioso ou sem artifício. Quando se trata da agudeza, não interessa a discussão do legamento natural, casual ou sem artifício, mas apenas do artificioso, "perché l'acutezza per cosa artificiosa si è presupposta". ${ }^{187}$ E o artifício, enquanto fonte do "maravilhoso" (mirabile), não deve ser comum, e sim extremamente raro. Além disso, uma vez que o artifício deve formar objeto visível (obbietto di vista) e bastante deleitável ao ânimo, a sua raridade e virtude se tornarão evidentes ao mostrar a recíproca concordância (acconcezza) entre as partes ligadas, artificiosamente, no "dito" (detto). Isso porque, como explica Peregrini,

tutte le cose che, composte di molte parti, hanno da far oggetto molto dilettevole, vengono a farlo principalmente mediante un molto acconcio riscontro delle medisime parti loro. L'esperienza il dimostra nella musica. E la bellezza corporea, oggetto tanto dilettoso, per concorde senso de' savi si regge principalmente da una rarità di proporzione. Dunque nell'artificioso legamento, sia di cose o parole, che qui viene a considerarsi, il pregio tutto dipenderà dalla vicendevole loro acconcezza. ${ }^{188}$

Portanto, o "artificioso ligamento", que rege a acutezza, depende da concordância entre as partes ligadas. Como salienta Antônio José Saraiva, essa acconcezza, elemento fundamental da preceptiva de Peregrini, designa aquela mesma noção de concordancia, consonancia, correspondencia, que liga artificiosamente os dois extremos, presente nas definições de Gracián de concepto e agudeza; concordam

\footnotetext{
${ }^{184}$ Peregrini, M. Delle Acutezze. Teste e note a cura di Erminia Ardissino. Torino: Edizioni Res, 1997. (Alethes, Collezione di Retorica, n.4).

${ }^{185}$ No capítulo II de seu tratado, Peregrini ressalta que será a acutezza mirabile o objeto principal de seu "discurso", definindo-a da seguinte maneira: "Acutezza mirabile è un detto che, per la virtù dell'ingegno nell'artificio d'esso maravigliosamente campeggiante, riesce molto plausibilmente dilettevole" (Idem, p.29).

${ }^{186}$ Idem, p.30.

${ }^{187}$ Idem, ibidem.

${ }^{188}$ Idem, ibidem.
} 
também ambos os preceptistas ao considerarem que "esta relação entre partes diferentes é de natureza igual àquela em que se baseiam a música e a beleza corporal". ${ }^{189}$ Desse modo, é possível dizer que o concepto concebido por Gracián é "agudo", porque é, ao mesmo tempo, fundamento e consequência da agudeza seiscentista.

Tendo em vista essa discussão, é pertinente retomar aquela afirmação de Gracián de que o conceito é "vida do estilo". Para compreender melhor isso que assevera o jesuíta espanhol, pode-se recorrer à noção de estilo que se depreende dos Discorsi dell'Arte Poetica de Tasso; para este autor, como sintetiza Maria do Socorro Fernandes de Carvalho, o estilo é a "soma dos conceitos mais a elocução". ${ }^{190}$ Assim, mostram-se mais evidentes aquelas duas coisas que Gracián considera necessárias para tornar perfecto o estilo e que, como já mencionado, não parecem devidamente esclarecidas: o "material das palavras" e o "formal dos pensamentos". Respeitando-se as especificidades da obra de Gracián e da preceptiva retórico-poética seiscentista, a referida noção de Tasso nos permite associar o formal dos pensamentos com os conceitos e o material das palavras com a elocução. Isso se confirma no próprio texto do jesuíta espanhol, pois no mesmo discurso LX de sua Agudeza y Arte de Ingenio, depois de serem citados aqueles elementos do "estilo perfeito", são discutidos, justamente, os conceitos e o "verbo", podendo-se inferir que é deles que se compõe o estilo. Se o conceito é vida do estilo, o verbo é seu "nervo":

el nervio del Estilo cõsiste en la intensa profundidad del Verbo. Aylos significativos, llenos de alma, que exprimen con doblada enfasi, y la façonada eleccion dellos, haze perfecto el dezir. (...) Preñado ha de ser el Verbo, no inchado, que signifique, no que resuene, Verbos con fondo, donde se engolfe la atencion donde tenga en que zevarse la comprension. Haze animado el Verbo la traslaciõ, que cuesta, la Alusion, Crysi, Ponderacion, y otras semejantes perfecciones, que con aumento de sutileza fecundan, y redoblan la significacion. ${ }^{191}$

Além disso, recorrendo-se ainda aos Discorsi dell'Arte Poetica de Tasso, é possível afirmar que, também para Gracián, “a variedade de estilos nasce da variedade

\footnotetext{
${ }^{189}$ Saraiva, A. J. O discurso engenhoso. São Paulo: Perspectiva, 1980, p.129.

${ }^{190}$ Carvalho, M. S. F. de. Poesia de Agudeza em Portugal, op.cit., p.211.

${ }^{191}$ Gracián, B. Agudeza y Arte de Ingenio, op.cit., p.369.
} 
de conceitos sobre a coisa". ${ }^{192}$ Ou seja, variam-se os estilos de acordo com as diferentes imagens que o entendimento forma em si sobre a coisa, dependendo sempre o estilo dos conceitos que o constituem.

Todavia, essa variedade de estilos decorre não só dos conceitos, mas também das diversas auctoritates imitadas, como se confirma no discurso LXI da Agudeza y Arte de Ingenio que, como já adiantamos, é dedicado à discussão desse assunto. Segundo Gracián, tal hermosa ${ }^{193}$ variedade se compõe, em princípio, de dois estilos capitais: redundante ou conciso, conforme sua essência; asiático ou lacônico, conforme a autoridade. Seja qual for o estilo, há de ter sempre alma conceituosa: "Vno, y otro estilo han de tener alma conceptuosa, participando del Ingenio su imortalidad". ${ }^{194}$ A partir dessa divisão inicial, no entanto, são comentadas as qualidades específicas, dignas de imitação, de algumas autoridades. Se bem imitados, esses modelos serão fontes de agudezas, pois "no ay Autor de los celebres, y Principes, ̃̃ no tenga alguna especial eminencia de Agudeza". ${ }^{195}$ Dessa maneira, a variedade dos estilos não parece se resumir àqueles dois mencionados, mas se mostra tão ampla e diversa quanto as autoridades passíveis de imitações. Enfim, depois discorrer sobre as principais qualidades de autores antigos e modernos, conclui Gracián: "O tu qualquiera que aspiras a la imortalidad, con la Agudeza, y cultura de tus obras, procura de censurar como Tacito, ponderar como Valerio, reparar como Floro, proporcionar como Paterculo, aludir como Tulio, sentenciar como Seneca, y todo como Plinio". ${ }^{196}$

A diversidade de estilos continua a ser debatida no discurso LXII da obra do jesuíta espanhol, ressaltando-se que há outros dois gêneros de estilo: o natural e o artificial. São eles assim definidos:

Otros dos generos de Estilo ay celebres, muy altercados de los valientes gustos, y son el Natural, y el Artificial, aquel liso, corriente, sin afectacion, pero proprio, casto, y terso: este pulido, limado, con estudio, y atencion: aquel claro, este dificultoso. Aquel dizen sus valedores es el proprio, grave, decente, en èl hablamos de veras, cõ èl hablamos a los

\footnotetext{
192 Carvalho, M. S. F. de. Poesia de Agudeza em Portugal, op.cit., p.211. Desenvolveremos essa afirmação mais adiante, quando examinarmos os Discorsi dell'Arte Poetica de Tasso.

193 "Importa mucho el pensar al uso, no menos que la gala del Ingenio: para mi gusto la agradable alternacion, la hermosa variedad; que si per tropo variar natura e bella, mucho mas el Arte". (Gracián, B. Agudeza y Arte de Ingenio, op.cit., p.369).

194 Idem, p.370.

195 Idem, ibidem.

196 Idem, p.374.
} 
Principes, y personages autorizados; èl es eficaz para persuadir. y assi muy proprio de Oradores, y mas Christianos, es gustoso, porque no es violento, es substancian, verdadero, y assi el mas apto para el fin del hablar, que es darnos a entender. El Artificioso, dizen sus sequazes, es mas perfecto, que sin el Arte siempre fue la naturaleza inculta, y basta; es sublime, y assi mas digno de los grãdes Ingenios: mas agradable, porque junta lo dulce, con lo vtil, como lo han platicado todos los varones Ingeniosos, y eloquentes. ${ }^{197}$

Além do natural e do artificial ou artificioso, há um estilo culto, bastardo e aparente, "que pone la mira en sola la colocacion de las palabras, en la pulideza material de ellas, sin alma de Agudeza, usando de encontrados, y partidos, cõceptos de alforxa"; ${ }^{198}$ e entre o natural e o culto, há ainda um estilo médio, que "ni del todo se descuyda, ni del todo se remõta de frase substãcial, y llena". ${ }^{199}$ Esses diferentes gêneros de estilo são exemplificados com comentários sobre diversos autores modernos; porém, o estilo de cada autor é qualificado de tal forma que parece menos adequado enquadrálo, simplesmente, num daqueles gêneros do que considerá-lo um diferente estilo, sendo, portanto, aquela variedade - assunto principal do discurso anterior (LXI) do tratado de Gracián - reafirmada e ampliada com os comentários acerca das especificidades de cada autor e de seus respectivos modelos, como se observa nos seguintes exemplos: "Escrive el Doctor Babia con estilo claro, pero muy terso, y elegante; Cabrera es ya mas afectado"; 200 "El Marques Virgilio Malvezi (...) junta el estilo sentencioso de los Filosofos con el Critico de los Historiadores, y haze vn mixto admirado: parece un Seneca que historia, y vn Valerio que filosofa"; 201 "El Estilo del sutil Diego Lopez de Andrade Agustiniano, es todo delicadeza, va siempre conceteando, como su Gran Padre Agustino en el Sermon de los Inocentes, Ambrosio en el de Santa Ines, y S. Chrysologo en el de la Madalena"; 202 "El grave, el magestuoso, y muy señor estilo, imitador del de S. Leon Papa, es sin duda el del celebre Doctor D. Frãcisco Filho". ${ }^{203}$

Desse modo, nota-se que os estilos são vários, pois são diversos os conceitos, os autores, os modelos, os gêneros. Com relação aos gêneros, aliás, é foco deste nosso

\footnotetext{
${ }^{197}$ Idem, pp.374-375.

198 Idem, p.375.

199 Idem, p.378.

${ }^{200}$ Idem, p.380.

${ }^{201}$ Idem, ibidem.

${ }^{202}$ Idem, p.382.

${ }^{203}$ Idem, ibidem.
} 
trabalho discutir a poesia lírica e, por isso, é preciso questionar se há um estilo que lhe seja mais conveniente, ou melhor, se há um estilo especificamente lírico. Para tanto, os referidos Discorsi dell'Arte Poetica de Tasso apresentam interessantes argumentos. Assim, o estilo do poeta lírico deve ser florido e ornado, como já mencionamos no fim do capítulo anterior:

Lo stile del lirico poi, se bene non così magnifico como l'eroico, molto più deve essere fiorito ed ornato: la qual forma di dire fiorita (come $\mathrm{i}$ retorici affermano) è propria della mediocrità. Fiorito deve essere lo stilo del lirico: e perché più spesso appare la persona del poeta, e perché le materie che si pigliano a trattare per lo più sono, le quali, inornate di fiori e di scherzi, vili ed abiette si rimarrebbono: onde se per aventura fosse la materia morata trattata con sentenze, sarà di minor ornamento contenta. ${ }^{204}$

O estilo do lírico é florido, porque é próprio da "mediocridade". Essa mediocrità pode ser mais bem compreendida quando Tasso afirma que são três os estilos (divisão essa que ressoa aquela dos três genera da Rhetorica ad Herennium): magnífico (magnifico), humilde (umile) e mediano ou medíocre (mediocre). O mediano - aquele que é, evidentemente, o mais adequado à "mediocridade" do estilo florido e ornado da poesia lírica - define-se como um meio-termo entre o magnífico e o humilde, participando de um e de outro: "Lo stile mediocre è posto fra 'l magnifico e 'l umile, e dell'uno e dell'altro partecipa. Questo non nasce dal mescolamento del magnifico e dell'umile, che insieme si confondano; ma nasce o quando il sublime si rimette o l'umile s'inalza". ${ }^{205}$ Por isso, os conceitos e a elocução do estilo mediano são aqueles que excedem o uso comum e ordinário, mas que não têm tanta força como se busca no magnífico. E o que excede, particularmente, o modo ordinário de falar é a vagueza (vaghezza) nos floridos ornamentos dos conceitos e da elocução e na doçura e suavidade da composição, sendo todas aquelas figuras "d'una accurata e industriosa diligenzia", as quais o humilde dicitore não ousa utilizar e nem se reputam dignas ao magnífico, convenientes ao mediano. Porém, ao usar tais floridos ornamentos, pode-se incorrer no vício vizinho à mediocrità: a afetação (affetazione), que leva à saciedade e ao fastio. Além disso, o estilo mediano não move tão fortemente os ânimos quanto o magnífico,

\footnotetext{
${ }^{204}$ Tasso, T. Discorsi dell'Arte Poetica, op.cit., p.395.

${ }^{205}$ Idem, p.401.
} 
nem mostra com tanta "evidência" o que narra, mas deleita com um suave temperamento. Isso não quer dizer, no entanto, que no mediano prescinde-se da enargeia, pois é necessário a todos os estilos, enquanto instrumentos de imitação, pôr as coisas imitadas diante dos olhos, como se os ouvintes ou leitores estivessem vendo-as: "Stando che lo stile sia un instrumento con 'l quale imita il poeta quelle cose che d'imitare si ha proposte, necessaria è in lui l'energia: la quale sì con parole pone innanzi a gli occhi la cosa che pare altrui no di udirla, ma di vederla". ${ }^{206}$ Essa enargeia ou euidentia, fundamental a qualquer estilo, é assim explicada por João Adolfo Hansen:

O Anônimo da Retórica para Herênio (IV, 19) e Cícero (Partitiones oratoriae VI, 18, 22; De oratore III) escrevem que o discurso ilustre ou brilhante é obtido pelo uso de palavras escolhidas (delecta), de metáforas (traslata), de hipérboles (supralata) e de sinônimos (duplicata). Tais palavras produzem a evidentia ou a visualização imaginosa da matéria tratada no discurso. De novo, Aristóteles: para estimular o pathos em si mesmo e nos ouvintes, o orador que pretende qualificar determinado assunto produz representações chamadas phantasiai (Retórica, I, 3, 1358 b). Retomando Aristóteles e Cícero, Quintiliano escreve, na Institutio oratoria 6, 2, 29, que as imagens fantásticas são produzidas pelo engenho e que este é cultivado com o exercício da imitação das auctoritates dos vários gêneros. A figura das fantasias é a evidentia, como disse, feita como descrição detalhada de um objeto por meio da enumeração ornada de suas particularidades reais ou fantásticas. ${ }^{207}$

Também para Tasso, a enargeia ou euidentia consiste numa descrição detalhada do objeto, ou melhor, é uma virtù que nasce "da una accurata diligenza di descrivere la cosa minutamente". ${ }^{208}$ Essa virtù é imprescindível na epopeia, especialmente nas partes patéticas, já que tal diligente narração é instrumento principal para mover o afeto.

Todavia, não é o maior ou menor grau de "evidência" o que diferencia o estilo épico do lírico. Isso porque, os estilos nascem dos conceitos e, portanto, são os diferentes conceitos que determinam os diversos estilos: "No pensamento poético de

\footnotetext{
${ }^{206}$ Idem, ibidem.

${ }^{207}$ Hansen, J. A. "Retórica da agudeza", op.cit., p.320.

${ }^{208}$ Tasso, T. Discorsi dell'Arte Poetica, op.cit., p.401.
} 
Tasso, o estilo depende dos conceitos, e estes no lírico e no épico são sempre diversos, pois embora esses gêneros tratem por vezes das mesmas coisas, não usam entretanto os mesmos conceitos". ${ }^{209}$ Para sustentar essa conclusão, é preciso discordar da opinião de Dante, para quem o estilo não nasce do conceito, e sim das "vozes" (voci). Essa opinião baseia-se numa autonomia das palavras em relação aos conceitos e, por isso, seriam elas, e não eles, que determinariam os estilos. Mas, para Tasso, recorrendo à doutrina aristotélica, os conceitos são o fim e, consequentemente, a forma das palavras e das "vozes"; desse modo, visto que a forma "non deve essere ordinata in grazia della materia", nem depender dela, os conceitos não devem depender das palavras: "anzi tutto il contrario è vero, che le parole devono pendere da' concetti e prender legge da quelli". 210

É necessário refutar também a suposição de que, sendo as mesmas coisas tratadas tanto pela épica como pela lírica, seria a elocução que distinguiria uma e outra sorte de poesia; assim, nasceria o estilo da elocução, e não dos conceitos. Tasso responde a essa objeção pautando-se, mais uma vez, pela autoridade de Aristóteles e reafirmando a "grandissima differenza" que há entre as noções de "coisas", "conceitos" e "palavras" ou "vozes":

Cose sono quelle che sono fuori de gli animi nostri e che in se medesime consistono. I concetti sono imagini delle cose che nell'animo nostro ci formiamo variamente, secondo che varia è l'imaginazione degli uomini. Le voci ultimamente sono imagini delle imagini: cioè che siano quelle che per via dell'udito rappresentino a l'animo nostro i concetti sono ritratti da le cose. ${ }^{211}$

Porém, pode-se ainda contra-argumentar que se o estilo nasce dos conceitos e se os conceitos do poeta heroico e do lírico são os mesmos, seria o mesmo o estilo de um e de outro. De acordo com Tasso, esse raciocínio está equivocado, pois o heroico e o lírico nunca usam os mesmos conceitos, embora, por vezes, tratem das mesmas coisas (por exemplo, dos deuses, dos heróis e das vitórias). Portanto, é da variedade dos conceitos que nasce a diversidade do estilo, e não da variedade das coisas tratadas.

\footnotetext{
${ }^{209}$ Carvalho, M. S. F. de. Poesia de Agudeza em Portugal, op.cit., p.211.

${ }^{210}$ Tasso, T. Discorsi dell'Arte Poetica, op.cit., p.403.

${ }^{211}$ Idem, p.405.
} 
Assim, a matéria da lírica não é determinada, podendo o poeta lírico versar sobre qualquer matéria que lhe ocorra, mas sempre com os conceitos que lhe são próprios, não comuns ao trágico e ao épico; e é dessa variedade de conceitos que se deriva a variedade de estilos que há entre o épico e o lírico. Por isso, a especificidade da poesia lírica não está na doçura do "número", na distinção das palavras, na vagueza e no esplendor da elocução, na pintura das metáforas e de outras figuras; o que caracteriza a lírica, na verdade, é a suavidade, a graça, a amenidade dos conceitos, qualidades essas das quais dependem aquelas outras. ${ }^{212}$ Enfim, conclui Tasso:

Appare dunque che la diversità dello stile nasce de la diversità de' concetti: i quali sono diversi nel lirico e nell'epico, e diversamente spiegati. Né si conclude che da' concetti non nascano gli stili perché, trattando i medesimi concetti il lirico e l'epico, diversi nondimeno siano gli stili. Perché non vale: tratta le medesime cose, adunque tratta i medesimi concetti, come di sopra dichiarammo: ché ben si può trattare la medesima cosa con diversi concetti. ${ }^{213}$

Dessa maneira, quando o estilo (do) heroico trata de conceitos líricos, faz-se ele próprio lírico. Entretanto, ressalta o autor no fim de seus Discorsi dell'Arte Poetica que embora o poeta lírico use, às vezes, o estilo magnífico e o poeta épico, o mediano ou o humilde, o estilo do lírico, resguardando-se a "intezione principale", será sempre mediano e do épico, magnífico.

Na poesia seiscentista, contudo, esses conceitos líricos são também engenhosos e agudos, nos termos das referidas discussões de Leitão Ferreira e Gracián. Se o estilo da lírica, como ensina Tasso, é ornado, a agudeza é chamada, no século XVII, dentre outras coisas, de "ornato dialético", conforme a explicação de João Adolfo Hansen: “Como a agudeza resulta de uma operação dialética, como análise, e de uma operação retórica, como elocução, tropo ou figura, os preceptistas do século XVII costumam chamá-la de 'ornato dialético'. E, quando é hermética, como ocorre na poesia magnífica de Góngora, 'ornato dialético enigmático", 214 Ademais, esclarece Adma Muhana, baseando-se, sobretudo, no tratado seiscentista Poesia, e Pintura, ou Pintura, e Poesia de Manuel Pires de Almeida, que o pensamento humano só aparece e expõe a coisa dita

\footnotetext{
${ }^{212}$ Idem, pp.405-406.

${ }^{213}$ Idem, p.409.

${ }^{214}$ Hansen, J. A. "Retórica da agudeza", op.cit., p.318.
} 
"quando a palavra está tão engastada na coisa quanto a alma na letra e o corpo na pintura"; ${ }^{215}$ mas "a letra ou a figura não é pensamento de poema enquanto não dispõe dos elementos que o orlam e adornam de modo que, tornadas símeis, tornem-no fábula: até então, sem cores, sem locução, o pensamento é argumento, ou desenho: espírito sem imagem, entender sem amar, poesia sem pintura". ${ }^{216}$ E é nos leitores ou ouvintes, destinação do poema, que os efeitos e as finalidades da poesia se realizam, mostrandose ornados os pensamentos:

A noção aristotélica de que "o fim é de tudo o que mais importa" a preceptiva seiscentista interpreta-a não só no sentido das finalidades da fábula como também das da destinação da poesia. Como o leitorespectator é a quem se destina o poema, é nele que os efeitos da poesia se sucedem e onde as finalidades da mesma confluem: também nele os pensamentos serão ornados. Não sem motivo a transformação da catarse aristotélica para o "deleitar ensinando" horaciano passa por entre os múltiplos sentidos que a unidade do poema e as finalidades da poesia podem adquirir ao encontrarem sua destinação. ${ }^{217}$

Deleitar ensinando é ao que visa a poesia lírica seiscentista, cujo estilo florido e ornado funda-se em conceitos líricos, engenhosos e agudos, sendo o amor uma de suas principais matérias, para deleite e instrução dos leitores e ouvintes.

Contudo, esse estilo lírico é também, por vezes, "insolente", como o refere o Manuel de Faria e Sousa poeta, em um dos "romances portugueses" da parte V de sua Fuente de Aganipe o Rimas Varias. Aliás, sobre essa pouco estudada obra poética do comentador seiscentista de Camões nos informa Ana Hatherly, com base nos trabalhos de Arthur L.-F. Askins, que

Faria e Sousa preparou duas versões de Fuente de Aganipe: a primeira, publicada entre 1624 e 1627 e de que nenhuns manuscritos parecem ter sobrevivido, era supostamente constituída por seis volumes; a segunda versão inicialmente continha seis partes em 1640 e foi depois alargada

\footnotetext{
${ }^{215}$ Muhana, A. A epopéia em prosa seiscentista: uma definição de gênero. São Paulo: Unesp; Fapesp, 1997, p.304.

${ }^{216}$ Idem, p.306.

${ }^{217}$ Idem, p.307.
} 
definitivamente para sete em 1646. Destas, só as primeiras quatro partes foram publicadas, entre 1644 e $1646 .{ }^{218}$

Como já salientamos, é na parte $\mathrm{V}$, manuscrita, que se encontra o mencionado romance. Ainda que a poesia lírica não seja citada, explicitamente, nesse poema de Faria e Sousa, o "estilo insolente", que enterra vivo o espírito doente daquele que padece tormentos impiedosos, é o deste próprio romance que, lírico, é espécie que faz parte, evidentemente, da lírica em geral. É o que se pode inferir da leitura do texto:

1. Porque mataes tormentos

tam vagarosamente;

poys o vagar nas dores

he dor que maes se sente?

2. Quereys que piedade

vos peça paciente?

Vinde mortaes, e juntos,

vireys piadosamente.

3. Peçovos que em mim sendo

quem soys em toda gente,

algum de vos nam tema

de mim ser delinquente.

4. Porque dar vida a hum triste,

ou morte diligente,

se for piedade dura,

crime será clemente.

5. Nam façaes companhia

a Amor, que manda ardente,

que ou mortalmente viva,

ou morra vivamente.

6. Dayme (se está maes pena

em dalla variamente)

ou vida que me acabe,

ou morte que me alente.

7. Nam espereys que rogue

\footnotetext{
${ }^{218}$ Hatherly, A. "Labirintos da Parte VII da Fuente de Aganipe de Manuel de Faria e Sousa". In: Separata dos Arquivos do Centro Cultural Português. XXI. Paris - Lisboa: Fundação Calouste Gulbenkian, 1985, p.462.
} 
que a vida se me aumente;

que do viver só quero

hum só morrer frequente.

8. Nam me deys vida morta;

que em mal tam eminente,

quem diz que morre acerta,

quem diz que vive mente.

9. Poys tendes começado

seja o penar corrente;

porque he morte insofrivel

a pena intercadente.

10. Olhay que sem limte

agrava quem consente,

presentes mostraes ansias

com morte sempre ausente.

11. De penas, nam de pomos,

sou Tantalo evidente;

como ausente esperando

as que vejo presente.

12. Ja do espirito o corpo

nam he prisam sòmente;

poys ja morto he sepulcro

do espirito doente.

13. Nam lamenta o enterro:

mas justo he que lamente,

o ver que o enterre vivo

hum estilo insolente.

14. Aa sepultura seja

a morte antecedente:

e seja logo a morte,

se quereys vos, vehemente. ${ }^{219}$

${ }^{219}$ Fvente de Aganipe o rimas varias [Manuscrito]: divididas en siete partes / de Manuel de Faria i Sousa Cavallero de la Orden de Christo i de la Casa Real. Lisboa: Biblioteca Nacional, cod.13141, fls.218$218 v$ v É interessante reproduzir as "notas" da Biblioteca Nacional de Lisboa que buscam esclarecer as especificidades desse códice: "Ms. com correcções e acresc. Parece tratar-se do ms. da 2a ed. desta obra (En Madrid : por Juan Sanchez impressor, 1644), corrigido e acresc. para uma ed. posterior (o ms. integra 6 docs. soltos referentes às licenças dos qualificadores do Santo Ofício de imp. da 1a, 3a e 6a partes da obra, datados de 1677-1678). Contém apenas as Partes 1 1 $-6^{\mathrm{a}}$. Pert.: 'Da Livraria do Doutor Joaquim de Carvalho' (ex-libris). Enc. em perg." 
Para compreender melhor por que esse estilo é chamado de insolente, é válido destacar, em princípio, que Bluteau apresenta diferentes possíveis acepções da palavra "insolente" em seu Vocabulário: "arrogante", "soberbo", “desavergonhado", "desaforado", "desusado", "extraordinário", "que raras vezes acontece". Para exemplificar o emprego de tal vocábulo com o sentido de "desusado" e "extraordinário", Bluetau cita um preceito da Origem da Língua Portuguesa de Duarte Nunes de Leão: "Os homens polidos devem escusar de fallar palavras insolentes". 220 Tanto as palavras como os estilos, portanto, podem ser ditos "insolentes", seja por serem raros, desavergonhados ou arrogantes. Assim, o estilo do referido poema lírico de Faria e Sousa se qualifica insolente, porque não é digno de tratar de assunto tão elevado - os tormentos do espírito -, sendo, por isso mesmo, soberbo na sua pretensão e desaforado, isto é, indecoroso na sua realização. Ademais, o próprio "gênero de composição" (utilizando-se a expressão de Faria e Sousa), ou seja, o romance não é digno de prestígio e apreço na opinião do poeta, pois é uma composição típica de homens pouco cultivados na arte de fazer versos, como se verifica em seu prólogo dessa quinta parte da Fuente de Aganipe ("Prologo - discurso acerca de los generos de composiciones que ay en esa Parte quinta"):

Pareceme el Romance una composicion insulsa; i empleo de Segadores, i Arrieros, que en queriendo intentar algo de numero, luego hazen una copla de Romance. Devió llamarse assi por no tener consonantes, pues romance se llama vulgarmente la prosa, i poco más de prosas son los Romances. (...) Alfin no soy enamorado de los Romances, por mas que sean felices. ${ }^{221}$

Com tal estilo insolente, a persona lírica, cujo espírito atormentado e doente está preso a um corpo morto, lamenta sua triste condição de "vida morta", que consiste num só penar sem fim. Por isso, compara-se a Tântalo, mas, engenhosamente, diferenciando-se dele ao ressaltar que os pomos que sempre lhe escapam são suas penas, sendo ainda mais doloroso o suplício da persona lírica do que aquele de Tântalo, como

\footnotetext{
${ }^{220}$ Bluteau, R. Vocabulario Portuguez, \& Latino, op.cit., volume 4, verb. "insolente", p.149.

${ }^{221}$ Fvente de Aganipe o rimas varias, op.cit. Parte Quinta. "Prologo", parágrafos 23-24.
} 
se depreende dos agudos versos finais da décima primeira copla ${ }^{222}$ do poema: "como ausente esperando / as que vejo presente." Considerando-se equívoco ou homônimo ${ }^{223}$ o vocábulo "como" nesses versos, num primeiro caso, em que "como" é conjunção, a persona lírica sofre em dobro, pois embora as penas presentes atormentem-na da mesma forma que os pomos inalcançáveis faziam ao faminto Tântalo, ela, como se estivesse ausente, também já sente os efeitos das penas futuras, sendo sua única esperança viva esse sofrer constante, ao qual apenas a rogada morte pode dar fim: "Aa sepultura seja / a morte antecedente: / e seja logo a morte, / se quereys vos, vehemente". Num segundo caso, em que "como" é flexão verbal, numa metáfora aguda, a persona lírica come as penas presentes, como se fossem os pomos de Tântalo, porém sendo penas, não causam saciedade, e sim mais dores; tal martírio se intensifica na medida em que, enquanto ausente que espera, aquela persona, além de padecer comendo as penas que a ferem no presente, padece aguardando aquelas que ela não pode ver nem provar, mas que são certas e futuras, até que a morte acabe com essa impiedosa fome, saciada apenas com mais dolorosos pomos.

Desse modo, insolente e agudo é o estilo lírico com o qual se descrevem esses constantes tormentos que, mesmo não sendo caracterizados como amorosos, são relacionados com o amor: este surge, na quinta copla, como um tirano de ingrata companhia, ainda mais cruel do que aqueles tormentos, "que manda ardente, / que ou mortalmente viva, / ou morra vivamente". Essa pungente contradição que impõe o amor, de viver morrendo e vivendo morrer, é tópica ${ }^{224}$ da poesia lírico-amorosa. Assim,

\footnotetext{
${ }^{222}$ Preferimos utilizar o termo "copla", pois é o mesmo que emprega Faria e Sousa, por exemplo, no já citado prólogo da quinta parte da Fuente de Aganipe: "Un Romance amoroso no deve exceder de 24. coplas, ni baxar de 12." (parágrafo 38). Além disso, também é o vocábulo "copla" que utiliza Juan Diaz Rengifo em sua Arte Poetica Española (Madrid: Viuda de Alonso Martin, 1628). Finalmente, o uso de tal termo em português parece pertinente tendo em vista a sua definição em Bluteau: "COPLA. (Termo da Poesia vulgar). Derivase do vocabulo latino Copula, que quer dizer Uniaõ, porque em huma Copla se unem, \& se ajuntaõ os versos, com oraçaõ taõ completa, que naõ depende da Copla, que se segue. Na Copla há duas cousas, certo numero de versos, \& certa consonancia entre os fins delles, \& segundo a variedade destas duas cousas, se differençaõ, \& variaõ as Coplas." (Vocabulario Portuguez, \& Latino, op.cit., volume 2, verb. "copla", pp.533-534).

${ }^{223}$ Segundo Bluteau, "Homonymo, \& Equivoco saõ o mesmo" (Idem, verbete "Homonymo"). João Franco Barreto, também citado por Bluteau, define os "homônimos" na Ortografia da Língua Portuguesa da seguinte maneira: "os nomes onominos são aquelles que significam muytas cousas, como este nome palma, que significa a arvore, a vitoria, \& a palma da mã. Carneyro, que significa o animal quadrupede, o bichinho, que dá nas favas, \& outros legumes, \& a sepultura: Gallo significa a ave, o Francez, o palmã da cabeça, \& certo peyxe, \&c. \& dizẽse onominos, por isto mesmo, que sendo ũ nome, tẽ diversas significações. Os Latinos o escrevem aspirado, Hononymos." (Ortografia da lingua portugueza / per Joam Franco Barretto. Em Lisboa: na officina de Joam da Costa, 1671, p.37).

${ }^{224}$ Conforme Curtius, "no antigo sistema da retórica, é a tópica o celeiro de provisões. Contém os mais variados pensamentos: os que podem empregar-se em quaisquer discursos e escritos em geral" (Curtius,
} 
por exemplo, numa sextina, ${ }^{225}$ Foge-me, pouco a pouco, a curta vida, atribuída a Camões, ${ }^{226}$ a persona lírica, sofrendo pela ausência (dos olhos) da amada ("Ó fermosos, gentis e claros olhos, / Cuja ausência me move a tanta pena"), exprime o seu penar no seguinte verso: "Morrendo estou na vida, e em morte vivo". ${ }^{227}$ O próprio Faria e Sousa, ao comentar esse verso da sextina camoniana, afirma que "esto de vivir muriendo, y viviendo morir" é “cosa tan trillada de todo Poeta, y aun versificador", evidenciando a relevância desse topos na poesia lírica. ${ }^{228}$ Entretanto, é nos comentários ao soneto Tanto de meu estado me acho incerto ${ }^{229}$ que Faria e Sousa busca esclarecer em que consiste tal tópica e elenca suas diversas ocorrências na lírica camoniana.

Elucida, então, o comentador que o soneto de Camões, Tanto de meu estado me acho incerto, é imitação do soneto de Petrarca, Pace non trovo, et non ò da far guerra. ${ }^{230}$ Se da leitura deste modelo petrarquista "se infiere que su amor con Laura era

E. R. Literatura Européia e Idade Média Latina. Tradução de Teodoro Cabral, com a colaboração de Paulo Rónai. 2a ed. Brasília: Instituto Nacional do Livro, 1979, p.82).

${ }^{225}$ Sobre a história da sextina e sua presença na produção poética portuguesa dos séculos XVI e XVII, veja-se o trabalho de Antônio Cirurgião: A sextina em Portugal nos séculos XVI e XVII. Lisboa: Instituto de Cultura e Língua Portuguesa. Biblioteca Breve / Volume 126. $1^{\text {a }}$ edição, 1992. O autor, inclusive, faz uma análise da sextina camoniana à qual nos referimos (Idem, pp.72-79).

${ }^{226}$ Essa sextina está nas Rhythmas de Luis de Camoes. Em Lisboa: por Manoel de Lyra, 1595, fls. 42-43. Nas Rimas Várias de Camões, comentadas por Faria e Sousa tal sextina também aparece: Rimas Varias de Luis de Camoens... Comentadas por Manuel de Faria y Sousa. Segunda Parte. Lisboa: En la Imprenta Craesbeeckiana, 1688, pp.202-205.

227 "Foge-me, pouco a pouco, a curta vida, / Se por acaso é verdade que inda vivo; / Vai-se-me o breve tempo de ante os olhos; / Choro pelo passado; e, enquanto falo, / Se me passam os dias passo e passo. / Vai-se-me, enfim, a idade, e fica a pena. / Que maneira tão áspera de pena! / Que nunca ũa hora viu tão longa vida / Em que possa do mal mover-se um passo. / Que mais me monta ser morto que vivo? / Pera que choro? Enfim, pera que falo, / Se lograr-me não pude de meus olhos? / Ó fermosos, gentis e claros olhos, / Cuja ausência me move a tanta pena / Quanta se não compreende enquanto falo! / Se, no fim de tão longa e curta vida, / De vós me inda inflamasse o raio vivo, / Por bem teria tudo quanto passo. / Mas bem sei que primeiro o extremo passo / Me há de vir a cerrar os tristes olhos, / Que Amor me mostre aqueles por que vivo. / Testemunhas serão a tinta e pena / Que escreverão de tão molesta vida / O menos que passei, e o mais que falo. / Oh! que não sei que escrevo, nem que falo! / Que, se de um pensamento noutro passo, / Vejo tão triste gênero de vida / Que, se lhe não valerem tanto os olhos, / Não posso imaginar qual seja a pena / Que traslade esta pena com que vivo. / Na alma tenho contín[u]o um fogo vivo, / Que, se não respirasse no que falo, / Estaria já feita cinza a pena; / Mas, sobre a maior dor que sofro e passo / Me temperam as lágrimas dos olhos; / Com que, fugindo, não se acaba a vida. / Morrendo estou na vida, e em morte vivo; / Vejo sem olhos, e sem língua falo; / E juntamente passo glória e pena." (Citamos o texto com base na já referida edição: Camões, L. de. Obra Completa, op.cit., pp.327-328).

${ }_{228}$ Rimas Varias. Segunda Parte, op.cit., p.204.

229 "Tanto de meu estado me acho incerto, / Que em vivo ardor tremendo estou de frio; / Sem causa, juntamente choro e rio; / O mundo todo abarco e nada aperto. / É tudo quanto sinto um desconcerto; / Da alma um fogo me sai, da vista um rio; / Agora espero, agora desconfio, / Agora desvario, agora acerto. / Estando em terra, chego ao Céu voando; / Nũa hora acho mil anos, e é de jeito / Que em mil anos não posso achar ũa hora. / Se me pergunta alguém porque assi ando, / Respondo que não sei; porém suspeito / Que só porque vos vi, minha Senhora." (Camões, L. de. Obra Completa, op.cit., p.299).

230 "Pace non trovo, et non ò da far guerra; / e temo e spero; et ardo e son un ghiaccio; / et volo sopra'l cielo et giaccio in terra; / et nulla stringo, et tutto 'l mondo abbraccio. / Tal m'à in pregion, che non m'apre né serra, / né per suo mi riten né scioglie il laccio; / et non m'ancide Amore, et non mi sferra, / né mi vuol vivo, né mi trae d'impaccio. / Veggio senza occhi, et no ò lingua, et grido; / et bramo di perir, et 
Platonico, o divino; y que la hermosura della le servia de imagen en la qual contemplando la divina hermosura, divinamente la amava", é força que seja também platônico ou divino o amor daquele poema camoniano, "porque ambos son una misma cosa; supuesto que no solamente es imitacion este de aquel, si no traslado a la letra en algunos lances: y los otros sino son los mismos son semejantes, como procedidos de una propria Idea". Porém, ressalta Faria e Sousa que no soneto de Petrarca "ay un lugar importante que falta en este de mi Poeta", e se trata, justamente, do topos "viver morrendo e vivendo morrer", que está presente nos seguintes versos do poeta de Laura: “et non m'ancide Amore, et non mi sferra, / né mi vuol vivo, né mi trae d'impaccio". Essa falta, no entanto, é suprida por diversas outras composições da lírica camoniana em que essa morte viva ou vida morta é glosada, sendo mencionado, inclusive, aquele verso ("Morrendo estou na vida, e em morte vivo") da sextina Foge-me, pouco a pouco, a curta vida. Afirma, enfim, o comentador que, nesses "lugares", o "seu Poeta" mostra "que los que aman de Amor divino, ni viven ni mueren; y si mueren en si, viven en lo amado por la transformacion amorosa". 231

Essa tópica platônico-cristã-amorosa, de morrer em vida e viver na morte, é tratada com estilo agudo na poesia lírica seiscentista, como se observa nestas duas décimas de Violante do Céu, que glosam o mote "muriendo del mal que vivo / no vivo del mal que muero":

\footnotetext{
Idolatrando un desdén

que a mi amor es sólo igual

vivo de un bien, que es mi mal,

muero de un mal que es mi bien;

pero contemplando en quien

del bien, y del mal es motivo

tanto me eleva lo altivo

que mil veces considero

(viviendo del bien) que muero

(muriendo del mal) que vivo.

Pero como el bien que estimo

es este mal que padezco,
}

\footnotetext{
cheggio aita; / et ò in odio me stesso, et amo altrui. / Pascomi di dolor, piangendo rido; / egualmente mi spiace morte et vita: / in questo stato son, donna, per voi.” (Petrarca, F. Canzoniere, op.cit., p.186).

${ }^{231}$ Rimas Varias. Primeira Parte. Lisboa: En la Imprenta de Theotonio Damaso de Mello Impressor de la Casa Real, 1685, pp.27-28.
} 
ni con la muerte fenezco,

ni con la vida me animo:

no piensen pues que reprimo

el mal, o el bien que venero,

mas sepan, que porque quiero

al valor más excesivo

no muero del bien, que vivo,

no vivo del mal, que muero. ${ }^{232}$

No mote glosado, o "mal" é tanto razão de vida quanto de morte, mas se está vinculado à vida, é um constante e doloroso morrer, e se à morte, impede que dele se viva. Contudo, esse mal, antes indeterminado, é especificado como amoroso na primeira décima, acrescentando-se a ele seu conceito oposto: o "bem"; isso faz com que a elocução do poema centre-se em tal oposição e se constitua, fundamentalmente, por antíteses como "vivo de un bien, que es mi mal, / muero de un mal que es mi bien". Ainda na primeira décima, o "mal" e o "bem" da persona lírica são associados, respectivamente, ao desdém e ao amor, sendo causa de ambos o amado. Assim, a contradição entre bem e mal se desfaz no seu elevado motivo amoroso, pois o amor e o penar tem uma mesma nobre causa: o amado; mas se torna mais complexa quando se consideram os contraditórios efeitos do amor e do desdém no amante, que se sente morrer vivendo do bem (amoroso) e que só se julga vivo por estar morrendo do mal (também amoroso).

A segunda décima continua a aproximar, agudamente, os conceitos opostos "bem" e "mal", "vida" e "morte"; essa aproximação, no entanto, é de tal forma intensificada que acaba por se tornar uma identificação entre o bem e o mal da persona lírica amante: “...el bien que estimo / es este mal que padezco"; por isso, sendo amar o mesmo que padecer, a vida e a morte lhe são indiferentes. Então, não há por que refrear o mal ou o bem de amor, que se confundem e são ambos tão venerados, ainda mais por ser "o valor mais excessivo", isto é, o amor divino o que deseja a persona lírica. Desse modo, almejando o amor mais excelente, esse amante exemplar não morre do bem que lhe dá vida, nem vive do mal que o mata: bem e mal enfim diferenciados.

Como verificamos nos comentários de Faria e Sousa à lírica camoniana, no amor platônico ou divino, que se encontra naqueles referidos sonetos de Petrarca e

\footnotetext{
${ }^{232}$ Violante do Céu. Rimas Várias. Introdução, notas e fixação do texto de Margarida Vieira Mendes. Lisboa: Editorial Presença, 1994, p.135.
} 
Camões e (podemos acrescentar) também nessa composição de Violante do Céu, ama-se divinamente ao se contemplar na beleza do ser amado a imagem da beleza divina. Essa concepção platônico-cristã do amor, como se sabe, é amplamente desenvolvida e difundida por Marsílio Ficino no século XV. Comentando o Fedro, por exemplo, Ficino afirma que o amor de que tratam Platão e São Paulo é um mesmo e único amor: aquele da Beleza, que é Deus. ${ }^{233}$ Nesse mesmo sentido, em seu mais importante texto sobre esse tema, o Commentarium in Convivium Platonis ou simplesmente De Amore, ${ }^{234}$ Ficino, elucidando de que modo Platão expõe as coisas divinas ("quomodo Plato de rebus diuinis exponatur"), cita uma suposta carta do filósofo ao rei Dionísio na qual se evidencia que Deus é a causa de todas as coisas belas, sendo princípio e origem de toda beleza: "Hoc mysterium in epistola ad Dionysium regem Plato significauit, cum deum affirmauit pulchrorum omnium causam, quasi totius pulchritudinis principium et originem" (De Amore, II, 4). Porém, Ficino ressalta, talvez seguindo Plotino (Enéadas, $\mathrm{V}, 1,7)$, que Platão determina como último grau da ordem das coisas divinas a alma; logo, exclui a matéria. Assim, as verdadeiras coisas (uere res) são as ideias (idee), as razões (rationes) e as sementes (semina), enquanto as formas dos corpos parecem mais sombras do que coisas "reais"; por isso, da mesma maneira que a sombra de um corpo não indica a figura clara e exata dele, os corpos não podem nos mostrar a natureza própria das coisas divinas. ${ }^{235}$

Todavia, a beleza divina resplandece em tudo e é em tudo amada. Isso porque, o bem é precisamente a existência supereminente de Deus, e a beleza um ato ou um raio que, nascido Dele, penetra em todas as coisas: da "mente angélica" até a matéria dos corpos. Dessa maneira, aquele que contempla e ama a beleza, mesmo quando ela se mostra menos reluzente nos corpos, vê e ama neles não a sua matéria, mas o esplendor divino e, através dele, Deus em si. Portanto, o impetus do amante não é apaziguado nem pela visão nem pelo toque de nenhum corpo, pois quem ama não deseja este ou aquele

\footnotetext{
${ }^{233}$ Como é constatado por Jean Festugière: "Dans son Commentaire sur le Phèdre, il [Ficino] affirme que l'amour dont parlent Platon et saint Paul n'est qu'un seul amour: l'amour de la Beauté, qui est Dieu, «Deum tandem amamus ut pulchrum, quem jam pridem dilexaramus ut bonum». (Festugière, J. La philosophie de l'amour de Marsile Ficin - et son influence sur la littérature française au XVI ${ }^{e}$ siècle. Paris: J. Vrin, 1941, p.22).

${ }^{234}$ Para as citações do texto em latim, utilizaremos a seguinte edição: Commentaire sur le Banquet de Platon, De l'Amour - Commentarium in Convivium Platonis, De Amore. Texte établi, traduit, présenté et annoté par Pierre Laurens. Paris: Les Belles Lettres, 2002.

235 "Vere namque res, idee, rationes et semina sunt. Corporum uero forme, umbre rerum potius quam uere res esse uidentur. Quemadmodum uero corporis umbra exactam atque distinctam corporis figuram non indicat, ita corpora diuinorum naturam propriam non demonstrant" (De Amore, II, 4).
} 
corpo, e sim o esplendor da majestade divina refletido nos corpos: e é tal esplendor que maravilha, que atrai, que provoca estupefação. ${ }^{236}$

No entanto, salienta Ficino que, mesmo tendo origem divina, ou melhor, sendo desejo de fruir a beleza divina, o amor é chamado por Platão de "coisa amarga", pois quem ama morre; e por Orfeu de "doce-amargo" (glukupikron), ${ }^{237}$ visto que o amor é uma morte voluntária: enquanto morte, ele é uma coisa amarga, mas por ser voluntária, ele é doce. Esclarece, então, Ficino que quem ama morre, porque o pensamento (cogitatio) do amante, esquecendo-se de si, volta-se continuamente para o amado; e se o amante não tem o pensamento voltado para si, ele não pensa em si mesmo; consequentemente, um animus assim afetado não consegue operar em si mesmo, já que a principal operação do animus é o pensamento. Desse modo, quem não opera em si mesmo, não é/está em si: há uma equivalência entre essas duas coisas, ser e operar, pois não há ser sem operação nem operação que exceda o ser. Dado que ninguém pode operar onde não é/está e, ao contrário, onde quer que alguém seja/esteja pode operar, o animus do amante não é/está em si mesmo, uma vez que ele não age (agit) em si mesmo. Assim, se ele não é/está em si mesmo, ele não vive em si mesmo; logo, quem não vive morre. Por esse motivo, todo aquele que ama está morto em si. ${ }^{238}$

Se o amante está morto em si, ele pode viver, entretanto, no amado. Isso ocorre apenas numa das espécies de amor referidas por Ficino. Quando se trata de amor simples (simplex), o amado não corresponde ao amor do amante, estando este completamente morto, pois não vive nem em si nem no outro. Já quando o amor é mútuo (mutuus), ou seja, quando amante e amado se amam reciprocamente, aquele vive neste e este vive naquele: um revive no outro. Como sintetiza Ficino, "equidem dum te amo, me amantem, in te de me cogitante me reperio, et me a me ipso negligentia mea perditum in te conseruante recupero. Idem in me tu facis." (De Amore, II, 8). Enfim, no

\footnotetext{
236 "Hinc efficitur ut corporis nullius aspectus uel tactu amatoris impetus extinguatur. Non enim corpus hoc aut illud desiderat, sed superni numinis splendorem per corpora refulgentem ammiratur, affectat et stupet." (De Amore, II, 6).

${ }^{237}$ Essa noção antitética do amor como um amargo que é doce ou um doce que é amargo, condensada nesse oximoro de Orfeu, é tópica na poesia lírico-amorosa. No soneto CXVIII do Canzoniere de Petrarca, por exemplo, lê-se o seguinte verso: "L'amar m'è dolce, et util il mio danno" (Canzoniere, op.cit., p.154). 238 "Amorem Plato rem amaram uocat. Nec iniuria, quia moritur quisquis amat. Hunc et Orpheus $\gamma \lambda \nu \chi v ́ \pi \chi \chi \rho o v$, id est, dulce amarum nominat. Quippe cum amor mors uoluntaria sit. Ut mors est, amara res est. Ut uoluntaria, dulcis. Moritur autem quisquis amat. Eius enim cogitatio sui oblita semper in amato se uersat. Si de se non cogitat, in se certe non cogitat. Ideo nec in seipso sic affectus animus operatur, cum precipua operatio animi ipsa cogitatio sit. Qui non in se operatur, nec in seipso est. Equa enim inter sese hec duo, esse et operatio, sunt. Nec esse sine operatione est nec operatio esse ipsum excedit. Nec operatur quisquam ubi non est, et ubicumque est operatur. Non ergo in se amantis est animus, quia in seipso non agit. Si in se non est, nec uiuit etiam in seipso. Qui non uiuit mortuus est. Quare in se mortuus est quicumque amat." (De Amore, II, 8).
} 
amor mútuo, quem ama morre uma única vez em si, porque se negligencia; mas ele ressuscita logo no amado quando este se apodera do amante num pensamento ardente; além disso, o amante ressuscita uma segunda vez quando ele se reconhece no ser amado e não mais duvida de que seja também amado: o amante morre uma vez para ressuscitar duas.

Devido à relevância dessa discussão para compreender aquela tópica da poesia lírico-amorosa, "viver morrendo e vivendo morrer", é pertinente retomar o discurso de Aristófanes no Banquete de Platão, em que o poeta discorre sobre a origem da natureza humana e, consequentemente, do próprio amor (Eros). Com isso, ficará mais evidente aquela já mencionada afirmação de Faria e Sousa sobre o amor platônico ou divino: que aqueles que amam com amor divino, não vivem nem morrem; e se morrem em si, vivem no amado pela transformação amorosa. Assim, Aristófanes ressalta que, antigamente, a natureza humana era muito diferente: havia três sexos distintos, e não apenas dois além do masculino e feminino, havia um terceiro composto desses dois, o andrógino. Esses seres primevos são descritos da seguinte forma:

No todo os homens eram redondos, com o dorso e os flancos como uma bola. Possuíam quatro mãos, igual número de pernas, dois rostos perfeitamente iguais num só pescoço bem torneado, e uma única cabeça com os rostos dispostos em sentido contrário, quatro orelhas, dois órgãos genitais e tudo o mais pelo mesmo modo, como será fácil imaginar. Andavam de pé, como hoje, para qualquer lado; porém, se se dispunham a correr velozmente, faziam como os saltimbancos, que viram em círculo e jogam as pernas para o ar, até completar a volta; e como nesse tempo tinham oito membros para apoiar-se, deslocavam-se com rapidez incrível. (Banquete, XIV, 189e-190a). ${ }^{239}$

Tais homens eram dotados de força e coragem extraordinárias e, por isso, atacaram os deuses, tentando escalar os céus para combatê-los. Zeus, então, para enfraquecer e disciplinar esses seres demasiadamente poderosos e arrogantes, decidiu dividi-los ao meio, "como cortamos ovos com o auxílio de um cabelo" (Idem, XV, 190e). Apolo fez-lhes os ajustes necessários para que eles pudessem sobreviver, inclusive passando para frente os órgãos reprodutores, o que os forçou a procriarem uns

\footnotetext{
${ }^{239}$ Edição utilizada: Platão. O Banquete - Apologia de Sócrates. Tradução de Carlos Alberto Nunes. $2^{\text {a }}$ ed. rev. Belém: EDUFPA, 2001.
} 
nos outros: "se o amplexo ocorria entre homem e mulher, havia geração e propagação da espécie; porém se se dava entre dois seres do sexo masculino, a saciedade os separava por algum tempo, ficando ambos em condições de voltar para suas atividades habituais e de prover às necessidades da vida." (Idem, XV, 191c). Portanto, desde essa divisão, "é inato nos homens o amor de uns para os outros, o amor que restabelece nossa primitiva natureza e que, no empenho de formar de dois seres um único, sana a natureza humana." (Idem, XV, 191d). Cada ser humano, enfim, o é apenas pela metade, mero symbolon, por ter sido partido ao meio, vivendo sempre a buscar a sua outra metade.

Desse modo, aquela "transformação amorosa" referida por Faria e Sousa pode ser compreendida não só como a morte do amante em si para viver no amado, mas também como o reencontro das duas metades repartidas que compunham o ser primevo. $\mathrm{Na}$ poesia lírica, essa matéria é largamente glosada e reinventada, conforme já observamos nos poemas anteriormente mencionados e como podemos verificar neste soneto (XCIV) do Canzoniere de Petrarca, em que a parte perdida (la scacciata parte), num milagre, fugindo de si mesma, chega a um lugar (in parte) onde encontra sua vingança e seu jucundo exílio:

Quando giugne per gli occhi al cor profondo

l'imagin donna, ogni altra indi si parte,

et le vertú che l'anima comparte,

lascian le membra, quasi immobil pondo.

Et del primo miracolo il secondo

nasce talor, che la scacciata parte

da se stessa fuggendo arriva in parte

che fa vendetta e 'l suo exilio giocondo.

Quinci in duo volti un color morto appare,

perché 'l vigor che vivi gli mostrava

da nessun lato è piú là dove stava.

Et di questo in quel dí mi ricordava,

ch'i' vidi duo amanti trasformare,

et far qual io mi soglio in vista fare. ${ }^{240}$

${ }^{240}$ Canzoniere, op.cit., p.127. 
Além disso, é ainda importante recordar que no início de seu discurso no Banquete, Sócrates define como objeto do amor e do desejo "o que não se tem, o que ainda não existe e o de que se carece" (Banquete, XXI, 200e). Eros é, dessa maneira, desprovido de beleza, por ser desejo de possuir o belo. Contudo, as coisas belas são também boas, sendo, por isso, o amor igualmente desprovido de bondade. Reproduzindo, então, os ensinamentos de Diotima, Sócrates esclarece que Eros não é feio nem belo, mas algo entre esses dois extremos; não é, tampouco, imortal nem mortal, e sim um elo intermediário entre os deuses e os homens, um daimon (Idem, XXII-XXIII, 202d-203a). Isso se explica por ser Eros filho de Poros (Riqueza) e Penia (Pobreza), tendo sido concebido no dia em que os deuses celebravam, com um banquete, o nascimento de Afrodite. Eros herdou, portanto, os contrários predicados ou características de seus pais e se tornou "companheiro e servidor de Afrodite, por ter sido gerado no dia do seu nascimento e por ser Afrodite bela e ele naturalmente amante das coisas belas" (Idem, XXIII, 203c). Como um filósofo, enfim, Eros se encontra a meio caminho da sabedoria e da ignorância. Tendo em vista esses motivos, conclui-se que o amor "é o desejo de possuir sempre o bem" (Idem, XXIV, 206a).

Essa identificação entre o belo e o bom não é exclusivamente platônica, pois se verifica no próprio uso corrente da língua grega antiga, conforme salienta Werner Jaeger: "O belo e o bom não passam de dois aspectos gêmeos de uma única realidade, que a linguagem corrente dos Gregos funde numa unidade, ao designar a suprema arete

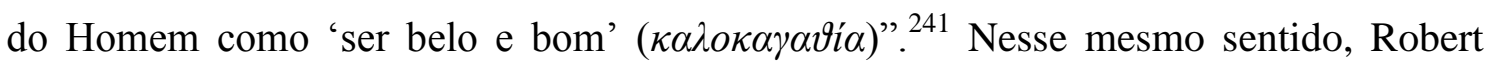
Flacelière destaca que "le mot calos désigne à la fois ce qui est beau et ce qui est noble, et le mot aïschros ce qui est laid et ce qui est honteux. Donc, pour un Grec, la beauté est noblesse et la laideur est stigmate de honte". ${ }^{242}$

No século XVI, essa concordância entre a beleza e a bondade é exposta e defendida, por exemplo, no quarto livro do Cortesão de Castiglione, no discurso de Pietro Bembo. Questionado sobre o fato de o belo nem sempre ser bom, Bembo responde que "não pode existir beleza sem bondade", já que a beleza emana de Deus. Ademais, "a beleza extrínseca é um verdadeiro signo da bondade intrínseca"; dessa forma, é muito raro uma alma ruim habitar um belo corpo. Consequentemente, em

\footnotetext{
${ }^{241}$ Jaeger, W. Paidéia: a formação do homem grego. Tradução de Artur M. Parreira. $4^{\mathrm{a}}$ ed. São Paulo: Martins Fontes, 2001, p.745.

${ }^{242}$ Flacelière, R. L'amour en Grèce. Paris: Hachette, 1960, p.31.
} 
geral, os feios são também maus e os belos, bons. Em suma, afirma Bembo sobre tal concordância, particularmente nos corpos humanos:

Pode-se dizer que o bom e o belo, de certo modo, são a mesma coisa, em especial nos corpos humanos, de cuja beleza creio ser a causa mais próxima a beleza da alma, que, como partícipe daquela verdadeira beleza divina, ilustra e torna belo tudo o que toca, especialmente se o corpo que ela habita não é de matéria tão vil que ela não possa lhe imprimir sua qualidade; por isso a beleza é o verdadeiro troféu da vitória da alma, quando ela, com a virtude divina, domina a natureza material e com seu lume vence as trevas do corpo. ${ }^{243}$

Sendo essa identificação entre a beleza e a bondade fundamental na concepção platônica de amor, definido como o desejo de sempre possuir o belo ou o bom, tal noção de eros pode ser compreendida, portanto, de acordo com Jaeger, como "a suma e o compêndio da aspiração humana ao bem". ${ }^{244}$ Isso porque, só se nomeia "bom" aquilo que é próprio, individual e universalmente, ao ser humano, e "mau" aquilo que lhe é estranho, conforme as palavras de Diotima: "Ninguém se apega, quero crer, ao que lhe pertence, salvo se dermos a denominação de bom ao que nos é próprio e faz parte de nós mesmos, e de mau ao que nos é estranho, porque fora do bem nada mais os homens amam.” (Banquete, XXIV, 205e-206a). Essa concepção platônica de eros pode ser relacionada com o amor a si próprio (philautia) aristotélico, do qual derivam todas as espécies de amizade (philia): "As formas que tomam nossos afetos amistosos em relação ao próximo, e as características pelas quais se definem as diferentes espécies de amizade, parecem derivar de nossos afetos em relação a nós mesmos”. Assim, se o amigo, como o define Aristóteles, é "uma pessoa que deseja e faz o que é bom, ou parece que deseja e faz, por causa de seu amigo", a amizade só pode decorrer de "uma pessoa boa em relação a si mesma", sendo seus afetos em relação aos amigos idênticos aos que ela tem em relação a si própria. Por isso, afirma Aristóteles que, na verdade, "um amigo é um outro eu". (Ética a Nicômaco, IX, 4, 1166a). ${ }^{245}$

\footnotetext{
${ }^{243}$ Castiglione, B. O cortesão. Tradução de Carlos Nilson Moulin Louzada. São Paulo: Martins Fontes, 1997, p.324.

${ }^{244}$ Jaeger, W. Paidéia: a formação do homem grego, op.cit., p.738.

${ }^{245}$ Edição utilizada: Aristóteles. Ética a Nicômacos. Tradução de Mário da Gama Kury. $3^{\text {aed. Brasília: }}$ Editora da Universidade de Brasília, 1999.
} 
Essa noção aristotélica de philautia também ressoa nos debates quinhentistas e seiscentistas sobre o amor, como se nota, por exemplo, no diálogo VI da Corte na Aldeia de Francisco Rodrigues Lobo, cujo tema é a "diferença do amor e da cobiça":

O amante e o cobiçoso não diferem mais no amor que no emprego dele; e para isto me fundo em uma opinião moderna, que tem por si muitas autoridades antigas: e é que nenhuma pessoa ama mais a outra que a si mesma, nem pode ter amor a outrem se primeiro se não amar a si; ${ }^{246} \mathrm{e}$, do amor que se tem, nasce o desejar e amar as cousas a que se afeiçoa e inclina mais a sua natureza; amo isto porque me parece bem, e o que quero unir a mi polo que me quero, e desejo tudo o que me agrada e satisfaz, por meu respeito; e por isso chamaram ao amigo uma alma em dous corpos, e, como diz o provérbio, o amigo é outro eu; quero-lhe tudo o que para mi quero, e amo-o como a minha alma unida com a sua. $^{247}$

É pertinente, então, retomar o De Amore de Ficino, visto que essa concepção do amigo ou do amado como "um outro eu" é explicada de outra forma: "Amorem procreat similitudo" (De Amore, II, 8). É a semelhança que gera o amor, pois o amante esculpe no seu animus a figura do amado. Assim, o animus do amante torna-se espelho em que se reflete a imagem do amado; e é por isso que quando o amado se reconhece no amante, ele é compelido a também amá-lo. ${ }^{248}$ Portanto, amado transforma-se em amante e amante em amado, numa reunião amorosa de duas almas em um corpo, como naqueles conhecidos versos atribuídos a Camões: “Transforma-se o amador na cousa amada, / Por virtude do muito imaginar; / Não tenho, logo, mais que desejar, / Pois em mi[m] tenho a parte desejada. / Se nela está minha alma transformada, / Que mais deseja o corpo de alcançar? / Em si somente pode descansar, / Pois consigo tal alma está liada". 249

\footnotetext{
${ }^{246}$ Nesse sentido, vale lembrar as palavras de Aristóteles: "cada pessoa é a melhor amiga de si mesma e portanto deve amar-se mais a si mesma." (Ética a Nicômaco, IX, 8, 1168b).

${ }^{247}$ Lobo, F. R. Corte na Aldeia e Noites de Inverno. Prefácio e notas de Afonso Lopes Vieira. $2^{\mathrm{a}}$ ed. Lisboa: Sá da Costa, 1959, pp.130-131.

248 "Accedit quod amans amati figuram suo sculpit in animo. Fit itaque amantis animus speculum in quo amati relucet imago. Iccirco amatus cum in amante se recognoscat, amare illum compellitur." (De Amore, II, 8).

${ }^{249}$ Camões, L. de. Obra Completa, op.cit., p.301.
} 
A transformação amorosa é também um "paradoxo" termo empregado no romance Si penar es merecer, atribuído a Antônio Barbosa Bacelar, para designar os "prodígios" amorosos, tais como essa transfiguração das almas e um partir que é ficar e um morrer que é viver. Nesse sentido, as estâncias do romance que mais nos interessam, embora seja ele todo interessante, são as seguintes:

(...)

Quien ama vive en lo que ama,

Las Almas amor alterna,

Mal puede partirse una Alma,

Que es partirse de sí misma.

(...)

Oh que prodigio de Amor!

Oh paradoja suprema!

Muere Fábio, porque parte,

Y vive, porque se ausenta.

Muere en el partir por ver

Que en su ausencia Lises pena;

Vive en el partir, pues ve

Que su disgusto es fineza.

Si luego Fábio partiendo

Vive y muere, parte y queda,

Paradojas en Amor

Por méritos se veneram. ${ }^{251}$

Com base nesse poema, Mafalda Ferin Cunha faz observações muito relevantes sobre os antitéticos "discursos amorosos", não só da lírica dita de Bacelar, mas da lírica seiscentista em geral:

O romance "Si penar es merecer" (...) fornece uma síntese das antíteses que estruturam muitos destes discursos amorosos, liberdade / força, gostar / sentir, fineza / ofensa, presente / ausente, ficar / partir, viver / morrer, concluindo com uma conciliação de contrários, classificada

\footnotetext{
${ }^{250}$ Sobre os "paradoxos", afirma Gracián: "Son las Paradoxas monstros de la verdad, y vn extraordinario y más de Ingenio, alguna vez se recibe bien. En ocasiones grandes ha de ser el pensar grande." (Agudeza y Arte de Ingenio. Discurso XXIII ("De la Agudeza Paradoxa"), op.cit., p.148.

${ }^{251}$ Obras Poéticas de António Barbosa Bacelar, op.cit., pp.384-387.
} 
como prodígio, mas que se torna habitual nesta poesia: partir é ficar e morrer é viver. Paradoxos e oxímoros revelam o auge da confusão e do sofrimento dos amantes que albergam dilúvios de fogo no peito e incêndio de água nos olhos, choram pela boca e lamentam-se pelos olhos e comprovam engenhosamente que penar é gozar e, inversamente, ser feliz é motivo de desgosto (...). Por isso os apaixonados classificam como doce martírio o tormento que as amadas lhes impõem e experimentam tal contentamento na morte de amor que dela revivem para de novo poderem morrer (...).

Daí ser, ainda segundo a estudiosa, a imagem da fênix metáfora da "experiência do amante determinado a morrer e a viver pelo seu amor”, chegando-se, assim, à resolução da antítese vida / morte: "Os dois termos deixam de se excluir mutuamente, mas metamorfoseiam-se e enlaçam-se por meio de jogos de palavras que se repetem: o amante é cadáver vivo, a pena de amor é homicida e imortal, a morte é princípio de vida". 252

Já destacamos que essa morte e vida no amor pode ser compreendida como a conversão do amante no amado e, havendo reciprocidade, do amado no amante. Porém, pouco desenvolvemos a união amorosa. Visando esse propósito, é preciso, em princípio, diferenciar as opiniões de duas importantes autoridades que servem como balizas para as discussões quinhentistas e seiscentistas sobre o assunto; Martín José Ciordia resume tais opiniões da seguinte forma: o De Amore de Ficino sugere "una experiencia del amar donde el ayuntar está excluído. Tanto en su esfera especulativa como narrativa y poética, 'amor' y 'ayuntar' no sólo no se identifican sino que se oponen”; enquanto os Diálogos de Amor de Leão Hebreu sugerem "una experiencia del amar donde el ayuntar está incluído. Tanto en su esfera especulativa como narrativa y poética, 'amor' y 'ayuntar' no sólo no se oponen sino que por momentos se identifican". ${ }^{253}$

Sendo assim, os Diálogos de Leão Hebreu suscitam um aspecto do amor que não pode ser ignorado quando se trata da poesia seiscentista: a união física. Entre as definições de amor que encontramos nessa obra, afirma-se ser ele "desejo de fruir com união" ou "desejo de se converter por união na coisa amada"254 ou, ainda, "perene

\footnotetext{
${ }^{252}$ Idem, pp.24-25.

${ }^{253}$ Ciordia, M. J. Amar en el Renacimiento: un estudio sobre Ficino y Abravanel. Buenos Aires: Universidad de Buenos Aires, Facultad de Filosofia y Letras: Miño y Davila, 2004, p.235.

${ }^{254}$ Diálogos de Amor. Tradução de Giacinto Manuppella. Lisboa: Imprensa Nacional - Casa da Moeda, 2001, p.99.
} 
desejo de gozar com união a pessoa amada". ${ }^{255}$ Para que se configure um amor perfeito, portanto, é sempre necessária a união; mas esta não se restringe àquela espiritual das almas, sendo também essencial a física dos corpos, pois "estando as almas unidas em espiritual amor, os corpos desejam gozar a possível união, para que não fique nenhuma diversidade e a união seja em tudo perfeita; mormente porque, com a correspondência da união física, o amor espiritual aumenta e torna-se mais perfeito". ${ }^{256}$ Enfim, explica Fílon à sua amada Sofia em que consiste esse perfeito e verdadeiro amor, filho da razão e pai do desejo:

O perfeito e verdadeiro amor, como aquele que te consagro, é pai do desejo e filho da razão, e em mim o produziu a recta razão cognoscitiva. Porque, sabendo que havia em ti virtude, engenho e graça tão admiravelmente sedutoras como sobremaneira assombrosas, e desejando a minha vontade a tua pessoa, que a razão rectamente julga ser em tudo óptima, excelente e digna de ser amada, esta afeição e este amor me fizeram converter em ti, gerando em mim o desejo de que tu te convertas em mim, para que eu, amante, possa ser uma mesma pessoa contigo, amada, e em plena igualdade de amor forme de duas almas uma só, que possa de igual maneira vivificar e governar dois corpos. A sensualidade deste desejo faz nascer o apetite de outra espécie de união, a física, para que os corpos possam conseguir nela a possível união das almas que se compenetram reciprocamente. ${ }^{257}$

Posto que nascido da razão, o amor não se deixa governar por ela: “É com assombrosa veemência e incrível jeito que o verdadeiro amor violenta a razão e a pessoa amante; mais do que qualquer outro impedimento humano perturba a mente, que é sede do juízo". ${ }^{258}$ Por isso, violentada a razão, as palavras não podem explicar a causa do sofrimento amoroso, como se constata nestes versos da Fuente de Aganipe de Faria e Sousa, em que o poeta-amante, cego, está impossibilitado de escrever sobre a luz-amada que o cegou:

1. Amor me manda que escriba

\footnotetext{
255 Idem, p. 103.

${ }^{256}$ Idem, ibidem.

${ }^{257}$ Idem, p. 105.

${ }^{258}$ Idem, p. 107.
} 
Lo que estoy viendo en un Sol:

imagino que no sabe

lo que me manda el Amor.

2. Que no lo sabe imagino,

si sabe que ciego estoy

de una Luz, que apenas vista,

de vista me despojò.

3. Malicioso, pues, o necio

me incita a ser Escritor;

pues siendo ciego no ignora

si ven los que ciego son.

4. Mas como èl un ciego sea

con privilegio mayor

de ver màs quando es màs ciego,

pensarà que como èl soy.

5. Pero, si acaso lo piensa,

como puedo creer yo,

que ha de lograr un Humano

prerogativas de un Dios? ${ }^{259}$

Desprovido de razão (ou de vista), ao humano amante resta o desejo de união deleitável, já que a finalidade do amor "é o deleite do amante na coisa amada" ou, em outras palavras, a "união do amante com a coisa amada". ${ }^{260}$ Desse modo, só haverá amor enquanto houver esperança de lograr tal união, pois, como ensina Fílon a Sofia, é a esperança condição essencial do amor:

Concedo-te que nem Deus nem a Natureza põem numa criatura inteiro amor e desejo, ou seja, inclinação ou inerência, senão para conseguir ou para ser coisa possível, e não para o mero e evidente impossível. Por isso verás que um homem não deseja subir com seu pé ao céu ou voar com asas ou ser uma estrela ou segurá-la na mão, e quejandas coisas, as quais, embora sejam dignas e façam falta, e sejam reconhecidamente decorosas, nem por isso são desejadas, porque a sua impossibilidade é manifesta; e então, faltando a esperança de consegui-las, falta o desejo,

\footnotetext{
${ }^{259}$ Faria e Sousa, M. de. Fuente de Aganipe. Parte quinta, op.cit., fl.168.
}

${ }^{260}$ Hebreu, L. Diálogos de Amor, op.cit., p.392. 
pois a esperança de lograr a coisa que deleita, quando esta é conhecida e falta, espicaça o amor e o desejo de consegui-la, ao passo que, quando a esperança é frouxa, nunca o amor é intenso, nem o desejo é ardente; e quando é nula, por ser impossível a aquisição, anula-se também o amor e desejo de quem a conhece. ${ }^{261}$

Portanto, uma "esperança sem logro", como aquela que padece a persona lírica do soneto XVIII da Música do Parnaso de Botelho de Oliveira, é um impossível amoroso, uma "loucura" que, tratada com estilo agudo, intensifica a dor do amante que nunca pode alcançar a união com a coisa amada:

Se contra minha sorte enfim pelejo,

Que quereis, esperança magoada?

Se não vejo de Anarda o bem que agrada,

Não procureis o bem do que não vejo.

Quando frustrar-se o logro vos prevejo,

Sempre a ventura espero dilatada;

Não vejo o bem, não vejo a glória amada,

Mas que muito, se é cego o meu desejo?

Enfermais do temor, e não se alcança

$\mathrm{O}$ que sem cura quer vossa loucura;

E morrereis de vossa confiança.

Esperança não sois, porém se apura,

Que só nisto sereis certa esperança:

Em ser falsa esperança da ventura. ${ }^{262}$

Essa "esperança sem logro" é uma agudeza (ou conceito, visto que Gracián emprega, muitas vezes, esses dois termos como sinônimos) de improporción, que se forma "por artificio contrapuesto à la proporcion" e cuja perfeição decorre do fato de ser notada: "Nace de la proporcion la hermosura, no siempre de la improporcion en el hecho, pero el notarla en el concepto, es perfeccion". ${ }^{263}$ Correlacionam-se, assim, dois opostos: a esperança, que implica algo que sempre se espera lograr, e a ausência de

\footnotetext{
${ }^{261}$ Idem, p.314.

262 Oliveira, M. B. de. Poesia completa: Música do Parnasso, Lira Sacra, op.cit., pp.29-30.

${ }^{263}$ Gracián, B. Agudeza y Arte de Ingenio. Discurso V ("De la Agudeza de Improporcion, y disonancia"), op.cit., p.24.
} 
logro, que determina o adverso fim do esperar. Por isso, no referido soneto que desenvolve esse conceito, a esperança da persona lírica já nasce morta: o bem amoroso ou a glória amada que deseja de sua Anarda é, por definição, inalcançável.

Se nos Diálogos de Amor de Leão Hebreu, como já ressaltamos, uma viva esperança é condição indispensável para que se ame e se deseje, nesse poema de Botelho de Oliveira o amor e o desejo são frutos de uma esperança morta ou uma "falsa esperança da ventura". Contudo, em ambos, o que se almeja é a união com a coisa amada. Num outro soneto da Música do Parnaso (de seu "segundo coro", aquele das "rimas castelhanas"), reafirma-se essa ingrata condição do amor que, como o incorruptível cedro, "não floresce com o logro". Ademais, esclarece-se que o fim do amor é lograr o belo, isto é, o fruto que se deseja e que, logrado, desfloresce o desejar:

El cedro incorruptible, que eminente

Apuesta eternidades con los años,

Formando al Cielo de altivez engaños,

Si nunca logra el fruto, es floreciente.

Pero si el fruto logra dulcemente

Para dar a los logros desengaños,

Con los esquivos, si fecundos daños

Nunca galán de flores si consiente.

El amor a los años incorrupto

No ha de lograr lo bello, que se ofrece,

Aunque lo juzgue amor dulce tributo,

Al fruto de lo hermoso, que apetece;

Si florece el Amor, no logra el fruto,

Si el Amor logra el fruto, no florece. ${ }^{264}$

O amor incorrupto não pode atingir seu fim, que é o deleite do amante em sua amada, ou melhor, a união do amante com a beleza amada. Isso porque, o amor é como o cedro, mas enquanto este ou frutifica ou floresce, aquele ou floresce ou obtém seu fruto.

Essa paradoxal condição do amor humano pode ser compreendida na sua origem, quando os primeiros amantes cometeram o primeiro pecado ao comerem o fruto da árvore proibida da ciência do bem e do mal, segundo a interpretação que Leão

${ }^{264}$ Oliveira, M. B. de. Poesia completa: Música do Parnasso, Lira Sacra, op.cit., p.156. 
Hebreu apresenta da "sagrada história" de Adão e Eva. Desse modo, no último dos Diálogos de Amor, ao instruir Sofia sobre o nascimento e os progenitores do amor, Fílon explica que a "fábula" do andrógino referida por Platão no Banquete foi, na verdade, "transmitida por um autor mais antigo do que os Gregos, isto é, da sagrada história de Moisés acerca da criação dos primeiros pais humanos, Adão e Eva". ${ }^{265}$ Portanto, teria Platão imitado Moisés:

Quer dizer que Adão, isto é, o «homem primeiro» que Deus criou no sexto dia da criação, por ser um suposto humano continha em si macho e fêmea sem separação, e por esse motivo diz que «Deus criou Adão conforme a imagem de Deus, criou-os macho e fêmea»: chama-lhe uma vez no singular (Adão, um homem), outra vez no plural («criou-os macho e fêmea»), para denotar que, sendo um suposto, continha macho e fêmea juntos. (...) Platão e os gregos tomaram daí aquele antigo andrógino, meio-macho e meio-fêmea. ${ }^{266}$

No entanto, o amor só nasceu quando Deus, estando Adão adormecido, pegou num dos seus "lados" 267 , naquele que era feminino, e separou-o criando a mulher, Eva. Depois de formada esta, Deus apresentou-a ao já desperto Adão, que a vendo disse:

«Agora sim, este é osso dos meus ossos e carne da minha carne; esta chamar-se-á virago, porque foi extraída do homem». E continua dizendo: «Por isso o homem deixará o pai e a mãe, juntar-se-á com sua mulher e serão carnalmente só um», no sentido que o homem e a mulher, visto resultarem da cisão dum mesmo indivíduo, pelo matrimónio e pelo coito voltam a reintegrar-se num mesmo suposto carnal e individual. Daqui tomou Platão a divisão do andrógino em dois meios separados, macho e fêmea, e o nascimento do amor, que é a inclinação que fica a cada uma das metades para se reintegrar com o seu complemento e readquirir a unidade carnal. ${ }^{268}$

\footnotetext{
${ }^{265}$ Diálogos de Amor, op.cit., p.325.

${ }^{266}$ Idem, p.328.

${ }^{267}$ Ensina Fílon a Sofia que "lado", na língua hebraica, é vocábulo equivalente a "costela", mas que neste e em outros trechos do texto sagrado o que está propriamente escrito é "lado".

${ }^{268}$ Idem, p.329.
} 
Assim separados, homem e mulher estavam, então, suscetíveis ao primeiro pecado. Enganada pela serpente, que representa, de acordo com Leão Hebreu, o apetite carnal, "a mulher causou o pecado do marido e o seu, comendo da árvore proibida da ciência do bem e do mal, que é a deleitação carnal, aparentemente boa no princípio e, com a continuação, funesta no fim, porque desvia o homem da vida eterna e o torna mortal". ${ }^{269}$ Daí se infere que a finalidade propriamente humana não é gerar, mas se beatificar na contemplação divina no Paraíso; a geração é um remédio para a mortalidade decorrente do pecado.

Dessa maneira, o "fruto" que o amor não pode lograr, como lemos naquele soneto castelhano da Música do Parnaso, pode ser compreendido como essa "deleitação carnal" que afasta o homem de seu verdadeiro propósito, o contemplativo. Provar desse fruto é incorrer no pecado, por deixar-se conduzir, unicamente, pelo apetite carnal, expondo, enfim, a mortalidade humana e, consequentemente, a fugacidade desse corrupto amor sensual. Por isso, esse amor sem logro, ou melhor, sem fruto é também ensinamento, da mesma forma que o sentido alegórico da "autêntica história moisaica" de Adão e Eva é proveitoso para Sofia:

Estas coisas, que com efeito aconteceram materialmente ao primeiro homem, alegoricamente representam a vida e os sucessos de cada um dos homens, qual seja o seu fim bem-aventurado, o que requer a necessidade da humanidade, o que se segue a um pecado excessivo e o castigo daquela ocorrência, com a derradeira possibilidade de remediar. Se o entenderes cabalmente, verás num espelho a vida de todos os homens, o bem e o mal deles, conhecerás o caminho do qual se deve fugir e o que se deve seguir para alcançar a eterna bem-aventurança onde nunca se morre. ${ }^{270}$

O amor que se guia apenas pelo apetite carnal é fruto do pecado e, portanto, perecível, devendo sempre sofrer o amante os virtuosos desdéns da amada. A contenda desse amor do gosto contra os desdéns ou as virtudes da amada é uma "pendência" amorosa que D. Francisco Manuel de Melo descreve no madrigal XXXIV ("Pendencia de Amor") da Tiorba de Plymnia, a "terceira musa" de suas Obras Métricas:

\footnotetext{
${ }^{269}$ Idem, p.331.

${ }^{270}$ Idem, pp.337-338.
} 
Salió anoche el Amor, por darse gusto,

de valentón, al barrio del Contento;

y al llamar a la puerta a una Esperanza,

cátale aquí, le alcanza

un cierto bravo que le llaman Susto,

con otro que le llaman Escarmiento;

tiró el Susto un tormento,

repara Amor en el broquel del brío,

entróse a componellos un Desvío;

mas cuando se templaban sus vaivenes,

llegan cuatro Desdenes,

saca Amor por espada la paciencia,

ríñese la pendencia,

y al pelear gallardo, airoso y recio,

traspásale la punta de un Desprecio.

Conoce Amor su herida,

teme perder la vida;

ya le asaltan las ansias de las dudas;

llámate: no le ayudas.

¿Mas cómo acudirás a sus clamores,

si andas tú con los mesmos matadores? $?^{271}$

Esse madrigal personifica o amor e seus inimigos. Nesse sentido, é importante lembrar como se define a prosopopeia ou personificação nas retóricas antigas; na Rhetorica ad Herennium, por exemplo, ela é chamada de conformatio e está situada entre os "ornamentos de sentenças" (sententiarum exornationes): "Conformatio est, cum aliqua, quae non adest, persona confingitur quasi adsit, aut cum res muta aut informis fit eloquens, et forma ei et oratio adtribuitur ad dignitatem adcommodata, aut actio quaedam" (Rhetorica ad Herennium, IV, 66). ${ }^{272}$ À segunda parte dessa definição é que convêm aquelas personificações do mencionado poema de D. Francisco Manuel de Melo, pois o amor e os desdéns, coisas informes, praticam ações adequadas às suas respectivas dignidades: um busca satisfazer o gosto e os outros defendem o bem da

\footnotetext{
${ }^{271}$ Melo, F. M. de. La Tiorba de Plymnia. In: Obras Métricas. Volume I. Edição coordenada por Maria Lucília Gonçalves Pires e José Adriano de Freitas Carvalho. Braga: Edições APPACDM, 2006, p.304.

272 "A personificação consiste em configurar uma pessoa ausente como se estivesse presente, também em fazer falar uma coisa muda ou informe atribuindo-lhe ou forma e discurso ou uma ação adequados a sua dignidade" (Retórica a Herênio, op.cit., p.307).
} 
amada. Como ensina Quintiliano, esse fingir a forma das coisas que não a têm - um dos ofícios da prosopopeia, descrita entre as "figuras de sentenças" (figurae sententiarum) é ficção (fictio) muito usada pelas autoridades poéticas, como o fez Virgílio com a Fama e Ênio com a Morte e com a Vida, as quais introduz altercando numa sátira. ${ }^{273}$

$\mathrm{O}$ amor assim personificado sai, guiado pelo apetite, à procura de seu contentamento, com a esperança de alcançar o deleite desejado, mas só encontra susto e escarmento. Ainda que prevenido pelo tormento e escarmentado, o amor insiste em sua busca, deparando-se com poderosos inimigos: os quatro desdéns. Nesse duelo, fica o amor mortalmente ferido e não pode recorrer à sua amada, pois é nela própria que se acham aqueles matadores desdéns. Não se esclarece por que são estes, especificamente, quatro, porém se pode presumir que representam as quatro virtudes cardinais que protegem a amada, bela e virtuosa, visto que sua beleza é também bondade. Assim, o desejo, atraído pela beleza, tem que enfrentar a prudência, a justiça, a fortaleza e a temperança da amada que, protegida, não cede jamais a viciosos clamores.

Essa batalha entre o amor-paixão, ${ }^{274}$ que almeja "dar-se gosto", e as virtudes que defendem o bem amado pode ser desenvolvida no campo da doutrina estoico-cristã dos séculos XVI e XVII, no qual é justamente D. Francisco Manuel de Melo um dos principais contendores. Tal "doutrina estoico-cristã" refere-se às discussões quinhentistas e seiscentistas sobre a filosofia estoica, empreendidas por autores como Justo Lípsio, Francisco de Quevedo e o próprio D. Francisco Manuel, que resultaram em ensinamentos estoico-cristãos ${ }^{275}$ e que os estudiosos, desde o trabalho pioneiro de Léontine Zanta, ${ }^{276}$ costumam chamar de "neoestoicismo". 277

\footnotetext{
273 "Sed formas quoque fingimus saepe, ut Famam Vergilius, ut Voluptatem ac Virtutem, quem ad modum a Xenophonte traditur, Prodicus, ut Mortem ac Vitam, quas contendentes in satura tradit, Ennius." (Inst. Orat., IX, 2, 36).

${ }^{274}$ Utilizamos o termo "paixão" na acepção predominante da época, como uma "perturbação", tanto do corpo como da alma. No Vocabulário de Bluteau, a palavra é assim definida: "Movimento do appetite fenfitivo, occafionado da imaginação de hum bem, ou de hum mal apparente, ou verdadeyro, que perturba o eftado interior, \& exterior do homem, \& lhe tira a fua tranquilidade natural. (...) Na opinião dos Eftoicos a felicidade do homem eftá em não ter payxão algũa (...). Paixão defordenada, violenta, cega, contraria à razão. Animi perturbatio (...). Moderar, reprimir, domar as paixões. Ser fenhor das fuas paixões" (Vocabulario Portuguez, \& Latino, op.cit., volume 6, verb. "paixão", pp.188-189).

${ }^{275}$ Fizemos uma longa análise (à qual recorreremos diversas vezes) sobre as repercussões da filosofia estoica nos séculos XVI e XVII em nossa dissertação de mestrado, intitulada Narração e doutrina na Constante Florinda: exempla estóicos para a vida cristã (São Paulo: Universidade de São Paulo, 2008), especialmente no terceiro capítulo ("Filosofia estóica nos séculos XVI e XVII: uma doutrina estóicocristã"). Nesse texto, encontra-se uma detalhada bibliografia acerca da questão.

${ }^{276}$ Zanta, L. La Renaissance du Stö̈cisme au XVI siècle. Thèse pour le Doctorat ès Lettres, présentée à la Faculté des Lettres de l'Unversité de Paris. Paris: Honoré Champion, 1914.

${ }^{277}$ As nossas restrições ao emprego desse termo, "neoestoicismo", estão devidamente expostas na nossa dissertação de mestrado (Narração e doutrina na Constante Florinda: exempla estóicos para a vida cristã, op.cit., pp.106 e ss.) e não convém reproduzi-las aqui. Todavia, é pertinente citar alguns estudos
} 
Antes, no entanto, é importante destacar os assuntos centrais que foram discutidos na ética da antiga Stoa, pois a partir deles se evidenciarão outros aspectos, já mesclados à doutrina cristã, do agudo e variado amor da lírica seiscentista. Desse modo, uma fonte fundamental para se compreender de que tratava a moral estoica antiga é o livro VII das Vidas de Diógenes Laércio. ${ }^{278}$ Segundo este, então, os filósofos da Stoa dividiram a ética em doutrinas do impulso, do bem e do mal, das paixões, da excelência, do fim supremo, do valor mais alto, dos deveres e da exortação e dissuasão em face da ação (Vidas, VII, 84). O primeiro impulso (hormé) do homem é o da sobrevivência, e não em direção ao prazer, como afirmavam os epicuristas. Nos animais, à diferença das plantas, há um impulso que os fazem seguir seus próprios fins. Portanto, “já que os seres racionais receberam a razão com vistas a uma conduta mais perfeita, sua vida segundo a razão coincide exatamente com a existência segundo a natureza, enquanto a razão se agrega a eles como aperfeiçoadora do impulso" (Idem, VII, 86). Essa é, em linhas gerais, uma das noções estoicas que mais suscitará discussões: o secundum naturam niuere. ${ }^{279}$

Outra concepção muito relevante para a doutrina estoica, a virtude ou excelência (areté), foi definida por Crisipo como uma disposição da psyché "harmoniosamente equilibrada, digna de ser escolhida em si e por si, e não por qualquer temor, ou esperança, ou impulso exterior". E a felicidade consistiria justamente na virtude, pois esta é "como uma alma que tende a tornar toda a vida harmoniosa" (Idem, VII, 89), sendo quatro as virtudes primárias ou principais: a prudência (phronesis), a coragem (andreia), a justiça (dikaiosyne) e a temperança (sophrosyne). Logo, há

que discutem esse chamado "neoestoicismo": Saunders, J.L. Justus Lipsius: The Philosophy of Renaissance Stoicism. New York: The Liberal Arts Press, 1955; Ettinghausen, H. Francisco de Quevedo and the Neostoic Movement. Oxford: Oxford University Press, 1972; Spanneut, M. Permanence du stöicisme de Zenon à Malraux. Bruxelles-Paris: Duculot, 1973; Oestreiche, G. Neostoicism and the Early Modern State. Cambridge: Cambridge University Press, 1982; Blüher, K. A. Séneca en España: investigaciones sobre la recepción de Séneca en España desde el siglo XIII hasta el siglo XVII. Versión española de Juan Conde. Edición corregida y aumentada. Madrid: Gredos, 1983; Morford, M. Stoics and Neostoics. Rubens and the Circle of Lipsius. Princeton: Princeton University Press, 1991; Lagrée, J. Juste Lipse et la Restauration du Stoïcisme. Paris: J. Vrin, 1994; Le stö̈cisme au XVI et au XVII siècle: Le retour des philosophies antiques à l'âge classique. Tome I. Sous la direction de Pierre-François Moreau. Paris: Albin Michel, 1999; Carabin, D. Les idées stö̈ciennes dans la littérature morale des XVI et XVII siècles (1575-1642). Paris: Champion, 2004; e Stö̈cisme et Christianisme à la Renaissance, Cahiers V.L. Saulnier 23. Reponsable Catherine Magnien. Paris: Rue d'Ulm/Presses de l'École normale supérieure, 2006.

${ }^{278}$ Utilizamos a seguinte edição: Vidas e Doutrinas dos Filósofos Ilustres. Tradução do grego, introdução e notas de Mário da Gama Kury. $2^{a}$ ed. Brasília: UnB, 1977. Vale ressaltar, porém, que outra excelente fonte antiga sobre a moral estoica é o livro III do De finibus de Cícero.

${ }^{279}$ Sêneca, por exemplo, afirma que viver feliz é viver segundo a natureza: "Idem est ergo beate uiuere et secundum naturam" (De Vita Beata, VIII, 2). 
também quatro vícios primários: a imprudência, a covardia, a injustiça e a intemperança, sendo o vício (kakia) definido como "a ignorância das coisas cujo conhecimento constitui a excelência" (Idem, VII, 93).

Depois das virtudes, Diógenes Laércio passa a expor a noção estoica de bem. De acordo com ele, para os estoicos, o bem é o útil ou, ainda, a "perfeição natural de um ser racional enquanto racional" (Idem, VII, 94). E o bem perfeito é o belo, "porque está repleto de todos os fatores requeridos pela natureza, ou porque tem proporções perfeitas" (Idem, VII, 100). Todos os bens são iguais e nenhum pode ser aumentado ou diminuído. Das coisas que existem, algumas são boas e outras são más, e outras não são nem boas nem más. Estas últimas são "indiferentes" (adiaphora), pois não contribuem nem para a felicidade nem para a infelicidade, assim como não provocam nem atração nem aversão. ${ }^{280}$ Mas mesmo entre as indiferentes, algumas coisas merecem ser escolhidas e outras rejeitadas, dependendo de seu "valor". ${ }^{281}$

Por fim, não poderíamos deixar de mencionar como Diógenes Laércio resume a doutrina estoica das "paixões" (pathé), ${ }^{282}$ uma questão que, em última instância, passou a ser confundida, muitas vezes, com a própria filosofia estoica. Assim, o pathos, conforme teria ensinado Zenon, é um movimento da psyché, "irracional e contrário à natureza, ou um impulso excessivo" (Idem, VII, 110). As principais paixões, das quais derivam as outras, são a dor, o medo, a concupiscência e o prazer. E tais pathé são enfermidades ou doenças da psyché, como aquelas que atingem o corpo. ${ }^{283}$ Entretanto, algumas "disposições passionais" são boas - a alegria, a cautela e a vontade - e opõemse àquelas paixões doentias.

Dessa maneira, o sábio estoico é aquele que está "imune às paixões porque não pode cair diante delas", ou seja, nele quem domina é a apatheia. É curioso notar que tal palavra, que causará tanta discussão (e será tão criticada) entre os autores que buscam

\footnotetext{
${ }^{280}$ Com relação aos "indiferentes" (adiaphora) na filosofia estoica antiga, vejam-se os Stoicorum Veterum Fragmenta, I, 191 e ss.; II, 177 e ss. (Arnim, H. F. A. Stoicorum Veterum Fragmenta. 4v. Lipsiae: in aedibus B.G. Teubneri, 1903-24).

281 “Eles entendem por 'valor' uma certa contribuição à vida equilibrada pela razão, requisito de todo bem; mas, entendem também uma certa potência ou utilidade mediata que contribui para a vida segundo a natureza, como a contribuição que a saúde e a riqueza trazem à vida segundo a natureza" (Vidas, VII, 105).

${ }^{282}$ Além de Diógenes Laércio, talvez a principal fonte antiga para se compreender o pathos estoico sejam as Tusculanae Disputationes de Cícero, em especial, os livros III e IV.

283 “A enfermidade da alma é uma afecção ligada à debilidade, e consiste em imaginar que uma coisa é fortemente desejável, quando na realidade não é" (Vidas, VII, 115). Ver também as Tusculanae Disputationes, III, IV-V, 8-10; particularmente, o seguinte trecho: "Ita fit ut sapientia sanitas sit animi, insipientia autem quasi insanitas quaedam, quae est insania eademque dementia" (Tusculanae Disputationes, III, V, 10).
} 
coadunar a doutrina estoica com a cristã, já carrega consigo, desde Diógenes Laércio, um sentido negativo: "o termo 'apatia', que designa propriamente a ausência de paixões, pode aplicar-se também ao homem mau, no sentido de que ele é insensível e não se deixa comover" (Idem, VII, 117). Outra questão bastante delicada para os estoicocristãos é aquela dos sábios considerados como deuses (para os cristãos, rivais de Deus): "Os sábios são criaturas divinas, pois têm em si, por assim dizer, a divindade" (Idem, VII, 119). Ademais, para a Stoa antiga, somente o sábio é livre e capacitado para governar, julgar e discursar, enquanto o néscio ou estulto é sempre servo. Por isso, a amizade só existe entre sábios, pois apenas eles são homens bons. Assim como todos os bens são iguais e não podem ser divididos, todas as virtudes também o são, e quem possuir uma, possuirá todas. Não há meio termo, como queriam os peripatéticos: ou se é virtuoso ou se é vicioso (Idem, VII, 127).

Portanto, aquela "pendência" entre o amor do gosto e os quatro virtuosos desdéns da amada, descrita no citado madrigal de D. Francisco Manuel de Melo, pode ser mais bem compreendida tendo em vista a ética estoica. As quatro virtudes primárias defendem a areté da amada de uma das principais e também mais perniciosas paixões: a concupiscência, que é uma grave enfermidade da psyché. Contudo, esses ensinamentos estoicos devem ser mesclados à doutrina cristã, já que nessa querela amorosa são de suma importância as noções de pecado, culpa e castigo, como se evidencia num outro poema amoroso do Melodino, o soneto XVII ("Porfia infelice") da Tuba de Calíope, a "quarta musa" de suas Obras Métricas:

Qual, Senhora, é dos dous nesta querela o mais culpado, foi contenda antiga: vós, que tanto me dais que dela diga? Eu, que não posso já senão dizê-la?

Vós, que ma repartis, podeis detê-la, mandando-lhe que pare e não me siga. $\mathrm{Eu}$, que a padeço, quando mais amiga, assaz de pouco faço em padecê-la.

Até nas próprias queixas meu destino quer que, a vosso desprezo obediente, quando dele me queixe o aclame dino.

Pois deixai-me queixar; cuidará a gente, não que me desprezais como mofino, 
mas que me castigais por delinquente. ${ }^{284}$

$\mathrm{Na}$ querela do amor, a culpa do delinquente amante é castigada pelo digno desprezo da amada; mais uma vez, há uma batalha entre a paixão amante e a virtude amada. Luta essa que se desenvolve num estilo antitético que, ao aproximar conceitos extremos, exprime a porfia infeliz, castigo justo para um amor criminoso cujo agir não segue a razão: por isso, a persona lírica (amante), obedecendo, irracional ou apaixonadamente, ao desprezo da amada, queixa-se dele para aclamá-lo digno. Porém, no terceto final, essas contradições se resolvem: esse justo desprezo da amada é punição, autorizada pela "gente", para o infeliz e delinquente desejo-amante, que insiste em alcançar o que é indigno.

Tanto neste soneto quanto naquele madrigal, a doutrina estoico-cristã parece ser uma importante fonte para a concepção amorosa que neles se observa, o que se pode comprovar pelos escritos doutrinários do próprio D. Francisco Manuel de Melo, nos quais se encontram diversas discussões sobre os ensinamentos estoicos ou que deles dependem. Segismundo Spina ${ }^{285}$ e Maria Lucília Gonçalves Pires ${ }^{286}$ já indicaram a presença marcante da filosofia estoica (em particular, de Sêneca ${ }^{287}$ ) nas obras de D. Francisco Manuel e, mais do que isso, a necessidade de estudos que tratem detidamente da questão. ${ }^{288}$ Entretanto, está fora das pretensões e possibilidades deste nosso trabalho

\footnotetext{
${ }^{284}$ Melo, F. M. de. A Tuba de Calíope. In: Obras Métricas, op.cit., volume II, p.455. Vale lembrar também a edição de Segismundo Spina: A Tuba de Calíope: quarta musa das Obras Métricas. Introdução, estabelecimento do texto, notas e glossário por Segismundo Spina. São Paulo: Brasiliense; Edusp, 1988, p.100.

285 "Sêneca foi uma presença constante na poesia do Melodino, como foi nos poetas, nos moralistas e dramaturgos da Europa do século XVII - especialmente na Península Ibérica." Por isso, conclui Spina: "Urge, pois, que a influência de Sêneca na cultura portuguesa dos séculos XVI e XVII seja traçada, pois do contrário as tentativas da história geral da cultura lusa estão fadadas ao insucesso quando saímos do Renascimento" (A tuba de Calíope: quarta musa das Obras Métricas, op.cit., pp.32 e 34).

286 "Da presença da filosofia estóica em geral e senequista em particular na obra de D. Francisco Manuel de Melo nenhum autor, que eu saiba, se ocupou detidamente, se bem que a questão tenha sido por vezes apontada" "OO tema da "guerra interior» nas Obras Métricas de D. Francisco Manuel de Melo". In: Xadrez de Palavras: Estudos de Literatura Barroca. Lisboa: Cosmos, 1996, p.64).

${ }^{287}$ Acerca da recepção de Sêneca no século XVII, é importante ressaltar que suas obras contavam com a "monumental" (segundo Blüher) edição de Lípsio (Antuérpia, 1605): "el punto culminante de esta actividad editora, que se desarrolló con extrema rapidez en el espacio de dos décadas desde 1585, lo constituyó la edición monumental, con comentarios filosóficos, de Lipsio (Amberes, 1605 y ed. posteriores), que llegó a ser la edición más importante del siglo XVII.” (Blüher, K. A. Séneca en España, op.cit., p.418). A respeito das edições de Sêneca a partir de 1585 e de suas traduções castelhanas, vejamse as informações do mesmo Blüher (Idem, pp.418-426).

${ }^{288}$ Vale lembrar que, além de Segismundo Spina e Maria Lucília Gonçalves Pires, outros pesquisadores abordaram, ainda que muito superficialmente, a doutrina estoica na obra de D. Francisco Manuel: Manuppella, G. "Acerca do Cosmopolitismo Intelectual de D. Francisco Manuel de Melo" (In: Brasília, volume XI, Coimbra, 1961, pp.59-76); Carvalho, J. A. de. "A poesia sacra de D. Francisco Manuel de Melo" (In: Arquivos do Centro Cultural Português, volume VIII. Paris: Fundação Calouste Gulbenkian,
} 
fazer uma análise exaustiva desse tema. O que faremos é expor algumas discussões que dialogam com a Stoa e que possibilitam uma melhor compreensão da noção de amor que verificamos naqueles mencionados poemas do Melodino; debates esses presentes, especificamente, em dois textos das Obras Morales do autor: El Fenis de Africa: Agustino Aurelio, Obispo Hypponense (1648-1649) e Vitoria del Hombre sobre el Combate de Virtudes y Vícios: Triunfo de la Filosofia Cristiana contra la Doctrina Estoyca (publicada, possivelmente, depois de março de 1650). ${ }^{289}$

Antes, no entanto, é interessante recordar que num de seus Apólogos Dialogais, o Hospital das Letras, além do próprio D. Francisco Manuel e de Trajano Boccalini, os outros dois personagens que participam do diálogo são justamente Justo Lípsio e Francisco de Quevedo, ou seja, dois dos principais defensores da doutrina estoico-cristã nos séculos XVI e XVII. Quevedo, aliás, com quem D. Francisco Manuel de Melo teve relações próximas, ${ }^{290}$ e que, além de se declarar um estudioso e apreciador da filosofia estoica, afirmou que ela serviria como guia em momentos difíceis de sua vida: "Yo no tengo suficiencia de estoico, mas tengo afición a los estoicos. Hame asistido su doctrina por guía en las dudas, por consuelo en los trabajos, por defensa en las persecuciones, que tanta parte han poseído de mi vida. Yo he tenido su doctrina por estudio continuo; no sé si ella ha tenido en mí buen estudiante". ${ }^{291}$

Isso posto, é preciso, então, destacar algumas discussões daqueles escritos das Obras Morales de D. Francisco Manuel que podem mostrar outras faces do diversificado amor da lírica seiscentista. Dessa forma, no Fenis de Africa, há a noção da "interior batalha" entre a razão e as paixões, que leva à crítica da apatheia estoica. Maria Lucília Gonçalves Pires assim sintetiza a questão:

D. Francisco, dissertando sobre a «interior batalha» que se trava no homem entre a razão e as paixões, (Parte I, Livro I, Acção 26), refuta a doutrina estóica, contrapondo-lhe Platão e Aristóteles. Segundo o autor,

1974, pp. 295-404). Além disso, há o "Posfácio" de Adma Muhana, em sua edição dos Infortúnios trágicos da constante Florinda (São Paulo: Globo, 2006, pp.327-375), no qual é feita uma abordagem muito mais completa da doutrina estoico-cristã, não só de D. Francisco Manuel, mas dos séculos XVI e XVII em geral.

289 Os dois textos fazem parte do primeiro tomo das Obras Morales de Don Francisco Manuel a la Serenissima Catalina Reyna de la Gran Bretaña (En Roma: Por el Falco, 1664). Nossas citações serão feitas sempre com base nessa edição.

290 Acerca das relações entre D. Francisco Manuel de Melo e Quevedo, veja-se: Colomès, J. "Sur les relations de D. Francisco Manuel de Melo avec Quevedo". In: Arquivos do Centro Cultural Português, vol. II, 1970, pp.573-577.

${ }^{291}$ Quevedo, F. de. Nombre, origen, intento, recomendación y descendencia de la doctrina estoica (1634). In: Obras Completas. Tomo I: Obras en prosa. $6^{\mathrm{a} e d . ~ M a d r i d: ~ A g u i l a r, ~ 1992, ~ p .1093 . ~}$ 
estes filósofos consideram as paixões inseparáveis da natureza humana e afirmam ser a atitude do sábio, não aniquila-las, mas sim controlá-las. E a proposta estóica de inalterável tranquilidade espiritual suscita mesmo a D. Francisco um comentário um tanto céptico: «Esta fue siempre la más oída y menos vista filosofia de quantas el mundo ha profesado». ${ }^{292}$

Nessa apreciação da autora, nota-se certo desconhecimento da recepção da filosofia estoica em fins do século XVI, sendo equivocado afirmar, simplesmente, que há uma rejeição da doutrina estoica por pretender-se moderar a apatheia; isso porque, é exatamente essa uma das principais características da doutrina estoico-cristã dos séculos XVI e XVII. E a citação que se faz do texto de D. Francisco ("Esta fue siempre la más oída y menos vista filosofia de quantas el mundo ha profesado"), avaliada como "um comentário um tanto céptico", nada mais é do que a reprodução de uma antiga e conhecida crítica à ética estoica, divulgada, pelo menos, desde Cícero e Tácito.

Desse modo, vale a pena nos determos um pouco na acción XXVI da primeira parte do livro I do Fenis de Africa, por ser um dos momentos da obra em que o diálogo crítico com a filosofia estoica se mostra mais evidente. Entretanto, isso não implica um "antiestoicismo" de D. Francisco Manuel, como supõem Maria Lucília Gonçalves Pires (como vimos no trecho acima citado) e Giacinto Manuppella (sendo que o foco das análises de Manuppella é a Vitoria del Hombre, embora também faça comentários sobre El Fenis de Africa, como veremos mais adiante).

O assunto dessa acción XXVI é a "dura batalla" dos "effetos" e dos "affectos". Estes últimos são os "mouimientos, ó passiones, proprias del animo"; aqueles são "las execuciones del entendimiento"; e, por isso, seriam "cosas entre sy contrarias". 293 Segundo D. Francisco Manuel, esse tema diz respeito à filosofia moral, e, entre os gregos, as commociones da alma foram divididas em duas partes: Pathi e Eupathi, sendo ambos os termos derivados de Pathia que, "en romance, es: Padecimiento". Já os latinos chamaram a essas mesmas "comoções": "Passiones, y Constancias". Para abordar a questão, o autor, como ele mesmo declara, fará uso das concepções das escolas platônica, peripatética e estoica. Porém, aos platônicos e peripatéticos, opunham-se os estoicos, que queriam saber: "si a los pechos de los sabios eran comunes

\footnotetext{
292 “O tema da «guerra interior» nas Obras Métricas de D. Francisco Manuel de Melo”, op.cit., pp.66-67.

${ }^{293}$ El Fenis de Africa, Parte I, Livro I, Ação 26, p.201.
} 
los affectos, que a los demás hombres?"294 Para Zenon e Crisipo, “cabeça dos estoicos", a resposta seria negativa. Cícero é que teria tentado conciliar essas escolas explicando que a divergência não estava na coisa, mas apenas no nome: a ética estoica teria estreitado a noção do bem, identificando-o somente à virtude. E é dessa diversa opinião que procedeu o "certamen de toda la filosofia: En, si era licito, ó ilícito al sabio, sentirse, ó no sentirse, con la perdida de los bienes; dando por este modo a entender los prosperos, ó aduersos casos, al sapiente sucedidos". ${ }^{295}$ Os peripatéticos almejam alguma sujeição dos affectos à sabedoria, mas nunca seu rendimiento completo, como querem os estoicos. Para estes filósofos, de acordo com o autor, o sábio é aquele que, por um hábito vitorioso, alcança o império sobre os "casos", que torna inalterável o ânimo do virtuoso. Em meio a discussões como essa é que surge a afirmação, como querem alguns, "antiestoica": "Esta fue la más oída, y menos vista, filosofia, de quantas el mundo ha profesado". Do outro lado, estão os platônicos e peripatéticos, para quem "el afligir con las aduersidades, es mayor indicio de sabiduria, y de bondad, que el despreciallas". 296

Para D. Francisco Manuel, tal disputa entre os "Éticos" (aqueles que tratam da filosofia moral) se resolve, sem contenda, entre os "Naturais" (aqueles que se dedicam à "Física", pensando-se na antiga tripartição da filosofia): "porque aquellas visiones del alma, que llaman fantasias, no està en nuestro albedrio que acontezcan, ó dexen de acontecer al alma, horriblemente, quando vienen de cosas horribles, ó apaciblemente, quando de cosas apacibles proceden". ${ }^{297}$ Então, é necessário que essas paixões (as fantasias) perturbem ou alegrem, pois elas se antecipam às operações do juízo, que é quem divide a contenda de affectos e de effetos. Os fantasmas, como diz o autor, não causam por si, sem a intervenção do entendimento, a opinião de mal ou de bem; nem são reprovados ou aceitos antes de julgados. Embora não citada no texto, essa discussão remete a uma das noções mais importantes e recorrentes em Epicteto, que é a distinção entre aquilo que está sob nosso controle e aquilo que não está. O que o homem controla é apenas sua prohairesis, seu "propósito moral" ou sua capacidade de antecipação e escolha prévia, que o leva, ou deveria levar, a fazer um uso correto das phantasias. ${ }^{298} \mathrm{Já}$ para D. Francisco Manuel, trata-se do juízo: "la potestad de la sabidoria; y es virtud la

\footnotetext{
${ }^{294}$ Idem, ibidem, p. 202.

${ }^{295}$ Idem, ibidem, p. 203.

${ }^{296}$ Idem, ibidem, p. 204.

${ }^{297}$ Idem, ibidem, p. 205.

${ }^{298}$ Ver, por exemplo, Diatribes, I, 1; e Encheiridon, 1.
} 
sentencia desta potestad, por la qual se diuede lo bueno, de lo malo". ${ }^{299}$ E, segundo os estoicos, seria essa a única diferença entre o ânimo do néscio e o do sábio: o ânimo do primeiro se rende às paixões, superando com os affectos aos effetos; enquanto que o do sábio, ainda que padeça, necessariamente, as paixões, guarda na sua vontade um estável conhecimento do que deve obrar, e dessa complacência nasce o vigor com que obra. Conclui, então, o autor: "Por esto, quiçá, dixeron los Estoycos: No tiene el sabio passiones; porque nunca le vieron a ellas rendido; no porque inorassen, no està en nuestra mano el escusar ser dellas combatido". 300

Como se nota, tais colocações de D. Francisco Manuel de Melo não indicam um ceticismo em relação à doutrina estoica, como supôs Maria Lucília Gonçalves Pires. Ao contrário, o debate que há nesse trecho d'El Fenis de Africa mostra como a "escola estoica" é uma das mais importantes fontes para os autores do século XVII, quando o assunto abordado diz respeito à filosofia moral. Ao se discutir as paixões, por exemplo, os estoicos são auctoritates quase sempre imprescindíveis. As doutrinas antigas, seja a platônica, a peripatética ou a estoica, não podem ser simplesmente refutadas por esses autores quinhentistas e seiscentistas; elas fazem parte da própria constituição da "filosofia cristã", ${ }^{301}$ que é aquela que quase todos eles aprovam e defendem em seus escritos.

Nesse sentido é que se pode compreender melhor o outro texto das Obras Morales de D. Francisco Manuel de Melo que mencionamos: Vitoria del Hombre sobre el Combate de Virtudes y Vicios. O estudo mais detalhado da Vitoria del Hombre ainda é o de Giacinto Manuppella, "Acerca do Cosmopolitismo Intelectual de D. Francisco Manuel de Melo", embora o autor desconheça que a obra seja uma tradução (bastante "livre") de um tratado de Jean-François Senault: De l'usage des passions (1642). ${ }^{302}$ Logo na primeira frase de seu estudo, Manuppella afirma que "D. Francisco Manuel de Melo consignou a sua inequívoca profissão de fé antiestóica numa obra de largo fôlego", referindo-se justamente à Vitoria del Hombre. ${ }^{303}$ Asseverar, assim, que é patente o "antiestoicismo" do texto de D. Francisco Manuel, talvez devido a uma interpretação superficial de seu subtítulo "Triunfo de la Filosofia Cristiana contra la

\footnotetext{
${ }^{299}$ El Fenis de Africa, Parte I, Livro I, Ação 26, p.206.

${ }^{300}$ Idem, ibidem, p.206.

${ }^{301}$ Sobre essa questão, vale lembrar o estudo de Werner Jaeger: Cristianismo primitivo e Paideia grega. Trad. Teresa Louro Perez. Lisboa: Edições 70, 2002.

${ }^{302}$ De l'usage des passions. Texte revu par Christiane Frémont. Paris : Fayard, 1987.

303 Manuppella, G. "Acerca do Cosmopolitismo Intelectual de D. Francisco Manuel de Melo", op.cit., p.59.
} 
Doctrina Estoyca", parece-nos um pouco precipitado. Quevedo, por exemplo, também visava ao "triunfo" da filosofia cristã, mas nem por isso é possível dizer que o espanhol era um "antiestoico" (como vimos, Quevedo, inclusive, declarou buscar um ethos estoico para se guiar na vida).

É preciso, então, examinar com mais cuidado a presença da doutrina estoica na Vitoria del Hombre. Esse tratado moral, composto por onze livros, discute o uso das paixões: o homem deve dominar suas paixões com o auxílio da razão que, diferentemente do que defendiam os estoicos, não é autossuficiente para exercer tal domínio, dependendo sempre da iluminação da graça divina. Outra divergência fundamental desse tratado com a doutrina estoica, além da necessidade da graça, é a valorização das paixões: estas não devem ser extirpadas ou extintas, como queriam os filósofos da Stoa, mas controladas ou moderadas e reutilizadas pelos homens, pois toda paixão, com a ajuda da razão e da graça, pode ser transformada em virtude. É o que apreendemos, por exemplo, deste trecho da "Introdução" da obra:

porque supuesto, que nuestras Passiones, sean desordenadas, y que el Pecado, las reduxesse a un punto, donde se halla más cierta la culpa, que la inocencia; todauia estamos ciertos, que la Raçon, con la Gracia, las pueden emplear con utilidad; de tal suerte, que sin lisonja, me atreuo a decir, que no ay Passion humana tan indomita que no se pueda trocar en vna Virtud gloriosissima. ${ }^{304}$

O primeiro capítulo do livro I intitula-se "Defensa de las Passiones, contra la Doctrina Estoyca", em consonância com o subtítulo, já mencionado, da obra. Nesse capítulo, afirma-se que os estoicos erraram por soberbia ao tentarem "afogar" as paixões. A doutrina estoica das paixões é assim resumida: "Que ser vno esclabo de sus Passiones, es viuir en tyrania, y que es fuerça renunciar la liuertad, para obedecer insolentes domínios". ${ }^{305}$ Porém, mesmo Sêneca ("que consideramos, como el mayor eloquente, el más soberbio, discípulo, desta Escuela altiua”) teria admitido que o sábio também sentia, algumas vezes, movimentos internos e perturbadores, e ainda que não padecesse verdadeiras paixões, experimentava suas sombras e aparências. Com base nessa discussão é que é feita uma crítica bastante comum, em particular entre os autores

\footnotetext{
${ }^{304}$ Vitoria del Hombre, Livro I, "Introdución”, p.3.

${ }^{305}$ Idem, Livro I, "Defensa de las Passiones, contra la Doctrina Estoyca", p.15.
} 
dos séculos XVI e XVII, à filosofia da Stoa: se "los Estoycos tenian más altiuos dictamenes, no tenian por esto, más altos sentimientos. No culpauan ellos las Passiones todas, pero solamente su exercicio con ingeniosa cautela; pues sy alcançaron deseos de reprimillas, nunca conseguieron la esperança del vencellas". ${ }^{306}$ Em suma: os ditames estoicos estão muito além daquilo que um homem pode alcançar em suas ações. Por isso, é preciso saber usar as paixões, tornando-as virtudes, em vez de almejar em vão eliminá-las, já que elas são essencialmente humanas, intrasponíveis para um ser que não é constituído somente pela pureza da alma, mas também pelo pecado da carne. E os únicos soldados capazes de dominar as paixões, para que, moderadas, sejam utilizadas corretamente, são a razão e a graça, que devem agir em conjunto nessa "batalha interior".

No capítulo seguinte do livro I, define-se a paixão: "No es, en fin, la Passion outra cosa que vn Mouimiento del Apetito Sensitiuo, causado por la imaginacion de vn Bien, ó de vn Mal aparente, ó verdadero, que muda el cuerpo contra las leyes de la quietud natural". ${ }^{307}$ Essa definição, à semelhança de outras dos divulgadores da doutrina estoico-cristã nos séculos XVI e XVII, ecoa aquelas atribuídas aos estoicos, desde Cícero e Diógenes Laércio; mas não podemos deixar de reconhecer nela também uma evidente dependência das noções de psyché (e de suas divisões ou partes) que se encontram em Platão e em Aristóteles, em particular no De Anima deste último filósofo. Definidas, dessa maneira, as paixões no texto de D. Francisco Manuel de Melo, é necessário, então, saber quais são elas. Afastando-se um pouco dos "sentimientos de Platon, y de Aristoteles" e seguindo a "opinion de Agostino", entende-se que o amor é a única paixão que agita o homem, porque todos os movimentos que desordenam a alma não são outra coisa que amores disfarçados. Portanto,

sy ay muchas Passiones en el Hombre, es el Amor, el soberano de todas ellas; y que es tan absoluto Señor en su estado, que sus inferiores no emprenden cosa alguna, sino de baxo de sus mandamientos. Es el primer mobil que las lleua y como les dá el curso, les dá tambien el sosiego; el las retira y las aplaca, con su vista y sus exemplos. Tiene en fin el Amor

\footnotetext{
${ }^{306}$ Idem, ibidem, p. 16.

${ }^{307}$ Idem, Livro I, "Qual sea la Naturaleça de las Passiones, y en qual de la Potencias del Alma residen", p.27.
} 
tanto poder sobre las inclinaciones de nuestra Alma que su bondad, o su malicia, hace que nuestras inclinaciones, sean buenas, o malas. ${ }^{308}$

Por isso, conclui-se o livro I da Vitoria del Hombre assegurando-se ao amor a posição de "paixão mais violenta do homem". E à filosofia moral não cabe outra coisa senão dirigir o amor a um fim divino, "porque quando esta Passion fuere bien reglada, todas las otras la copiaran en sy mesmo; pues que el Hombre que bien supiere amar no será posseido de malos Deseos, ny vanas Esperanças", 309

No livro II, trata-se, em primeiro lugar, da corrupção da natureza causada pelo pecado original, que relegou ao homem, como castigo de sua culpa, a rebelião da carne contra o espírito. Devido a tal corrupção, a natureza tornou-se incapaz de regrar as paixões humanas e a razão, enfraquecida pelo pecado, passou a necessitar de socorro e ajuda para dominar esses movimentos da alma. Assim, foi preciso acudir à graça: "que en el Hombre, se hallan tantos excessos y contradiciones, que no puede la Raçon amansarlas consigo mesmo, y que padece males a quien la Naturaleça sin la Gracia no puede dar remedio". ${ }^{310}$ É apenas com a ajuda da graça que a razão pode moderar (e jamais eliminar completamente) as paixões; e esse é um dos aspectos fundamentais que diferenciam a filosofia cristã da doutrina estoica, "porque la Humildad cristiana, és enemiga de la vanidad Estoyca". ${ }^{311}$ Em termos cristãos, somente o excesso das paixões é culpável ou pernicioso, e não sua prática, como queriam os estoicos. Portanto, segundo Santo Agostinho, o verdadeiro inimigo é a concupiscência: estar isento dela é a perfeição, não segui-la é a batalha.

O livro III discute a condução das paixões, que é considerada uma das coisas mais gloriosas, porém mais difíceis, para se alcançar a vitória sobre o embate das virtudes e dos vícios. ${ }^{312}$ Dessa forma, o escravo mais miserável é o homem que se deixa levar por suas paixões. Estas são como grilhões que não prendem o corpo, mas o "íntimo da alma": a vontade, os pensamentos, os desejos. Por isso, os cativos das

\footnotetext{
${ }^{308}$ Idem, Livro I, "Del numero de las Passiones del Hombre", pp.37-38.

${ }^{309}$ Idem, Livro I, "Qual sea la mas violenta entre las Passiones del Hombre", p.46

${ }^{310}$ Idem, Livro II, "Que la Naturaleça por sy solamente no puede reglar las Passiones, del Hombre”, p.58.

${ }^{311}$ Idem, Livro II, "Que en el punto en que se hallan nuestras Passiones, és necessaria la Gracia para que se compongan", p.62.

312 "Pues sy la difficultad que acompaña esta pendencia espanta, la gloria que se le sigue, nos deue alentar el animo; porque el Cielo no la mira empresa más ilustre, ny la Tierra, la tiene más gloriosa: que ver vn hombre triunfante de sus Passiones" (Idem, Livro III, "Que no ay cosa más gloriosa, ny más difficil que la conducion de las Passiones", p.82).
} 
paixões, como também ensina Justo Lípsio no seu De Constantia, ${ }^{313}$ "por más que muden de tierra, jamás pueden mudar de condicion; son esclabos de baxo de los diademas, siruen a sus Passiones, quando señorean sus súbditos, y a toda parte donde se encaminan, allá van arrastando sus cadenas y conducindo sus señores dentro de sy proprios". 314

Desse modo, é preciso moderar as paixões para depois encaminhá-las em direção à virtude. Na busca por essa moderação, três coisas são fundamentais: em primeiro lugar, faz-se necessário reconhecer como a desobediência da paixão turba a alma; em segundo, deve-se persuadir a razão que esteja sempre vigilante sobre os "assuntos" (sugetos) que podem concitar as paixões, considerando sua natureza e movimentos, para que jamais enganem os homens por achá-los distraídos; por fim, deve-se, sobretudo, estudar a natureza das paixões a serem moderadas e conduzidas, porque algumas delas são violentas e para reduzi-las à obediência é necessário usar de severidades. Assim, somente depois de despojadas de sua ferocidade natural, ou seja, após as paixões serem domadas, é que entra em cena a razão dispondo-as utilmente, "por cuyos medios, no forma la Virtud disignios que no execute felizmente en sus $\mathrm{u}$ ayuda". ${ }^{315}$ E em qualquer estado em que se encontrem as paixões, a razão pode governálas, pois mesmo depois do pecado e desobediência dos primeiros "Pais", elas ainda mantêm alguma "sombra de pureça". Com argumentos muito semelhantes aos estoicos, afirma-se, então, que a fortuna consiste na disposição do homem e a vitória depende da força de seus braços. ${ }^{316}$

\footnotetext{
${ }^{313}$ O De Constantia libri duo (publicado em Antuérpia, em 1584), que teve grande repercussão em fins do século XVI e, principalmente, no século XVII, é um diálogo de caráter consolatório, cujos personagens são Lipsius e seu amigo Langius. Diante de um contexto turbulento (guerra dos espanhóis em Flandres, guerras religiosas, fome, epidemias etc.), Lipsius (o personagem) almeja fugir e se exilar em Viena. Porém, quando está partindo de Flandres, decide visitar seu amigo Langius, e este tenta persuadir Lipsius a não fugir, mas enfrentar, com constância, os males públicos. O principal intento do tratado é, como se verifica logo nos capítulos II e III do livro I, mostrar que fazer longas viagens não traz nenhum proveito para aquele que sofre com males interiores (que, como dizem os estoicos, são os únicos que realmente importam); ao contrário, viajar somente expõe tais males e não os cura, pois não adianta fugir dos lugares, mas sim das "paixões". As viagens não são remédios: elas, na verdade, intensificam as "doenças da alma"; o único remédio para estas é aquele que provém da sapiência e da constância: deve-se mudar de "ânimo" (animus), não de lugar.

${ }^{314}$ Vitoria del Hombre, Livro III, "Que no ay tan miserable esclabo como el Hombre, que se dexa lleuar de sus Passiones", p.86.

${ }^{315}$ Idem, Livro III, "Que será fuerça moderar nuestra Passiones para poder encaminarlas", p.99.

316 "Por lo qual nuestra Fortuna consiste en nuestra disposicion; nuestra Vitoria depende de nuestros braços; nuestra ventura anda vinclada a nuestro Deseo: en tal manera, que para adquirir todos estos Bienes, no es menester mayor animo, que el que Dios nos ha dado assistido de su Gracia" (Idem, Livro III, "Que en todo estado en que se hallen nuestras Passiones, las puede gouernar la Raçon", p.106).
} 
O livro IV da Vitoria del Hombre discorre sobre o "comércio" das paixões. Logo no começo desse livro, é feita, ou melhor, é reproduzida uma antiga e conhecida censura aos estoicos: a filosofia da Stoa "promete mudar los Hombres, y hacerlos casy iguales con los Dioses; eleuarles sobre la condicion mortal, y poner debaxo de sus plantas, los truenos, y las tempestades". ${ }^{317}$ Recordemos o que já dizia Diógenes Laércio sobre a doutrina estoica: “Os sábios são criaturas divinas, pois têm em si, por assim dizer, a divindade" (Vidas, VII, 119). Portanto, para um cristão, como Jean-François Senault ou D. Francisco Manuel de Melo, desnudar a alma de suas paixões é querer que o homem seja Deus, o que é um objetivo impossível defendido, com soberba, pela escola estoica. As paixões, na verdade, se corretamente utilizadas, são instrumentos das virtudes; ${ }^{318}$ idéia essa que se aproxima muita mais daquela dos peripatéticos, como declara o próprio D. Francisco Manuel no texto.

Contudo, embora as paixões sejam instrumenos das virtudes, são também fundamento e raiz dos vícios, estando de tal maneira imbricados esses dois "contrários" que se torna muito difícil distingui-los. Vale a pena ler o techo em que essa contradição é explicada e resolvida:

Finalmente hallamos, que el solar de las Passiones, no está más apartado de las rayas del Vicio, que vicino a las de la Virtud: y assy como en la primera confusion del Caos, el Fuego se hallaua de mistura con el Agua, en las Affeciones del Alma, está el Mal mesclado con el Bien, sacando destas funestas minas, el yerro, reuoluido con el oro. Deue por esto el Hombre hallarse siempre cuidadoso; y entendiendo, que encierra la Vida, y la Muerte dentro de sy mesmo, es obligado a gouernarse con tanta prudencia, como aquellos, que manejan el veneno, ó que caminan sobre la dificil, y peligrosa cumbre. ${ }^{319}$

O que novamente se assegura no livro IV é que não existem paixões que não possam ser transformadas em virtudes, acrescentando-se que os cristãos fazem um bom uso delas desde que visem à glória de Deus e à salvação de seus espíritos. Quanto às

\footnotetext{
${ }^{317}$ Idem, Livro IV, “Que las Passiones pueden ser el Cimiento de las Virtudes”, p.113.

318 "De aqui sacamos vna máxima indubitable entre los Filosofos donde se affirma: Que las Passiones, son los instrumentos de las Virtudes: y que ellas no tienen ocupaciones más nobles, que armarse en su fauor, pelear en su socorro, y vengarlas de sus enemigos. Porque assy como las madres nunca son tan animosas, como quando defienden sus hijos; los Affectos de nuestra Alma, nunca son más vigorosos, como quando defienden sus effectos" (Idem, ibidem, p.117).

${ }^{319}$ Idem, Livro IV, "Que las Passiones son tambien la rayz delos Vícios", pp.122-123.
} 
virtudes, seu exercício é uma eterna guerra contra os vícios, sendo que elas nos foram dadas "solamente para assistirnos en el progresso desta vida peligrosa; y que son grados para subir azia aquella altíssima felicidad, que consiste en la possesion del sumo Bien". ${ }^{320}$ E um dos exercícios mais úteis e difíceis das virtudes é justamente governar as paixões, destacando-se os papéis fundamentais das quatro principais virtudes - a prudência, a temperança, a fortaleza e a justiça -, que devem ser empregadas em conjunto nessa difícil guerra. “Assy la Naturaleça acordandose con la Gracia, quedará la Culpa destruída, y el Hombre vitorioso. Los mouimientos de su Alma siendo niuelados por la Raçon, goçarán de vn perfeitissimo sosiego". ${ }^{321}$

Já o livro $\mathrm{V}$ trata do poder das paixões sobre a vontade dos homens. O melhor e mais seguro remédio para evitá-las é seu exame, reconhecendo-as como correntes que escravizam o homem. Para nos auxiliar no governo das paixões todas as ciências e artes são defeituosas, a não ser a filosofia moral, que é aquela que mais pode nos ajudar a "vencer la profia, y la batalla de enemigos, que son tan obstinados, como insolentes". 322

A partir do livro VI até o fim da Vitoria del Hombre são estudadas as principais paixões humanas, começando por aquela que origina todas as outras: o amor, que é "vn congregado de todas las Passiones del Hombre, el qual segun sus diuersos estados reciue ó toma nombres differentes". ${ }^{323}$ Isso porque, assim como a grandeza dos rios deriva de sua nascente, todas as paixões tomam sua primeira força daquela primeira “inclinação", que é o amor. Este, além disso, é tão soberano em sua condição principal que não se resiste jamais à sua vontade e todas as paixões executam sempre seus mandamentos; "y como el mouimiento de la Luna causa el fluxo, y refluxo del Mar; assi causa el Amor, la Paz, y la Inquietud de nuestro espiritu". 324

Esse poderoso amor se divide em "natural" e "sobrenatural": este último é aquele que Deus derrama nos corações dos homens, para torná-los capazes de amá-lo como o Pai, ou seja, trata-se do amor divino; enquanto o primeiro é aquele que a natureza gravou nas almas dos homens, para ligá-los aos objetos que lhes parecem agradáveis. Mas o amor natural divide-se, ainda, em "espiritual” e "sensível”: aquele reside na vontade, merecendo mais o nome de virtude do que de paixão; já o amor sensível se acomoda na parte inferior da alma, tendo um tão grande "comércio" com os

\footnotetext{
${ }^{320}$ Idem, Livro IV, "Que el principal exercício de la Virtud, es el gouierno de las Passiones humanas", 137.

${ }^{321}$ Idem, ibidem, p. 142.

${ }^{322}$ Idem, Livro V, "Que las Artes engañan a los Hombres por el remedio de sus Passiones", p.160.

${ }^{323}$ Idem, Livro VI, "De la Naturaleça, de las Propriedades, y de los Effetos del Amor", p.180.

${ }^{324}$ Idem, ibidem, p. 182.
} 
sentidos que costuma pedi-los emprestados ao corpo para o exercício de suas ações - "y este tal Amor, es la verdadera Passion". ${ }^{325}$ Embora seja esse amor sensível a verdadeira paixão, o amor humano, seja de qual espécie for, nunca está satisfeito, senão quando descansa em Deus, sendo, portanto, sempre imperfeito: o seu essencial defeito se dá tanto pela "avareza" quanto pelo "excesso". E o amor que os homens dedicam às mulheres, em particular, é uma turbulenta paixão que é difícil de regular-se, pois só é tido como verdadeiro se for excessivo: "Lo que sobre todo es dificil de regularse; es aquella turbulenta Passion, que procede del Amor de los Hombres, exercitado con las mugeres. Porque ello viene a ser aconsejar vn Affecto, que no toma consejo sy no consigo. Vn Affecto, que para creerse, que es verdadero, es menester, que sea excessiuo". 326

Tal poder excessivo do amor, que não ouve nem mesmo os conselhos da razão, é também afirmado na produção retórico-poética do século XVII. Na segunda parte da Constante Florinda, ${ }^{327}$ uma epopeia em prosa seiscentista ${ }^{328}$ de Gaspar Pires de Rebelo, o amante Arnaldo, em suas andanças pelo mundo à procura de sua amada Florinda, foi para a França "e antes que chegasse à Cidade de Avinhão, (...) viu um monte alto, cheio de muito arvoredo, ao qual subiu para que passasse aquele dia em as negras sombras contemplando suas tristezas". ${ }^{329}$ Nesse monte, viu uma fonte e, seguindo "um cano de

\footnotetext{
${ }^{325}$ Idem, ibidem, p. 183 .

${ }^{326}$ Idem, Livro VI, "Del buen vso del Amor", p.215.

327 Os Infortúnios trágicos da constante Florinda, de Gaspar Pires de Rebelo, foram publicados em Lisboa, em 1625. Devido ao sucesso alcançado pelo texto, veio a público, em 1633, uma continuação intitulada Segunda parte da Constante Florinda, em que se trata dos infortúnios que teve Arnaldo buscando-a pelo mundo. A Constante Florinda (esse é o título pelo qual as duas partes da obra, em conjunto, ficaram conhecidas), foi muito lida nos séculos XVII e XVIII. Em nossa já mencionada dissertação de mestrado, Narração e doutrina na Constante Florinda: exempla estóicos para a vida cristã, analisamos as duas partes que compõem essa epopeia em prosa seiscentista portuguesa.

${ }^{328}$ Acerca desse gênero, a chamada "epopeia em prosa", Adma Muhana esclarece que não há sequer uma única preceptiva seiscentista a seu respeito, a não ser num manuscrito incompleto intitulado Argumento de Heliodoro (1633), de Manuel Pires de Almeida. Tal gênero remonta a textos gregos e bizantinos, tais como As etiópicas, de Heliodoro, e Leucipe e Clitofonte, de Aquiles Tácio (só para citar dois importantes modelos para os autores seiscentistas), e afirma-se no século XVII ibérico (agregando a esses modelos antigos elementos das novelas de cavalaria), com obras como El peregrino en su patria, de Lope de Vega, Los trabajos de Persiles y Sigismunda, de Cervantes, e a referida Constante Florinda de Gaspar Pires de Rebelo. Enfim, a epopéia em prosa seiscentista, conforme a definição de Adma Muhana, é uma "imitação comum de ação grave, una e extensa, narrada sem metro e com pensamento ornado, tendo por ofício mover os ouvintes pelo deleite e pelo ensinamento." (Muhana, A. A epopéia em prosa seiscentista, op.cit., p.26).

${ }^{329}$ Segunda parte da Constante Florinda, capítulo XXVII, p.208. Citamos o texto com base na edição que Artur Henrique Ribeiro Gonçalves apresentou em sua tese de doutorado: Infortúnios Trágicos da Constante Florinda de Gaspar Pires de Rebelo: Uma Novela de Amor e Aventuras Peregrinas. Vol. II. Lisboa: Universidade Nova de Lisboa, 2000. Vale lembrar que há uma edição, mais recente, das duas partes da obra: Infortúnios trágicos da Constante Florinda. Edição de Nuno Júdice. Lisboa: Teorema, 2005. Por fim, é importante lembrar que Adma Muhana também publicou uma edição da epopeia em
} 
pedra natural", foi descendo uns degraus de pedraria até entrar "em umas casas debaixo do chão fundadas, a quem servia de tecto a terra sustentada em grossas colunas, e a compasso certas aberturas que lhes comunicavam a claridade necessária". ${ }^{330}$ Ao perscrutar os cômodos dessas casas, Arnaldo se deparou com um "triste queixoso", chamado Laureano. Após este ter dado conta de sua trágica vida àquele, mostrou, então, ao peregrino-amante Arnaldo, sempre desejoso e em busca constante de sua amada Florinda, as "pinturas exemplares" que ornavam uma pequena sala dessas "curiosas casas"; pinturas que não só deleitam como também ensinam, pois "criam em o coração um desejo que o está movendo a buscar as virtudes". ${ }^{331}$ Se essas exemplares pinturas, que representam a "virtude", a "verdade", a "justiça", a "misericórdia", a "paz", a "prudência", o "amor" e a "negligência", movem Arnaldo, que as vê, a buscar virtudes, as suas ecfrases, ${ }^{332}$ feitas pelo narrador da Constante Florinda, procuram, igualmente, mover os leitores, como se estivessem vendo-as, a seguir virtudes e fugir dos vícios. Assim, para atingir tal propósito, é que se pinta o amor:

Em ũa das frontarias da sala estava pintado o AMOR, desta maneira: posto em um carro, pelo qual tiravam quatro cavalos a toda a pressa. $\mathrm{E}$ entre eles ũas letras, que deziam desta maneira: «O Amor não se sujeita a conselho, nem se refreia com a vergonha, nem se aplaca com a razão». Tinha o rosto corado, à vista de ũa mulher que tinha diante de si, com esta letra: «Envergonha-se o Amor com a dificuldade». Vinha despojado de vestido, com uma letra que dezia: «De liberal não tem que vestir». Em uma mão tinha um arco e na outra uma chama de fogo, e entre elas umas letras nesta maneira: «O que escapa da seta vai morrer em a chama». Cingia espada e tinha asas em os pés, com esta letra: «Para os fortes armas, para os ligeiros asas». Estava posto entre Hércules, que foi de muitas obras, e o Deus Mercúrio, que era Deus da

prosa seiscentista de Rebelo, mas apenas de sua primeira parte: Infortúnios trágicos da constante Florinda. Organização, notas e posfácio de Adma Muhana. São Paulo: Globo, 2006.

${ }^{330}$ Idem, ibidem, p. 209.

${ }^{331}$ Idem, capítulo XXXII, p.224.

332 "Na ekphrasis, o narrador se define como intérprete (exégetes) da interpretação que o pintor fez de sua matéria. Assim, geralmente antecipa a exposição das imagens fictícias com a declaração de que as viu diretamente ou que viu uma cópia delas. Esse "como se" é fundamental na ficcionalização da enargeia, sendo necessário observar que o autor finge transferir para a enunciação do narrador uma imagem pictórica com que compõe o enunciado como se efetivamente fizesse as passagens entre pintura e discurso indicadas por Filóstrato de Lemnos quando se autonomeia "hermeneuta", em seus Eikones, comentando sua prática como "exercício de eloqüência"”. (Hansen, J. A. "Categorias epidíticas da ekphrasis". In: Revista USP, São Paulo, n.71, 2006, p.86). 
Eloquência, e em roda estas letras: «Para ser verdadeiro, há-de ter mais de Hércules que de Mercúrio». 333

O que se sobressai nessa pintura, isto é, na ecfrase que o narrador faz dela, é aquele poder soberano do amor: ele não se aplaca nem mesmo com a razão, diz a primeira sentença. Como se observa em diversos textos da filosofia estoica, especialmente naqueles de Sêneca, e também da doutrina estoico-cristã, em particular naqueles de Justo Lípsio, a uirtus depende da recta ratio. ${ }^{334}$ Aquele que não se guia pela razão não é um sapiens, mas um stultus; é alguém que, por exemplo, de tão liberal fica sem ter o que vestir. E a pintura, descrita pelo narrador, parace querer mostrar justamente que o amor, irrefreável, torna os homens "estultos"; se ele ignora a razão e perturba o "ânimo", ou melhor, a "alma", trata-se, portanto, de uma típica paixão. Para não restar dúvida, vejamos como nascem as paixões, seguindo a explicação de Sêneca em seu tratado que é uma das principais fontes antigas sobre o tema, o De Ira:

Et ut scias quemadmodum incipiant adfectus aut crescant aut efferantur, est primus motus non uoluntarius, quasi praeparatio adfectus et quaedam comminatio; alter cum uoluntate non contumaci, tamquam oporteat me uindicari cum laesus sim, aut oporteat hunc poenas dare cum scelus fecerit; tertius motus est iam inpotens, qui non si oportet ulcisci uult sed utique, qui rationem euicit. (De Ira, II, IV, 1). ${ }^{335}$

No nascimento do adfectus, há primeiro um movimento involuntário, uma espécie de preparação da "paixão"; depois, um segundo movimento que, embora voluntário, não é contumaz; por fim, surge o terceiro movimento que, totalmente desordenado, vence a razão. A razão vencida, não cabe mais o discurso: talvez por isso o amor, ainda que verdadeiro, não possa contar com Mercúrio, pois, como Hércules, é

\footnotetext{
${ }^{333}$ Segunda parte da Constante Florinda, capítulo XXXII, p.225.

${ }^{334}$ Para exemplificar, no já mencionado tratado de Lípsio, De Constantia libri duo, a constância, uma das principais virtudes para os estoicos, é definida como uma resistência reta e imóvel da alma que não é aumentada nem diminuída pelas coisas exteriores ou fortuitas: "Constantiam hic appello rectum et immotum animi robur non elati externis aut fortuitis non depressi" (De Constantia, I, 4). Para se alcançar a firmeza interior que a constância proporciona, é preciso se guiar pela "reta razão" (orthos logos, recta ratio) e não pela "opinião" (doxa, opinio). A ratio tem uma origem divina, como Sêneca afirmou: "Ratio autem nihil aliud est quam in corpus humanum pars diuini spiritus mersa" (Epistulae ad Lucilium, LXVI, 12); enquanto a opinio é apenas uma sombra e vã imagem da razão, como um navio vazio que vaga pelo mar levado por todo e qualquer vento: "Vt nauis vacua \& inanis circumagitur in mari omni vento: sic in nobis vaga illa mens, quam pondus \& tamquam saburra Rationis non stabiliuit" (De Constantia, I, 5).

${ }_{335}$ Edição utilizada: De ira. Dialogues, t.1. Texte établi et traduit par A. Bourgery. Paris: Les Belles Lettres, 1951.
} 
pura força. É o amor, enfim, como a ira, um impetus que ultrapassa a razão e a carrega consigo ("illa est ira quae rationem transsilit, quae secum rapit"). ${ }^{336}$

Na poesia do século XVI, essa guerra entre o amor e a razão, que procuramos desenvolver no campo da doutrina estoico-cristã, é descrita num soneto de Sá de Miranda, que também é uma importante autoridade poética quinhentista para a poesia seiscentista portuguesa.

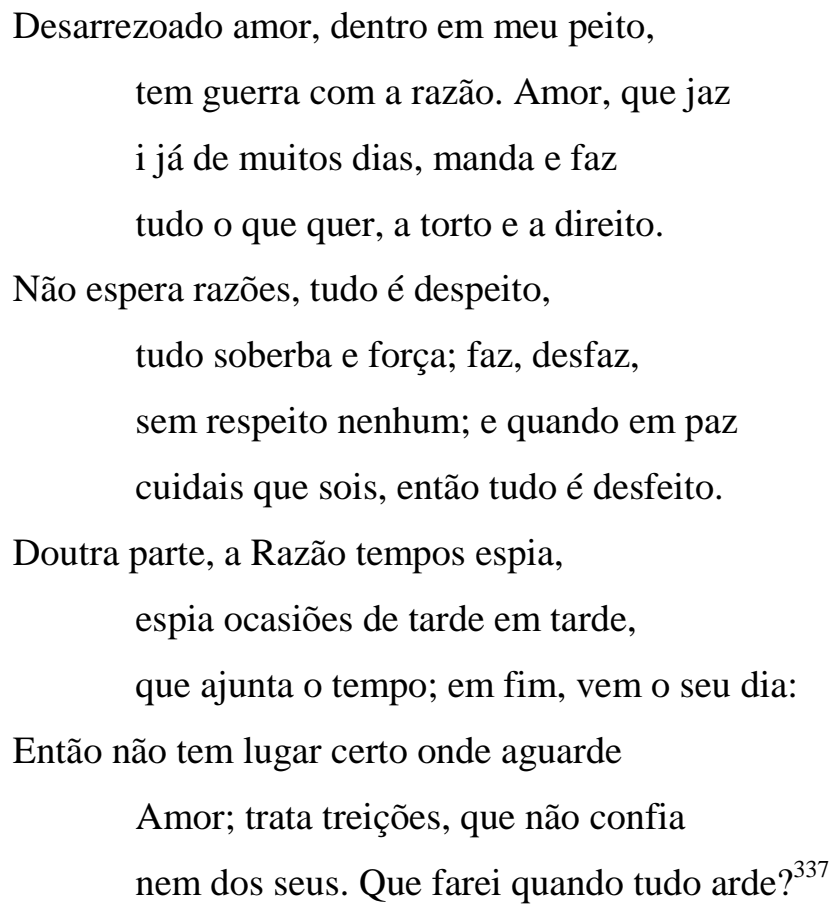

Como afirma T. F. Earle, diversos pesquisadores já apontaram a presença da filosofia estoica nas obras de Sá de Miranda, sendo que "a primeira pessoa a fazê-lo foi o biógrafo anónimo de Sá de Miranda do séc. XVII, que a ele se refere como «ficando só consumandose no estudo da Philosophia Moral \& Estoyca a que sua natureza o inclinava»". ${ }^{338}$ Acrescenta, ainda, Earle que, possivelmente, o poeta teria se informado sobre a doutrina estoica e os sábios estoicos antigos, sobretudo, nas Vidas de Diógenes Laércio, que já contavam com uma tradução latina no século XV (Veneza, 1475). Além disso, o estudioso ressalta que "é também possível que [Sá de Miranda] tenha conhecido bem o estoicismo como resultado da revivescência em Espanha no séc. XV do interesse

\footnotetext{
${ }^{336}$ De Ira, II, III, 4.

${ }^{337}$ Sá de Miranda, F. de. Obras Completas. Volume I. Texto fixado, notas e prefácio de Rodrigues Lapa. $5^{\text {a }}$ edição. Lisboa: Sá da Costa, 2002, p.293.

${ }^{338}$ Earle, T. F. Tema e imagem na poesia de Sá de Miranda. Tradução de Isabel Penha Ferreira. Lisboa: IN - CM, 1985, p.72.
} 
por Séneca". ${ }^{339}$ Nesse sentido, embora não seja mencionado por Earle, é preciso salientar que Karl Alfred Blüher fez um estudo detalhado da recepção das obras de Sêneca na Espanha, desde o século XIII até o XVII. Blüher destaca, por exemplo, a importância da primeira edição crítica da Opera Omnia de Sêneca, feita por Erasmo (Basileia, 1515), que "se debe estimar tanto más cuanto que hasta el final del siglo XVI fue la única edición crítica que, completada y corregida, quedó disponible en el mercado del libro, también en España". 340

Assim sendo, no soneto citado, o amor é qualificado como "desarrezoado" e, por isso mesmo, sempre em guerra com a razão. Dentro do peito da persona lírica, não há espaço para a razão, pois tudo está tomado pelo amor-paixão que, como uma febre, ${ }^{341}$ faz com que tudo arda naquela persona. É o amor, portanto, uma doença que torna o amante irracional e infeliz, ou melhor, em termos estoicos, não permite que ele viva secundum naturam; isso porque, como já mencionamos, viver segundo a natureza é, conforme Sêneca, o mesmo que ter uma vida feliz: "Idem est ergo beate uiuere et secundum naturam" (De Vita Beata, VIII, 2).

Na poesia seiscentista, essa ardência ou dor causada pela paixão amorosa é glosada com um estilo em que antíteses e metáforas agudas tornam tal ardor uma "confusão cega", que toma conta do amante e o faz perder a razão e confundir os sentidos, como se nota no seguinte soneto anônimo da Fênix Renascida, no qual se versam, engenhosamente, as "borrascas del amor":

\footnotetext{
El aire ronco, el mar embravecido,

Triste el Sol, pardo el cielo, obscuro el dia,

Sin norte, sin timon, sin luz, sin guia,

Syrtes toco, ondas lucho, esferas mido.

Naufraga la razon, ciego el sentido

A mucho golfo poco leño fia,

Donde el cuidado haziendose porfia

Rocas busco, el mar dexo, el puerto olvido.
}

\footnotetext{
${ }^{339}$ Idem, p.73.

${ }^{340}$ Blüher, K. A. Séneca en España: investigaciones sobre la recepción de Séneca en España desde el siglo XIII hasta el siglo XVII, op.cit., p.235.

${ }^{341}$ É curioso observar que Bluteau define a "febre" como uma doença que causa um calor excessivo e que se origina, justamente, no coração: "FEBRE. Doença, procedida de calôr preternatural, ou intemperie calida, \& secca do sangue, \& dos humores, cuja effervescencia tem seu principio no coraçaõ, \& delle se communica a todo o corpo pelas veas, \& arterias, com movimento desordenado, \& outros symptomas, segundo a calidade, \& differença das Febres." (Vocabulario Portuguez, \& Latino, op.cit., volume 4, verb. “febre", p.54).
} 
Roto el fragil baxel de la esperança,

Hecho caos el juizio considero,

Tempestad el remedio, el mal bonança.

Oh ciega confusion, pues quando espero

Besar libre la playa, a una mudança

Fuego surco, ardo en agua, en aire muero! $!^{342}$

Nos versos desse soneto, há diversos "cortes" ou "partições" que são bastante frequentes nos poemas seiscentistas em geral, sendo a presença constante dessas "cesuras", de acordo com Maria do Socorro Fernandes de Carvalho, "um exemplo de especificidade preceptiva (...), aspecto formal explorado na poesia desse período tendo em vista o artifício muito usado da plurimembração dos versos". ${ }^{343}$ No entanto, ainda no quartel final do século XVI, Fernando de Herrera, em suas Anotaciones às obras de Garcilaso, já valorizava esse "cortar o verso", em especial nos sonetos: "No dexarè de traer esta adversión, pues se ofrece lugar para ello; que cortar el verso en el Soneto (...) no es vicio sino virtud, i uno de los caminos principales para alcanzar l'alteça $\mathrm{i}$ hermosura del estilo". 344

Desse modo, na mencionada composição anônima da Fênix Renascida, desenvolve-se, alegoricamente, ${ }^{345}$ a metáfora náutica das "borrascas del amor". Com os versos cortados do primeiro quarteto, constrói-se uma tota allegoria (ou alegoria perfeita ou, ainda, enigma) que, segundo João Adolfo Hansen, “é a alegoria totalmente fechada sobre si mesma, não se encontrando nela nenhuma marca lexical do sentido próprio representado". ${ }^{346}$ É enigmático esse quarteto, porque não há qualquer referência ao sentido próprio, que sabemos ser o amoroso, e sim apenas ao figurado sentido náutico, partindo-se os versos como as borrascas partem os navios nos mares. Porém, a partir do segundo quarteto, começa-se a indicar que as tempestades que enfrenta a persona lírica não se encontram no mar, pois causam o naufrágio da razão e cegam o sentido. Assim, perdida a razão e cego o sentido, destrói-se o baixel (que já era frágil) da esperança e ficando o juízo caótico, a tempestade é julgada remédio e o mal,

\footnotetext{
${ }^{342}$ Fênix Renascida, tomo V, p.120.

${ }^{343}$ Poesia de Agudeza em Portugal, op.cit., p.235.

${ }^{344}$ Apud Echarri, E. D. Teorías Métricas del Siglo de Oro: apuntes para la historia del verso español. Madrid: Consejo Superior de Investigaciones Cientificas, 1949, p.166.

${ }^{345}$ Conforme a definição de Lausberg, citada por João Adolfo Hansen, "a alegoria é a metáfora continuada como tropo de pensamento, e consiste na substituição do pensamento em causa por outro pensamento, que está ligado, numa relação de semelhança, a esse mesmo pensamento." (Alegoria construção e interpretação da metáfora. São Paulo: Hedra; Campinas: Editora da Unicamp, 2006, p.7).

${ }^{346}$ Idem, p.54.
} 
bonança. Tal "cega confusão" é resolvida no último terceto, mas resolvê-la é torná-la ainda mais confusa: o agudo verso final, partindo-se, recolhe os despojos dessas borrascas amorosas, espalhados, em versos quebrados, ao longo de todo o soneto, para exprimir numa confusão de sentidos o sofrimento amoroso que é, enfim, sulcar o fogo, arder na água, morrer no ar: impossíveis de amor.

Realizar impossíveis é a que incita o cego amor, pois ele é, ao mesmo tempo, tempestade e confusão: causa e consequência do naufrágio da razão. Dessa maneira, tanto naquele soneto de Sá de Miranda quanto neste anônimo da Fênix Renascida, o desarrazoado ou cego amor provoca sofrimento por ser contrário à razão; por isso, é ele, tantas vezes, também considerado loucura, como nestes versos de um romance atribuído a Antônio Fonseca Soares:

Amor: yá pierdes el nombre;

locura os llamen desde oy:

pues siguir un impossible,

és más locura, que amor. ${ }^{347}$

Como já destacamos, é princípio fundamental da ética estoica antiga o secundum naturam uiuere, sendo a natureza identificada com a razão. Na doutrina estoico-cristã, esse princípio é desenvolvido e interpretado, por exemplo, por Justo Lípsio em seu "Manual" da filosofia estoica (Manuductio ad Stoicam Philosophiam). ${ }^{348}$ Na dissertação 13 do livro II desse tratado, discute-se em que consiste o fim último ou sumo bem para os estoicos. Esclarece Lípsio, então, que, para os gregos, o "fim" é o telos, num sentido filosófico diferente do sentido ordinário que significa a efetuação e o acabamento da coisa iniciada. Para exemplificar, são citados diversos autores antigos sobre a noção de fim (ou finalidade), como Aristóteles, para quem o conhecimento do fim é útil e de grande importância para a vida: assim como os arqueiros têm um alvo, nós buscaremos melhor o que convém se tivermos um objetivo ou finalidade (Ética a

\footnotetext{
347 Obras Poeticas de Antonio da Fonseca Soares chamado depois na Relligiaõ Fr. Antonio das Chagas. $7^{o}$. Tomo; adquiridas de proximo depois de já encadernado o $6^{\circ}$ Tomo, e ordenadas na ordem que aqui se acham, e escritas por Antonio Corr ${ }^{a}$ Vianna. Lisboa, 1782. Lisboa: Biblioteca da Ajuda, Ms. 49-III-80, p.434.

${ }^{348}$ Esse tratado de Lípsio, Manuductio ad Stoicam Philosophiam, foi publicado pela primeira vez em Antuérpia, em 1604. Porém, consultamos o texto na seguinte edição das "Obras Completas" de Lípsio: Opera Omnia. Tomus Quartus. Antuerpiæ: Ex Officina Plantiniana, Balthasaris Moreti, 1637. Vale lembrar que Jacqueline Lagrée fez uma edição bilingue de uma parte do livro II desse Manual de Lípsio (Juste Lipse et la Restauration du Stö̈cisme, op.cit., pp.160-205).
} 
Nicômaco, I, 1, 1094b, 22). Se para o mesmo Aristóteles o fim último seria a felicidade (Idem, I, 5), para os estoicos, o objetivo (scopus) proposto é outro: o verdadeiro fim é perseguir a felicidade ("finem vero esse felicitatem assequi”). ${ }^{349} \mathrm{O}$ finem verum dos estoicos é secundum Naturam vivere, conforme o título da dissertação XIV, na qual são referidas as diversas interpretações que foram desenvolvendo o tópico. Referindo as Éclogas de Estobeu e as Vidas de Diógenes Laércio, Lípsio identifica a origem da expressão no convenienter vivere (homologoumenos zen) de Zenon. Nesse sentido e abreviando ainda mais a expressão, é que, para Cícero, o sumo bem dos estoicos seria, simplesmente, a homologia ou a convenientiam (De Finibus, III, 21). ${ }^{350}$ A essa definição inicial de Zenon, foi Cleantes quem adicionou a natureza: convenienter naturae vivere, e, mais ainda, viver de acordo com a natureza comum. Essa natura communis é a Lei e a Razão universais presentes na totalidade do mundo e em suas partes, ou seja, é o próprio Deus. ${ }^{351}$ A tese seguinte é a de Crisipo: a natureza própria ao homem é a Razão, e deve-se viver em conformidade com a ratio perfecta. Para comprovar o que afirma, Lípsio cita Sêneca: "Quum sola ratio perficiat hominem (id est perfecte bonum faciat) sola Ratio perfecta beatum facit” (Ep. ad Luc., LXXVI, 9). ${ }^{352}$ A quarta e última tese é aquela que define o fim último como "viver segundo a virtude" e está de acordo com as demais ("virtus rationem sequitur, haec naturam, ista Deum"), sendo todas as quatro verdadeiras, pois seguem e conduzem a Deus; e o verdadeiro sábio é aquele que imita Deus. Enfim, o soberano bem está na virtude, ou melhor, somente ela é o Bem ("solam illam Bonum esse"). ${ }^{353}$

Portanto, aquele amor, desarrazoado, cego e louco, é um viver contrário à natureza, à razão, à virtude, ao bem, que não segue nem conduz a Deus - é paixão, é pecado. E o padecimento do amante é o seu natural castigo.

É preciso salientar, entretanto, que a condenação do amor-paixão, na filosofia antiga, não é feita unicamente pelos estoicos. Um epicurista, como Lucrécio, também recrimina esse cúpido amor (De Rerum Natura, IV, vv.1058-1191). ${ }^{354}$ Isso porque, nos

\footnotetext{
${ }^{349}$ Manuductio ad Stoicam Philosophiam, II, 13.

${ }^{350}$ Idem, II, 15.

${ }^{351}$ Idem, II, 16.

${ }^{352}$ Idem, II, 17.

${ }^{353}$ Idem, II, 18-20.

${ }^{354}$ Alain Gigandet expõe e analisa as discussões sobre o amor presentes no final do livro IV do De Rerum Natura no seguinte artigo: "Lucrécio e o amor conjugal. Um remédio para a paixão?" In: Besnier, B.; Moreau, P. F.; Renault, L. (orgs.). As paixões antigas e medievais: teorias e críticas das paixões. Tradução de Miriam Campolina Diniz Peixoto; revisão técnica de Mariana Paolozzi Sérvulo da Cunha. São Paulo: Edições Loyola, 2008, pp.109-127.
} 
próprios fragmentos atribuídos a Epicuro, o prazer, definido como "princípio e fim da vida feliz", o primeiro bem ou o bem inato que determina toda escolha ou recusa, decorre da "ausência de dores, da moderação nos afetos e da disposição de espírito que se mantém nos limites impostos pela natureza". Mais ainda:

Quando dizemos, então, que o prazer é fim, não queremos referir-nos aos prazeres dos intemperantes ou aos produzidos pela sensualidade, como crêem certos ignorantes, que se encontram em desacordo conosco ou não nos compreendem, mas ao prazer de nos acharmos livres de sofrimentos do corpo e de perturbações da alma. ${ }^{355}$

Por isso, o amor-ardor é vituperado por Lucrécio, já que é a única coisa que "quanto mais possuímos, tanto mais incedeia o nosso peito com terríveis desejos". 356 Trata-se, então, de um afeto imoderado, de uma incessante perturbação, e não do prazer, princípio e fim da vida feliz. O amante é assim comparado a um homem que, em sonhos, está ardendo de sede e a quem não é dado nenhum líquido que possa extinguir esse ardor de seus membros, mas que recorre a simulacros e se atormenta em vão, morrendo de sede nas torrentes do rio em que, ao mesmo tempo, ele bebe:
Vt bibere in sommis sitiens quom quaerit, et umor non datur, ardorem qui membris stinguere possit, sed laticum simulacra petit frustraque laborat, in medioque sitit torrenti flumine potans: sic in amore Venus simulacris ludit amantis, nec satiare queunt spectando corpora coram, nec manibus quicquam teneris abradere membris possunt, errantes incerti corpore toto. ${ }^{357}$

\footnotetext{
${ }^{355}$ Antologia de textos de Epicuro. Tradução e notas de Agostinho da Silva. In: Os Pensadores. Volume V. São Paulo: Abril Cultural, 1973, p.25.

${ }^{356}$ Lucrécio. Da natureza. Tradução e notas de Agostinho da Silva. In: Os Pensadores. Volume V, op.cit., p.101. "Unaque res haec est, cuius quam plurima habemus, / tam magis ardescit dira cuppedine pectus." (De Rerum Natura, IV, vv.1089-1090). Para as citações do texto latino, utilizamos a seguinte edição: De la nature / De rerum natura. Traduction, introduction et notes de José Kany-Turpin. Paris: GF Flammarion, 1997.

357 "Assim como aquele que em sonhos, cheio de sede, procura que beber e ninguém lhe dá com que possa extinguir o ardor dos membros, e busca imagens de líquidos, em vão se atormenta e fica cheio de sede, ao mesmo tempo que bebe das torrentes de um rio, assim também Vênus, no amor, ilude os amantes com a imagem: não podem saciar-se olhando o corpo que se lhes apresenta nem podem com as mãos arrancar seja o que for dos delicados membros, e incertos erram por todo o corpo." (Da natureza, op.cit., p.101).
} 
(De Rerum Natura, IV, vv.1097-1104).

Contudo, a esse amor que engana, com simulacros, os amantes nunca saciados, Lucrécio opõe o amor gerado pelo costume ou hábito (consuetudo), que não é um desejo impaciente e imoderado, causa de perturbações e sofrimentos, mas algo como leves pancadas que, por serem frequentes, vencem com o tempo a toda resistência ou, ainda, gotas de água que, caindo sobre a pedra, perfuram-na pouco a pouco: "Quod superest, consuetudo concinnat amorem; / nam leuiter quamuis quod crebro tunditur ictu, / uincitur in longo spatio tamen atque labascit. / Nonne uides etiam guttas in saxa cadentis / umoris longo in spatio pertundere saxa?" (Idem, IV, vv.1283-1287). Dessa forma, àquele amor-paixão, sempre insaciável, contrapõe-se este amor constante, resultado do hábito, que leva alguém a querer partilhar a vida com uma mulher, não por ela ser bela, e sim pelos seus costumes, pelos seus modos, pela sua maneira de cuidar do corpo $^{358}$ : enfim, trata-se de um afeto que, moderado pela razão, é contínuo prazer.

Todavia, um prazer governado pela razão é inverosssímil numa poesia que, embebida na doutrina cristã, faz emergir, frequentemente, o pecado, a culpa e o castigo próprios à condição humana. Assim, o cego amor humano é, quase sempre, desconcerto e só se faz amigo da razão para "não deixar culpa sem castigo", como se lê nesta primeira estância da canção $A$ instabilidade da Fortuna, atribuída a Camões:

A instabilidade da Fortuna,

Os enganos suaves de Amor cego

(Suaves, se duraram longamente),

Direi, por dar à vida algum sossego;

Que, pois a grave pena me importuna,

Importune meu canto a toda a gente.

E se o passado bem co mal presente

Me endurece a voz no peito frio,

$\mathrm{O}$ grande desvario

Dará de minha pena sinal certo,

Que um erro em tantos erros é concerto.

E, pois nesta verdade me confio

\footnotetext{
358 "Nec diuinitus interdum Venerisque sagittis / deteriore fit ut forma muliercula ametur. / Nam facit ipsa suis interdum femina factis / morigerisque modis et munde corpore culto, / ut facile insuescat <te $>$ secum degere uitam." (De Rerum Natura, IV, vv.1278-1282).
} 
(Se verdade se achar no mal que digo),

Saiba o mundo de Amor o desconcerto,

Que já coa Razão se fez amigo,

Só por não deixar culpa sem castigo. ${ }^{359}$

Continua a canção a desenvolver esse desconcerto concertado do amor, cuja cegueira se torna razão para condenar e punir a persona lírica amante. Mas esse mesmo amor que condena é a causa da culpa e do castigo; por isso, o tormento amoroso segue as leis e sem-razões do arrazoado e cego amor que, racional e legalmente, julga e pune o amante, culpado por um crime sem lei e sem razão, isto é, pelo erro (que é sempre motivo) de amar:

Já Amor fez leis, sem ter comigo algũa;

Já se tornou, de cego, arrazoado,

Só por usar comigo sem-razões.

E, se em algũa cousa o tenho errado,

Com siso, grande dor não vi nenhũa,

Nem ele deu sem erros afeições.

Mas, por usar de suas isenções,

Buscou fingidas causas por matar-me;

Que, pera derrubar-me

No abismo infernal de meu tormento,

Não foi soberbo nunca o pensamento,

Nem pretende mais alto alevantar-me

Daquilo que ele quis; e se ele ordena

Que eu pague seu ousado atrevimento,

Saiba[m] que o mesmo Amor que me condena

Me fez cair na culpa e mais na pena. ${ }^{360}$

Essa pena, com que se escreve e com que se sofre o amor, é resultado do faminto desejo pelo sumo bem que nunca se alcança, pois, embora conhecido, está inacessível no Paraíso, desde o primeiro pecado que a todos condenou. E assim é que o amor "faz perder o siso", oferecendo o perfeito impossível para aumentar a humana cobiça, enterrada no triste e escuro "abisso":

${ }_{360}^{359}$ Camões, L. de. Obra Completa, op.cit., p.303.

${ }^{360}$ Idem, ibidem. 
Destarte o sumo bem se me oferece

Ao faminto desejo, por que sinta

A perda de perdê -lo mais penosa.

Como o avaro a quem o sonho pinta

Achar tesouro grande, onde enriquece

E farta sua sede cobiçosa,

E, acordando, com fúria pressurosa,

Vai cavar o lugar onde sonhava,

Mas tudo o que buscava

Lhe converte em carvão a desventura;

Ali sua cobiça mais se apura,

Por lhe faltar aquilo que esperava:

Destarte Amor me faz perder o siso.

Porque aqueles que estão na noite escura

Nunca sentirão tanto o triste abis[s]o,

Se ignorarem o bem do Paraíso. ${ }^{361}$

O bem do Paraíso está perdido desde Adão e Eva; ele é uma "ideia" que, ao alimentar o desejo, torna o amor humano mais faminto. Preso à escuridão das coisas terrenas, esse amor vulgar e cobiçoso não pode contemplar o sumo bem, pois, para tanto, é necessário um perfeito e elevado amor que, sendo celeste, não se guia pelos enganosos sentidos numa procura cega pelo prazer do corpo. É pertinente lembrar, nesse sentido, os dois amores, ou melhor, os dois Eros acerca dos quais discorre Pausânias no Banquete platônico:

Como todo mundo sabe, não há Afrodite sem Eros. Ora, se só houvesse uma Afrodite, Eros também seria um só; mas, como há duas, será forçoso haver dois Eros. Poder-se-á negar que há duas divindades? Uma, a mais velha, nascida sem mãe, é filha de Urano, razão de ser chamada urânia ou celeste; a mais nova é filha de Zeus e de Dione, e a essa damos o apelido de pandêmia ou vulgar. Por isso, é de toda a necessidade que, havendo dois Eros, o auxiliar desta última deusa seja, com justiça, denominado vulgar, ficando para o outro o qualificativo de celeste. (Banquete, VIII, 180d-180e).

${ }^{361}$ Idem, p.305. 
Esclarece, ainda, Pausânias que o amor vulgar, oriundo da Afrodite pandêmia, é apreciado pelos "indivíduos de baixa extração", que gostam tanto de mulheres quanto de rapazes, revelando "mais amor ao corpo do que à alma, e da maneira mais estulta possível, pois só visam à realização do ato, sem pensarem sequer na maneira bela nem feia de consegui-lo. O resultado é pegarem o que a sorte lhes põe ao alcance da mão, tanto podendo ser bom como o contrário disso." (Idem, IX, 181b).

No terceiro livro dos Asolani, de Pietro Bembo, essa distinção dos dois amores, associados às duas diversas Afrodites ou Vênus, é também referida: "separado el amor 'natural' (el 'sensible' de la escolástica, ligado al matrimonio y perpetuación de la especie) del 'voluntario', se procede a distinguir en éste último el 'bello y bueno' (honesto y perteneciente a la ragione), del 'malo', 'reo' (deshonesto y perteneciente a il senso). En correspondencia con ello, se habla también de dos Venus o Reinas de Chipre". ${ }^{362}$ Mais especificamente, é assim diferenciado "il vero e celeste e immortale amore" do "falso e terrestre e mortale amore":

Quivi a niuno si cerca inganno, a niuno si fa ingiuria, a niuno si rompe fede. Nulla fuori del convenevole né si procaccia né si conciede né si desidera; e al corpo quello che è bastevole si dà, quasi un'offa a Cerbero perché no latri, e all'animo quello che più è lui richiesto si mette innanzi. Né ad alcuno s'interdice il cercar di quello, che egli ama, né ad alcun si toglie il potere a quel diletto aggiugnere, a cui egli amando s'invia. Né per acqua né per terra vi si va, né muro né tetto si sale. Né d'armati fa bisogno né di scorta né di messaggiero. Idio è tutto quello, che ciascun vede, che il disidera. Non ire, non scorni, non pentimenti, non mutazioni, non false allegrezze, non vane speranze, non dolori, non paure v'hanno luogo. Né la fortuna v'ha potere né il caso. Tutto di sicurezza, tutto di contentezza, tutto di tranquilità, tutto di felicità v’è pieno. ${ }^{363}$

O amor imortal, celeste e verdadeiro é todo segurança, contentamento, tranquilidade e felicidade, enquanto o mortal, terrestre e falso é feito de iras, insucessos, arrependimentos, mudanças, falsas alegrias, vãs esperanças, dores e temores.

\footnotetext{
${ }^{362}$ Ciordia, M. J. Amar en el Renacimiento: un estudio sobre Ficino y Abravanel, op.cit., p.135.

${ }^{363}$ Bembo, P. Gli Asolani. In: Prose della volgar lingua; Gli Asolani; Rime. A cura di Carlo Dionisotti. Milano: TEA, 1989, p.502.
} 
Na poesia lírica seiscentista, muitas vezes, esses dois amores ou essas duas Vênus são reunidos, agudamente, na amada, que é terrestre ao incitar o desejo e celeste ao mostrar-se inacessível. Nas primeiras estâncias, já citadas, do romance Amor me manda que escriba, da Fuente de Aganipe de Faria e Sousa, observamos que a persona lírica, incitada pelo amor, declara-se impossibilitada, por não ter prerrogativas de um Deus, de escrever sobre a Luz-amada que a despojou da vista. ${ }^{364}$ Contudo, nas estâncias seguintes, essa persona amante se anuncia como um segundo cego Cupido (e, por isso, não se trata de um "cego menor"), a quem deu origem aquela Luz-amada que, então revelada Albânia, é uma segunda Vênus:

6. Todavia, Albania, creo

que no soy ciego menor,

desde que tu me cegaste

con tempestad de arrebol.

7. Que si la Diosa màs bella

ciego un Cupido nos diò, bien pudo dar otro tanto

tu màs bello resplandor.

8. En Deidad me constituye mi soberana passion, si como Deidad se mira, al que Deidades mirò.

9. Si es cierto que por ti logra el Mundo dòs Venus oy, no tengo yo por incerto que oy los Cupidos son dós.

10. Si el Idalio siempre ha sido de la que en el mar nacio, de la que naciò en la tierra, yo por Cupido me doy.

11. En la tierra? Mal he dicho.

No naciste en ella, no :

Del Cielo has caido en ella, porque él solo fue tu Autor. ${ }^{365}$

\footnotetext{
${ }^{364}$ Colocar a página em que citei...

${ }^{365}$ Faria e Sousa, M. de. Fuente de Aganipe. Parte quinta, op.cit., fls.168-168v.
} 
O mundo logra, assim, duas Vênus graças a Albânia. A primeira, que nasceu no mar, é aquela chamada de urânia ou celeste, pois provém de Urano (ou do "Céu”); seu nascimento decorre de uma vingança de Crono contra seu pai, o "Céu", cujo pênis, cortado pelo filho, caiu no mar e de seu sêmem se originou Afrodite, como se lê na Teogonia de Hesíodo:

Veio com a noite o grande Céu, ao redor da terra desejando amor sobrepairou e estendeu-se a tudo. Da tocaia o filho alcançou com a mão esquerda, com a destra pegou a prodigiosa foice longa e dentada. E do pai o pênis ceifou com ímpeto e lançou-o a esmo para trás. (...) O pênis, tão logo cortando-o com o aço atirou do continente no undoso mar, aí muito boiou na planície, ao redor branca espuma da imortal carne ejaculava-se, dela uma virgem criou-se. Primeiro Citera divina atingiu, depois foi à circunfluída Chipre e saiu veneranda bela Deusa, ao redor relva crescia sob esbeltos pés. A ela Afrodite Deusa nascida de espuma e bem-coroada Citeréia apelidam homens e Deuses, porque da espuma criou-se e Citeréia porque tocou Citera, Cípria porque nassceu na undosa Chipre, e Amor-do-pênis porque saiu do pênis à luz. Eros acompanhou-a, Desejo seguiu-a belo, tão logo nasceu e foi para a grei dos Deuses. ${ }^{366}$

Essa é a Vênus, de origem celeste e nascida no mar, que, no referido romance da Fuente de Aganipe, gerou o "Cupido idálio". O outro Cupido é a persona lírica amante ("yo por Cupido me doy"), que ficou cega diante da "tempestad de arrebol" que é a divina beleza de sua amada Albânia: a outra Vênus, a nascida na terra. No entanto,

366 Teogonia, vv.176-202. Tradução utilizada: Hesíodo. Teogonia: a origem dos deuses. Estudo e tradução de Jaa Torrano. Iluminuras, 2006. 
na décima primeira estância do romance, corrige-se a procedência dessa Vênus-Albânia: sendo o Céu o seu "autor", ela não nasceu na terra, mas apenas nela caiu; portanto, é também celeste. É importante notar que quando a persona lírica se afirma Cupido, a Vênus-Albânia que lhe corresponde é a terrestre e não a celeste; dessa maneira, pode-se inferir que o cego amante é somente Eros vulgar, que não conhece o verdadeiro e imortal amor. Albânia é, enfim, Vênus terrestre e celeste: nascida na terra, é causa do Cupido vulgar; filha do Céu, não pode ser conhecida por esse cego amor, que ela própria gerou. Por esse motivo, a persona lírica, amante e poeta, não consegue escrever sobre essa amorosa confusão, e não mais a pluma lhe serve como instrumento, porque, privada aquela persona da visão, resta-lhe apenas a voz para cantar o amor com um "peregrino som":

12. Siendo tu, pues, esta, Albania; si es Amor quien más amò, yo sé bien que el mismo Idalio de amar me pide instruccion.

13. Mal, luego, le he reprehendido de que escribir me mandó; i màs quando de sus alas la pluma me dá mejor.

14. Solo el mandarme ecribir lo que veo es confusion; porque solo claramente que no veo viendo voy.

15. Pero, ya advierto me manda no escribir lo que en rigor està viendo que no veo. mas lo que ya ver me vio.

16. Sabe èl, que si bien te he visto, i me cegaste veloz, nadie como un ciego explica aquello de que cegó.

17. El sabe que te estoy viendo como quien vision soñó, i que un Ciego Aguila es grande en llamas de una Vision. 
18. Viendote estoy, ciego en ella,

con vista tan superior,

que jamás vio tanto esta Ave

en el diurno Farol.

19. Preguntole; como ciego

escribirè sin error?

Que los ciegos (me responde)

tienen por pluma la voz.

20. Que he de hazer (yo le replico)

de la pluma que me dió ?

Lo que de las cañas (dize)

hizo el Arcadio Cursor.

21. Assi pienso celebrarte

con màs peregrino son;

si, alfin, es la voz de Amante,

si el instrumento es de Amor. ${ }^{367}$

Assim como Mercúrio (o "Arcádio Cursor”) criou a lira com canas, a persona lírica utilizará a pluma das asas do "Cupido idálio" (isto é, Eros celeste) para fazer um instrumento de amor e, com sua voz de amante, celebrar sua amada Albânia. Mas para cantar esta amada, que é Vênus terrestre e celeste, não é suficiente o vulgar som que poderia produzir aquela persona amante, ou melhor, aquele Cupido apenas vulgar. Por isso, é preciso utilizar a pluma que o Cupido celeste lhe deu para compor um instrumento amoroso que, não dependendo da falha escrita de um cego amante, possa alçar, com som invulgar e peregrino, a sempre imperfeita voz terrestre à incompreensível beleza divina, pois, como afirma Ficino, o verdadeiro amor nada mais é do que um esforço, suscitado pela visão da beleza corpórea, para voar até a beleza divina. $^{368}$

A lírica amorosa seiscentista expõe, frequentemente, essa dupla face do amor, com um estilo florido e ornado que se singulariza por suas cultas e agudas flores. No poema que abre a Música do Parnaso de Botelho de Oliveira, Anarda é invocada para que dê ao "rude discurso" e ao "plectro feliz" da persona poética "cultas flores" e "doce harmonia":

\footnotetext{
${ }^{367}$ Faria e Sousa, M. de. Fuente de Aganipe. Parte quinta, op.cit., fls.168v-169.

368 "Verus enim amor nihil est aliud quam nixus quidam ad diuinam pulchritudinem euolandi, ab aspectu corporalis pulchritudinis excitatus." (De Amore, VII, 15).
} 
Invoco agora Anarda lastimado

Do venturoso, esquivo sentimento:

Que quem motiva as ânsias do tormento,

É bem que explique as queixas do cuidado.

Melhor Musa será no verso amado,

Dando para favor do sábio intento

Por Hipocrene o lagrimoso alento,

E por louro o cabelo venerado.

Se a gentil formosura em seus primores

Toda ornada de flores se avalia,

Se tem como harmonia seus candores;

Bem pode dar agora Anarda impia

A meu rude discurso cultas flores,

A meu plectro feliz doce harmonia. ${ }^{369}$

Anarda, "melhor Musa no verso amado", é aquela que motiva as ânsias do tormento, e que assim o faz como a gentil formosura cuja excelência é ser ornada de flores e cuja harmonia é sua candura ou pureza. Anarda é, enfim, ímpia, cruel. Como um perfeito sábio estoico, ela é tomada pela apatheia e não cede a nenhuma paixão; ela é a virtude, que por ser tão perfeita, mostra-se desumana. Diante dessa desumana perfeição, é conveniente à persona lírica, amante e poeta, criticá-la, pois, como vimos, desde Diógenes Laércio, tal cruel apatheia, "que designa propriamente a ausência de paixões, pode aplicar-se também ao homem mau, no sentido de que ele é insensível e não se deixa comover" (Vidas, VII, 117). Porém, em termos cristãos, Anarda é ímpia: “desprezadora da religião, profanadora de coisas sagradas" ${ }^{370}$; enquanto beleza divina, ela não se move pelo amor humano, mas ele é por ela movido.

A apatheia ímpia e virtuosa da amada, que causa justo sofrimento no amante, pecador apaixonado, também compõe o agudo amor da poesia amorosa seiscentista. $\mathrm{O}$ estilo lírico desta poesia orna, com cultas flores, aquela cruel excelência da amada. Florido e ornado, esse estilo, constituído de conceitos e elocução cultos e agudos, caracteriza um variado amor que é "labirinto sem saída", como o define um soneto

\footnotetext{
${ }^{369}$ Oliveira, M. B. de. Poesia completa: Música do Parnasso, Lira Sacra, op.cit., p.19.

370 Conforme a definição de "ímpio" de Bluteau: "Desprezador da Religiaõ. Profanador de cousas sagradas.” (Vocabulario Portuguez, \& Latino, op.cit., volume 9, verb. “impio”, p.516).
} 
atribuído a Bacelar. ${ }^{371}$ Amor que reúne e reinventa amores vários, imitando autoridades poéticas, como Petrarca e Camões, e conciliando fontes filosóficas, como a platônica, a estoica e a cristã. Estas fontes e aquelas autoridades são múltiplas, como ainda veremos neste nosso trabalho; e dessa rica multiplicidade, a lírica amorosa seiscentista faz amálgama, em cuja composição se confundem as matérias. O topos do viver-morrer, por exemplo, que discutimos neste capítulo, é também fundamental na lírica trovadoresca, como destacaremos no próximo capítulo, no qual, voltando-nos às cantigas dos trovadores e ao fin'amor, poderemos compreender melhor as finezas amorosas da poesia lírica do século XVII. E nesta poesia é que buscamos aquele amor agudo, como em labirinto sem saída coberto por cultas flores, em que só se ouve um doce e peregrino som de canto (escrito) de amor.

\footnotetext{
371 "Resiste um pouco, ó Fábio, a teu tormento, / Que Amor é labirinto sem saída / E se a Vontade se entregar vencida / Vitória sim, não seja rendimento. / Custe uma resistência o vencimento, / Que ũa beleza é menos que uma vida / $\mathrm{E}$ se o doce da causa te convida / $\mathrm{O}$ veneno que é doce é mais violento. / Não ande tão ufana a formosura, / Ache o amor oposição no brio, / Que não se arrisca menos que o sossego. / Faça o valor exame da cordura, / Que a monarquia livre do alvedrio / É grande praça para darse a um cego." (Obras Poéticas de António Barbosa Bacelar, op.cit., p.642). Esse soneto também pode ser lido no tomo IV da Fênix Renascida (op.cit., p.309).
} 


\section{Capítulo 3}

\section{As finezas amorosas do canto escrito seiscentista}

No som que ecoa na poesia amorosa seiscentista, ouve-se também a música da lírica trovadoresca. Sobre essa "música”, é preciso lembrar, como o faz Adma Muhana, que Dante, no De vulgari eloquentia, define a poesia como "fictio rhetorica musicaque posita: ficção retórica composta com música. Se pelo pensamento, diánoia, poesia e retórica se equivalem, como diz a Poética aristotélica, pelo metro e pelo ritmo, isto é, pela música, é irredutível a poesia à retórica". ${ }^{372}$ Além disso, ainda segundo as observações de Adma Muhana,

Tendo o sistema aristotélico para se pensar a poesia, desde a segunda metade do século XVI é implícito julgar por ele toda uma produção poética medieval - que desconsidera os princípios aristotélicos -, quando não acontece por sua vez desconsiderá-la com base nos mesmos. (...) [No entanto,] não é uma poesia [a trovadoresca] que se identifica pela mímesis e que, recortada pela tesoura aristotélica, se defina em oposição à retórica e em proximidade com a filosofia, excluindo a música de seus componentes principais; em vez disso, é uma poesia que se assenta na elevação da linguagem, e, nesta, a maior gala consistindo nos ornamentos de ordem sonora, tendo o verso por sua medida - e não uma poesia conceitual, nem imaginativa. ${ }^{373}$

Por isso, as especificidades da lírica trovadoresca ressoam na poesia seiscentista já repercutidas pelo "sistema aristotélico". A reverberação (menos sonora e mais conceitual) da produção poética medieval no século XVII se assenta em princípios aristotélicos, embora ainda se ouçam ecos de seu peculiar som; ou seja, escuta-se a música dos trovadores, mas com outros ouvidos. Dos ecos dessa música, interessamnos, em particular, os amorosos, porque deles é também feito o agudo amor da lírica

\footnotetext{
${ }^{372}$ Muhana, A. Nas envolturas das ficções não há participação da retórica: mera poesis est. Tese de Livre-Docência. Faculdade de Filosofia, Letras e Ciências Humanas, Universidade de São Paulo, São Paulo, 2011, p.198.

${ }^{373}$ Idem, pp.198 e 201.
} 
seiscentista. Desse modo, ao mencionar-se a poesia trovadoresca que versa sobre matéria amorosa, é pertinente recordar, de início, aquilo que se convencionou chamar "amor cortês" (devendo-se sempre ressaltar que essa expressão foi forjada apenas em fins do século XIX por Gaston Paris); assim o define, por exemplo, Segismundo Spina:

É a religião dos trovadores, um verdadeiro culto à mulher, que prevê a observância de todo um complexíssimo ritual. O conceito ovidiano de que amar é uma arte, e como tal o amor exige o conhecimento e a prática de uma preceptiva erótica, tem a sua fiel reprodução na época desse florescimento poético no sul da França. (...) Transposição do esquema social criado pelo feudalismo, o amor se tornou um "serviço" (culto) prestado pelo trovador à sua dama, como o compromisso que se estabelecia entre o senhor e o vassalo. Os amantes se comportam diante do amor, como um vassalo diante do seu suserano. Existe um serviço de amor como existe um serviço de cavalaria. $\mathrm{O}$ amante se torna um homelige da pessoa amada, ou mesmo do amor personificado; cumpre suas vontades, obedece a suas ordens, executa seus menores caprichos. (...) $\mathrm{O}$ amor consistia, então, nessa vassalagem rigorosa do trovador à dama de sua eleição, e tal arte previa a observância escrupulosa de cânones preestabelecidos. ${ }^{374}$

Desse "preceituário amoroso", Spina destaca cinco princípios: a vassalagem paciente e humilde, compreendendo quatro graus no seu aprendizado - suspirante, suplicante, namorado ou amigo e amante; a dama como supremo bem a que aspira o trovador; as virtudes cardinais em que se sustenta o amor - paciência, fidelidade, esperança, honra e discrição; a própria discrição, que é uma das maiores qualidades exigidas desse amor adulterino; e a "mesura" que, conforme André Monet, "é a moderação e o respeito constante da justa medida, implica dominação de si mesmo e vitória da vontade moral sobre as paixões". ${ }^{375}$ Daí ser, ainda de acordo com Spina, esse amor (dito "cortês") "um quadro de situações convencionais, de temas que se repetem, de motivos, de tópicos que se reproduzem (...). Em síntese: amor mais cerebral do que

\footnotetext{
${ }^{374}$ Spina, S. A lírica trovadoresca. São Paulo: Edusp, 1996, p.363.

375 Apud idem, p.392.
} 
propriamente do coração, disse Gaston Paris; um amor essencialmente convencional e mundano, diz Bossuat", 376

Esse amor, enfim, é também uma arte de amar, ainda que seus preceitos não sejam todos bem definidos. Desde Ovídio, pelo menos, busca-se ensinar a ars amatoria para a perfeita prática do amor. Como se sabe, seguindo o modelo ovidiano, André Capelão compôs, no final do século XII, seu Tractatus de amore, no qual apresenta uma “doutrina do amor" que, enquanto técnica, deve ser corretamente aprendida e cujas regras, portanto, devem ser conhecidas e aplicadas. Isso fica evidente no "prefácio" do tratado, em que o autor explicita o seu propósito a seu amigo Gautier, a quem o escrito é dedicado:

A força da indefectível afeição que sinto por ti, meu venerável amigo Gautier, insta-me a levar a teu conhecimento, de viva voz, e a te ensinar [docere] por escrito o modo como dois amantes podem preservar a integridade de seu amor bem como os meios pelos quais os que não são amados podem libertar-se das flechas que Vênus lhes enterrou no coração. (...) e a meus olhos parece mais claro que o dia o fato de que, tendo aprendido a arte de amar [docto in amoris doctrina], farás progressos mais seguros em matéria de amor. ${ }^{377}$

Para alguém se tornar docto in amoris doctrina, é necessário conhecer e respeitar as regras (regulae) da arte de amar, que são elencadas no final do livro II do tratado de Capelão. Algumas dessas 31 regras descrevem importantes características do chamado "amor cortês": o casamento não é desculpa válida para não amar; ninguém pode ligar-se a dois amores ao mesmo tempo; ninguém pode amar de verdade se a isso não for incitado pelo amor; quando o amor é divulgado, raramente dura; a conquista fácil torna o amor sem valor, a conquista difícil dá-lhe apreço; só a virtude torna alguém digno de ser amado; todo ato do amante tem como finalidade o pensamento da mulher amada; o amante não sabe recusar nada à amante; o verdadeiro amante é obcecado ininterruptamente pela imagem da mulher amada. ${ }^{378}$

\footnotetext{
${ }^{376}$ Idem, p.364.

377 Capelão, A. Tratado do amor cortês. Introdução, tradução do latim e notas de Claude Buridant; tradução de Ivone Castilho Benedetti. São Paulo: Martins Fontes, 2000, pp.1-2.

${ }^{378}$ Idem, pp.260-262.
} 
Essas (e outras) regras e características se efetuam na poesia trovadoresca, constituindo assim um amor que alguns estudiosos, seguindo a proposição (oitocentista) de Gaston Paris, costumam denominar "cortês". Não nos interessa discutir, neste momento, tal denominação, mas destacar que do mesmo modo que a própria poesia, o amor (poético) é um "construto histórico", ${ }^{379}$ elaborado tecnicamente; no caso da lírica seiscentista (mais especificamente, portuguesa), constrói-se, com técnicas retóricas e poéticas, um amor multifacetado, que recompõe agudamente outros construtos amorosos, como este que se convencionou chamar "cortês", ou melhor, aquela sua realização na lírica profana galego-portuguesa. Desse modo, o topos do viver-morrer, tão presente na poesia amorosa do século XVII e que, no capítulo anterior do nosso estudo, foi discutido, principalmente, a partir de uma perspectiva platônico-cristã, pode ser repensado com base na coita de amor, referida frequentemente em diversas cantigas galego-portuguesas (em particular, naquelas de amor e de amigo), ${ }^{380}$ como nesta composição de Martim Soares:

Senhor fremosa, pois me nom queredes

creer a cuit'an que me ten Amor,

por meu mal é que tan ben parecedes

e por meu mal vos filhei por senhor

e por meu mal tan muito ben oí

dizer de vós, e por meu mal vos vi:

pois meu mal é quanto ben vós avedes.

E pois vos vós da cuita nom nembrades, nen do afan que mi o Amor faz sofrer, por meu mal vivo máis ca vós cuidades, e por meu mal me fezo Deus nacer, e por meu mal non morri u cuidei como vos viss',e por meu mal fiquei

\footnotetext{
379 "A poesia, do mesmo modo que a retórica, mas, sobretudo, do mesmo modo que a filosofia, a história, a música, aparece como construto histórico." (Muhana, A. Nas envolturas das ficções não há participação da retórica: mera poesis est, op.cit., p.198).

${ }^{380}$ Como se sabe, no capítulo quarto da Arte de trovar, são assim diferenciadas as cantigas de amor das de amigo: "E porque algũas cantigas i há en que falam eles e elas outrossi, per én é bem de entenderdes se som d'amor, se d'amigo: porque sabede que, se eles falam na primeira cobra e elas na outra, é d'amor, porque se move a razon d'ele (como vos ante dissermos); e se elas falam na primeira cobra, é outrossi d'amigo; e se ambos falam en ũa cobra, outrossi é segundo qual deles fala na cobra primeiro." (Arte de trovar do Cancioneiro da Biblioteca Nacional de Lisboa. Introdução, edição crítica e fac-símile por Giuseppe Tavani. Lisboa: Edições Colibri, 2002, p.41).
} 
vivo, pois vós por meu mal ren non dades.

D'esta cuita en que me vós tẽedes,

en que oj'eu vivo tan sen sabor,

que farei eu, pois mi a vós non creedes?

Que farei eu, cativo pecador?

Que farei eu, vivendo sempr'assi?

Que farei eu, que mal dia naci?

Que farei eu, pois me vós non valedes?

E pois que Deus non quer que me valhades,

nem me queirades mia coita creer,

que farei eu? Por Deus, que mi o digades!

Que farei eu, se logo non morrer?

Que farei eu, se máis a viver ei?

Que farei eu, que conselho non sei?

Que farei eu, que vós desemparades? ? $^{381}$

Exemplificando com essa cantiga de Martim Soares, Adma Muhana observa que, nas cantigas de amor, a persona masculina nunca fala contra sua senhor, "objeto permanente de elogio". Isso porque,

a si mesmo atribui-se a razão do desamor da amada e a responsabilidade pela coita, quando não a Deus, que contra ele se arma. O elogio que superlativa a senhor, unidade virtuosa, é simetricamente oposto ao abatimento que a persona do amante se impõe, por espedaçado entre ações, hábitos, paixões e pensamentos desencontrados. Se tem a si como contrário, o amante aparece (ou mal aparece) como mero borrão em confronto com aquela que detém, inversamente, tão bon parecer, tão bon falar e tão bon prez. É condição do amor falar em gênero epidítico, uma vez que amar é descobrir na coisa amada a mais bela e virtuosa,

\footnotetext{
${ }^{381}$ Não havendo menção em contrário, as citações das cantigas provêm da Base de datos da Lírica Profana Galego-Portuguesa (MedDB), versión 2.3.3. Santiago de Compostela, Galicia: Centro Ramón Piñeiro para a Investigación en Humanidades. Disponível em: http://www.cirp.es/. Vale ressaltar que consultamos também outra base de dados, que oferece, além dos textos das cantigas, interessantes notas explicativas: Lopes, Graça Videira; Ferreira, Manuel Pedro et al. (2011-). Cantigas Medievais Galego Portuguesas [base de dados online]. Lisboa: Instituto de Estudos Medievais, FCSH/NOVA. Disponível em: http://cantigas.fcsh.unl.pt.
} 
enaltecendo-a sobre todas as demais. (...) É como aparece, entre tantos exemplos, na cantiga de mestria de Martim Soares (CBN 130, CA 46), na qual a dialética amorosa prodigaliza antíteses, embora um encadeamento por meio das anáforas mantenha a sucessão lógicotemporal no passo de uma andadura no mesmo lugar, enaltecendo a senhor, e, pour cause, afrontando o apaixonado. ${ }^{382}$

Entre as antíteses que a dialética amorosa prodigaliza, na referida cantiga de Martim Soares, está justamente o viver-morrer de amor, tópico muitas vezes glosado na lírica seiscentista, como já destacamos no segundo capítulo deste nosso trabalho. A persona da citada cantiga lamenta a coita, mas não culpa, em nenhum momento, a sua senhor fremosa por tal sofrimento; o mal do amante, que se origina na sua própria escolha, é o bem (ou a "unidade virtuosa") da amada, que o fez tomá-la por sua senhor. Essa coita, que é ignorada, convenientemente, por dama de tão bon prez, em vez de ser causa de anseios de morrer, como se poderia supor, é o que mantém vivo o amante, sofrendo sempre uma vida tan sen sabor. Declarando-se infeliz e pecadora, a persona lírica não sabe o que fazer: desamparada por dama tão discreta, restar-lhe-ia morrer; no entanto, viverá enquanto perdurar a coita, pois a vida do amante consiste no mal de amor ("por meu mal vivo máis ca vós cuidades").

Essa coita que é vida do amante é uma relevante fonte - e, consequentemente, um importante aspecto para a compreensão - do amor agudo da lírica seiscentista. Assim, num soneto amoroso (castelhano) da já mencionada Fuente de Aganipe, de Manuel de Faria e Sousa, somente o amar (que é um contínuo desejo, resultando sempre em tormento, de ver a beleza da amada) "chama a viver" a persona lírica:

Yo no se que destino, ô dulce, ô fiero,

me doma con Amor, ô Fortaleza;

pues solo quiero ver vuestra Belleza,

i tormento hallo solo en lo que quiero.

Yo no se deste estremo el fin que espero,

si no es fama gentil de su grandeza;

pues si de Amor me mata la fineza,

yo para amaros por vivir me muero.

\footnotetext{
${ }^{382}$ Muhana, A. Nas envolturas das ficções não há participação da retórica: mera poesis est, op.cit., pp.180-181.
} 
Mas, ô gloria esperada màs me inflame,

ô me yele esperança màs caida,

solo el amaros al vivir me llame.

I si ha de aver un hora tan perdida

en mis dias, que passe sin que os ame,

la del morir le sea preferida. ${ }^{383}$

Na tabla da "segunda centúria de sonetos amorosos" da primeira parte da Fuente de Aganipe, o próprio poeta sintetiza o assunto desse poema: "Amar es morir, i mejor morir que no amar". ${ }^{384}$ Este amor, comparado àquele da referida cantiga de Martim Soares, embora seja também coita e, por consequência, vida (sempre penosa), é, ao mesmo tempo, morte, ou melhor, um constante morrer, pois, como afirma a persona lírica do poema de Faria e Sousa, "si de Amor me mata la fineza, / yo para amaros por vivir me muero". Nesses versos, a fineza do amor, que mata, lembra aquele mal que o amor esconde, que "mata e não se vê", do soneto camoniano Busque Amor novas artes, novo engenho. ${ }^{385}$ Além disso, em outro soneto atribuído a Camões, Passo por meus trabalhos tão isento, a fineza amorosa também está associada ao amor que vai "matando tanto a tento, / Temperando a triaga co veneno". ${ }^{386}$ Nesse sentido, é importante destacar que "fineza", no século XVII, conforme a definição de Sebastián de Covarrubias Orozco no Tesoro de la Lengua Castellana o Española, "significa algunas veces agudeza, otras perfecion de la cosa, y en termino cortesano cierta galanteria, y hecho de hombre de valor y de hõrado termino", ${ }^{387}$ ou ainda, segundo Raphael Bluteau no Dicionário Português e Latino, "acçaõ com que se mostra o grande amor, que se tem a

\footnotetext{
${ }^{383}$ Faria e Sousa, M. de. Fuente de Aganipe o Rimas Varias. Parte Primera. En Madrid: por Carlos Sanchez Bravo, 1646, fol.50.

${ }^{384}$ Idem, fol.60.

385 "Busque Amor novas artes, novo engenho, / Pera matar-me, e novas esquivanças; / Que não pode tirarme as esperanças, / Que mal me tirará o que eu não tenho. / Olhai de que esperanças me mantenho! / Vede que perigosas seguranças! / Que não temo contrastes nem mudanças, / Andando em bravo mar, perdido o lenho. / Mas, conquanto não pode haver desgosto / Onde esperança falta, lá me esconde / Amor um mal, que me mata e não se vê; / Que dias há que na alma me tem posto / Um não sei quê, que nasce não sei onde, / Vem não sei como, e dói não sei porquê." (Camões, L. de. Obras completas, op.cit., p.273).

386 "Passo por meus trabalhos tão isento / De sentimento grande nem pequeno, / Que só pela vontade com que peno / Me fica Amor devendo mais tormento. / Mas vai-me Amor matando tanto a tento, / Temperando a triaga co veneno, / Que do penar a ordem desordeno, / Porque não mo consente o sofrimento. / Porém, se esta fineza o Amor [não] sente / E pagar-me meu mal com mal pretende, / Torname com prazer como ao sol neve. / Mas, se me vê cos males tão contente, / Faz-se avaro da pena, porque entende / Que, quanto mais me paga, mais me deve." (Idem, p.290).

387 Orozco, S. de C. Tesoro de la Lengua Castellana, o Española. En Madrid: por Luis Sanchez, 1611, verb. "fino", p.405.
} 
alguem. (...) acçã̃ feita com primor, com galantaria, com cortezania. (...) sutileza, destreza". ${ }^{388}$ Assim, no soneto de Faria e Sousa, a fineza amorosa remete ao fin'amor (termo que, embora não invalide o chamado "amor cortês", nos parece mais adequado à concepção amorosa da lírica trovadoresca), ressaltando a agudeza da cortesia, do galanteio e da inevitável coita: principalmente a partir de modelos da lírica camoniana, intensifica-se a antítese viver-morrer para, aproximando os contrários efeitos do amor, maravilhar e instruir os leitores.

Essa fineza, segundo as definições de Covarrubias e Bluteau, pode ser também entendida como galanteio. No século XVII, a galanteria é considerada uma arte, cujas técnicas devem ser conhecidas pelo "galã", como se verifica, em particular, na Arte de galantería de D. Francisco de Portugal, escrito que segue os moldes e visa a semelhantes propósitos da Ars amatoria de Ovídio e do De amore de Capelão. Assim, no tratado de D. Francisco de Portugal, a galanteria é colocada acima do amor e da amizade, porque reúne as qualidades de ambos sem sofrer seus vícios:

Digamos por que no se llama amor amistad. Entre estas dos cosas hay esta diferencia: que el amor es una pasión que tiene más de deseo que de placer y la amistad es una afición envergonzada o un amor envergonzado que tiene más de placer que de deseo. El amigo pertende para lo que siempre ama y el amante para lo que no puede dejar de amar. Uno cuida de sí, otro descuídase de sí. Este nombre amistad quiere decir todo común entre iguales, cosa que no se sufre entre galán y dama. Amor, su fin es unir y gozar, grosería también que se puede sufrir para propria, y no para ajena.

La galantería halló un lugar superior entre estas dos cosas, que quien dijo galán dijo un acatamiento en que está la gloria, una servidumbre en que están los mandos, un amor que nunca es deseo y una amistad que nunca es igualdad, quintas esencias del alma que no ama, adora; no pertende, sirve, y que la ponen tan lejos de la esperanza, como del esperar. ${ }^{389}$

\footnotetext{
${ }^{388}$ Bluteau, R. Vocabulario Portuguez, \& Latino, op.cit., volume 4, verb. "fineza", p.125.

389 Portugal, D. F. de. Arte de galantería. Edição e notas de José Adriano de Freitas Carvalho. Porto: Centro Inter-Universitário de História da Espiritualidade; Faculdade de Letras da Universidade do Porto, 2012, p.77.
} 
Desse modo, na noção de galanteria nota-se a persistência de alguns aspectos do fin'amor: ela não é um amor-paixão, que é sempre desejo e tem como fim a "grosseria" de "unir e gozar"; o perfeito "galã" é recatado, servil, não ama (ou deseja), mas adora, não pretende galardão algum, mas serve sem nada esperar. Esclarece ainda D. Francisco de Portugal que "galán y galantería se derivaron de gala, porque la ha de traer no sólo en lo que viste, sino en lo que piensa y en lo que dice y en lo que hace, que responde a pensamientos, palabras y obras". 390 Portanto, os vocábulos galán e galantería, derivados de gala, não se referem apenas ao "vestido curioso e de festa alegre e de regozijo", 391 pois, para ser "galã", não basta andar "vestido de gala": tal “gentil homem” também se faz por pensamentos, palavras e obras galantes.

Nos Divinos e humanos versos do mesmo D. Francisco de Portugal, nas glosas ao mote "no quiero más de vos que lo que os quiero", evidenciam-se alguns desses preceitos da galanteria que, como foi ressaltado, ecoam aqueles do fin'amor:

Es tan cuerda mi justa confianza, tanto sé respetar lo que en vos veo, que aunque siempre fue loca la esperanza, nunca ofendí la fe con el deseo.

Lo que mi amor pretende en sí lo alcanza, que es el premio mayor su mismo empleo. Cuando más quiero, cuando por vos muero, no quiero más de vós que lo que os quiero.

No me podré quejar de desamado, pues de quereros vivo satisfecho: hallo la mayor paga en mi cuidado, el mayor galardón dentro en mi pecho.

Cuanto más amo quedo más pagado, al compás de la fe crece el provecho; pues tengo en ela todo lo que espero,

\footnotetext{
${ }^{390}$ Idem, p.79.

${ }^{391}$ No Tesoro de la Lengua Castellana o Española, a palavra gala é definida como "el vestido curioso y de fiesta alegre y de regozijo. Llanamente este nõbre es Griego $\gamma \alpha \lambda \alpha$, lac, por que a la leche le damos el epicteto de blanca: y esta color es entre todas la mas alegre y regozijada, y todos los que celebreuã fiestas de plazer se vestian de blanco"; e galán é "el que anda vestido de gala, y se precia de gentil hombre: y porque los enamorados de ordinario andan muy apuestos para aficionar a sus damas, ellas los llamã sus galanes; y comũmente dezimos, Fulano es galan de tal dama." (Orozco, S. de C. Tesoro de la Lengua Castellana, o Española, op.cit., verb. "gala" e "galán", p.422).
} 
no quiero más de vos que lo que os quiero. ${ }^{392}$

A confiança do galã-amante é justa e sempre cordata, porque ele sabe respeitar o que vê na dama: a beleza (que é virtude); e embora seja louca a esperança, nunca a fé (ou o amor) se contamina com o desejo: esse perfeito amor se satisfaz em si mesmo, sendo seu maior galardão seu devoto cuidado, sem nada mais a esperar. A um tão perfeito amor corresponde a perfeição da dama, definida da seguinte maneira na Arte da galantería, fazendo lembrar aquela sempre bela e virtuosa senhor da lírica trovadoresca:

Este nombre dama es voz francesa que entre nosotros dicho sin adjectivo no solamente quiere decir señora, mas por antonomasia señora que sirve en palacio, religión en que se deshace de mujer la que la profesa, divinidad adonde el conocimiento nunca llega a voluntad y el mayor agradecimiento no pasa de cortesía, luz a que se ven como delitos las diligencias y para quien imaginaciones de ventura son desaseos de la fe, destierro del pensar y tribunal libre de clamores aun de los ojos, severidad de entendimiento que comprendiendo todo mal logra noticias que puedan obligar, mando que no se teme de ingrato, porque no busca agradecidos sujetos más al exercicio de los cuidados que a la intención, sagrado de los achaques de mala correspondencia, que no le puede faltar lo visto, justos pasos por lo divino, ídolo de los pensamientos, independencias de servicios ni premio, satisfación aplicada, que el galán triunfa en la servidumbre y la dama en sí misma por ser servida. ${ }^{393}$

A dama é elevada à condição de divindade, que não pode ser conhecida pela vontade ou pelo desejo, e sim apenas adorada pela fé. Tudo o que esse amor (ou fé amorosa) pretende, como se observa naquelas citadas glosas dos Divinos e humanos versos e neste trecho da Arte de galantería, é nada mais que seu próprio emprego, pois amar já é seu maior prêmio, triunfando o galã na servidão e a dama em si mesma por ser servida; por isso, tal amante não quer nada mais da amada do que querê-la. Querê-la significa adorá-la, respeitando aquilo que o galã-amante vê e não entende: a beleza ou

\footnotetext{
${ }^{392}$ Portugal, D. F. de. Divinos e humanos versos. Introdução e notas de Maria Lucília Gonçalves Pires. Porto: Centro Inter-Universitário de História da Espiritualidade; Faculdade de Letras da Universidade do Porto, 2012, p.144.

${ }^{393}$ Portugal, D. F. de. Arte de galantería, op.cit., pp.64-65.
} 
formosura (um composto de alma e corpo) da dama; isso porque, como afirma D. Francisco de Portugal, "lo que no se sabe medir es hermosura, lo que se mira y no se entiende, que mata haciendo amar, es un compuesto de alma y cuerpo tal cual vos le tenéis". ${ }^{394}$ Ressalta ainda D. Francisco que "la belleza hase de poseer para ornato de lo honesto, que cuando es de otra manera son muy costosos sus aplausos". 395

Essas considerações sobre a formosura ou a beleza que se encontram na Arte de galantería podem ser relacionadas, inicialmente, com a definição de amor que André Capelão apresenta no primeiro capítulo do Livro I de seu tratado De amore: "Amor est passio quaedam innata procedens ex visione et immoderata cogitatione formae alterius sexus, ob quam aliquis super omnia cupit alterius potiri amplexibus et omnia de utriusque voluntate in ipsius amplexu amoris praecepta compleri”. ${ }^{396}$ Segundo Capelão, o amor é, portanto, uma paixão inata que procede da visão e da constante "cogitação" da beleza (forma) do outro sexo e que, conquanto seja desejo de abraçar, é um desejo que respeita os preceitos do amor. Esse respeito aos amoris praecepta indica que aquela passio inata deve ser refreada para que seja moralmente adequada, mesmo porque a beleza da qual ela procede não se restringe ao belo físico, meio incapaz de instigar o amor, mas se constitui, essencialmente, pela probidade moral, pela excelência dos costumes. Isso fica evidente quando, no sexto capítulo do Livro I do Tratactus de amore, referem-se os modos para se obter o amor (qualiter amor acquiratur et quot modis). Assim, seriam cinco os meios para se fazer amar: beleza física (formae venustate), probidade dos costumes (morum probitate), extrema facilidade de elocução (copiosa sermonis facundia), grande riqueza (divitiarum abundantia) e prontidão com que se cede aos desejos (facili rei petitae concessione). No entanto, para Capelão, somente os três primeiros meios são capazes de causar o perfeito amor e, entre eles, não pode prevalecer o belo físico, pois o que se deve buscar tanto nos homens quanto nas mulheres é não somente a beleza, mas, acima de tudo, a excelência dos costumes (morum honestatem). Por isso, adverte o tratadista:

A mulher, tanto quanto o homem, não deve preocupar-se com beleza nem com elegância ou nascimento, pois "nenhuma beleza tem atrativos

\footnotetext{
${ }^{394}$ Idem, p.50.

${ }^{395}$ Idem, p.56.

396 “Amor é uma paixão natural que nasce da visão da beleza do outro sexo e da lembrança obsedante dessa beleza. Passamos a desejar, acima de tudo, estar nos braços do outro e a desejar que, nesse contato, sejam respeitados por vontade comum todos os mandamentos do amor." (Capelão, A. Tratado do amor cortês, op.cit., pp.5-6).
} 
quando faltam qualidades de alma", e só as virtudes da alma [morum probitas] conferem ao homem a verdadeira nobreza e lhe dão o esplendor da beleza. Porque, vistos sermos todos rebentos de uma mesma cepa e termos todos, naturalmente, a mesma origem, não foram a beleza nem a elegância nem mesmo a riqueza que deram origem à elite que é a nobreza nem engendraram as diferenças de classes, mas sim as qualidades morais [morum probitas]. (...) Logo, em amor só a excelência dos costumes merece ser coroada [Sola ergo probitas amoris est digna corona . $^{397}$

Nas cantigas de amor, essa probitas da senhor é frequentemente coroada junto com sua fremosura: a senhor é fremosa e também de mui bon sen, acompanhando sempre a beleza física a excelência dos costumes, como se verifica nesta cantiga de Estevan Fernandez d'Elvas:

A mia senhor fezo Deus por meu mal

$\tan$ fremosa, $\tan$ de bon sen, atal

que semelha que nunca en al cuidou;

por dar a min esta coita en que vou

sei eu que a fez El e non por al,

se m'ela con todo este ben non val.

Mui ben na fez falar e entender

sobre quantas donas El fez nacer

que semelha que nunca en al cuidou;

por dar a min esta coita en que vou

sei eu que a fez tan ben parecer,

se m'ela con tod'esto non valer.

Esta senhor que min en poder ten

fez Deus fremosa e de mui bon sen

que semelha que nunca en al cuidou;

por dar a min esta coita en que vou

sei eu que a fez, non por outra ren,

${ }^{397}$ Idem, pp.19-21. 
se m'ela con todo este ben non ven. ${ }^{398}$

A senhor, feita com perfeição por Deus, é tan fremosa e tan de bon sen que, divinamente perfeita, é causa da coita do amante, visto que ele não pode ascender a todo esse bem nem todo esse bem pode valer a um imperfeito desejo humano. A beleza e a morum probitas da senhor fazem-na superior a qualquer outra dona que Deus criou: conquanto todas as donas sejam divinas (já que todas foram feitas por Deus), o elogio que se realiza na mencionada cantiga eleva a senhor a uma perfeição humanamente inatingível, por ser fruto de um exclusivo cuidado divino, compondo um bem tão perfeito que é origem de todo mal da persona lírica amante, rendida ao poder dessa senhor perfeitamente (porque Deus a fez assim) bela e virtuosa. Tanta fremosura - que, divina, é também virtude - é constante motivo do mal de amor, pois a mesura da senhor sempre fremosa origina gram mal sem mesura, como se depreende do seguinte trecho de uma cantiga de D. Dinis:

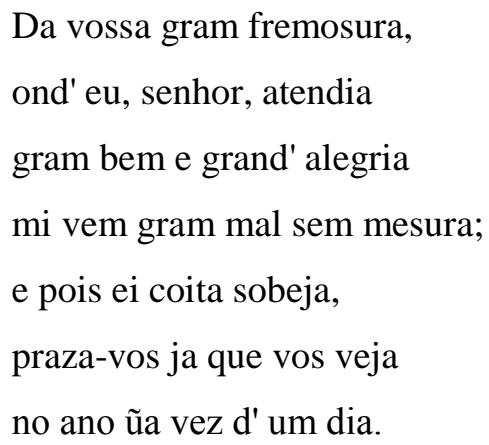

De gram fremosura (que é também bondade) se esperam o bem e a alegria, mas o que se alcança é um mal sem mesura e uma coita sobeja, não por culpa dessa beleza perfeita, e sim devido à imperfeição daquele que a deseja. Por isso, a fremosura fere aqueles olhos que a veem e não a apreendem, sendo melhor não vê-la ou só vê-la uma vez por ano. A beleza da amada é, portanto, um bem em que consiste o mal do amante. Na lírica amorosa seiscentista, essa contradição da beleza (que é um bem em si, mas um mal para o amante) fica evidente em diversos "retratos", em que o elogio das partes do corpo indica a formosura do todo, compondo-se, muitas vezes, uma dama que, embora seja bela, é fonte de sofrimento para aquele que a cobiça. Sobre esses frequentes "retratos" da poesia do século XVII, elucida Maria do Socorro Fernandes de Carvalho:

\footnotetext{
${ }^{398}$ No caso do texto dessa cantiga, adotamos a lição de Segismundo Spina: A lírica trovadoresca, op.cit., p.308.
} 
O ornato poético da beleza feminina encontra melhor expressão nos famosos retratos seiscentistas, idealização tardia da mulher petrarquista, modelo que sobrevive, embora bastante alterado no século XVII, a contar com as numerosas glosas poéticas dessa temática na Fênix Renascida, por exemplo. Na elocução dos retratos, os poetas imitam também autores modernos, particularmente as soluções poéticas dos versos de Gôngora, como os do imitado soneto Mientras por competir con tu cabello, emblemático por ornamentar um poema lírico segundo preceitos do estilo alto. Em ambos os casos de imitação dos italianos ou espanhóis, procedimento de composição muito comum é a ilustração da beleza da mulher a partir de imagens de partes do corpo, lugar de onde nascem numerosas metáforas, como as da "boca de rubi" ou do "colo de alabastro" que, de tão parafraseadas, tornaram-se signo dessa poética. ${ }^{399}$

Nesse sentido, num quarteto de um romance atribuído a Antônio da Fonseca Soares, que se encontra no sexto tomo da já mencionada compilação manuscrita de Antônio Correia Vianna das "obras poéticas" de Frei Antônio das Chagas, o colo da dama retratada é de extrema brancura (ou, em outras palavras, um "colo de alabastro") e queima, com um cristalino incêndio, a quem chega a seus "Alpes" (metáfora dos seios):

$$
\begin{aligned}
& \text { El cuello, cuya blancura } \\
& \text { ningun extremo exagera, } \\
& \text { cristalino incendio abrasa } \\
& \text { a quien a sus Alpes llega. }{ }^{400}
\end{aligned}
$$

Esse romance, identificado no manuscrito como um "retrato de una hermosa Dama, que salió airosamente adornada en una mañana de Abril”, é apenas um dos muitos retratos da poesia seiscentista. Na Fênix Renascida, há diversos outros exemplos dessa temática na produção poética dos anos Seiscentos, valendo-se destacar, como o fez Maria do Socorro Fernandes de Carvalho, o exemplar "retrato de Márcia" dito de

\footnotetext{
${ }^{399}$ Carvalho, M. S. F. de. Poesia de agudeza em Portugal, op.cit., pp.343-344.

${ }^{400}$ Obras em que se incluem Romances Liricos Castelhanos de Antonio da Fonseca Soares..., op.cit., p.232.
} 
Jerônimo Baía, ${ }^{401}$ cujo primeiro quarteto expõe o propósito do poema: "Pintar o rosto de Márcia / Com tal primor determino, / Que seja logo seu rosto / Pela pinta conhecido." Depois de feita tal "pintura" no decorrer do romance, esclarece a persona lírica no penúltimo quarteto: "Este é de Márcia o retrato, / E dirá quem o tem visto, / Que com ela o seu retrato / Se parece todo escrito.” Essa relação entre poesia e pintura, sendo uma de suas vertentes sintetizada nesses últimos versos pela noção de "retrato escrito", é bastante discutida na produção retórico-poética do século XVII. Desse modo, é importante recordar uma fonte fundamental desse debate: o ut pictura poesis horaciano.

\begin{abstract}
Vt pictura poesis; erit quae, si proprius stes, te capiat magis, et quaedam, si longius abstes; haec amat obscurum, uolet haec sub luce uideri, iudicis argutum quae non formidat acumen; haec placuit semel, haec deciens repetita placebit. ${ }^{402}$
\end{abstract}

Conforme as considerações de João Adolfo Hansen a respeito desses conhecidos versos de Horácio, é preciso ressaltar que não se afirma neles que a pintura é poesia ou que qualquer uma delas possa ser convertida na outra; o que há é uma comparação, atestada pela partícula $u t$ : "uma relação de homologia dos procedimentos retóricos ordenadores dos efeitos de estilo, não uma relação de identidade ou

\footnotetext{
401 "Pintar o rosto de Márcia / Com tal primor determino, / Que seja logo seu rosto / Pela pinta conhecido. // Anda doudo de prazer / Seu cabelo por tão lindo, / Pois mal lhe vai uma onda, / Quando outra já lhe vem vindo. // Sua testa com seus arcos / Do Turco Império castigo / Vencido tem Solimão, / Meias Luas tem vencido. // Dormidos seus olhos são, / Porém Planetas são ricos / Nunca já foram sonhados, / Bem que sempre são dormidos. // A dormir creio se lançam / Por ter de mortais, e vivos / Tão boa fama cobrado, / Nome tão grande adquirido. // Entre seus raios se mostra / O grande nariz bornido, / Por sinal que entre seus raios / Prova o nariz de aquilino. // Nas taças de suas faces / Feitas do metal mais limpo, / Como certos Reverendos, / Mistura o branco co tinto. // As perlas dos dentes alvos, / Os rubins dos beiços finos / Tem desdentado o marfim, / E a cor mais viva comido. // O passadiço da voz / Nem é neve, nem é vidro, / Nem mármore, nem marfim, / Nem cristal, mas passadiço, // Na maior força de Julho / Creio que treme de frio, / Pois tem como neve as mãos, / E os pés como neve frios. // Que nelas há dous contrários / Os meus olhos mo têm dito, / Pois sendo uma fermosura / São mais pequenas que os chispos. // No maior rigor do Inverno, / Na maior calma do Estio, / Nem tem frio, nem tem calma, / Nem tem calma, nem tem frio. // Porque de Inverno, e Verão / Sempre Primavera há sido, / Pois sempre veste de Abril, / E de Maio traz vestido. // Este é de Márcia o retrato, / E dirá quem o tem visto, / Que com ela o seu retrato / Se parece todo escrito. // Mas se em cousa alguma erro / Das que até aqui tenho dito, / À vista do tal retrato / Me retrato, e me desdigo." (Carvalho, M. S. F. de. Poesia de agudeza em Portugal, op.cit., pp.344-345).

${ }^{402}$ Epistola ad Pisones, vv.361-365. Na tradução de R. M. Rosado Fernandes, o mesmo trecho aparece da seguinte maneira: "Como a pintura é a poesia: coisas há que de perto mais te agradam e outras, se a distância estiveres. Esta quer ser vista na obscuridade e aquela à viva luz, por não recear o olhar penetrante dos seus críticos; esta, só uma vez agradou, aquela, dez vezes vista, sempre agradará" (Arte Poética, op.cit., pp.109-111).
} 
equivalência das substâncias da expressão plástica e discursiva". Como explica o mesmo Hansen:

Quando fazem a comparação, os versos propõem que há um modo específico de formulação para cada gênero e, logo, da sua apreciação, o que imediatamente implica que o ut pictura poesis é uma doutrina genérica da verossimilhança necessária em cada obra, segundo sua invenção, disposição e elocução, para que possa cumprir as três grandes funções retóricas de docere, delectare e movere, representadas nos versos citados. ${ }^{403}$

Por conseguinte, o poeta, para não ter que recear o olhar arguto de seus juízes (os leitores ou ouvintes), há de ser como um pintor perspicaz, que sabe usar convenientemente a distância (perto/longe), a claridade (clareza/obscuridade) e a frequência (uma vez/várias vezes), visando à composição de uma obra que seja, ao mesmo tempo, útil e bela.

No século XVII, as semelhanças entre a poesia e a pintura são discutidas em diversos tratados, como em Poesia e Pintura ou Pintura e Poesia, de Manuel Pires de Almeida. O tratadista afirma, por exemplo, que

simbolizam entre si [a poesia e a pintura] como irmãs gêmeas, e parecem-se tanto, que quando se escreve se pinta, e quando se pinta, se escreve. Em língua grega o mesmo é escrever que pintar, ou esculpir, e é verbo comum ao pintor e ao poeta (...). À poesia chamaram (...) pintura que fala, e à pintura, poesia muda (...). À poesia chamaram também muitos, que vem quase a ser o dito, pintura das orelhas, e à pintura poesia dos olhos. (...) E assim como o pincel imita a natureza, ações e semelhanças de homem ou de qualquer animal, ou parte da terra, ou do mar, assim a pena retrata tudo. ${ }^{404}$

Devido a essas similaridades, "infinitas vezes se unem a poesia e a pintura em mesmo sujeito e, como aponta curiosamente Paulo Lomaço, raramente se acha habilidade

\footnotetext{
${ }^{403}$ Hansen, J.A. "Ut Pictura Poesis e Verossimilhança na Doutrina do Conceito no século XVII". In: Para Segismundo Spina: Língua, Filologia, Literatura. São Paulo: Edusp; Iluminuras, 1995, pp.204-205.

${ }^{404}$ Poesia e Pintura ou Pintura e Poesia: tratado seiscentista de Manuel Pires de Almeida. Edição e introdução de Adma Muhana; tradução do latim de João Ângelo Oliva Neto. São Paulo: Fapesp; Edusp, 2002, pp.69-72.
} 
acomodada para esta que juntamente se não incline àquela". ${ }^{405}$ Daí ser conveniente à persona lírica daquele "retrato", atribuído a Jerônimo Baía na Fênix Renascida, dizer que pintará o rosto de Márcia (e não que, como se poderia supor, o descreverá), sendo seu poema um "retrato escrito" da dama.

É preciso ressaltar, contudo, que na poesia dos anos Seiscentos, "os retratos apresentam por vezes aquele mesmo sentido de singularidade, de raridade, enfim de novidade poética, condição da maravilha, usando os poetas com frequência do recurso da evidentia com esse propósito". ${ }^{406}$ Embora já tenha sido apresentada uma definição da evidentia, cabe, neste momento, mencionar outra que contribui para a compreensão dos retratos da lírica seiscentista: conforme Heinrich Lausberg, a evidentia é uma descrição "viva y detallada de un objeto mediante la enumeración de sus particularidades sensibles (reales o inventadas por la fantasía). (...) se trata de la descripción de un cuadro que, aunque movido en sus detalles, se halla contenido en el marco de una simultaneidad (más o menos relajable)". ${ }^{407}$ Desse modo, na poesia amorosa do século XVII, muitas vezes, ao retratar-se a dama, descrevem-se agudamente as partes de seu corpo, para mostrar a singularidade e raridade tanto da mulher retratada quanto de seu retrato escrito, maravilhando aqueles que o veem. Assim o faz, por exemplo, a persona lírica de um romance atribuído a Antônio Barbosa Bacelar, descrevendo a bela e rigorosa amada do cabelo aos pés:

Ora meu bem vinde cá,

Deixai melindres, dizei,

Haveis vós de dar resposta

Às minhas perguntas? Quem!

Não falais ou não ouvis,

Mas parece que dizeis

Tais podem ser as preguntas

Que o não mereçam? Quem!

É esta toda a profia,

É isto o que respondeis,

Quereis que fale somente

A ver o que digo? Quem!

\footnotetext{
${ }^{405}$ Idem, p.73.

${ }^{406}$ Carvalho, M. S. F. de. Poesia de agudeza em Portugal, op.cit., p.346.

${ }^{407}$ Lausberg, H. Manual de Retórica Literaria. Versión española de José Pérez Riesco. Tomo II. $4^{\text {a }}$ reimpresión. Madrid: Gredos, 2003, p.224
} 
Sim, ora vá: por ventura

Nesse cabelo achareis,

Entre tantos anéis de ouro,

Algũa memória? Quem!

Por ventura nessa testa,

Já que assento de amor é,

Pode também meu amor

Ter lugar bastante? Quem!

Por ventura nas capelas

Desses olhos poderei,

Já que nelas tive a morte,

Ter também jazigo? Quem!

Por ventura nas meninas

Dos mesmos olhos terei,

Entre brincos de aziviche,

Algũa firmeza? Quem!

Por ventura as sobrancelhas,

Que arcos do Céu se hão de ter,

Derramarão os dilúvios

De minhas lágrimas? Quem!

Por ventura nessas faces,

Que rosas se deixam ver,

Poderei nelas achar

Algum bem-me-queres? Quem!

Por ventura do nariz,

Que fino cristal se vê,

Poderei por cristal dele

Fazer conta algũa? Quem!

Por ventura nessa boca,

Que é rubi a toda a lei,

Terei entre tanto preço

Algũa valia? Quem!

Por ventura nesses dentes,

Que diamantes querem ser,

Terei em tanta dureza

Algũa brandura? Quem!

Por ventura na garganta, 
Que estreito de neve é,

Inda que me preca na empresa,

Terei nela entrada? Quem!

Por ventura desses peitos

O mimoso não serei,

Não haverá um deleite

Em tanta duçura? Quem!

Por ventura acabar-se-á

Em dia algum tanto desdém?

Para alcançar essas mãos

Não terei bom dedo? Quem!

Por ventura dos que tendes

Poucos pontos nesses pés,

Não me darei desses pontos

Um que tenha gosto? Quem!

Por ventura, finalmente,

Desse corpo não quereis

Que somente por segui-lo

Seja sua sombra? Quem!

Ora meu bem tendes visto

Quanto quero desta vez,

Se aborreceis ou se amais

Mandai-me dizer a quem. ${ }^{408}$

Nesse romance, há diversas agudezas que tornam singular o retrato da dama, surpreendendo os leitores ou ouvintes já habituados a essa vertente da lírica seiscentista. Assim, o poema é todo constituído de perguntas, excetuando o último quarteto, que embora sejam feitas pela persona lírica à amada, têm sua resposta ao fim de cada quarteto, mas uma resposta que intensifica a dúvida e, consequentemente, o sofrimento do amante: "Quem!”. A persona lírica elogia, seguindo a codificação convencional, as partes da beleza amada: o cabelo como "anéis de ouro", "as capelas dos olhos", "as meninas dos olhos", as sobrancelhas como "arcos do Céu", as "rosas das faces", o "nariz de fino cristal", a "boca de rubi", os dentes como "diamantes", a garganta como “estreito de neve". Contudo, o elogio é também um constante questionamento, que

\footnotetext{
${ }^{408}$ Obras poéticas de António Barbosa Bacelar, op.cit., pp.361-363.
} 
expõe o rigor da dama contrapondo-o aos desejos do amante: se os dentes, por exemplo, são diamantes (sempre belos), são ao mesmo tempo duros, levando a persona lírica a questionar: "Terei em tanta dureza / Algũa brandura?". E a dama, discreta como a senhor das cantigas de amor, não se pronuncia sobre as perguntas, ressoando apenas como ambígua resposta aquele indefinível "quem", que encerra, insistentemente, cada quarteto.

$\mathrm{Na}$ penúltima copla do romance, as partes elogiadas e disseminadas ao longo do texto se encontram, finalmente, reunidas, formando um corpo que, resultado delas, é do mesmo modo belo e rigoroso: o amante, guiado por seu desejo ("quanto quero desta vez"), só sabe seguir esse corpo perfeito, mas só pode segui-lo como sua imperfeita sombra. Portanto, a coita dessa persona lírica é fruto de seu desregrado querer, e não da beleza e virtude amadas: tal persona, agudamente indecorosa, deseja, inclusive, ser o "mimoso" 409 dos peitos da dama, para desfrutar seu doce (de)leite. No entanto, esse cúpido amante submete-se, enfim, obediente como um vassalo ante sua suserana, ao mando de sua amada, pois somente ela, cujo silêncio é fonte de todo mal e de todo bem, pode resolver essa "porfia", esclarecendo se aborrece ou se ama alguém. A ausência de respostas da dama é o sofrimento e a esperança daquela persona amante que, com seu retrato de perguntas, evidencia seu desejo de ser, "por ventura", o "quem" amado.

Com a repetição desse "quem", que ressoa como um refrão, no fim de cada quarteto do romance, é pertinente recordar aquela concepção, mencionada no começo deste capítulo, que caracteriza a lírica trovadoresca, diferenciando-a da própria poesia seiscentista: as cantigas, como sugere seu nome, são como música. Dessa forma, se no século XVII a poesia e a pintura são consideradas, nas palavras de Pires de Almeida, "irmãs gêmeas", na poética trovadoresca essa paridade não se sustenta; isso porque, conforme Adma Muhana,

na poética do trovar, desimportantes as ações, quer as organizadas quer as sucessivas, a analogia da poesia com a pintura não se firma. Sem pensamentos definidos, nítidos, nem caracteres qualificáveis em sua bondade, maldade, superioridade, inferioridade, a cantiga não é como pintura. Nela não se unificam as partes, que se mantêm desunidas e isoladas, agrupadas somente em pares espelhados, de modo tal que o

\footnotetext{
409 Segundo Bluteau, o vocábulo "mimoso" significa, entre outras coisas, "aquelle que he tratado com muito mimo" (Vocabulario Portuguez, \& Latino, op.cit., volume 5, verb. "mimoso", p.491).
} 
paralelismo léxico e conceitual se conforma ao da própria melodia. Inclusive, são sempre as cantigas de reduzidas dimensões, já que, quando extensas, suportam a dilatação do tempo; por não serem épicas, nem trágicas, as cantigas recordam epigramas em sua concentração afetiva. Não há triunfos aqui, mas pequenos cataclismos. Em vez de lidas e inteligidas, são peças líricas destinadas a ser cantadas e repercutidas, como música - a mesma música que Aristóteles excluíra da sua Poética. ${ }^{410}$

Entretanto, ainda que os poemas seiscentistas não soem como música, sendo destinados, principalmente, à leitura e à intelecção, mostram-se também relevantes seus aspectos sonoros, que muito devem às cantigas dos trovadores. A poesia do século XVII, aproximando-se da pintura, está mais voltada para os olhos, mas são ainda fundamentais os ouvidos para a compreensão dessa lírica, cujo som repercute agudo aquele do trovar. Dessa maneira, o repetido "quem" daquele citado romance, avalizado pela autoridade poética de Bacelar, pode ser comparado (e não confundido) com o "refrão", procedimento poético-musical utilizado frequentemente nas cantigas e definido por Segismundo Spina da seguinte forma:

O refrão é um fragmento poético no corpo da composição, ao qual regressa constantemente o coro (às vezes cantado por um solista), entre a execução de uma estrofe e outra. (É o estribilho, ital. ritornello). $\mathrm{Na}$ sua forma primitiva original o refrão não teria relação lógica com o conteúdo poético. Não tardou que esta articulação semântica se estabelecesse, e a partir século XI-II (sic), nos rondeaux, nos virelis, vamos encontrá-lo como prelúdio da canção, com indicação da melodia. A canção inicia-se com o refrão e termina com ele. O refrão é expediente que caracteriza a poesia popular, folclórica. ${ }^{411}$

Contudo, é preciso ressaltar que essa busca de uma "relação lógica" do refrão (mesmo que em sua "forma primitiva original") com o "conteúdo poético" se pauta por critérios que não condizem com a poética do trovar e sua correspondente lírica, cuja

\footnotetext{
${ }^{410}$ Muhana, A. Nas envolturas das ficções não há participação da retórica: mera poesis est, op.cit., p.184.

${ }^{411}$ Spina, S. A lírica trovadoresca, op.cit., p.400.
} 
sonoridade prescinde, por vezes, de uma lógica conceitual. Como observa Adma Muhana, as cantigas de refrão do século XIII,

baseadas numa estrutura paralelística, que se faz por múltiplos modos, nas menores e nas maiores porções das cantigas, aparentam uma mistura de simplicidade e artifício, de que se desconfia.(...) Estudos consagrados têm justificado a estrutura paralelística de tantas das cantigas de amigo (...) como sendo uma demonstração de sua raiz "primitiva", haja vista a presença constante de procedimentos de repetição nas poesias orientais e populares. Justificada, assim, a repetição paralelística, a ela é dado um lugar singelo, atrelado a necessidades métricas e rímicas, melhor dizendo, melódicas das cantigas; a própria designação de "cantigas" apontando para a deficiência de um caráter poético propriamente dito, adquirido, segundo a mesma concepção, apenas aquando da independência do texto em relação à música, por volta do século XV. ${ }^{412}$

Mesmo após o século XV, essa independência do texto em relação à música, embora seja predominante, não é opinião unânime. Como aponta a mesma Adma Muhana, em outro estudo, na Música do Parnaso de Botelho de Oliveira, por exemplo, identifica-se, a começar pelo título da obra, a poesia lírica com sua arte "irmã" e "gêmea", que não é a pintura (como é mais comum na produção retórico-poética seiscentista), e sim a música. Essa peculiaridade da poética de Botelho de Oliveira decorre, dentre outras coisas, da imitação de Giambattista Marino, elogiado pelo próprio poeta da Música do Parnaso na dedicatória de sua obra, sendo qualificado como “delicioso Marino". 413 Assim, no principal poema mariniano, leem-se os seguintes versos: "Musica e Poesia son due sorelle / ristoratrici del'afflitte genti, / de' rei pensier le torbide procelle / con liete rime a serenar possenti." (Adone, canto sétimo, $1^{\mathrm{a}}$ oitava). Botelho de Oliveira, partilhando dessa concepção de Marino, define a poesia como "um

\footnotetext{
${ }^{412}$ Muhana, A. Nas envolturas das ficções não há participação da retórica: mera poesis est, op.cit., p.167-168.

${ }^{413}$ Sobre a importância de Marino na poesia de Botelho de Oliveira, veja-se o estudo de Carmelina Magnavita Rodrigues de Almeida: O Marinismo de Botelho. Tese apresentada ao Instituto de Letras da Universidade Federal da Bahia para concurso de Professor Assistente do Departamento de Letras Românicas. Salvador, 1975.
} 
canto poético, ligando-se as vozes com certas medidas para consonância do metro" (essa definição encontra-se no "prólogo" da Música do Parnaso). ${ }^{414}$

Privilegiando a sonoridade da poesia, tal "canto poético", entoado pelo "plectro doce e fino" de Botelho de Oliveira, ressoa em diversas composições, especialmente na décima intitulada "Eco de Anarda". Estando essa décima já devidamente analisada por Adma Muhana, ${ }^{415}$ é válido, ainda assim, reproduzir seu texto, para que sua música ecoe, por si só, nos ouvidos de quem a lê ou nos olhos de quem a ouve:

Entre males desvelados,

Entre desvelos constantes,

Entre constâncias amantes,

Entre amores castigados,

Entre castigos chorados,

E choros, que o peito guarda,

Chamo sempre a bela Anarda;

E logo a meu mal, fiel,

Eco de Anarda cruel

Só responde ao peito que arda.

Mas essa noção de poesia como canto poético, que se baseia "na materialidade sonora das palavras e sua composição eufônica", não predomina no século XVII. Isso porque, a produção retórico-poética seiscentista está “centrada principalmente na representação conceitual por meio de palavras”. Seguindo as lições da Poética de Aristóteles, a concepção mais corrente de poesia, entre os preceptistas e poetas dos anos Seiscentos, não se funda na metrificação e no ritmo: exclui-se a música da estrutura poética essencial, pois, conforme a preceptiva aristotélica, "embora seja um 'ornamento' maior da poesia trágica, a música permanece ornamento, ou seja, acidente, não substância". ${ }^{416}$ No século XVII, enfim, não é comum definir-se a poesia pela sonoridade, e sim pela imitação.

A concepção de poesia como representação conceitual por meio de palavras, e não como canto, evidencia-se, por exemplo, quando Faria e Sousa, ao comentar a canção camoniana Manda-me amor que cante docemente, mais especificamente sua

${ }^{414}$ Cf. Muhana, A. "Introdução". In: Poesia completa: Música do Parnasso, Lira Sacra, op.cit., pp. XLVIII-XLIX.

${ }_{415}$ Idem, pp.LXI-LXII.

${ }^{416}$ Idem, pp.LI-LII. 
primeira estância, ${ }^{417}$ identifica, frequentemente e sem qualquer ressalva, "cantar" e “escrever”; na verdade, nota-se um predomínio do escrever sobre o cantar. Para melhor se compreender o comentário de Faria e Sousa, é válido transcrever a primeira estância da referida canção dita de Camões:

Manda-me Amor que cante docemente

O que ele já em minha alma tem impresso,

Com pressuposto de desabafar-me,

E, por que com meu mal seja contente,

Diz que ser de tão lindos olhos preso,

Cantá-los bastaria a contentar-me.

Este excelente modo de enganar-me

Tomara eu só de Amor por interesse,

Se não se arrependesse,

Com a pena o engenho escurecendo.

Porém a mais me atrevo,

Em virtude do gesto de que escrevo;

E se é mais o que canto que o que entendo,

Invoco o lindo aspeito,

Que pode mais que Amor em meu defeito. ${ }^{418}$

Comentando o sétimo, o oitavo e o nono versos dessa composição ("Este excelente modo de enganar-me / Tomara eu só de Amor por interesse, / Se não se arrependesse"), Faria e Sousa esclarece que o amor manda que o poeta escreva para aliviar suas penas, pois o dizê-las parece consolo, sendo que o poeta tomaria por bom partido do amor "este modo excelente de enganar", se o amor não se arrependesse de concedê-lo; "porque quando quiere dezir, escrivir, ó cantar estas penas amorosas, con ellas le escurece èl el ingenio de tal suerte que no las puede cantar, escrivir, ó dezir: con

\footnotetext{
${ }^{417}$ Preferimos, principalmente por se tratar de uma "canção", o termo "estância" a "estrofe", por exemplo, porque, conforme uma das acepções apresentadas por Bluteau, estância é "termo da Poesia Portugueza, \& Castelhana. He huma parte da cançaõ, dentro da qual há todas as consoantes, que pede a cançaõ, cuja estancia he. E quaes forem as consoantes da primeira Estancia, taes haõ de ser nas mais, tirado o remate, que será das que quizerem. Podem ser as estancias, quantas o Poeta quizer, posto que de ordinario naó passaõ de dez, ou de doze. Em cada cançaõ há de haver Estancias, \& Remate; indaque algumas vezes naõ tem a cançaõ outro remate que a ultima Estancia." (Vocabulario Portuguez, \& Latino, op.cit., volume 3, verb. "estancia", p.308.

${ }^{418}$ Camões, L. de. Obras completas, op.cit., p.314.
} 
que por una parte le viene el Amor a negar lo que por otra le concede". ${ }^{419}$ Nesse comentário, portanto, são identificadas as ações de "cantar", "escrever" e "dizer", o que fica patente na sua enumeração ao se empregar a conjunção “ou”. Essa confusão entre “cantar" e "escrever", tendendo-se à submissão do canto à escrita, mostra-se ainda mais evidente quando o comentador seiscentista da lírica camoniana discorre sobre o antepenúltimo verso ("E se é mais o que canto que o que entendo") dessa citada primeira estância da canção, visto que ele faz uma alteração bastante significativa, e sem qualquer explicação, ao referir dito verso: "E se he mays o que escrevo que o que entendo". ${ }^{420} \mathrm{O}$ "canto" é, desse modo, substituído pelo "escrevo", como se fossem a mesma coisa, ou melhor, como se apenas se pudesse cantar em poesia escrevendo-se, isto é, fazendo-se uma "representação conceitual por meio de palavras", e não materializando o conceito pela sonoridade.

Nesse sentido, imitando Camões (já que a poesia se define principalmente pela imitação, e não pela música), há um soneto do Faria e Sousa poeta cujo primeiro verso retoma, claramente, aquele verso, também inicial, da mencionada canção Manda-me amor que cante docemente; soneto esse em que o cantar é somente um conceito escrito, ainda que estejam sempre presentes recursos sonoros:

Mandame Amor que cante brandamente, poys brandamente chego a ser amado: sey que nelle nam he termo forçado que delle escreva sô quem delle sente.

A dor mitiga hum suspirar doente; cantando o caminhante vay, cansado; canta o preso que está com maes cuidado: he, porém, o seu cantar differente.

E neste meu ordena o meu destino que imite o de Ave triste em seco ramo, onde cantando geme de contino.

Bem como ella suspende ao Peregrino, se assi canto a quem me ama, e a quem amo, pàra suspenso a ouvirme o gram Menino. ${ }^{421}$

\footnotetext{
${ }^{419}$ Rimas Varias de Luis de Camoens... Comentadas por Manuel de Faria y Sousa. Segunda Parte, op.cit., p.51.

${ }^{420}$ Idem, ibidem.

${ }^{421}$ Faria e Sousa, M. de. Fuente de Aganipe o Rimas Varias. Parte Primera, op.cit., p.120.
} 
Observa-se nesse poema da Fuente de Aganipe que o canto é um conceito desenvolvido por comparação, mas não materializado como na décima "Eco de Anarda" de Botelho de Oliveira: no soneto, o cantar da persona lírica é como aquele da ave triste em seco ramo, sem com ele se confundir; já na décima, o próprio canto da persona, cujo pathos melódico materializa o penar de amor, se faz eco de Anarda. Assim, na composição de Faria e Sousa, o cantar representa o escrever, e se escreve à imitação de como se canta, pois a poesia não é música nem "canto poético", ela é imitação: no caso, imita-se por escrito o canto da triste ave, ou melhor, desenvolve-se seu conceito, porém se evidencia que as palavras do poema não realizam tal som, tomando-se a sonoridade como acidente, e não como substância.

Dessa forma, é fundamental o primeiro verso do soneto para se compreender em que consiste esse canto brando que o amor impõe à persona lírica. Como já mencionado, esse verso inicial retoma aquele da canção camoniana, com uma única mudança: substitui-se "docemente" por "brandamente". Comentando Faria e Sousa, em particular, o trecho "que cante docemente" da composição atribuída a Camões, faz dura crítica aos "modernos versificadores":

\begin{abstract}
Esto, parece, no manda el Amor a los modernos versificadores que se imaginan Poetas; porque oy no ay uno (en España digo) que cante dulcemente, si no agriamente; eligiendo vozes, colocaciones, terminos, redundancias, y asperezas que hostigan a todo oído cuerdo: y a esto llaman ellos lo brillante, y lo acendrado, y lo sublime; añadiendo que los antiguos estavan mal informados. $\mathrm{O}$ ignorancia crassa! ${ }^{422}$
\end{abstract}

O doce canto camoniano é, dessa maneira, aquele em que não há redundâncias e asperezas, tão presentes nas agres composições dos versificadores modernos (que não merecem a designação de poetas). Do mesmo modo, pode-se estender esse comentário ao "cantar brandamente" do soneto da Fuente de Aganipe: brando é o canto que não incomoda a ouvidos prudentes, mas que soa ameno e aprazível, conquanto por vezes triste. Além disso, o amante canta conforme o amor: amada brandamente (sendo que "brando" pode ser compreendido tanto como "suave", "afável" quanto como "fraco",

\footnotetext{
${ }^{422}$ Rimas Varias de Luis de Camoens... Comentadas por Manuel de Faria y Sousa. Segunda Parte, op.cit., p.50.
} 
"mole"), à persona lírica cabe gemer continuamente, como uma ave triste pousada num ramo seco e cuja brandura do canto faz parar, suspenso, até mesmo o Cupido. Contudo, também se canta ou se escreve em virtude da beleza amada, superior aos mandos e desmandos do próprio amor; a ela se destina todo canto ou escrito amante. Isso fíca evidente no comentário de Faria e Sousa sobre os seguintes versos da referida canção camoniana: "Porém a mais me atrevo, / Em virtude do gesto de que escrevo". Afirma, então, o comentador acerca dessa, segundo ele, "excelente cláusula":

Dize assi: Pero aunque el tormento me perturba el Ingenio, como el Amor pretende, yo he de escrivir a su pesar mis amorosas penas, y su motivo, porque escrivo, no en virtude de mi Ingenio, si no en virtude de la hermosura de que escrivo: y si lo que quiero escrivir excede con gran ventaja a mi entendimiento, invocarè, para escrivirlo, aquella rara Hermosura que en mis defetos puede más q̃ el mismo Amor, que mandandome cantar me escurece el Ingenio porque no cante. ${ }^{423}$

É interessante notar, inicialmente, que embora no primeiro verso da canção camoniana o amor mande a persona lírica "cantar", o que é reafirmado no final do comentário de Faria e Sousa acima mencionado ("que mandandome cantar me escurece el Ingenio porque no cante"), utiliza o comentador, sem ressalvas, o verbo "escrever", mostrando, novamente, que o canto é entendido como poema escrito. E para escrever o que almeja (a formosura da amada), a persona lírica não pode recorrer ao amor que, mandando-a cantar (ou escrever) a perfeição amada, que excede ao humano entendimento, obscurece seu engenho para que não cante (ou escreva), pois os defeitos desse engenho apenas naquela rara formosura podem se sanar. A escrita do amante, portanto, decorre e depende sempre da beleza amada, e na participação desta perfeita formosura consiste toda tristeza ou alegria do escrever ou cantar de amor. Tal noção também está presente na lírica galego-portuguesa, mas nessa poesia, como já foi ressaltado, o canto é sua própria realização sonora, ou seja, é, além de texto escrito, música. Isso se verifica, por exemplo, na seguinte cantiga de refrão de Airas Nunes:

Amor faz a mim amar tal senhor, mais fremosa de quantas hoj'eu sei,

${ }^{423}$ Idem, p.51. 
e faz-m'alegre e faz-me trobador

cuidand'em bem sempr'; e mais vos direi:

$\mathrm{u}$ se pararom de trobar,

trob'eu e nom per antolhança,

mais por que sei mui lealmente amar.

Pois mim amor nom quer leixar

e dá-m'esforç'e asperança,

mal venh'a quem se del desasperar!

Ca per amor cuid'eu mais a valer;

e os que del desasperados som

nom podem nunca nẽum bem haver,

nem fazer bem. E per esta razom,

com amor quero-me alegrar;

e quem tristur'ou mal andança

quer, nom lhe dê Deus al, pois s'en pagar.

Pois mim amor nom quer leixar

e dá-m'esforç'e asperança,

mal venh'a quem se del desasperar!

Cousecem mim os que amor nom ham

e nom cousecem si, vedes que mal!

Ca trob'e canto por senhor, de pram,

que sobre quantas hoj'eu sei mais val

de beldad'e de bem falar,

e é cousida, sem dultança.

Atal am'eu e por seu quer'andar.

Pois mim amor nom quer leixar

e dá-m'esforç'e asperança

mal venh'a quem se del desasperar! $!^{424}$

\footnotetext{
${ }^{424}$ Para o texto dessa cantiga, preferimos adotar a lição da base de dados Cantigas Medievais Galego Portuguesas [base de dados online], op.cit. Como explicam os editores, "a composição, que é transcrita duas vezes pelos apógrafos italianos (em B 873/ V 457 e B 885bis/ V 469), apresenta variantes muito significativas entre as duas transcrições, o que tem originado variações igualmente significativas na suas várias edições contemporâneas. O editor principal do trovador, Giuseppe Tavani, seguindo a abordagem tradicional, optou por reconstruí-la a partir da junção crítica das duas transcrições, e o mesmo fazemos nós, embora alterando a ordem que propõe para as estrofes".
} 
Nessa composição, o trovar, à semelhança do cantar ou do escrever daquela canção camoniana e do soneto de Faria e Sousa, decorre do amor, que faz a persona da cantiga amar a senhor considerada, evidentemente, a mais fremosa de quantas há. Esse amor, diferentemente do que se observa com frequência na lírica trovadoresca, não é motivo de coita, mas de alegria, fazendo com que aquela persona trove sem nenhuma ambição, porque alegremente amante, sabe mui lealmente amar. E aqueles que não têm esperanças no amor nunca poderão ter ou fazer qualquer bem, por isso, ainda que sem o galardão desejado, é preciso alegrar-se tão somente com o próprio amar. Quanto àqueles desesperados, já que querem tristeza ou infelicidade (tristur'ou mal andança), é justo que tristes sejam e que trovem nada além da coita. Enfim, pouco importa à persona lírica a crítica daqueles que não amam, pois o seu trovar e cantar se alegra e se basta na senhor a quem ama e por quem trova e canta: a mais bela, eloquente e sensata senhor, que sobre todas as outras é a que mais val. Daí cantar no refrão essa persona amante que o amor não quer deixá-la, dando-lhe força e esperança, e que sofram aqueles que se desesperarem de amor.

Tal desespero amoroso pode provir daquilo que já foi discutido neste capítulo do trabalho: o amante está sempre aquém da beleza e virtudes amadas; imperfeito, ele não pode apreender nem exprimir a perfeição que ama, mas lhe cabendo enaltecer sempre a amada, superior a todas outras damas, esse conflito causa-lhe sofrimento ou uma desesperança no próprio amor. Nesse sentido, ainda nos comentários de Faria e Sousa àquela canção atribuída a Camões, Manda-me Amor que cante docemente, lê-se a seguinte explicação a respeito do verso "E se é mais o que canto que o que entendo" (cuja palavra "canto", como já foi destacado e debatido, é substituída pelo comentador, ao referir tal verso, por “escrevo"):

Confiesa que es menor su Ingenio, que el assunto que toma para cantarle; y este es la Hermosura de su Querida, y las amorosas penas que èl padece por ella; porque ella es divina, y èl es humano: y assi como no puede cantar esta Hermosura por excessivamente grande, tambien no puede cantar el amoroso tormento por ella padecido, por ser èl igual a ella. ${ }^{425}$

\footnotetext{
${ }^{425}$ Rimas Varias de Luis de Camoens... Comentadas por Manuel de Faria y Sousa. Segunda Parte, op.cit., p.51.
} 
Embora ao citar o verso Faria e Sousa tenha trocado o "canto" pelo "escrevo", ao comentá-lo, utiliza somente o verbo "cantar", o que indica, mais uma vez, que o canto na produção retórico-poética seiscentista é tomado, mais frequentemente, como imitação escrita, e não como música. Escrevendo é que a persona lírica da composição camoniana tenta cantar um assunto que excede ao seu humano engenho: a formosura divina de sua "querida" e as penas amorosas por ele padecidas. Entretanto, se não bastasse não poder cantar essa formosura “excessivamente grande", não é capaz, engenho tão pequeno, de cantar nem mesmo o tormento amoroso, pois este é igual àquela, sendo, portanto, igualmente grande.

Assim, o canto de amor na lírica amorosa seiscentista é, mais comumente, uma imitação escrita que, conquanto explorando aspectos sonoros, desenvolve conceitos agudos menos pela sonoridade do que pela lógica filosófica, à exceção de poetas como Botelho de Oliveira, para quem a poesia é "canto poético". Contudo, ainda que no século XVII a preceptiva e a produção poéticas se foquem mais no conceito do que no som, a música do trovar ainda ressoa, ao menos conceitualmente, nos poemas seiscentistas, nos quais, na maior parte das vezes, o canto não se materializa mais como música, mas se representa em imitações escritas. E a principal matéria dos cantos amorosos seiscentistas é, evidentemente, o amor. Posto que não seja o fin 'amor, o amor poético nos anos Seiscentos pode ser considerado também uma arte de amar, no sentido de ser elaborado tecnicamente e seguir preceitos (mesmo que implícitos). Esses preceitos amorosos não estão definidos em tratados específicos, porém se realizam e se cristalizam na própria produção retórico-poética do século XVII. E na preceptiva daquele fin'amor ou, para alguns, daquele "amor cortês", pode-se buscar, como ficou demonstrado, um aspecto fundamental da doutrina amorosa seiscentista: na beleza e na virtude perfeitas da amada se origina, e para elas está sempre voltado, o imperfeito desejo do amante, cujo canto, convencional, é constante elogio daquilo que se vê e não se apreende, daquilo que se ama e não se alcança, restando ou a alegria do canto em si ou o sofrimento do desejo que nunca se realiza. Isso porque, a engenhos humanos, é dado cantar apenas amores igualmente humanos, para os quais não há fim além da morte.

Morrer de amor é também convenção na lírica amorosa do século XVII. Nesta poesia, encontram-se diversos personagens que morrem por muito amar, destacando-se Lídia e Armido, cujas "saudades” foram cantadas repetidas vezes. Na Fênix Renascida, por exemplo, há três longos poemas, em oitavas, intitulados Saudades de Lydia, e 
Armido. O primeiro deles, qualificado como um "canto heroico", teria sido composto "por um Anônimo", ${ }^{426}$ mas que na Biblioteca Lusitana é atribuído a Fr. Manoel de São José, ${ }^{427}$ o segundo, "pelo Doutor Antônio Barbosa Bacelar"; ${ }^{428}$ e o terceiro, "por um Anônimo, que dizem é o Doutor Antônio Barbosa Bacelar". ${ }^{429}$ O caráter de Lídia, a quem foi "mortal doença o amor mais fino", sintetiza-o um soneto ("epitáfio na sepultura de Lídia") que, composto “por um anônimo”, é colocado logo após aquelas segundas Saudades, atribuídas a Bacelar, no primeiro tomo da Fênix Renascida:

Esta, que ves, errante peregrino,

Urna funesta em marmore erigida,

He sepulchro horroroso de huma vida

Morta ás mãos ou da Parca, ou do destino:

Foylhe mortal doença o amor mais fino

O querer bem lhe foy fero homicida;

Se fosse, como quiz, taõ bem querida,

O tempo contaría Nestorino:

Lydia jaz aqui, Lydia desgraçada,

Lydia aquelle de amor raro portento.

Mas ah naõ cuides, naõ, que sepultada

Entre as cinzas está do esquecimento,

Está viva Lydia, ainda que enterrada,

Que inda em seu peito amor infunde alento. ${ }^{430}$

Os infortúnios amorosos de Lídia, "aquelle de amor raro portento", e de Armido são cantados, além das já mencionadas que se encontram na Fênix Renascida, por outras Saudades, como aquelas que, também publicadas no século XVIII, são ditas

\footnotetext{
${ }^{426}$ A Fenix Renascida. Tomo I. $2^{\mathrm{a}}$ impressão (1746), op.cit., p.32.

${ }^{427}$ De acordo com Diogo Barbosa Machado, Fr. Manoel de São José era "natural de Lisboa filho de Roque Montez, e Anna Monteira Erimita de Santo Agostinho, cujo instituto professou no Convento patrio de N. Senhora da Graça a 12 de junho de 1633. onde floreceo com enveja dos seus condiscipulos nas sciencias escolasticas até jubilar no magisterio dellas. Foy excellente humanista, e discretissimo Poeta de cuja veya ainda se conservaõ elegantes monumentos merecendo entre todos a primazia aquelle canto que consta de 135. oitavas intitulado Saudades de Lidia, e Armido. Começa Era tempo, em que pallido retrata / Seus ardores o Sol na Thetis fria, \&c. Sahio impresso no Tom. I. da Fenix renascida, ou obras poeticas dos mayores engenhos Portuguezes." (Bibliotheca Lusitana. Tomo III. Lisboa: na Officina de Ignacio Rodrigues, 1752, pp.290-291).

${ }^{428}$ A Fenix Renascida. Tomo I. $2^{\mathrm{a}}$ impressão (1746), op.cit., p.77.

${ }^{429}$ A Fenix Renascida. Tomo II. $2^{\mathrm{a}}$ impressão (1746), op.cit., p.33.

${ }^{430}$ A Fenix Renascida. Tomo I. $2^{\mathrm{a}}$ impressão (1746), op.cit., p.91.
} 
de Crispim Amado Correa de Mattos, conhecido como "o poeta cortês", 431 e aquelas manuscritas, atribuídas a Bernardo Vieira Ravasco no quinto tomo de uma Miscelânea Poética setecentista, compilada pelo já referido Antônio Correia Vianna. ${ }^{432}$ E são estas últimas Saudades de Lídia e Armido, compostas por 158 oitavas, que mais nos interessam, ${ }^{433}$ principalmente porque nelas é cantado, de forma exemplar, o agudo amor da lírica seiscentista. Além disso, elas teriam sido compostas por Bernardo Ravasco que, muitas vezes deixado à sombra de seu ilustre irmão Padre Antônio Vieira, foi, nas palavras de Diogo Barbosa Machado, um poeta com "natural genio para a Poezia que practicou com tanta felicidade que os seus versos eraõ conhecidos pela elegancia do metro, e fineza dos pensamentos, sem que tivessem o seu nome". ${ }^{434}$ Com metro elegante e finos pensamentos se cantam tais Saudades de Lídia e Armido que, compiladas por Correia Vianna e ditas de Bernardo Ravasco, podem recuperar o nome do poeta não apenas como "Secretário do Estado do Brasil" e irmão do "insigne Padre Vieira", mas também como importante auctoritas da poesia amorosa do século XVII. ${ }^{435}$ A escassez da obra poética preservada ou conhecida de Bernardo Ravasco é afirmada, por exemplo, por Varnhagen que, em seu Florilégio da Poesia Brasileira, reportando-se à notícia referida na Biblioteca Lusitana de que Inácio Barbosa Machado (irmão do próprio Diogo Barbosa Machado) teria visto na Bahia quatro volumes manuscritos do poeta, lamenta: "infelizmente não chegaram a nosso conhecimento senão algumas poesias insignificantes em castelhano". ${ }^{436}$ Além das três décimas em castelhano, $A$ Senhora D. Isabel Princeza de Portugal havendo morto em Salvaterra hum javali com hum tiro, publicadas na Fênix Renascida, ${ }^{437}$ pouco se conhece da poesia de Ravasco, cujos versos, conforme a mencionada observação de Diogo Barbosa Machado, teriam

\footnotetext{
${ }^{431}$ Saudades de Lidia, e Armido... / Por Crispim Amado Correa de Mattos, / Chamado vulgarmente / O Poeta Cortez. Lisboa: Na Officina de Pedro Ferreira, Impressor da Augustissima Rainha Nossa Senhora, 1759.

${ }^{432}$ Miscelanea Poetica / que comprehende / o que na seguinte página se declára. Tomo $=5^{\circ}$. Junto tudo neste volume, destribuîdo, e escrito / Por Antonio Correya Vianna / Lisboa $=1784=$. Lisboa: Biblioteca da Ajuda, Ms. 49-III-65, pp.173-256.

${ }^{433}$ Saudades / de / Lidia, e Armido // Expostas na figura de Ella ficar saudosa / e magoada em terra, por Elle se ausentar / embarcando em huma Armada \& ${ }^{a} / /$ Compostas / Por Bernardo Vieira Ravasco / Irmão do grde. Pe. Ant. ${ }^{\circ}$ Vieyra / da extincta Companhia de Iesus.

${ }^{434}$ Bibliotheca Lusitana. Tomo I. Lisboa Occidental: Na Officina de Antonio Isidoro da Fonseca, 1741, p. 538

${ }_{435}$ Por esses motivos, e por nunca terem sido publicadas, transcrevemos, a partir do citado manuscrito de Correia Vianna, essas Saudades de Lídia e Armido, compostas, supostamente, por Bernardo Vieira Ravasco e que podem ser lidas, integralmente, no "anexo" desta tese.

${ }^{436}$ Varnhagen, F. A. de. Florilegio da Poesia Brazileira. Tomo I. Lisboa: Imprensa Nacional, 1850, p.133.

${ }^{437}$ A Fenix Renascida. Tomo V. $2^{\mathrm{a}}$ impressão (1746), op.cit., pp.270-271.
} 
circulado sem que tivessem seu nome. ${ }^{438}$ Mesmo na produção retórico-poética seiscentista, é o "irmão do Padre Antônio Vieira" por esse epíteto conhecido e pelo ofício que exerceu de "Secretário do Estado do Brasil", como se verifica no soneto que à sua morte dedicou Manuel Botelho de Oliveira. ${ }^{439}$ À sombra de seu "reverendo" irmão, é também que se trata da morte de Bernardo Ravasco, que teria ocorrido, segundo Sebastião da Rocha Pitta, ${ }^{440}$ um dia após (ou, conforme a Biblioteca Lusitana, ${ }^{441}$ dois dias após) à do Padre Vieira e devido à mesma enfermidade. ${ }^{442}$ Enfim, como destaca Pedro Puntoni:

O leitor dos papéis antigos do século XVII, guardados nos arquivos do Brasil ou de Portugal, cada vez que se depara com o nome de Bernardo ou uma referência a seus feitos, nota que seus contemporâneos insistem na consagração desse epíteto ["irmão do Padre Antônio Vieira"]. De fato, o apelido o acompanhou a vida inteira, seja nas referências literárias ou nos registros dos documentos, onde o parentesco com "o dito" [Padre Vieira] sempre lhe qualificava a pessoa, seja na vida prática, quando foram os feitos daquele que lhe garantiram o acesso ao estamento burocrático. (...) as mercês que lhe foram feitas (ou por vezes "desfeitas"), a despeito dos seus poucos méritos militares, foram-no sobretudo em consideração ao serviço do ilustre irmão. ${ }^{443}$

\footnotetext{
${ }^{438}$ O próprio Barbosa Machado atribui a Bernardo Ravasco um soneto, A hum papagayo de Palacio, que fallava muito, publicado no tomo III da Fênix Renascida (p.254) sem autoria definida.

439 “À morte de Bernardo Vieira Ravasco, Secretário do Estado do Brasil. Soneto XV. // Idéia ilustre do melhor desenho / Fostes entre o trabalho sucessivo, / E nas ordens do Estado sempre ativo / Era o zelo da Pátria o vosso empenho. // Ostentastes no ofício o desempenho / Com pronta execução, discurso vivo, / E formando da pena o vôo altivo, / Águia se viu de Apolo o vosso engenho. // Despede a morte, cegamente irada, / Contra vós ũa seta rigorosa, / Mas não vos tira a vida dilatada: // Que na fama imortal, e gloriosa, / Se morrestes como Águia sublimada, / Renasceis como Fênix generosa." (Oliveira, M. B. de. Poesia completa: Música do Parnasso, Lira Sacra, op.cit., pp.77-78).

${ }^{440}$ História da América portuguesa desde o ano de 1500 de seu descobrimento até ao de 1724. São Paulo/Belo Horizonte: Edusp/Itatiaia, 1976 [1730], p.56.

${ }^{441}$ Bibliotheca Lusitana. Tomo I, op.cit., p.538.

${ }^{442}$ Vale citar, como exemplo, o soneto de Botelho de Oliveira, Ponderação da morte do Padre Antônio Vieira, e seu irmão Bernardo Vieira ao mesmo tempo sucedidas: "Criou Deus na celeste Arquitetura / Dois luzeiros com giro cuidadoso, / Um que presida ao dia luminoso, / Outro que presidisse à noite escura. // Dois luzeiros também de igual ventura / Criou na terra o Artífice piedoso; / Um, que foi da Escritura Sol famoso, / Outro, Planeta da ignorância impura. // Brilhando juntos um e outro luzeiro, / Com sábia discrição, siso profundo, / Não podia um viver sem companheiro. // Sucedeu justamente neste Mundo, / Que fenecendo aquele por primeiro, / Este também feneça por segundo." (Poesia completa: Música do Parnasso, Lira Sacra, op.cit., p.78).

${ }^{443}$ Puntoni, P. "Bernardo Vieira Ravasco, secretário do Estado do Brasil: poder e elites na Bahia do século XVII". In: Novos Estudos. CEBRAP, São Paulo, v. 68, 2004, p. 108-109.
} 
São também assim referidas aquelas suas supostas décimas transcritas na Fênix Renascida: "De Bernardo Vieira Ravasco, irmão do Padre Antônio Vieira". Do mesmo modo, no citado manuscrito de Correia Vianna, as Saudades de Lídia e Armido teriam sido compostas “por Bernardo Vieira Ravasco, irmão do grande Pe. Antônio Vieira da extinta Companhia de Jesus". No entanto, nessas Saudades, ressalta-se a auctoritas do poeta Ravasco: uma rara imitação que, com estilo agudo e doutrina vária, faz do amor agudezas. O assunto desse poema é esclarecido pela "advertência" que antecede sua primeira oitava:

No tempo em q̃. com as successivas guerras com Castella, por sostentar Portugal a Coroa no seu Legitimo acclamado Rey os̃. D. João $4^{\circ}$, havia por cauza de irem á Campanha, a experimentada, e triste separaçaõ dos filhos de suas Maỹs, dos Espozos, de suas Espozas $\&^{\mathrm{a}}$, moveu a compaixão de algũns Engenhos poeticos desse tempo a pintarem essas lastimozas partidas, com o titulo de $=$ Saudades de Lydia, e Armido ,= como alem de outras, foram as q̃. compôs o $\mathrm{D}^{\mathrm{o}}$. Ant ${ }^{\circ}$. Barboza Bacelar, primeiras, e segundas; hũas $\tilde{\mathrm{q}}$. vem impressas no $1^{\circ}$ Tom. das Fenix a pag. 77; outras no $2^{\circ}$ Tom. pg.33; e em competencia dellas, as $\tilde{\mathrm{q}}$. compôs outro Engenho, e vem tambem impressas no Tom. $1^{\circ}$ da $\mathrm{d}^{\mathrm{a}}$. Fenix pg. 32. E assim, entre a occurrencia destes enthusiasmos, tocou parte ao Autor das presentes que declarado fica no rosto antecedente $\&^{\mathbf{a}}{ }^{444}$

Dessa maneira, tais Saudades ditas de Bernardo Ravasco, bem como as outras referidas, tratam da "experimentada e triste separação" entre entes queridos que, motivada pela Guerra de Restauração durante o reinado de D. João IV, moveu à compaixão alguns “engenhos poéticos", representando-se, principalmente nas personae de Armido e Lídia, a "lastimosa partida" do amante-amado, para combater na guerra, e as saudades ou sofrimentos da amada-amante. Contudo, persona também principal é o próprio amor: pinta-se e canta-se sua aguda concepção poética. Assim, na primeira oitava do poema, já se mostra agudo o estilo que, imitando o Camões épico e o Góngora lírico, cantará matéria trágico-amorosa:

Era o tempo gentil, em que as boninas

${ }^{444}$ Saudades de Lidia, e Armido, op.cit., pp.175-176. 
a respirar no berço comessavam,

renovando as memorias perigrinas,

que á vida de suas cores trasladavam:

Emulas fixas de outras mais divinas,

seu campo azul mentido equivocavam;

Lascivo engano ao Deos, que bruto, a Copa

deixou de Ganimedes por Europa. ${ }^{445}$

Nessa oitava, ecoa aquela do Canto II dos Lusíadas:

Era no tempo alegre quando entrava

No roubador de Europa a luz Febeia,

Quando um e o outro corno lhe aquentava,

E Flora derramava o de Amalteia.

A memória do dia renovava

O pressuroso Sol, que o Céu rodeia,

Em que Aquele a quem tudo está sujeito

O selo pôs a quanto tinha feito; ${ }^{446}$

Porém, a esses ecos de Camões se misturam aqueles dos primeiros versos das Soledades de Góngora, para então repercutirem todos juntos na mencionada primeira oitava das Saudades de Lídia e Armido:

Era del año la estación florida

en que el mentido robador de Europa

(media luna las armas de su frente,

y el Sol todos los rayos de su pelo),

luciente honor del cielo,

en campos de zafiro pace estrellas,

cuando el que ministrar podía la copa

a Júpiter mejor que el garzón de Ida,

náufrago y desdeñado, sobre ausente,

lagrimosas de amor dulces querellas

da al mar, que condolido,

${ }^{445}$ Idem, p. 177.

${ }^{446}$ Os Lusíadas, canto II, 75. In: Camões, L. de. Obras completas, op.cit., p.50. 
fue a las ondas, fue al viento

el mísero gemido,

segundo de Arión dulce instrumento. ${ }^{447}$

Assim, compreende-se melhor o "tempo gentil" em que se inicia o poema atribuído a Ravasco: trata-se do "tempo alegre" do verso camoniano ou da "estación florida" do gongórico, isto é, refere-se à primavera, ou melhor, ao princípio dessa estação florida, quando as boninas começam a surgir no campo, mudando-se suas cores. E são essas boninas, devido às suas vivas cores ou ao seu intenso brilho, "êmulas fixas" das estrelas, fazendo com que o campo seja um céu mentido. Zeus, caindo nesse lascivo engano, abandona Ganimedes, que cuidava da "copa" dos deuses no Olimpo, pois fora

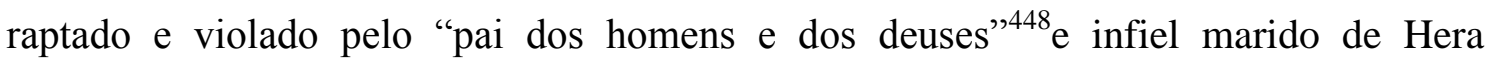
metamorfoseado em águia; abandona Ganimedes, descendo de sua divina morada, para tomar a forma de touro ("bruto") e também raptar e violar Europa. Portanto, essa referência mitológica, na esteira daquelas da mencionada oitava dos Lusíadas e dos versos das Soledades, confirma que o "tempo gentil" é a primavera, mais especificamente, abril, quando o sol entra na constelação de touro.

Além disso, tais modelos dessas Saudades de Lídia e Armido indicam uma possível discussão quanto ao gênero do poema. Este é composto por oitavas, com decassílabos heroicos, aproximando-se bastante da epopeia camoniana. Todavia, não se trata de assunto heroico (e sim lírico) e o seu agudo estilo, imitando constantemente aquele do Góngora da Fábula de Polifemo y Galatea e das Soledades, não se mostra adequado à poesia épica. Diante da indefinição da lírica no século XVII, discutida no primeiro capítulo deste trabalho, é pertinente retomar alguns aspectos da célebre polêmica acerca da poesia gongórica, para situar tais Saudades, ditas de Bernardo Ravasco, em meio à indeterminada e, por isso, ampla e variada lírica amorosa seiscentista.

Como se sabe, no início do século XVII, é grande a controvérsia em torno da Fábula de Polifemo y Galatea e das Soledades, havendo tanto detratores quanto defensores da poesia (em especial, da linguagem poética) de Góngora. Não é objetivo deste estudo expor, detalhadamente, essa controvérsia, que já foi devidamente analisada

\footnotetext{
${ }^{447}$ Góngora, L. de. Soledades. Edición de John Beverley. Madrid: Cátedra, 2007, pp.75-76.

${ }^{448}$ É esse um dos epítetos de Zeus na Teogonia de Hesíodo (v.542).
} 
em outros trabalhos, ${ }^{449}$ mas destacar uma questão fundamental para a compreensão daquele poema manuscrito na Miscelânea de Correia Vianna: os instáveis limites, nos anos Seiscentos, entre os gêneros poéticos, particularmente, entre a épica e a lírica. Nesse sentido, são muito úteis as críticas de Juan de Jáuregui no seu Antídoto contra la pestilente poesía de las Soledades, considerado um texto capital na polêmica gongórica, conforme José Manuel Rico García:

Ciertamente, el Antídoto trazó las líneas maestras por las que habría de discurrir la controversia en torno a la nueva poesía, circunstancia que convierte a esta obra en un documento insustituible para poder medir la influencia que las Soledades ejercieron en la teoría del lenguaje poético del Siglo de Oro. (...) La divulgación del Antídoto contra la pestilente poesía de las Soledades desató la afluencia de ensayos, pareceres, comentarios, exámenes y escritos de toda índole en los que se expresaron las opiniones más pertinentes sobre los problemas de la lengua poética barroca. Este argumento ha servido para que el Antídoto sea una referencia obligada en el estudio de la controversia sobre la poesía de Góngora y de la teoría y práctica poéticas de la literatura del siglo XVII. ${ }^{450}$

Desse modo, no começo de seu Antídoto, Jáugueri expõe o propósito de seu escrito: "Aunque muchos hombres cuerdos y doctos desean con buena intención desengañar a V.m. y aconsejarle no escriba versos heroicos, no lo llegan a intentar." ${ }^{451}$ Fará, então, Jáugueri aquilo que outros não ousaram fazer: “me atrevo a persuadirle, por evidentes causas, que no nació para poeta concertado, ni lo sabe ser, ni escribir versos en juicio y veras, por mengua de natural y por falta de estudio y arte. ${ }^{\text {452 }} \mathrm{Na}$ opinião do crítico, portanto, o que tenta escrever Góngora nas Soledades são "versos heroicos" e toda sua crítica se fundará no fato de que seria o poeta cordovês inapto para escrever no

\footnotetext{
${ }^{449}$ Entre os diversos estudos dedicados ao tema, podem-se citar, apenas como exemplos, os seguintes: Orozco Díaz, E. En torno a las "Soledades" de Góngora. Ensayos, estudios y edición de textos críticos de la época referentes al poema. Granada: Universidad de Granada, 1969; Orozco Díaz, E. Lope y Góngora frente a frente. Madrid: Gredos, 1973; Martínez Arancon, A. La batalla en torno a Góngora. Barcelona: Antoni Bosch, 1978; Pariente, A. En torno a Góngora. Madrid: Júcar, 1986; Roses Lozano, J. Una poética de la oscuridad. La recepción crítica de las "Soledades" en el siglo XVII. Madrid: Támesis, 1994.

${ }^{450}$ Jáuregui, J. de. Antídoto contra la pestilente poesía de las Soledades. Estudio y edición crítica de José Manuel Rico García. Sevilla: Secretariado de Publicaciones de la Universidad de Sevilla, 2002, pp.X-XI.

${ }_{451}$ Idem, p.3.

${ }^{452}$ Idem, p.4.
} 
gênero épico, ou seja, não teria nascido ele para ser um "poeta concertado". Assim, o "estilo novo" de Góngora, com sua dificuldade excessiva, não seria louvável por não ser agradável e aprazível ao gosto de muitos ou, pelo menos, dos melhores, e sim digno de censura por ser tão contrário ao gosto de todos. Essa exagerada "novidade" torna o estilo gongórico inapropriado para versos grandíloquos e heroicos que seriam, segundo Jáugueri, aqueles que busca escrever o poeta em suas Soledades:

Hase de advertir que la novedad en tanto es loable en cuanto es grata y apacible al gusto de muchos o a los mejores. Este nuevo estilo de V.m. es tan contrario al gusto de todos que ningún esforzado ánimo ha podido leer cuatro columnas destos solitarios versos sin estrujada angustia de corazón, como lo vemos experimentar a mil personas discretas y capaces de la buena poesía. Su intento de V.m. aquí fue de escribir versos de altísimo lenguaje, grandílocos y heroicos. El que mejor hizo esto fue Virgilio Marón; pues cotejado su estilo con el de V.m. es tan diferente y opuesto que cualquier español con dos maravedís de gramática entenderá fácilmente los versos del poeta, y los de V.m., con ser en su lengua vulgar, no los entenderá ni aun con dificultad. $^{453}$

Reprovando, por fim, não só as Soledades, mas também La Fábula de Polifemo y Galatea, conclui Jáugueri: “Hora, señor, V.m. fue mal aconsejado el día que se metió a poeta cuerdo (...). Antes nos parecía imposible, al cabo de cincuenta años que V.m ha gastado entre las musas líricas y joviales, que se le hubiese pegado tan poquito de las heroicas". ${ }^{454}$ Tendo sempre sido um poeta das musas líricas e joviais, Góngora não deveria ter tentado sê-lo das heroicas, visto que não soube ponderar as dificuldades de composição do poema heroico:

Debiera V.m., según esto, ponderar las muchas dificultades de lo heroico, la constancia que se requiere en continuar un estilo igual y magnífico, templando la gravedad y alteza con la dulzura y suavidad inteligible, y apoyando la elocución al firme tronco de la buena fábula o cuento, que es el alma de la poesía. Para los juguetes no es necesario

\footnotetext{
${ }^{453}$ Idem, pp.18-19.

${ }^{454}$ Idem, p.79.
} 
tanto aparato ni esta sosegada prudencia, sino un natural burlesco y estar de gorja. Por tanto, V.m. se ha destruido después que emprende hazañas mayores que sus fuerzas, y aun de lo burlesco da muy mala cuenta de algunos años a esta parte. $\mathrm{Y}$ no se fíe en que se leen y procuran sus versos juguetones o satíricos, que eso no va en su bondad, sino en la matéria pícara y disoluta que contienen, a cuya malicia se inclina fácilmente la flaqueza humana. ${ }^{455}$

Nota-se, dessa maneira, que uma das principais censuras do Antídoto é a inadequação do "novo estilo" gongórico ao gênero heroico, no qual se inseririam as Soledades. Todavia, dois daqueles citados versos iniciais do poema de Góngora suscitam questionamentos quanto à sua inserção em tal gênero: "lagrimosas de amor dulces querellas" e "segundo de Arión dulce instrumento". Isso porque, as doces e lacrimosas querelas são de amor e, mais ainda, são líricas, pois Árion foi um poeta lírico que se fez rico e famoso e que, voltando um dia a Lesbos, sua terra natal, foi lançado do barco ao mar pelos tripulantes que queriam apoderar-se de seu tesouro; por isso, o mísero gemido do peregrino é como a lira de Árion: um dulce instrumento que solicita a ajuda de Vênus. O canto desse doce instrumento é, enfim, lírico amoroso, embora com um elevado estilo que soa heroico. Enfim, como assinala Jesús Ponce Cárdenas:

La prodigiosa hibridación que Góngora va entretejiendo sobre el cañamazo narrativo de su obra permite, en definitiva, afirmar que el racionero «peregrina por los géneros y estilos conocidos a fin de plasmar uno nuevo que, por un lado, toma de los demás lo precedente y, por otro, los sortea para no caer de lleno en ninguno». Las Soledades constituyen así un novedoso epos dotado de valores líricos, que va tanteando formas y contenidos tan dispares como los ofrecidos por la tradición epidíctica de la dedicatoria y el epodo execratorio contra las navegaciones, la égloga pastoril y el epitalamio, la poesía venatoria y la haliéutica. $^{456}$

Esse difícil e novo estilo gongórico ressoa também agudo na segunda estância daquelas Saudades de Lídia e Armido:

\footnotetext{
${ }^{455}$ Idem, pp.80-81.

${ }^{456}$ Cárdenas, J. P. Góngora y la poesía culta del siglo XVII. Madrid: Laberinto, 2001, p.85.
} 
Quando nas ondas, que ilustrou, surgindo

aquelle fatal Grego, aquem recreya,

seus marmores lavando, e consumindo

em cinzas Troya, em muros Ulyssea:

Dos Lenhos, que o valor foi construindo,

para serem do Sol nadante estrêa,

galhardos, e guerreiros authorisam

o Ceo que ofendem, e o cristal que pisam. ${ }^{457}$

A sintaxe e as metáforas desses versos os tornam de tão difícil compreensão que, a respeito deles, se poderia dizer aquilo que, como já mencionado, disse Jáugueri sobre a poesia gongórica do Polifemo e das Soledades, comparando-a com a de Virgílio: "pues cotejado su estilo con el de V.m. es tan diferente y opuesto que cualquier español con dos maravedís de gramática entenderá fácilmente los versos del poeta, y los de V.m., con ser en su lengua vulgar, no los entenderá ni aun con dificultad." Tal dificuldade, que faz quase ininteligíveis, a qualquer português, os citados versos das Saudades (supostamente) de Bernardo Ravasco, ainda se intensifica com uma comparação por oposição: "aquelle fatal Grego" parece ser Ulisses que, finda a guerra de Troia, deixou a cidade consumindo em cinzas para, numa longa e árdua viagem marítima, retornar à sua Ítaca e reencontrar seu filho e sua esposa. Mas, na segunda parte dessa oitava, em que se desenvolve a comparação, os "lenhos que o valor foi construindo" têm uma função justamente oposta: levar para longe (e talvez para nunca mais voltarem) de suas esposas, de suas mães, de seus filhos, aqueles que vão para a guerra, lutar contra Castela "por sostentar Portugal a Coroa no seu Legitimo acclamado Rey D. João 4\%". Essas naus são do sol "nadante estreia" porque partirão assim que amanhecer, dando autoridade ao céu que ofendem por serem novo galhardo sol e à água que pisam como altivos guerreiros.

Diante da dificuldade dessa oitava portuguesa, é pertinente recordar a Carta de un amigo de don Luis de Góngora que le escribió acerca de sus Soledades, um dos primeiros documentos conhecidos da polêmica sobre as Soledades e que, de acordo com Emilio Orozco Díaz, teria sido escrita por Lope de Vega e/ou por um grupo de amigos seus. Nessa carta se considera, ironicamente, não ter sido esse controverso poema

${ }^{457}$ Saudades de Lidia, e Armido, op.cit., p.178. 
gongórico escrito em castelhano, nem em latim e nem em grego, mas numa confusão de línguas como aquela de Babel:

pues es cierto que si las [Soledades] quisiera escribir en nuestra lengua vulgar, igualan pocos a V.m.; si en la latina, se aventaja a muchos; y si en la griega, no se trabaja tanto para entenderla que en lo que V.m. ha estudiado no pudiera escribir seguro de censura y cierto de aplauso. Y como ni en éstas ni en las demás lenguas del Calepino están escritos los tales soliloquios, y se cree que V.m. no ha participado de la gracia de Pentecostés, muchos se han persuadido que le alcanzó algún ramalazo de la desdicha de Babel... ${ }^{458}$

Por isso, uma língua poética assim tão confusa e incompreensível, talvez por que tenha querido Góngora, "por mostrar su agudeza, defender que merece alabanza por inventor de dificultar la construcción de el romance", não alcança os fins que deve ter toda invenção, "pues las invenciones en tanto son buenas en cuanto tienen de útil, honroso y deleitable". ${ }^{459}$ A essa última crítica, baseada no prodessere et delecatre horaciano, que já foi discutido no primeiro capítulo deste trabalho, rebate Góngora em sua Carta en respuesta de la que le escribieron, com argumentos fundamentais (que também recorrem às fontes antigas) para se compreender a defesa da novidade, dificuldade e obscuridade na aguda poesia do século XVII, sem que, para isso, sejam desrespeitados os preceitos e os modelos retórico-poéticos antigos. Argumenta então o poeta cordovês, seguindo a ordem daquela censura, por que seriam, em primeiro lugar, suas Soledades úteis:

Pregunto yo: ¿han sido útiles al mundo las poesías y aun las profecías (que vates se llama el profeta como el poeta)? Sería error negarlo; pues, dejando mil ejemplares aparte, la primera utilidad es en ellas la educación de cualesquiera estudiantes de estos tiempos; y si la obscuridad y estilo entrincado de Ovidio (...) da causa a que, vacilando el entendimiento en fuerza de discurso, trabajándole (pues crece con cualquier acto de valor), alcance lo que así en la lectura superficial de sus versos no pudo entender, luego hase de confesar que tiene utilidad

\footnotetext{
${ }^{458}$ Góngora, L. de. Soledades, op.cit., p.169.

${ }^{459}$ Idem, p. 170 .
} 
avivar el ingenio, y eso nació de la obscuridad del poeta. Eso mismo hallará V.m. en mis Soledades, si tiene capacidad para quitar la corteza y descubrir lo misterioso que encubren. ${ }^{460}$

É útil, portanto, o estilo gongórico do Polifemo e das Soledades, pois, sendo obscuro, do mesmo modo que o foi Ovídio, faz com que se trabalhe o entendimento para alcançar aquilo que com uma leitura superficial não se pode entender, avivando, assim, o engenho. Se essa "educação" é sua utilidade, esclarece-se, em seguida, o que tem de honroso:

De honroso, en dos maneras considero me ha sido honrosa esta poesía: si entendida para los doctos, causarme ha autoridad, siendo lance forzoso venerar que nuestra lengua a costa de mi trabajo haya llegado a la perfección y alteza de la latina, a quien no he quitado los artículos, como le parece a V.m. y esos señores, sino excusándolos donde no necesarios; y así gustaré me dijese en dónde faltan, o qué razón de ella no está corriente en leguaje heroico (que ha de ser diferente de la prosa y digno de personas capaces de entenderle), que holgaré construírsela, aunque niego no poder ligar el romance a esas declinaciones, y no doy aquí razón cómo: porque es para convencer, la pregunta que en esto V.m. me hiciere. Demás que honra me ha causado hacerme escuro a los ignorantes, que esa es la distinción de los hombres doctos, hablar de manera que a ellos les parezca griego; pues no se han de dar las piedras preciosas a animales de cerda. ${ }^{461}$

A honra dessa poesia é ser compreendida apenas pelos doutos e, sendo admirada por eles, que lhe dão autoridade, torna-se forçoso admitir e respeitar a capacidade desse trabalho poético de fazer do castelhano uma língua que se iguale em perfeição e em alteza à latina. Para tanto, e esse é o segundo aspecto honroso da poesia gongórica, é necessário que se faça obscura aos ignorantes, para se assinalar a intransponível distância que há entre esse elevado trabalho da razão e a ignorância daqueles que não o entendem, como se fossem dadas pedras preciosas a porcos. Dessa maneira, estando

\footnotetext{
${ }^{460}$ Idem, pp.171-172.

${ }^{461}$ Idem, p. 172.
} 
devidamente justificadas a utilidade e a honra das Soledades, resta esclarecer seu deleite, que decorre daquilo que já foi afirmado sobre aquelas duas outras finalidades:

Deleitable tiene lo que en los dos puntos de arriba queda explicado, pues si deleitar el entendimiento es darle razones que le concluyan y se midan con su contento, descubriendo lo que está debajo de esos tropos, por fuerza el entendimiento ha de quedar convencido, y convencido, satisfecho; demás que, como el fin de el entendimiento es hacer presa en verdades, que por eso no le satisfache nada, si no es la primera verdad, conforme aquella sentencia de san Agustín: Inquietum est cor nostrum, donec requiescat in te, en tanto quedará más deleitado, cuanto, obligándole a la especulación por la obscuridad de la obra, fuera hallando debajo de las sombras de la obscuridad asimilaciones a su concepto. $^{462}$

Como se vê, justifica-se a obscuridade poética com base nos mesmos princípios com que a recriminam: ela ensina, avivando o engenho, e deleita, na medida em que o entendimento vai descobrindo verdades debaixo das aparentes sombras. Essa obscuridade, útil e deleitável, é fundamental naquela poética da agudeza, que foi abordada, mais detidamente, no primeiro capítulo deste estudo. Se já está demonstrado - no referido, diversas vezes, trabalho de Maria do Socorro Fernandes de Carvalho, Poesia de agudeza em Portugal - que na produção poética portuguesa do século XVII a agudeza é noção central, entre os preceptistas portugueses seiscentistas também se criticam os excessos dessa aguda concepção poética, especialmente, a incompreensível obscuridade que ela pode gerar. Manuel Pires de Almeida, por exemplo, em seu Discurso sobre o Poema Heroico, logo após tratar dos "conceitos agudos", faz uma advertência contra aqueles poetas modernos, chamados "cultos" por ironia, que afetam excessivamente a obscuridade e só usam o "estilo dificultoso":

De aqui nasce outra dúvida digna de muita advertência principalmente para o poetar de nosso tempo: há alguns poetas que afetam tanto a obscuridade que querem qualificá-la por verdadeira poesia, e só usam do estilo dificultoso, orações desatadas, palavras esquisitas, translações nunca vistas, locuções peregrinas, tropos duplicados, figuras e

\footnotetext{
${ }^{462}$ Idem, pp.172-173.
} 
metáforas mui continuadas, e sobretudo a colocação das coisas e disposição do argumento intricado, sem ordem, nem arte, nem claridade: confesso que não achei até agora autor sábio em esta arte que aprovasse doutrina tão falsa e mal-fundada; antes muitos que condenam dos antigos e dos modernos, infinitos sisudos e mui doutos que se queixam e maldizem os primeiros inventores desta seita a que vulgarmente chamam Cultos, por ironia, e sendo assim que este modo de poetar dificultoso é o mais fácil de todos, porque só se anda à caça de palavras e figuras sem outras disposições e advertência; contudo me persuado a que foi piedade do Céu para que acabasse de morrer a poesia, que há tanto tempo que anda expirando por mãos de ignorantes, por despenhá-la desta companhia tão aborrecida de seu deleite, sua venustidade, brandura, suavidade, sua clareza, limpa, pura, tersa, seu espírito levantado, proporcionado à matéria, nem túmido, nem humilde, porém galhardo, estilo fácil, brando, deleitável, espirituoso etc. ${ }^{463}$

Encerra, então, Pires de Almeida seu tratado explicando que há quatro diferentes obscuridades. A primeira, boa, é a artificiosa, ou seja, aquela "que nasce, ou da alteza do conceito, ou da indústria do poeta, por algum particular que repreende". A segunda, que é louvada e excelente, "se origina da muita lição". A terceira, única viciosa e condenada, é aquela "que se produz da falta de invenção, de confusão de engenho, de ruim colocação de conceitos intricados e dificultosos, da disposição das palavras, dos tropos, das figuras, da eleição das coisas et sic de coeteris". Finalmente, a quarta é a alegórica, muito comum na poesia épica e nos livros sagrados, sendo, por isso, de grande louvor, excelência e primor, "por donde consegue o primeiro lugar". 464

Outro preceptista português dos anos Seiscentos, o já tantas vezes mencionado Manuel de Faria e Sousa, censura igualmente os modernos poetas chamados "cultos". Nas Advertencias contra la opinion moderna acerca de lo que es Poesia da primeira parte de sua Fuente de Aganipe, Faria e Sousa elege como melhores poetas líricos "de España" Ausiàs March, Garcilaso e Camões, mencionando ainda, obviamente não "de España”, Petrarca. Depois desses, muitos, tanto castelhanos quanto portugueses, escreveram "en el lenguaje que oy se llama brillante, i nadie los lee, ni conece. Siguese que vozes espejadas no hazen Poeta; i que no deshazen Poeta las escabrosas, rusticas, i

\footnotetext{
${ }^{463}$ Pires de Almeida, M. Discurso sobre o Poema Heroico, op.cit., p.11.

${ }^{464}$ Idem, pp.11-12.
} 
vulgares". ${ }^{465}$ Isso porque, "de ningun modo consiste la Poesia en buenos dichos, ni aun en altos concetos, o solidas sentencias, ni en versos muy peynados". ${ }^{466}$ Contudo, demonstra um total desconhecimento do que seja poesia quem "escuridad culpable a lo que se dize tocando reconditas erudiciones: porque en esto, $\mathrm{i}$ en elevacion de pensar, $\mathrm{i}$ en alegoria, ha de ser dificil de entender el Poeta: mas en ninguna manera lo ha de ser en el lenguage". ${ }^{467}$ Por isso, conclui-se que se pode e se deve fugir, justamente, daquele escritor que só é difícil de entender devido ao seu estilo, por usar, excessivamente, vozes peregrinas, tropos, transposições, metáforas duras, hipérboles insolentes, períodos prolixos, "de modo que ha de ser necessario declarar en Castellano lo que quiere dezir una clausula Castellana en que no ay erudicion alguna: i esto se llama Poesia". ${ }^{468}$ Em outras palavras, como afirma o mesmo Faria e Sousa no "Prólogo" às Rimas Várias de Camões, não é poeta, e sim mero versificador, aquele que

escrive con palabras tan estrañas, y con clausulas tan intrincadas, que sea necessario explicarse con la misma lengua en que él escrive, lo que quiere dezir la clausula en lo que toco á la contextura de ella: porque en esto deben ser las clausulas tan claras, que las entienda el ignorante: lo que es licito escrivir de modo que dé cuydado al docto para entenderle tal vez, es en la elevacion de los pensamientos, en la erudicion recondita, en lo mysterioso de la alegoria, en la armonia que hazen entre si varios lugares, siendo unos la declaracion de los otros. ${ }^{469}$

Nos seus comentários aos Lusíadas, combatendo ainda mais explicitamente os poetas "cultos" de seu tempo, o comentador, ao discorrer acerca do "Reino de Congo" mencionado no canto $\mathrm{V}$ da epopeia camoniana, declara, ironicamente, que o vocábulo "coltos" ou "cultos" derivar-se-ia, por corrupção, de "congos" ou "cungos", pois tanto aqueles modernos poetas “de España" como "estes negros, a que llamamos bestias", naturais do Congo, prezam-se por falar tão agudamente, "haziendose muy superiores de entendimiento, $\mathrm{i}$ aun de elegancia, porque quanto al estilo casi perpetuamente hablan

\footnotetext{
465“Advertencias contra la opinion moderna acerca de lo que es Poesia”, §3. Fuente de Aganipe o Rimas Varias. Parte Primera, op.cit.

${ }^{466}$ Idem, $\S 4$.

${ }^{467}$ Idem, $§ 13$.

${ }^{468}$ Idem, §14.

469 "Prólogo", §6. Rimas Varias de Luis de Camoens... Comentadas por Manuel de Faria y Sousa. Primeira Parte, op.cit.
} 
por metaforas, i circunloquios exquisitos". ${ }^{470}$ No entanto, no "Juicio del Poema" que antecede esses seus comentários aos Lusíadas, Faria e Sousa, embora afirmando que Góngora poderia ter tido maior fama "si no quisiera irse tanto tras la escabrosidad, a titulo de nuevas osadias", não condena de todo (sem deixar de lado a ironia) a difícil poesia gongórica do Polifemo e das Soledades e a de seus imitadores, comparando-as com uma dura pinha, enquanto a poesia de Homero, a de Virgílio e a de seus seguidores se parecem com doces pêssegos:

No piense alguno, por ventura, que don Luis de Gongora, i los que él imitó, i le imitaron, dixeron cosa que de algun modo no sea entendida de quien tiene entendimiento, i noticia destos estudios, i locuciones. Piense solamente, que son entendidos con trabajo, molestia, i rabia: i que reduzir a esta estrecheza los juizios, es menor hazaña que la de saborearlos con la fazon de Virgilio, i de su escuela: con q̃ quedan siendo los manjares soberanos del ingenio, i essotros las frutas quando mucho, para entretenermos: como la piña, que sobre obligaros con aquella tenaz, aunque vistosa compostura de corteza, a poner gran trabajo en abrirla, a la postre os dá el nonada de un piñon, i esse aun armado de otra dificultad: siendo assi, que Homero, i Virgilio, i toda su classe, en contrario, se parecen a hermosos, i dulces melocotones, i datiles con la belleza, i suavidad, i dulçura de los terminos del dezir, que luego empeçamos a gustar; i despues topamos en el coraçon un poco dificil, ya de la alegoria, ya de la sentencia, ya de la alusion, ya del misterio, i otros intentos, que se hazen más ayrosos al penetrarse con la precedencia de aquella suavidad, i dulçura con que primero nos obligaron. $^{471}$

Os referidos comentários, tanto aqueles de Pires de Almeida quanto estes de Faria e Sousa, indicam que, também em Portugal no século XVII, é grande o debate em torno da dita poesia "culta", em particular daquela que decorre do difícil e obscuro modelo gongórico. A importância desse modelo para a produção poética portuguesa dos anos Seiscentos evidencia-se, por exemplo, nas diversas imitações e contrafações dos poemas gongóricos presentes na Fênix Renascida ou, ainda, devido ao fato, apontado

\footnotetext{
${ }^{470}$ Lusíadas de Luís de Camões - Comentadas por Manuel de Faria e Sousa. Volume I. Lisboa: IN CM, 1972, Canto V, col.471.

${ }^{471}$ Idem, "Juizio del Poema", col.66-67.
} 
por Maria de Lurdes Belchior Pontes, de ser Góngora, ao lado de Camões, os poetas mais citados, autorizados e encomiados na Nova arte de conceitos de Francisco Leitão Ferreira que, embora censure, vez ou outra, o poeta cordovês, qualifica esse "célebre hespanhol que, por escuro se fez esclarecido" como "excelente", "celebrado", "engenhoso", “famoso", “culto", “ilustre" etc. ${ }^{472}$ Como essa autoridade da poesia gongórica já se encontra, em termos gerais, devidamente ressaltada e estudada no trabalho de José Ares Montes, Góngora y la poesia portuguesa del siglo XVII, recorrese a ela, nesta tese, com um objetivo específico: buscar uma melhor compreensão daquelas Saudades de Lídia e Armido atribuídas a Bernardo Ravasco. Mais especificamente ainda, essas Saudades mostram que o agudo amor da variada lírica seiscentista é também gongórico.

Assim, quando naquelas lenhos, "que o valor foi construindo," embarcam os que vão para guerra, tendo que deixar em terra seus entes queridos, menciona-se no poema, pela primeira vez, o amor:

Deu, de hũ bronze ferido o ingrato alento,

o primeiro signal á forte Armada:

Altera o Mar o féro movimento;

perturba a Terra a Leva inopinada:

Tudo abala o confuso sentimento;

a nada acerta a pressa alvorossada:

Ferve o embarcar nas Naos em toda a parte;

em toda geme Amor, padece Marte.

Padece Marte; porque o mais briozo

se sente ao despedir menos valente;

que o termo de apartarse, he taõ penozo,

que o sente fraco quem feroz naõ sente:

Geme Amor; porq̃. o impede maviozo

dos coraçoẽns a fama impaciente;

transformando esta doce tirania

o Amor em morte, a morte em tirania. ${ }^{473}$

\footnotetext{
${ }^{472}$ Cf. Pontes, M. de L. B. "Góngora e os cultos, segundo a retórica conceptista, de Francisco Leitão Ferreira - Nova Arte de Conceitos". In: Separata do Vol. III das Actas do V Colóquio Internacional de Estudos Luso-Brasileiros, Coimbra, 1966, p.13.

${ }^{473}$ Saudades de Lidia, e Armido, op.cit., p.179.
} 
O amor surge, então, gemendo, porque embarcam nas naus aqueles que, para lutar em busca da "fama impaciente", abafam em seus corações as amorosas saudades. Contudo, mesmo Marte guerreiro padece, pois o mais corajoso se sente, na despedida, menos valente; e o apartar-se é tão penoso que senti-lo pouco é não ter sentimentos. Essa doce, porque amorosa, tirania faz do amor, no partir-se, morte e a morte, nas saudades, amorosa tirania. Confundem-se, dessa forma, o amor, a morte e a tirania e são essas as agudas saudades que padecerão Lídia e Armido: o amor que é tirana morte.

Tal ausência amorosa é topos largamente glosado na lírica seiscentista: a vida longe de quem se ama é morte viva ou vida morta, já que se sofre constantemente a ausência amada numa vida que é só penar ou que, partida, está morta na parte que falta. Nesse sentido, é válido transcrever um soneto de Violante do Céu que trata dessa vida, ao gosto morta, "que entre ausências permanece":

Vida que não acaba de acabar-se chegando já de vós a despedir-se, ou deixa por sentida se sentir-se, ou pode de imortal acreditar-se.

Vida que já não chega a terminar-se pois chega já de vós a dividir-se, ou procura vivendo consumir-se, ou pretende matando eternizar-se.

O certo é, senhor, que não fenece, antes no que padece se reporta, porque não se limite o que padece.

Mas, viver entre lágrimas, que importa? se vida que entre ausências permanece é só viva ao pesar, ao gosto morta. ${ }^{474}$

Uma vida assim entre amantes ausentes é uma vida de saudades. Tópico frequente da poesia portuguesa, a saudade já foi discutida por diversos estudiosos, desde, pelo menos, Carolina Michaëlis de Vasconcelos. ${ }^{475}$ Mas, no século XVII, uma

\footnotetext{
${ }^{474}$ Violante do Céu. Rimas Várias, op.cit., p.74.

${ }^{475}$ Vasconcelos, C. M. de. A saudade portuguesa: divagações filológicas e literar-históricas em volta de Inês de Castro e do cantar velho "Saudade minha - quando te veria?". Porto: Renascença Portuguesa, 1914.
} 
definição que muito contribui para a discussão das Saudades de Lídia e Armido é aquela que apresenta Faria e Sousa nos seus comentários aos Lusíadas, mais especificamente, quando discorre sobre o verso "Nos saudosos campos do Mondego" da estrofe 120 do canto III da epopeia camoniana:

...saudosos es derivacion de saudade: i aunque a algunos parece que en Castellano falta voz equivalente a esta, no ay duda, que lo es Soledad: Advirtiendose, que saudade en Portugues, no es otra cosa que Soidade, derivado de Soidam, que derechamente es soledad: i el dezir saudade es corrupcion: pero vino a ser corrupcion, como la del vino, quando se buelve finissimo vinagre; que siendo tal es más saludable, i un apetito regalado, i oloroso: assi la corrupcion de Soidade en Saudade, para el oydo Portugues, vino a parar en voz regalada, i más significativa, que la verdadera, del desseo, pena, i dolor ternissimo del bien ausente: i significacion que no se ajusta en otra lengua. ${ }^{476}$

Destaca-se, nesse comentário de Faria e Sousa, a equivalência entre a "saudade" portuguesa e a "soledad" castelhana, ainda que não sejam exatamente iguais suas significações, pois somente em português há esse vocábulo "saudade" para designar o desejo, a pena e a dor terníssima do bem ausente. Dessa maneira, é possível relacionar diversas saudades que se encontram na poesia seiscentista portuguesa com as soledades castelhanas, em particular com aquelas (polêmicas) gongóricas. Esse trabalho comparativo já foi feito pelo mencionado José Ares Montes ${ }^{477}$ que afirma, inclusive, que teria sido Antônio Barbosa Bacelar o primeiro cultivador de soledades em Portugal. Desse modo, conforme Montes, na célebre carta do conde de Portalegre sobre os "mistérios da saudade", frequentemente citada por aqueles estudiosos que se voltam para esse tema,

después de afirmarse la identidad afectiva de ambos conceptos, se enriquece al castellano con el significado de «estar solo», es decir, un contenido subjetivo-objetivo frente al exclusivamente subjetivo del portugués. Pero contra esta idea de la limitación portuguesa a un sentido afectivo (...) se oponen las imitaciones de las Soledades gongorinas, en

\footnotetext{
${ }^{476}$ Lusíadas de Luís de Camões - Comentadas por Manuel de Faria e Sousa, op.cit., Canto III, col.178.

${ }^{477}$ Montes, J. A. Góngora y la poesía portuguesa del siglo XVII, op.cit., pp.386-448.
} 
las que saudade tiene en primer lugar el significado de 'nostalgia' y en segundo el de 'estar solo', 'sin compañía': lo mismo que en el poema de Góngora. $^{478}$

Posto que com o emprego de termos que não condizem com a produção retórico-poética seiscentista, como "identidad afectiva", "contenido subjetivo-objetivo" e "sentido afectivo", esse trecho de Montes indica dois aspectos que, na verdade, se fundem e que estão presentes tanto nas Soledades gongóricas quanto nas Saudades da poesia portuguesa: a intensa dor ou tristeza (dita "nostalgia" pelo autor) de estar-se sozinho, sem companhia. Nesse sentido, o mesmo estudioso salienta que o náufrago peregrino das Soledades é um desenganado "que siente nostalgia de un bien perdido. En los campos, en las riberas, en las selvas o en el yermo se encuentra solo, saudoso - aun rodeado de serranas y pastores -, porque le falta la compañía por quien siente soledad, saudade". 479

$\mathrm{Na}$ lírica portuguesa seiscentista, um dos poetas a quem mais são atribuídas Saudades é Antônio Barbosa Bacelar, aquele que, na mencionada opinião de José Ares Montes, teria sido o primeiro a compor Soledades em Portugal no século XVII. Além daquelas duas Saudades de Lídia e Armido da Fênix Renascida, Bacelar teria composto, entre outras, umas Saudades de Aônio, também em oitavas com versos decassílabos. Nessas últimas, são cantadas as saudades de Aônio, que lamenta a morte, lembrando-se com penar, de sua amada Nise. Na terceira copla desse poema define-se, então, a saudade como "inimiga da luz" e ausência de toda companhia:

É inimiga da luz a saudade,

Oposta sempre a toda a companhia,

Que o mal, que tem de morte a qualidade,

De tudo o que é remédio se desvia;

Por isso, entregue a tanta enfermidade,

Aónio ao fenecer do claro dia,

Para todo empregar-se nos suspiros,

Busca no vale as sombras e os retiros. ${ }^{480}$

\footnotetext{
${ }^{478}$ Idem, p.388.

${ }^{479}$ Idem, p.389.

${ }^{480}$ Obras poéticas de António Barbosa Bacelar, op.cit., pp.182.
} 
Diante dessa saudade, que faz Aônio se isolar e se lamentar como saudoso amante, resta-lhe como única companhia a natureza, a quem dirige seus lamentos, e esse triste diálogo só aumenta seu sofrimento: seu pranto rega o vale e seus ais engrossam o vento. ${ }^{481}$ Gemer ou lamentar-se assim saudoso é mostrar que as dores são de soledade, pois esta "inimiga" converte o possível alívio em crueldade. Identificam-se, portanto, a saudade e a soledade, afastando o saudoso de qualquer convívio para intensificar seu "tirano tormento":

Porém como saudoso se lamenta,

Pois são de soledade as suas dores,

Por isso a pesar seu tanto se aumenta

O tirano tormento em seus rigores;

São repetidos ais em que arrebenta

Para ele, solitário, disfavores,

Porque faz inimiga soledade

Converter-se o alívio em crueldade. ${ }^{482}$

A saudade é também morte. Isso porque, como já destacado no capítulo anterior deste trabalho, numa perspectiva platônico-cristã, amar é viver o amante na amada e a amada no amante. Assim, Nise "não vivia em si somente" e, morrendo ela, morre igualmente o saudoso Aônio. Entretanto, morta Nise, apenas nas saudades, ou melhor, nas soledades sabe viver o amor, se forem firmes suas qualidades. Por isso, essas saudades de Aônio são, enfim, de duas mortes amadas uma solitária vida amante.

As veemências daquele amor ardente,

Que em ũa e outra alma se acendia,

Certo é que não vivia em si somente,

Em Aónio também Nise vivia;

Buscou-te pois, ó Nise, juntamente

Em mim da morte iníqua a fouce impia,

Para de todo assim desanimar-te

Combatendo a tua alma em toda a parte.

\footnotetext{
481 "Geme sentido Aónio e tanto emprega / Em seu coração triste o sentimento, / Que não só com seu pranto o vale rega / Mas também com seus ais engrossa o vento, / Fazendo com os alentos que desprega / De seu peito mais duro sentimento, / Que é pena a mais cruel achar os meios / Nos próprios males para os bens alheios." (Idem, p.183).

${ }^{482}$ Idem, p. 184.
} 
Porém se te alcançou em mim a morte

Em quanto aos sentimentos de perder-te,

Não é possível que seu golpe forte

Me alcance quanto às forças de querer-te;

Hei de correr de amante a mesma sorte

Posto que entre os pesares de não ver-te,

Que quando tem de firme as qualidades

Sabe viver o amor nas soledades. ${ }^{483}$

Esse agudo primeiro verso da última oitava mencionada, "porém se te alcançou em mim a morte", sintetiza a saudade como morte amada e vida amante, alterando o esperado sentido da frase com os surpreendentes usos dos pronomes "te" e "mim", afastados e, ao mesmo tempo, unidos pelo alcance da morte no amor. Tal morte, que é sempre dobrada no separar-se aquilo que está essencialmente unido, gera saudades ou "sentimentos", pois, como se verifica na Fênix Renascida, podem intitular-se também Sentimentos os poemas que cantam os infortúnios que desuniram os corpos, não as almas, de tristes amantes, como aqueles Sentimentos de D. Pedro e D. Inês de Castro que teriam sido compostos por Manoel de Azevedo Pereira. ${ }^{484}$ Inclusive aquelas Saudades de Lídia e Armido, atribuídas a Bacelar na Fênix Renascida, ${ }^{485}$ são intituladas, em diversos manuscritos indicados por Mafalda Ferin Cunha, ${ }^{486}$ Sentimentos de Lídia, ressaltando-se sempre que "sentimento", na lírica seiscentista, é a "pena que se toma de alguma coisa", 487 ou seja, é a dor, no caso de Lídia e Armido, amorosa. Essa dor ou esses sentimentos, exprime-os, agudamente sintetizados, Lídia na seguinte oitava dessas Saudades ditas de Bacelar:

Em fim partes-te Armido, em fim se parte

De meus olhos a luz, do peito a vida,

Em fim trocas, cruel, amor por Marte,

Deixas-me em fim a vida repartida;

Não me leves, tirano, ũa só parte,

\footnotetext{
483 Idem, p. 189.

${ }^{484}$ A Fenix Renascida. Tomo I. $2^{\text {a }}$ impressão (1746), op.cit., pp.92-139.

${ }^{485}$ Idem, pp.77-90.

${ }^{486}$ Obras poéticas de António Barbosa Bacelar, op.cit., p.223.

${ }^{487}$ Bluteau, R. Vocabulario Portuguez, \& Latino, op.cit., volume 7, verb. “sentimento”, p.189.
} 
Leva estoutra, que fica dividida,

Fica de balde cá que amor ordena

Que em vez de vida me alimente a pena. ${ }^{488}$

Os equívocos são abundantes nesses versos, explorando-se diversas significações do termo "partir" e de seus derivados. Parte, enfim, Armido para a guerra, mas vai dividido (ou partido), porque se separa de Lídia que nele vive, e vivendo também aquele nesta, perde a dama a luz de seus olhos e a vida de seu peito. Partindo Armido, fica Lídia repartida, sem sua outra metade, restando-lhe apenas a parte que, sem luz nos olhos e vida no peito, ainda obedece ao amor e alimenta o constante penar; sobra-lhe, portanto, somente uma vida dividida ou uma morte viva em que consistem suas saudades ou sentimentos.

Tratando dessa mesma partida, mas falando dessa vez Armido, são ainda mais agudas, e bastante difíceis, as seguintes oitavas daquelas Saudades de Lídia e Armido que teriam sido compostas por Bernardo Ravasco:

Com tigo fico, e vou tambem comigo

neste êrro inevitavel de apartarme:

Vê que modo taõ nunca usado sigo, por naõ deixarte a ty, por naõ deixarme?

Levarme a mim, e não ficar com tigo, éra mais impossivel que ficarme:

julgo logo, se he mais ir quando fico;

pois, por naõ me apartar, me multiplico?

Tirana sutileza he esta ausencia, que vá comigo, que com tigo assista; pois dobro a pena, e nego a resistencia ao novo effeito que esta dor alista:

Que a saudade ao partir doce excelencia, ao ficar substituê ausente a vista; e eu dando injusto alento á crueldade, fico sem vista, parto sem saudade.

\footnotetext{
${ }^{488}$ Obras poéticas de António Barbosa Bacelar, op.cit., pp.224-225.
} 
Porque me fico, parto sem saudade;

porque me parto, he certo que naõ vejo;

e aquella he mais cruel penalidade

onde a presensa he véo do seu desejo:

Ser alivio levala, he falsidade,

pois nesse alivio, nova dor elejo;

que levar a saudade na presensa,

he das dores a dôr que he mais intensa. ${ }^{489}$

Os versos antitéticos dessas oitavas concretizam a contradição do partir-ficar amoroso. Como define Lausberg, "el antitheton es la contraposición de dos res opuestas. Las res contrapuestas pueden expresarse lingüísticamente mediante palabras aisladas, grupos de palabras o frases enteras". ${ }^{490}$ As res, partir e ficar, são de tal forma contrapostas nesses citados versos que se confundem, originando impossíveis lógicos que, irracionais, intensificam a dor amorosa que já é a mais intensa: a de levar-se a saudade na presença. Num erro inevitável de apartar-se, se Armido parte, com Lídia fica, mas sempre estarão divididos quando separados, porque, amantes, confundem-se. ${ }^{491}$ "Tirana sutileza" é essa ausência amorosa: como o amante leva a amada consigo e com ela fica, sofre uma ausência na parte que com ele vai e outra na parte que com ela fica. Dobra-se, dessa maneira, a pena e surge um "novo efeito": se sentir saudade, ao partir-se, é "doce excelência" e é ela substituída, ao ficar-se, pela vista, Armido fica sem vista e parte sem saudade, pois a saudade está na sua ausente parte que fica em Lídia e com a outra, presente, que se aparta não pode ver Lídia. Daí sofrer aquele amante, na presença amada, uma inopinada saudade que é a mais intensa dor, síntese do antitético partirficar.

Ouvindo embora as súplicas amorosas de Lídia, Armido parte, obedecendo ao fado e "contra as leis do desejo", para cumprir suas obrigações marciais. ${ }^{492}$ Distancia-se,

\footnotetext{
${ }^{489}$ Saudades de Lidia, e Armido, op.cit., pp.200-201.

${ }^{490}$ Lausberg, H. Manual de retórica literária. T.2, op.cit., p.210.

491 "Como de ambos unidos, se compunha / aquella vida, que a ambos animava; / entre os olhos a morte se dispunha, / que mais tiranamente os apartava: / Mas a causa, que nelles se propunha, / de tal modo a sentila os transformava; / que duplicando as almas, e os gemidos, / duas Lidias a chóram, dous Armidos." (Saudades de Lidia, e Armido, op.cit., p.188).

492 "Ficate Lydia embora, que he chegado / (lhe diz Armido) o tempo q. he preciso / deixar de verte, e obedecer ao fado, / contra as leis do desejo, e do juizo: / A vida aceita neste naõ logrado / abrasso, em que te dá seguro aviso / hum coraçaõ, que se viver aspira, / he porque tenha o mal aonde mais fira. // Armido, emfim, se parte morto, e triste; / e Lidia, emfim, se fica outra vez morta: / Nem Lidia ás ancias da sua dôr resiste; / nem os lassos Armido á pena corta: / A dor que he grande, athé no alivio assiste; /
} 
então, a Armada que, navegando pelo Tejo, segue seu destino bélico. ${ }^{493}$ Desolada, "sóbe se Lidia entaõ, cega, a hũ rochedo, / que no mar debrussado, em sy se tinha; / e êntre as consultas de valor, e mêdo, / resolve que matarse, só convinha". No entanto, "naõ quis dar ao mar a triste vida, / sem dar ao vento a extrema despedida". ${ }^{494}$ Assim, sobre o rochedo e diante do mar em que não se veem mais as naus que levam Armido, Lídia, antes de matar-se, lamenta sua triste vida sem seu ingrato e cruel amado:

Nilos os olhos, e Vesûvio o peito me viste, fero Ingrato, e te ausentaste; nem a incendios tiveste algum respeito; nem aos deluvios termo algum goardaste:

E se o meu coraçaõ vendo desfeito em fogo, e agoa; o teu nunca abrasaste; que lagrimas, já podem, que suspiros reduzirte (cruel) de teus retiros?

Quantas vezes queria naõ quererte, só por poder assim mais adorarte? Agora, só suspiro poder verte, e naõ vale a meus olhos suspirarte:

Oh quem cuidára, Triste, que a perderte chegára nunca o extremo de ausentarte! Mas se he teu gosto amar o mar, e o vento, quero querer por gosto esse tormento.

Se por tỹ choro, se por tỹ suspiro, nem assim modefico o meu tormento; que como padecer somente aspiro, no mesmo alivio dóbro o sentimento:

E se no fogo de meus ays respiro, e na agoa de meus olhos tomo alento;

nenhum remedio á sua mágoa importa; / porque excede obstinada nas porfias / destas duas discretas tiranias." (Idem, p.203).

493 "Foy carpando, e surgindo toda a Armada / da Capitánia o rumo, e cortesias; / pouco a pouco se vai vendo afastada, / e ouvindo mal das Tubas as porfias: / Já Bellem pássa, e deixa a doce estrada, / que ennobrecem do Tejo as ondas frias; / e as Campanhas sulcando do occeano, / todas as Naos largavam todo o pano." (Idem, p.207).

${ }^{494}$ Idem, p. 209. 
he por ter contra mim nos meus sentidos,

o fogo, e a agoa a teu favor unidos. ${ }^{495}$

Na primeira dessas oitavas, queixa-se Lídia contra o "fero ingrato" Armido, por ter ele se ausentado mesmo tendo visto os incêndios do "Vesúvio-peito" da amada e os dilúvios de seus "Nilos-olhos". Desse modo, fogo e água, suspiros e lágrimas, serão os conceitos centrais desenvolvidos nessas três coplas. Da queixa contra o cruel amado, na primeira, passa-se, na segunda, ao lamento da triste condição da amante que, muitas vezes, quis não querer Armido só para poder assim adorá-lo ainda mais. Agora, estando ele ausente, ela só sabe suspirar, inutilmente, para poder vê-lo. Contudo, surpreendentemente, Lídia aceita sua lastimosa condição, já que se Armido, por gosto, ama o mar e o vento e, portanto, a água dos olhos e os suspiros do peito da amanteamada, esta, também por gosto, quer esse tormento: da mesma forma que as vidas dos amantes, confundem-se suas vontades. Portanto, como se lê na última oitava citada, são inúteis o choro e o suspiro de Lídia, pois assim fazendo ela aspira somente ao padecimento, dobrando nesse suposto alívio seu sentimento, sua dor: se no fogo de seus “ais" ela respira e na água de seus olhos toma alento, visto que sua vida de ausência amada se alimenta de tormento, suspira e chora Lídia não para aliviar seus males, mas para ter contra si própria, dobrados e unidos a favor de Armido, aquele fogo do Vesúvio e aquela água dos Nilos.

Antes de jogar-se do rochedo ao mar, Lídia não condena Armido pelo sofrimento que padece, e sim a si mesma, ou melhor, ao seu excessivo "querer":

Mas já, oh Armido meu, te naõ condeno,

que eu tive a culpa toda deste engano;

fôra o meu damno o teu desejo ameno;

o meu querer, teu gosto nesse dano;

e logo fôra gloria quanto peno,

felicidade o mesmo desengano;

pois discreto teria o meu tormento,

no teu arbitrio o seu merecimento.

Bem justamente, logo arrependida

sinto a dor, que só sinto de naõ darte

${ }^{495}$ Idem, pp.218-219. 
nos ultimos abrassos, ésta vida,

que naõ teve mais ser, do que adorarte:

E se o desmayo de que fui rendida,

fez, que sem verte, fosses embarcarte;

fará agora o valor, que amante acerte

embarcarme em mim mesma, por îr vêrte. ${ }^{496}$

Se fosse discreto o tormento de Lídia, isto é, se fosse comedido o seu querer, seria devidamente correspondido pelo "desejo ameno" de Armido, tendo, assim, no arbítrio do amado seu merecimento. Porém, Armido partiu com a Armada, cumprindo seu dever, atendendo à razão, e deixou Lídia com seu excessivo e solitário tormento de amor. Amante desmesurada, ela sente e age contra a razão: a sua dor não é culpa do cruel e ingrato Armido que a abandonou e nem é mais aquela da ausência amada; padece essa dama devido às exigências de um amor desmedido, cuja cega justiça faz com que ela, mesmo sofrendo pela ingratidão de Armido, lamente (aumentando sua dor) não poder morrer nos braços amados. Isso porque, uma vida amante não tem outro propósito a não ser adorar cegamente. Lídia se perdeu desde o momento em que seu amado embarcou na nau; reencontrar-se, ausente Armido, é impossível em vida: restalhe, então, guiada pelo seu valor amante, a esperança de revê-lo após a morte, embarcando em si mesma, pois lá sempre estará vivo seu adorado Armido.

Essa fineza do agudo amor da lírica seiscentista, que se faz doloroso conflito na ausência do ser amado, é convenção das mais caras a essa concepção amorosa, e que muito deve à imitação da lírica camoniana. Vale citar, nesse sentido, o seguinte soneto atribuído a Bacelar, intitulado "A uma ausência":

Sinto-me sem sentir todo abrasado

No riguroso fogo que me alenta,

O mal, que me consome, me sustenta,

O bem, que me entretém, me dá cuidado.

Ando sem me mover, falo calado,

$\mathrm{O}$ que mais perto vejo se me ausenta

E o que estou sem ver mais me atormenta,

Alegro-me de ver-me atormentado.

Choro no mesmo ponto em que me rio,

${ }^{496}$ Idem, pp.227-228. 
No mor risco me anima a confiança,

Do que menos se espera estou mais certo.

Mas se de confiado desconfio

É porque entre receios da mudança

Ando perdido em mim, como em deserto. ${ }^{497}$

Como apontado por Mafalda Ferin Cunha, na epígrafe da lição de um dos manuscritos em que se encontra esse poema, é ressaltado que se trata de uma glosa do verso de Camões “Ando perdido em mim como em deserto". Além disso, são nítidos os ecos do soneto camoniano Tanto de meu estado me acho incerto. ${ }^{498}$ Essas antíteses camonianas estão, assim, na própria constituição do amor da poesia portuguesa do século XVII, cujas contradições, elaboradas retórica e poeticamente, exprimem, racionalmente, as desrazões do amor humano: amar desmesuradamente, como Lídia e Armido, é sempre andar perdido em si, como em deserto, porque é deixar morrer parte de si para embarcar-se no outro, em busca de uma completude que jamais se alcança em vida.

No discurso XLII de Agudeza y Arte de Ingenio, Baltasar Gracián destaca justamente a "agudeza por contradiccion, y repugnancia en los afectos, y sentimientos del animo", que consiste na "oposicion (...) de los sentimientos proprios, y afectos del animo". ${ }^{499}$ Citando um soneto de Manuel de Salinas e Lizana ${ }^{500}$ que, à semelhança daquele "A uma ausência" dito de Bacelar e do Tanto de meu estado me acho incerto camoniano, explora essa contradição ou oposição dos sentimentos e dos afetos, Gracián comenta que "muchas destas contradiciones conglobadas hazen un concepto plausible (...), y concluye con la exageracion de su sentimiento en vez de la razon". ${ }^{501}$ Fazer possível o impossível, mudar-se estando parado, gozar de liberdade sendo cativo, ver-se o invisível, desenredar-se enredando-se cada vez mais, são extremos da vida amante, em que o "sentimento amoroso" (aqui entendido como dor, penar ou tormento) é exagerado em detrimento da razão.

\footnotetext{
${ }^{497}$ Obras poéticas de António Barbosa Bacelar, op.cit., p.652.

498 Idem, ibidem.

${ }^{499}$ Gracián, B. Agudeza y Arte de Ingenio, op.cit., p.276.

500 "Cuitado que un punto lloro y rio, / espero, quiero, temo, y aborrezco, / juntamente me alegro, y entristezco, / de una cosa confío, y desconfío. // Vuelo sin alas, estando ciego guio, / en lo que valgo más, menos merezco, / callo, doy voces, hablo, y enmudezco, / nadie me contradice, y yo porfío. / Querria hacer posible lo imposible; / querria poder mudarme, y estar quedo, / gozar de libertad, y estar cautivo. // Querria que se viese lo invisible, / querría desenredarme, y más me enredo, / tales son los extremos en que vivo."

${ }^{501}$ Idem, p. 279.
} 
Por isso, Lídia sofre, decorosamente, na sua condição de amante desarrazoada, cujo amado abandonou-a, indecorosamente, seguindo as leis da razão. Mal acabado seu discurso ao vento, Lídia "do rochedo no mar se precipita". Com a sua morte, "entristeceusse a mesma natureza, / da formosura rottos os modellos: / Lamanetávam as Fontes, Aves, Flores, o Deos sem vista, a Deosa dos amores”. E foi justamente essa deusa dos amores, Vênus, que quis que Lídia ficasse eternizada, propondo a Júpiter que transformasse essa triste amante em "estrela fixa", o que ele concedeu "e n'um momento, do profundo a traslada ao Firmamento". Julga-se, então, o trágico fim da dama:
Extremos de juiso, e formosura, sempre foram letal veneno á vida; contra o seu ser, o só portento dura, que a fortuna he das partes homicida: O excesso mais discreto da Loucura, he de Amor a finesa mais valida: sendo pois Lidia taõ discreta, e bella, Estrella póde ser, naõ pôde têlla. ${ }^{502}$

A maior fineza desse amor é, enfim, o excesso mais discreto da loucura. Como já destacado, fineza, no século XVII, pode ser entendido tanto como agudeza quanto como ação de galanteria ou de cortesia, sendo que essa segunda acepção remete ao fin'amor da lírica trovadoresca. Dessa maneira, a fineza do amor da lírica seiscentista é uma aguda arte de amar, cujos procedimentos retórico-poéticos procuram imitar da loucura o seu excesso mais discreto, principalmente com metáforas, antíteses e hipérboles que fazem da razão o seu instrumento mais louco, em que ressoam, entre outras, aquelas controversas "rimas sonoras" da zampoña gongórica:

Estas que me dictó rimas sonoras, culta sí, aunque bucólica, Talía - ¡oh excelso conde! -, en las purpúreas horas que es rosa la alba y rosivler el día, ahora que de luz tu Niebla doras, escucha, al son de la zampoña mía,

\footnotetext{
${ }^{502}$ Saudades de Lidia, e Armido, op.cit., p.233.
} 
si ya los muros no te ven, de Huelva,

peinar el viento, fatigar la selva. ${ }^{503}$

Ditadas pela musa da comédia, culta, conquanto bucólica, essas "rimas sonoras" não ignoram o decoro dos gêneros poéticos, mas fazem da mescla deles um novo e difícil canto, entoado ao som da inusitada zampoña. Essa aguda mescla, como já se ressaltou, é polêmica na produção retórico-poética do século XVII; contudo (ou por isso mesmo), é, ao mesmo tempo, uma das principais fontes de imitação. E tais imitações se dão, na sua maioria, justamente na poesia lírica, tornando esse gênero que, como destacado no primeiro capítulo deste estudo, é de difícil definição nos anos Seiscentos por não contar com uma preceptiva poética unívoca e específica - ainda mais amplo e complexo, ou seja, ainda menos definível. Daí a importância da caracterização de uma de suas principais matérias: o amor, que se constituindo nessa ampla e variada lírica, é essencial para a constituição de sua vertente amorosa. Amor que se faz novo imitando agudo amores vários.

E assim é aquele amor de Lídia e Armido. Morta a dama, transformada em estrela por Júpiter, a pedido de Vênus, navega o infeliz mancebo, sem saber desse fatal destino da amada, "posto no bombordo / que da parte da terra lhe ficava", padecendo "as saudades da Prenda que deixava; / dando êntre as ancias de chamar por ella, / mais agoa ao fogo, mais alento á véla." Entoa Armido, então, um longo e solitário lamento, arrependido pelo seu engano de deixar Lídia e desesperado pelo seu triste fado. Engano e fado serão, assim, os principais conceitos desse lamento, desenvolvidos agudamente a partir da estância 119 e que se concluem numa intrincada lógica amorosa:

Perdite, ou por engano do juizo,

ou por culpa do fado que o domina:

do fado, porque faz mais indeviso

o amor, que na presensa mais declina:

do juizo, por crêr que éra preciso

naõ te ver para amarte mais divina;

mas veyo a ser no effeito em tudo errado,

engano amarte mais; mais vêrte, fado.

${ }^{503}$ Góngora, L. de. Fábula de Polifemo y Galatea. Edición de Alexander A. Parker. Madrid: Cátedra, 2007, p.133. 
Mas se fôra do fado acçaõ naõ verte,

podéra sentir menos o deixarte;

que a violencia do fado, emfim preverte

do mais astuto a morte, a forsa, e arte:

E se eu te deixo só por mais quererte,

e he o meu naõ verte mais, mais adorarte;

porque culpo o naõ verte, naõ culpado?

para que digo, q̃. o naõ verte he fado?

Tambem se amarte mais engano fôra, naõ te adorára de mim mesmo ausente:

ver, e adorar, he premio do que adora;

que he gloria do adorar estar presente:

Mas adorar sem ver, tanto melhora

a fé, que faz o amor mais excellente;

sendo este modo pois taõ soberano,

amarte mais, naõ póde ser engano.

Logo, se o engano, e fado, que eu culpava, mayores culpas contra mim fabricam; aquelle amor, e vida, que eu lograva, na primeira innocencia as qualificam:

Naõ conhecia a gloria que gozava, e éstas mágoas agora o certeficam; porq̃. ignorava, entre o gozo, e riso, que coisa era viver no Paraîso. ${ }^{504}$

O "fado", segundo uma das significações apresentadas por Bluteau (a primeira que aparece em seu Vocabulário), é a “disposiçaõ, ou connexaõ das causas segundas, que a vontade de Deos tem determinado desde a eternidade, para tudo o que necessariamente há de succeder no mundo", ${ }^{505}$ derivando-se tal palavra do fatum latino. Além disso, é válido salientar que o mesmo Bluteau define "destino" como "o fado, \& a sorte de cada hum, que naõ he outra cousa, que a serie, \& ordem, com que a Divina

\footnotetext{
${ }^{504}$ Saudades de Lidia, e Armido, op.cit., pp.241-242.

505 Bluteau, R. Vocabulario Portuguez, \& Latino, op.cit., volume 4, verb. “fado", pp.13-14.
} 
providencia faz, que as cousas infallivelmente succedem. Fatum, i. Neut. Vid. Fado". 506 São, portanto, sinônimos esses dois vocábulos. Dessa forma, seja fado ou destino, essa noção, glosada nas citadas oitavas das Saudades de Lídia e Armido e definida no Vocabulário Português e Latino, pode ser mais bem compreendida tendo em vista a já mencionada filosofia estoico-cristã dos séculos XVI e XVII. Isso porque, na maior parte das discussões sobre o fado ou o destino entre as autoridades antigas, como Cícero no De Fato, já se dialogova, frequentemente, com concepções estoicas acerca desse assunto. E, posteriormente, nos séculos XVI e XVII, em particular, os debates filosóficos e teológicos a respeito das relações entre fatum, fortuna e providentia serão uma constante, devido, em grande medida, à necessidade de uma assimilação cristã de noções pagãs, exercendo, por exemplo, a leitura cristã do De Providentia de Sêneca um papel importante nesse sentido.

Desse modo, Justo Lípsio, um dos principais expoentes da doutrina estoicocristã, em seu já referido tratado De Constantia (especificamente, a partir do capítulo 13 do livro I), discute a concepção de providência, que implica o fatum e o livre-arbítrio. ${ }^{507}$ Para Lípsio, há, então, quatro formas de combater os males públicos: pensar que eles são enviados por Deus, que são necessários por causa do destino, que são úteis ou que não são perniciosos nem novos ou surpreendentes. Para que esses motivos possam consolar, é preciso, antes, admitir-se a existência de Deus e de sua providência. Esta é o cuidado divino, vigilante e perpétuo, pelo qual ele vê tudo, está em tudo e conhece tudo, conduzindo e governando todas as coisas através de uma ordem imutável, que os homens não conhecem. ${ }^{508}$ Com exceção do pecado, nada acontece que não tenha origem em Deus. Por isso, Lípsio afirma, citando Sêneca, que a verdadeira liberdade consiste na

\footnotetext{
${ }^{506}$ Idem, volume 3, verb. "destino", p.176.

${ }^{507}$ Vale lembrar que, antes de Lípsio, Santo Agostinho, questionando a noção estoica do fatum, segundo a qual seria o destino aquilo que determinaria todas as coisas que acontecem, inclusive, as "coisas divinas", buscou coadunar a vontade e a liberdade humanas com a presciência divina (que não está predeterminada por nada além da própria vontade de Deus): "Non est autem consequens, ut, si Deo certus est omnium ordo causarum, ideo nihil sit in nostrae uoluntatis arbitrio. Et ipsae quippe nostrae uoluntates in causarum ordine sunt, qui certus est Deo eiusque praescientia continetur, quoniam et humanae uoluntates humanorum operum causae sunt; atque ita, qui omnes rerum causas praesciuit, profecto in eis causis etiam nostras uoluntates ignorare non potuit, quas nostrorum operum causas esse praesciuit." (De Ciuitate $D e i, \mathrm{~V}, \mathrm{IX})$. Esse trecho de Santo Agostinho é traduzido da seguinte forma por J. Dias Pereira: "Mas pelo facto de a ordem das causas estar determinada para Deus, não se conclui que nada depende do arbítrio da nossa vontade. É que as nossas próprias vontades pertencem à ordem causal, certa para Deus e contida na sua presciência. As vontades humanas são efectivamente as causas das acções humanas, e por conseguinte aquele que previu todas as causas das coisas não pôde ignorar, entre as causas, as nossas próprias vontades, pois que previu as causas das nossas acções" (A Cidade de Deus. Tradução, prefácio, nota biográfica e transcrições de J. Dias Pereira. $2^{a}$ ed. Lisboa: Fundação Calouste Gulbenkian, 1996, p.489).

${ }^{508}$ De Constantia, I, 13.
} 
obediência a Deus: "In regno nati sumus, deo parere libertas est" (De Vita Beata, XV, 7). ${ }^{509}$ Todavia, vale ressaltar que embora no texto de Lípsio essa frase de Sêneca seja usada como se tivesse sido escrita por um autor cristão, é evidente que o "deus" de que fala o filósofo cordovês não é o Deus cristão, pois os deuses gregos e romanos estão subordinados à Moira e ao Fatum, ao passo que o Deus dos cristãos é absoluta liberdade refletida na luz da graça que ilumina o livre-arbítrio humano.

As considerações a respeito da segunda forma de se combater os males públicos levam a um debate explícito com a filosofia estoica, motivado pela noção de fatum. A discórdia principal se assenta no fato de que, para os estoicos, deus também estaria sujeito ao destino, como Crisipo e Sêneca teriam-no afirmado. Eis o que diz o segundo: "quidquid est quod nos sic uiuere, sic mori iussit, eadem necessitate et deos alligat. Inreuocabilis humana pariter ac diuina cursus uehit. Ille ipse omnium conditor et rector scripsit quidem fata, sed sequitur; semper paret, semel iussit" (De Providentia, V, 8). ${ }^{510}$ Já para Lípsio, o fatum é o que Deus disse e comandou e, portanto, está submetido à vontade divina. É fundamental distinguir a providência e o destino: aquela é uma força (universal e indivisível), que está em Deus, de ver, saber e governar tudo; enquanto o fatum "desce" sobre todas as coisas e é considerado em cada uma delas, sendo uma divisão da providência, distintamente repartida. Enfim, a providência está em Deus e é atributo apenas dele; o destino está nas coisas e é apropriado somente a elas. ${ }^{511}$

No capítulo 20 do livro I do De Constantia, o fatum estoico, em específico, é amplamente discutido e contraposto às "verdades cristãs". O destino verdadeiro (ou seja, cristão) é distinguido do estoico, pois: $1^{\circ}$ ) Os estoicos submetem Deus ao destino, mas, em termos cristãos, o destino é que está submetido à divindade; $2^{\circ}$ ) Os estoicos atribuem eternidade a um fluxo e sequência de causas naturais, já os cristãos acreditam que as causas segundas não são nem eternas nem nascidas com o mundo; $3^{\circ}$ ) A doutrina estoica, diferentemente da cristã, subtrai de todas as coisas o contingente e o fortuito; e $4^{\circ}$ ) Os filósofos da Stoa "forçam" a vontade humana, enquanto na filosofia cristã o destino e a liberdade da vontade humana estão perfeitamente conciliados. Assim, são essas as divergências centrais entre as duas doutrinas. A partir dessa diferenciação é que

\footnotetext{
${ }^{509} \mathrm{Idem}, \mathrm{I}, 14$.

${ }^{510}$ Idem,I, 18. O trecho citado do De Providentia é traduzido por Ricardo da Cunha Lima da seguinte maneira: "Seja o que for que nos ordenou a viver assim, a morrer assim, sob a mesma imperiosa necessidade, ata também os deuses. Um fluxo irrevogável tranasporta de modo igual as coisas humanas e divinas: o próprio criador e condutor de todas as coisas escreveu, sem dúvida, os fados, mas os segue. Para sempre obedece, uma vez ordenou" (Sobre a Divina Providência. Tradução, introdução e notas de Ricardo da Cunha Lima. São Paulo: Nova Alexandria, 2000, p.57).

${ }^{511}$ De Constantia, I, 19.
} 
se pode afirmar que o destino é a primeira causa, que, no entanto, não elimina as causa segundas, entre as quais está a vontade humana. Por isso, peca-se livremente e também necessariamente, porque, com o livre-arbítrio, pode-se aceitar ou não a disposição divina, mas sem jamais lhe resistir ou impedi-la. ${ }^{512}$

Essa concepção estoico-cristã do fatum contribui para a discussão daquele "fado", desenvolvido como conceito agudo nos citados versos das Saudades de Lídia e Armido atribuídas a Bernardo Ravasco. Dessa forma, Armido afirma, inicialmente, ter perdido Lídia, ao deixá-la para se integrar à Armada e ir à guerra, por um dos dois seguintes motivos: por um engano do juízo - isto é, por um erro de julgamento, por uma escolha equivocada - ou por culpa do fado que domina o próprio juízo, determinando suas escolhas. À semelhança das discussões da doutrina estoico-cristã, Armido questiona se seu erro foi devido ao livre-arbítrio humano ou ao destino, ou melhor, ao fatum que predeterminaria, infalivelmente, todos os acontecimentos. Em termos amorosos, o fado seria culpado por fazer o amor indivisível naqueles que amam e, por isso, não poderia ser compartilhado com a presença amada, perdendo sua força; já o engano do juízo foi crer que, para amar mais divinamente a amada, era preciso não vêla. Entretanto, o resultado do afastar-se Armido de Lídia não foi o esperado, invertendose os efeitos do fado e do juízo no verso final da oitava que condensa agudamente a confusão amante de Armido ("engano amarte mais; mais vêrte, fado"): ele se enganou ao afastar-se de Lídia, pois é impossível amá-la ainda mais; e querer mais ainda vê-la, agora que já não pode, é seu doloroso fado.

Nas três oitavas seguintes, exploram-se, engenhosamente, as consequências lógicas, que de tão intrincadas parecem ilógicas, da ação do fado e do engano do juízo no erro amoroso de ausentar-se o amante, voluntariamente, da presença amada. Se fosse desígnio do fado não ver mais Armido a Lídia, poderia sofrer menos o amante ao deixála, uma vez que o fatum, numa estrita perspectiva estoica, determinaria todas as coisas, inclusive a vontade humana e sua suposta liberdade de escolha. Porém, em termos estoico-cristãos, como se salientou, é necessário o livre-arbítrio, pois, caso contrário, não haveria pecado ou teria ele origem em Deus (dois absurdos indefensáveis). Assim, o pecado amoroso de Armido não se deve à "violência do fado", mas à sua equivocada opção, guiada por seu livre juízo, de deixar Lídia para mais querê-la e não mais vê-la para mais adorá-la. Então, não é o padecimento do amante culpa do não se ver a amada,

\footnotetext{
${ }^{512}$ Idem, I, 20.
} 
já que não vê-la não é fado, e sim (foi) isenta escolha. Não foi engano também querer Armido amar ainda mais Lídia, visto que, se o fosse, não a adoraria como se estivesse dele próprio ausente (transformado que está, enquanto amante, na amada). Não foi, enfim, a sua partida um engano, porque "adorar sem ver, tanto melhora / a fé, que faz o amor mais excellente" e jamais poderia ser a excelência desse amor, ou melhor, dessa adoração um erro. Logo, como se observa na última oitava citada, conclusão desse difícil silogismo, Armido não pode culpar o fado nem o engano pela sua livre escolha de partir e, consequentemente, por suas saudades; as "maiores culpas" são dele próprio que, enquanto desfrutava aquele amor e vida junto a Lídia, "naõ conhecia a gloria que gozava, / e éstas mágoas agora o certeficam; / porq̃. ignorava, entre o gozo, e riso, / que coisa era viver no Paraîso". Sua ignorância amorosa fez com que ele, pecador cegado pelo gozo e pelo riso, expulsasse a si mesmo do paraíso do amor e se perdesse, justamente castigado, no inferno das saudades:

\footnotetext{
Já neste inferno, aonde nunca apágam nem mar as penas, nem o vento as chamas, meus nescios êrros castigados pagam ésta alma em agoas, este peito em flamas:

A minha vista a tua dor afagam aquellas que o cristal o sexo infamas, que hum, e outro remedio que festejo, saõ sombras do tormento q̃. em mim vejo. ${ }^{513}$
}

Sofrendo as devidas penas nesse inferno undoso, preso num "cárcere de pinho", em que as águas são corrente e o vento grilhões, atado às cordas e sujeito ao linho, Armido paga aquele seu delito de deixar Lídia com esse seu tormento de saudades. ${ }^{514}$ Mas decide pôr fim a tal tormento quando o "piloto vigilante" da nau em que estava percebe uma "resplandecente novidade" no céu e Armido, reparando nessa nova estrela, "escassamente de Lidia as sombras vê naquelles rayos". Desesperado por saber que sua amada, tornada estrela, estava morta, o saudoso e triste amante decide,

\footnotetext{
${ }_{514}^{513}$ Saudades de Lidia, e Armido, op.cit., p.243.

514 "Agora neste carcere de pinho, / corrente as agoas, e grilhoẽns o vento / atado ás cordas, e sogeito ao linho, / o meu delicto pago em meu tormento: / He prisaõ successiva este caminho, / onde sim tenho livre o pensamento; / e este me agrava a culpa de meus êrros, / e athé do vento, e mar me forja os ferros." (Idem, p.249).
} 
então, "dar docemente á vida descontente / fatal ecclipse a seus florîdos mayos, / supoẽm com sigo; e alî, com louco acordo, / ao mar se arroja do ceruleo bordo". 515

Mortos ambos os amantes, encerra e julga seus infortúnios amorosos a persona lírica que os narra, deleitando com agudas lições de amor:

Quando Armido no lenho se partia, quando Lidia na praya se ficava,

Lidia no lenho o objecto he $\tilde{\text { q. atendia, }}$ de sỹ Armido na praya se apartava: Aquella devisaõ que os desunîa, éra a uniaõ q̃. mais os transformava, clausulandose em tristes laberintos, indistinctos ao ser, e ávista extintos.

Ao mesmo tempo Lidia, e Armido déram nova vida aos dous corpos, q̃. animáram; pois se entre ambos as vistas se perdêram, êntre ambos as duas almas se trocáram: Ambos a mesma gloria apetecêram; ambos o mesmo fim multiplicáram: Ella, da rocha ao mar se precipita; Elle, do bordo sem imitala, a imita. (...)

Sentida Venus, e anojado Marte, unida pompa prevenira a Armido; segue funesto o belico Estendarte, roto o Arco do Deos já naõ seguido: Dos maritimos quasi a mayor parte; dos celestes o Deos mais preferido; Venus no mar o leva a Lidia bella, Marte nos Ceos a ser com Lidia Estrella.

O fim fatal de hũ, e de outro Amante, nas ondas, nas Estrellas se retrata:

\footnotetext{
${ }^{515}$ Idem, p.251.
} 
O Olimpo fixa em estrellas de diamante;

e o Occeano em laminas de prata:

Ambos ûne a fortuna sempre errante;

ambos anima a fama nunca ingrata,

authorizando em luzes essas palmas,

Neptuno os corpos, Jupiter as almas. ${ }^{516}$

Na primeira estância referida, glosa-se aquela repisada confusão dos amantes, que é condição do amor: Armido partiu na nau enquanto Lídia ficou na praia, mas, confundidos, ela, na nau, é que olhava atentamente o "objeto" que ficava e ele, na praia, de si próprio se apartava. Assim, a divisão que desune os amantes é a união que mais os transforma; e ausentar-se no amor é clausular-se em tristes labirintos, pois, indistintos ao ser, amante é amada e amada é amante, porém, estando um(a) no(a) outro(a) transformados, distantes, não se veem a si mesmos. Por isso, na segunda estância mencionada, afirma-se que Lídia e Armido deram nova vida aos dois corpos que, mortos na ausência amada, animaram trocando-se as duas almas amantes: sem se ver, não souberam mais quem fosse Lídia e quem Armido. Daí ser a glória de um(a) a glória de outra(o) e o fim fatal de ambos multiplicado: se ela se jogou da rocha ao mar, ele, sem o saber, imita-a porque nela se confunde, jogando-se do bordo da nau ao mesmo mar.

Essa transformação amorosa retrata-se, nas duas oitavas finais do poema, nas metamorfoses de ambos os amantes tornados estrelas: Vênus, nascida no mar, leva Armido, que a respeitou por morrer de amor, até os céus para que Marte, a quem o rapaz honrou integrando a Armada, faça dele também estrela como Lídia. Essas transformações ou metamorfoses, tomadas como agudos conceitos amorosos, são cantadas com estilo culto, à semelhança daquele gongórico que relata, no final da Fábula de Polifemo y Galatea, a metamorfose de Ácis que, esmagado pela imensa rocha que sobre ele lançou o apaixonado Polifemo, é acolhido pela mãe de Galateia, Dóris, que, com piedoso pranto, o saúda como a genro e o aclama como a divindade, pois foi transformado em rio:

Con vïolencia desgajó infinita,

la mayor punta de la excelsa roca,

${ }^{516}$ Idem, pp.253-256. 
que al joven, sobre quien la precipita, urna es mucha, pirámide no poca.

Con lágrimas la ninfa solicita

las deidades del mar, que Acis invoca:

concurren todas, y el peñasco duro

la sangre que exprimió, cristal fue puro.

Sus miembros lastimosamente opresos

del escollo fatal fueron apenas,

que los pies de los árboles más gruesos

calzó el líquido aljófar de sus venas.

Corriente plata al fin sus blancos huesos,

lamiendo flores y argentando arenas,

a Doris llega, que, con llanto pío,

yerno lo saludó, lo aclamó río. ${ }^{517}$

Dessa forma, naquela oitava final das Saudades de Lídia e Armido, o fim fatal dos dois amantes é retratado, nas ondas e nas estrelas, por um estilo culto que faz deles "estrelas de diamante" do Olimpo, polidas pelas "lâminas de prata" do Oceano. Assim unidos pela "fortuna sempre errante" e eternamente animados pela "fama nunca ingrata", é, contudo, o agudo canto que os imortaliza dando a essas "palmas" amorosas luminosa autoridade, mais ainda que Netuno a seus corpos e Júpiter a suas almas.

De agudos cantos como esse se faz o amor da lírica seiscentista. Amor assim agudo é também feito de finezas: uma difícil arte de amar que ensina como entoar a coita e a alegria amorosas em cantos escritos. Nessa arte, preceitua-se, embora sem regras precisas, que o ser amado o é por ser perfeitamente belo e bom, mas essa beleza e bondade jamais podem ser alcançadas pelo imperfeito amor humano, que sempre deseja o que nunca apreende. No intrasponível (ao menos em vida) caminho entre o que se deseja e o que se alcança, as agudezas amorosas deleitam e ensinam: elas se mostram como saborosos frutos cujo sabor ou, segundo Góngora, cuja "educação" advém de um árduo trabalho do entendimento que aviva o engenho. E o díficl fruto amoroso da aguda poesia seiscentista se cultiva entre imitações de diversos amores. Do fin'amor da lírica trovadoresca, como se demonstrou, imitam-se muitos de seus preceitos e, por vezes, sua

${ }^{517}$ Góngora, L. de. Fábula de Polifemo y Galatea, op.cit., p.155. 
peculiar música; porém, tudo ressoa como em labirintos escritos para tornar agudo o amor. Esses e outros ecos amorosos repercutem na lírica do século XVII, enfim, como saudades de um impossível amor: aquele que, perfeito e nunca experimentado, é modelo inesgotável de agudas imitações amorosas. 


\section{Considerações finais}

Percorridos seus principais aspectos, define-se, então, o amor agudo: matéria que se constitui na poesia seiscentista, é o que materializa sua lírica amorosa, cuja aguda imitação de canto entoa amores vários, movendo seus leitores pelo deleite e pelo ensinamento que, fazendo-se difíceis, buscam tornar ainda mais deleitosas e instrutivas essas imitações líricas de diversos amores. Ovidiano, cortês, petrarquista, camoniano, gongórico ou platônico, estoico, epicurista, cristão, é tal amor uma aguda mescla de diferentes concepções e preceptivas amorosas; mistura essa que é específico construto da poesia do século XVII, pois na produção retórico-poética dos anos Seiscentos é, justamente, a agudeza procedimento central e norte poético para o qual convergem aquelas preceptivas e concepções que, confundidas em agudo ponto, enformam um peculiar, porque fundamentalmente também agudo, amor. Assim, a "novidade" da lírica amorosa seiscentista é, em grande medida, fruto desse novo amor.

Nessa concepção poético-amorosa do século XVII, na qual se entroncam diversas outras, são fundamentais, como se observou neste trabalho, os contrários efeitos do amor, condensados, principalmente, no antitético topos da vida-morte amorosa. Vive-se e morre-se no amor, porque perfeitamente bela e virtuosa a amada, é condição do amante, sempre imperfeito, viver para aquilo e naquilo que ama, na esperança de que os rigores amados, que matam, imortalizem a dor. Portanto, a persona lírica amante é nada além de canto escrito, que vive e morre pela impossível amada, buscando imortalizar-se nas penas amorosas. Assim são, por exemplo, os "efeitos contrários do rigor de Anarda":

Anarda bela no rigor sofrido

Deseja a morte ao lastimoso peito,

Sem ver que em seu perigo a morte aceito,

Pois sempre vive Anarda em meu sentido:

Mas como o mortal golpe desabrido

Nunca experimenta um infeliz sujeito,

Morro somente de amoroso efeito,

Nunca morro do golpe pretendido. 
Teme em meu coração a Parca forte

O divino retrato, que convida

A meu peito amoroso imortal sorte.

De sorte pois, que em glória padecida

Anarda própria me deseja a morte,

Anarda própria me defende a vida. ${ }^{518}$

No citado soneto de Manuel Botelho de Oliveira, o rigor de Anarda é morte e vida da persona lírica, que aceita morrer pelo perigo de amar uma dama tão rigorosa, já que embora morra seu lastimoso peito, Anarda estará sempre viva em seu pensamento, em sua imaginação amante. Porém, um "infeliz sujeito" não morre em consequência de "mortal golpe desabrido", isto é, em decorrência do desprezo da virtuosa amada, e sim de "amoroso efeito", numa morte que é vida eterna, pois no coração amante está imortalizado o "divino retrato" amado. Por isso, essa persona lírica amante vive, ou melhor, canta em função de Anarda, gozando uma antitética "glória padecida": o rigor amado que mata é o mesmo que dá imortal vida ao peito amoroso, ou seja, eterniza seu canto de agudo amor.

Desse modo, como se lê numa oitava daquelas Saudades de Lídia e Armido, atribuídas a Bernardo Ravasco e discutidas no terceiro capítulo deste estudo, é uma das principais condições desse amor agudo, para torná-lo mais merecido e puro, o padecimento do amante que, como um sábio estoico-cristão, suporta toda dor, mas que, como um pecador epicurista, é guiado pelo prazer - tanto aquele (antigo) que advém da ausência de sofrimento quanto este que se desfruta no próprio padecimento:

Amar sem padecer, he grande dita;

mas dita, que não dá merecimento;

que a pureza do amor, mais se acredita

na ausencia, na firmeza, e no tormento:

Aquelle, que ser raro solicita,

sempre dá que lograr ao sofrimento;

e se ditosos nunca padecemos,

não dirás oque a nós nos merecemos $?^{519}$

\footnotetext{
${ }^{518}$ Oliveira, M. B. de. Poesia completa: Música do Parnasso, Lira Sacra, op.cit., p.29.

${ }^{519}$ Saudades de Lidia, e Armido, op.cit., p.198.
} 
Amar sem nunca padecer é felicidade indigna aos amantes. Quanto mais suportarem o sofrimento tanto mais eles se merecerão, purificando, assim, seu amor. Portanto, agudo é também (e fundamentalmente) o amor que almeja se purificar na ausência, na firmeza e no tormento, mostrando-se difícil na elocução por ser raro o conceito: peregrinas e humanas palavras em busca de impossível coisa divina. Mas palavras essas que se fazem coisas igualmente humanas: amante, amada e agudo amor que os une. Isso porque, como já se destacou no primeiro capítulo deste trabalho, a metáfora, considerada na Poética aristotélica fonte por excelência de ensinamento e deleite, por evidenciar a semelhança entre as coisas, é tomada no século XVII como fundamento da agudeza; e são mais agudas aquelas metáforas que acham uma tão intrincada correspondência entre diferentes "objetos" (sejam palavras ou coisas) que chegam a confundi-los. Assim, aquela semelhança aristotélica não se restringe mais às coisas ou às palavras que as nomeiam, sendo de tal forma explorada que as palavras e as coisas se misturam, como indica António José Saraiva acerca do "discurso engenhoso":

o texto e a coisa estão no mesmo plano. Passa-se de um a outro como se as aspas não exercessem função. Ora um texto é interpretado como coisa, ora a coisa como texto, ora um é o prolongamento do outro, ora eles se emaranham. De um texto extrai-se uma coisa; de uma coisa, uma palavra. As mesmas técnicas de análise verbal são válidas tanto para um como para outro. ${ }^{520}$

Isso decorre, especialmente, do fato de que, nos séculos XVI e XVII, a linguagem, dom dado por Deus, não é compreendida como um conjunto de signos independentes, mas como uma coisa da natureza. Tudo teve origem divina, coisas e signos. Quando a linguagem foi dada aos homens por Deus, ela era signo certo e transparente das coisas; porém, essa transparência foi destruída em Babel para punir os homens. "Mais si le langage ne ressemble plus immédiatement aux choses qu'il nomme, il n'est pas pour autant séparé du monde ; il continue, sous une autre forme, à être lieu des révélations et à faire partie de l'espace où la vérité, à la fois, se manifeste et s'énonce". 521 O sábio, então, deve interpretar a "natureza escrita" através dos

\footnotetext{
${ }^{520}$ Saraiva, A. J. O discurso engenhoso: estudos sobre Vieira e outros autores barrocos, op.cit., p.88.

${ }^{521}$ Foucault, Michel. Les mots et les choses: Une archéologie des sciences humaines. Paris: Gallimard, 2007, p.51.
} 
"comentários". Estes buscam restituir o plano uniforme das palavras e das coisas e revelar o texto primitivo ou primeiro que há sob a linguagem. Enfim,

Le commentaire ressemble indéfiniment à ce qu'il commente et qu'il ne peut jamais énoncer; tout comme le savoir de la nature trouve toujours de nouveaux signes à la ressemblance parce que la ressemblance ne peut être connue par elle-même, mais que les signes ne peuvent être autre chose que des similitudes. Et de même que ce jeu infini de la nature trouve son lien, sa forme et sa limitation dans le rapport du microcosme au macrocosme, de la même façon la tâche infinie du commentaire se rassure par la promesse d'un texte effectivement écrit que l'interprétation un jour révélera en son entier. ${ }^{522}$

No entanto, a linguagem, como coisa humana, é imperfeita e a interpretação, que depende dos signos (humanos), jamais revelará o texto primitivo. As formas perfeitas e imateriais da linguagem somente as possuem os seres mais elevados, como os anjos. Quanto aos homens, eles não podem ver face a face o original dos conceitos, sem a interpretação da "lingua mentitrice", como afirma Tesauro em seu Cannocchiale Aristotelico ao descrever "a comunicação angelical de conceitos": 523

Et questa Argutia Archetipa è quella, il cui protratto intendiamo di colorir nell'animo altrui per via de'simboli esteriori: non essendoci permesso de tramandarlo da spirito à spirito, senza il ministerio de'sensi. Et questa fù la sciocca rabbia di Socrate, incolpante la Natura del non havere aperto una finestretta in petto agli huomini, per veder faccia à faccia l'Originale de'lor concetti, senza interpretamento di lingua mentitrice; le cui traditioni souente son tradimenti. Contro alla qual querela potea compor la Natura il suo apologetico; rispondendo, ch'ella harebbe ad un tempo defraudato gli'nggnosi del diletto di tante belle Arti sermonali. L'Angelo adunque, \& l'Anima sgombra d'ogni corporeo impaccio; può senza mezzo effigiar nell'altro Spirito le spiritali imagini de'suoi pensieri; facendosi l'uno all'altro hor pittore, \& hor pittura; che è il corto, \& natural linguaggio degli Angeli. ${ }^{524}$

\footnotetext{
${ }^{522}$ Idem, pp.56-57.

${ }^{523}$ Cf. Carvalho, M. do S. F. de. Poesia de agudeza em Portugal, op.cit., pp.106-107.

${ }^{524}$ Tesauro, E. Il Cannocchiale Aristotelico, op.cit., cap. II, p.16.
} 
Essa concepção da linguagem tem como uma de suas principais fontes o $D e$ doctrina christiana de Santo Agostinho, ${ }^{525}$ sabendo-se que essa obra teve grande repercussão entre os tratadistas cristãos dos séculos XVI e XVII, como apontam Aníbal Pinto de Castro ${ }^{526}$ e Marc Fumaroli. ${ }^{527}$ Nos livros I e II do tratado de Agostinho são estudados, respectivamente, as coisas (res) e os signos (signa). Porém, logo no início do texto, há um trecho em que são feitas relevantes considerações sobre as res e os signa, assim como acerca de suas relações:

Omnis doctrina vel rerum est vel signorum, sed res per signa discuntur. Proprie autem nunca res appelavi quae non ad significandum aliquid adhibentur, sicuti est lignum lapis pecus atque huiusmodi cetera, sed non illud lignum quod in aquas amaras Moysen misisse legimus ut amaritudine carent, neque ille lapis quem Iacob sibi ad caput posuerat, neque illud pecus quod pro filio immolavit Abraham. Hae namque ita res sunt, ut aliarum etiam signa sint rerum. Sunt autem alia signa quorum omnis usus in significando est, sicuti sunt verba. Nemo enim utitur verbis, nisi aliquid significandi fratia. Ex quo intellegitr quid appellem signa, res eas videlicet quae ad significandum aliquid adhibentur. Quam ob rem omne signum etiam res aliqua est: quod enim nulla res est, omnino nihil est; non autem omnis res etiam signum est (De Doctrina Christiana, I, 2). ${ }^{528}$

\footnotetext{
${ }^{525}$ Para o texto latino, consultamos a seguinte edição: L'istruzione cristiana. A cura di Manlio Simonetti. Verona : Arnoldo Mondadori, 1994. E também consultamos a tradução para o português: A doutrina cristã: manual de exegese e formação cristã. Trad. Nair de Assis Oliveira. São Paulo: Paulus, 2002.

${ }^{526}$ Aníbal Pinto de Castro mostra, por exemplo, como um dos tratados que mais determinou a eloquiência cristã em fins do século XVI e no século XVII, a Rhetorica ecclesiastica de Luís de Granada, dependia, diretamente, das idéias do De Doctrina Christiana agostiniano, em particular, do livro IV. Eis uma das afirmações de Castro sobre as "dívidas" do tratado de Granada: "De entre todas estas dívidas são significamente vultuosas as que contraiu para com as obras de Quintiliano e Santo Agostinho" (Retórica e teorização literária em Portugal, op.cit., p.53).

${ }^{527}$ Fumaroli considera o De Doctrina Christiana (na verdade, seu livro IV) como a última retórica antiga e a primeira retórica eclesiástica (L'âge de l'éloquence, op.cit., pp.70-76).

${ }^{528} \mathrm{O}$ mesmo trecho é traduzido por Nair de Assis Oliveira da seguinte maneira: "Toda doutrina reduz-se ao ensino das coisas e ao dos sinais. Mas as coisas são conhecidas por meio dos sinais. Portanto, acabo de denominar coisas a tudo o que não está empregado para significar algum outro objeto como, por exemplo, uma vara, uma pedra, um animal ou outro objeto análogo. Não me refiro, contudo, àquela vara da qual lemos que Moisés atirou às águas amargas para diluir sua amargura $($ Ex 15,25). Nem à pedra que Jacó pôs debaixo da cabeça, como almofada (Gn 28,11). Nem àquele cordeiro que Abraão imolou no lugar de seu filho (Gn 22, 13). Esses objetos, de fato, são coisas, masnas circunstâncias mencionadas tornaram-se ao mesmo tempo sinais de outras coisas. Existem sinais, mas de outro gênero, cujo emprego selimita unicamente a significar algo, como é o caso das palavras (verba). Ninguém emprega as palavras a não ser para significar alguma coisa com elas. Daí se deduz que denomino sinais a tudo o que se emprega para significar alguma coisa além de si mesmo. É porque todo sinal é ao mesmo tempo alguma coisa, visto
} 
Para Santo Agostinho, toda doutrina são coisas e signos. Porém, as res só são “ditas" e, consequentemente, conhecidas através dos signa. A coisa não significa nada além de si mesma, a não ser em alguns casos excepcionais, como a "vara" de Moisés, a "pedra" de Jacó ou o "cordeiro" que Abraão imolou, que, apesar de serem res, tornaram-se também signa de outras coisas. Alguns signos, como as palavras (uerba), são empregados apenas para significarem algo. O signum é então definido como res usada para significar algo além de si. Portanto, todo signo é também uma coisa, pois se não fosse res, nada seria. Por outro lado, nem toda coisa é signum. Assim, nota-se que desde Santo Agostinho as coisas e os signos se confundem: conquanto diferentes, parecem inseparáveis, às vezes indistinguíveis, visto que a res é por vezes signum e todo signum é também res. Mas, no De doctrina christiana, são eles separados, estudando-se primeiro as coisas, no livro I, e depois os signos, no livro II. ${ }^{529}$

Na poesia lírica seiscentista, contudo, o amor agudo é, ao mesmo tempo, uerba e res. Nesse sentido, tendo em vista que essa poesia é uma produção retórico-poética, mostra-se importante ressaltar que nas retóricas antigas as res são entendidas, às vezes, como os "pensamentos" adequados à matéria do discurso e buscados na inuentio $;{ }^{530}$ ao passo que os uerba revestem e exprimem essas res da invenção na elocutio. ${ }^{531}$ Além disso, outras vezes, a res (no singular) refere-se à própria matéria ou assunto sobre a qual se discorre. ${ }^{532}$ Aquele agudo amor, então, constitui-se na lírica seiscentista como

que, se não fosse alguma coisa, não existiria. Mas, por outro lado, nem toda coisa é ao mesmo tempo sinal" (A doutrina cristã, op.cit., pp.42-43).

${ }^{529}$ O próprio autor explica por que fez tal divisão: "Quoniam de rebus cum scriberem, praemisi commonens ne quis in eis attenderet nisi quod sunt, non etiam si quid aliud praeter se significant; vicissim de signis disserens hoc dico, ne quis in eis attendat quod sunt, sed potius quod signa sunt, id est, quod significant" (De Doctrina Cristiana, II, 1). Na tradução de Nair de Assis Oliveira, o mesmo trecho aparece da seguinte forma: "Ao escrever o livro anterior sobre as coisas (De rebus), procurei previnir que se fizesse atenção, aí, apenas ao que as coisas são em si próprias, prescindindo do que possam significar além de seu sentido próprio (I, 2, 2). Agora, ao tratar sobre os sinais (de signis), advirto que não se dê atenção ao que as coisas são em si, mas unicamente ao que significam, isto é, que elas se manifestam sinais de algo diferente." (A doutrina cristã, op.cit., p.85).

${ }^{530}$ Conforme a explicação de Henrich Lausberg: "A primeira fase da elaboração é a inventio, i.é, o acto de encontrar pensamentos (res) adequados (aptum) à matéria, conforme o interesse do partido representado (utilitas causae), pensamentos que servem como instrumentos intelectuais e afectivos para obter, pela persuasão do juiz, a vitória do partido representado. Esta persuasão, em si mesma, consegue-se pela criação de um grau de credibilidade elevado, mesmo quando a materia em si desfrutava, de antemão, apenas de um grau muito baixo de credibilidade" (Elementos de retórica literária, op.cit., p.91).

531 “A elocutio ( $\lambda \dot{c} \xi ̌ \iota \varsigma, \varphi \rho \alpha ́ \sigma ı \varsigma$; [port. elocução]) é a expressão lingüística (verba) dos pensamentos (res) encontrados pela inventio" (Idem, p.115).

${ }^{532}$ Um bom exemplo desse uso de res é o seguinte trecho da Rhetorica ad Herennium: "Quoniam in hoc libro, Herenni, de elocutione conscripsimus et, quibus in rebus opus fuit exemplis uti, nostris exemplis usi sumus et id fecimus praeter consuetudinem Graecorum, qui de hac re scripserunt, necessario faciendum est, ut paucis rationem nostri consilii demus. Atque hoc necessitudine nos facere, non studio, satis erit 
res e uerba: trata-se de "inventar" por meio de palavras aquilo que seja o amor, deleitando e instruindo os leitores. Na sua difícil elocução retórico-poética é que essa concepção amorosa da aguda poesia do século XVII se faz matéria.

Sendo matéria feita de uma lingua mentitrice, o amor agudo, humano, nunca alcança o original e perfeito amor divino. Aquela imitação perde-se em obscuros labirintos sem ver a luz deste seu modelo; todavia, perde-se para encontrar-se: com esses mesmos labirintos busca deleitar e esclarecer a razão humana, mostrando por espelho, em enigma, o que não se pode ver face a face. Nesse sentido, aconselham versos de D. Francisco de Portugal "que o frágil ser no ser divino aprove, / e, qual águia em cristal, consulte o espelho / e ũa beleza noutra se renove". ${ }^{533} \mathrm{O}$ frágil amor agudo é imperfeito reflexo do divino, sendo que a inapreensível beleza amada renova, constantemente, o desejo que nunca chega ao fim, pois tal amor humano, como o definem versos atribuídos a Antônio Barbosa Bacelar, "é um desejo / De fermosura amada, / É paixão dentro na alma radicada / De lograr o que amo e o que vejo". 534 Enquanto desejo e paixão, não pode ser perfeito um amor que nunca obtém em si ou fora de si o que ama.

Esse agudo amor, de palavras constituído, é, enfim, matéria que, definindo-se, define a lírica amorosa seiscentista como uma aguda imitação de amorosa linguagem divina, uma difícil interpretação do conceito amoroso original: agudeza e dificuldade essas que, racionalmente, tentam revelar algo muito além de qualquer razão.

\footnotetext{
signi, quod in superioribus libris nihil neque ante rem neque praeter rem locuti sumus. Nunc, si pauca, quae res postulat, dixerimus, tibi id, quod reliquum est artis, ita uti instituimus, persoluemus. Sed facilius nostram rationem intelleges, si prius, quid illi dicant, cognoueris (IV, 1)". Na tradução de Ana Paula Celestino Faria e Adriana Seabra, eis como aparece o mesmo trecho: "Já que neste livro, Herênio, escrevemos sobre a elocução e, quando foi preciso usar exemplos, usamos nossos próprios - contra o hábito dos gregos que escreveram sobre o mesmo assunto -, faz-se necessário que apresentemos, em poucas palavras, as razões dessa nossa decisão. Sinal suficiente de que o fizemos por necessidade, não por capricho, é o fato de nada termos dito nos livros anteriores, nem antes, nem depois de tratar a matéria. Agora, assim que dissermos resumidamente o que demanda o assunto, continuaremos o que iniciamos, explicando para ti o restante da arte. Entenderás, contudo, mais facilmente a nossa razão se antes souberes o que dizem os gregos" (Retórica a Herênio, op.cit., p.199). Fica evidente que a res de que se fala é a matéria ou assunto do livro IV da Rhetorica ad Herennium: a lexis dos gregos ou a elocutio dos latinos. A dificuldade declarada pelo autor está em tratar de um assunto (res) que só tinha sido devidamente estudado pelos gregos.

${ }_{533}$ Portugal, D. F. de. Divinos e humanos versos, op.cit., p.290.

${ }^{534}$ Obras poéticas de António Barbosa Bacelar, op.cit., p.423.
} 
ANEXO 


\section{Saudades}

de

\section{Lidia, e Armido}

Expostas na figura de Ella ficar saudosa

e magoada em terra, por Elle se ausentar

embarcando em huma Armada $\&^{\mathrm{a}}$

Compostas

Por Bernardo Vieira Ravasco

Irmão do grde. Pe. Ant. ${ }^{\circ}$ Vieyra

da extincta Companhia de Iesus 


\section{Advertencia}

No tempo em q̃. com as successivas guerras com Castella, por sostentar Portugal a Coroa no seu Legitimo acclamado Rey os̃. D. João $4^{\circ}$, havia por cauza de irem á Campanha, a experimentada, e triste separaçaõ dos filhos de suas Maỹs, dos Espozos, de suas Espozas \& ${ }^{\mathrm{a}}$, moveu a compaixão de algũns Engenhos poeticos desse tempo a pintarem essas lastimozas partidas, com o titulo de $=$ Saudades de Lydia, e Armido , $=$ como alem de outras, foram as $\tilde{\mathrm{q}}$. compôs o $\mathrm{D}^{\mathrm{o}}$. $\mathrm{Ant}^{\mathrm{o}}$. Barboza Bacelar, primeiras, e segundas; hũas q̃. vem impressas no $1^{\circ}$ Tom. das Fenix a pag. 77; outras no $2^{\circ}$ Tom. pg.33; e em competencia dellas, as q̃. compôs outro Engenho, e vem tambem impressas no Tom. $1^{\mathrm{o}}$ da $\mathrm{d}^{\mathrm{a}}$. Fenix pg. 32. E assim, entre a occurrencia destes enthusiasmos, tocou parte ao Autor das presentes que declarado fica no rosto antecedente $\&^{\mathrm{a}}$. 


\section{Saudades}

$\mathbf{s}^{\mathbf{a}}$

=outavas $=$

$1^{\mathrm{a}} \cdot{ }^{\prime \prime}$

Era o tempo gentil, em que as boninas a respirar no berço comessavam, renovando as memorias perigrinas, que á vida de suas cores trasladavam: Emulas fixas de outras mais divinas, seu campo azul mentido equivocavam; Lascivo engano ao Deos, que bruto, a Copa deixou de Ganimedes por Europa.

Quando nas ondas, que ilustrou, surgindo aquelle fatal Grego, aquem recreya, seus marmores lavando, e consumindo em cinzas Troya, em muros Ulyssea: Dos Lenhos, que o valor foi construindo, para serem do Sol nadante estrêa, galhardos, e guerreiros authorisam o Ceo que ofendem, e o cristal que pisam.

Em todos os Mortais se obedecia da doce pressa o imperio imaginado; nem folha o ár, nem onda o mar movia, 
calada a noite, o dia sepultado:

Tudo entre horror, e sombra se escondia,

atado o vento, o sono desatado;

e delle já vencidas as estrellas,

tropessavam no curso menos bellas.

Deu, de hũ bronze ferido o ingrato alento,

o primeiro signal á forte Armada:

Altera o Mar o féro movimento;

perturba a Terra a Leva inopinada:

Tudo abala o confuso sentimento;

a nada acerta a pressa alvorossada:

Ferve o embarcar nas Naos em toda a parte;

em toda geme Amor, padece Marte.

Padece Marte; porque o mais briozo

se sente ao despedir menos valente;

que o termo de apartarse, he taõ penozo,

que o sente fraco quem feroz naõ sente:

Geme Amor; porq̃. o impede maviozo

dos coraçoẽns a fama impaciente;

transformando esta doce tirania

o Amor em morte, a morte em tirania.

Em quanto todos mal se despediam, em quanto ápressa todos se embarcavam, só de Lidia os desprezos se acendiam, só de Armido as memorias se apagavam: 
Em deluvios os olhos convertiam

as razoẽns, que os deluvios igoalavam;

e Lidia o fogo destilando em mágoas;

incendio ás agoas he, naufragio ás frágoas.

$7 "$

Era Lidia, hum dominio perigrino

da vista, da prudencia, da Loucura;

Ser, que fez o Divino mais divino,

á fermozura menos fermozura:

De unidas perfeiçoẽns confuzo atino,

de oppostos Astros conformada usura;

tudo prodigios, e silencio tudo;

hyperbole de sy, milagre mudo.

O que era Lidia, só se interpretava

da gloria com que tudo suspendia;

porque a fé, que entendida a venerava,

era ignorando-a sabia idolatria:

Confundia a vontade o que ignorava,

incredulo o juizo do que via;

que por naõ duvidarse, póde verse,

para inferirse bem, naõ perceberse.

$9 "$

O que della podia só dizerse,

he só que naõ podia compararse;

que intentar de algum modo encarecerse,

era aspirar de todo o modo errarse:

Sempre foi nella igoal perigo o verse 
ao cego precipicio de explicarse;

que foi, para naõ crerse de exaltada,

para naõ comprehenderse imaginada.

$10 "$

Era de Armido empenho transformado,

assim como de Lidia o éra Armido;

taõ unidas as almas nũm cuidado,

como hum só ser aos coraçoẽns unido:

Qualquer, éra nos dous multiplicado,

e taõ confusamente transferido,

que ambos erarm objectos dous precisos;

vistos, Adonis; vendose, Narcisos.

$11 "$

Em este Armido raro, aquela idea

que aos mais bellos Pastores desprezados,

em Jupiter ardendo, e Galatea,

mais discretos fizera seus cuidados:

De Venus vibra, de Vulcano estrêa,

graças, e rayos, com tal arte atados;

que quem as (sic) via desatar sem arte,

via a espada em Cupido, a aljava em Marte.

$12 "$

Daquelles dous extremos, que parece

negam ser entendido, e venturozo,

composto excesso foy, que desvanece

o impossivel das ditas mais penozo:

A competencias nelle resplendece

quanto a invejas despreza generozo; 
novo assumpto do Fado, e Natureza,

Mimo da Graça, Genio da Grandeza.

$13 "$

Nas batalhas de Amor, tinha mostrado

de seu furor a branda valentia:

Nas de Mavorte agora ensanguentado, provar da espada os fios pertendia:

Já seu valor, á fama consagrado,

do peito arranca a seta, que o feria;

e resolve com sigo, em breves sumas,

novos Astros ir ver, novas espumas.

$14 \prime$

Mas quando se resolve, entaõ duvida

lutar rendido com poder mais forte:

Se a Lidia vê, suspende infausto a ida;

se a retrocede, ofende indigno a Sorte:

Vella, e ficar, seria infame vida;

Naõ a ver, e partir, ingrata morte:

Mas nesta nobre, ou vil perplexidade, cede as Leis do valor ás da vontade.

$15 \prime$

Estava Lidia em brassos de hũ desmayo,

mortal sagrado da culpada vida;

que foi delicto, naõ perdella ao rayo

da dor, que a morte faz menos temida:

Fez nella a vida seu funesto ensayo,

para quando de sy fosse homicida;

e unindo parocismo a parocismo, 
remedio á pena foy seu mesmo abismo.

16

Já sem calor o fogo se escondia

entre as cinzas da neve que o deteve;

se as cinzas desmentiam que inda ardia;

que já espirava, confirmava a neve:

Sendo toda de fogo, estava fria;

sendo de neve, toda ardendo esteve:

thé que Armido aplicando á vista o rôgo, a neve anima, ressucita o fogo.

$17 "$

Qual de pálidas sombras afrontada,

primogenita Luz, quasi indistinta,

da branca maõ da Aurora desatada,

Fenix renasce de sy mesmo extinta:

E em pérolas a vida destilada,

nas flores onde as vê, bebe sucinta;

thé que animado o Sol, troca os horrores

das urnas de cristal, em resplendores.

18

Assim Lidia: Mas quando a dor adverte

na adora (sic) occasiaõ de seu tormento,

a queixa esforsa, e timida converte

a esfera de ágoa, em vóz de sentimento:

Nada intenta dizer; que triste a Sorte,

sossóbra a dor o mesmo pensamento;

e náufrago o juizo em tantas mágoas,

se salva em ondas, e se afoga em frágoas. 
$19 \prime$

Do mesmo modo Armido, o fogo, e agoa

une cobarde, e augmenta enternecido;

no peito, e olhos condensada a mágoa;

na boca, e vóz, o medo convencido:

Perplexo admira em Lidia nova frágoa, de outra belleza extremo nunca ouvido;

pois vio nascer dous soes, chorar Faetontes,

luzir ecclipses, despenharse fontes.

Ambos se veêm, se elevam, se retractam

no cristal, de que os olhos são quartinas;

e em cada especie, mil memorias tractam,

que o mesmo Amor da lingoa fez indignas:

Oh como docemente ambos rellatam

as venturas, que o fado fez mofinas;

e que impossivel he dizer a pena

o q̃. hum do outro infere, o q̃. o condena!

Encontrados na vista os pensamentos, gela hũ frio temor os tristes peitos:

Ambos se calam; e ambos seus tormentos, mudamente encarecem nos effeitos:

Interpreta-os a dor nos desalentos, equivoca-os a mágoa nos conceitos:

Mil segredos decifram, mil pesares

mal os dous coraçoẽns, em quanto mares. 
Como de ambos unidos, se compunha aquella vida, que a ambos animava; entre os olhos a morte se dispunha, que mais tiranamente os apartava: Mas a causa, que nelles se propunha, de tal modo a sentila os transformava; que duplicando as almas, e os gemidos, duas Lidias a chóram, dous Armidos.

$\mathrm{Na}$ triste suspensaõ deste accidente, (mais triste no privar de cada instante) que suspiro naõ he mais eloquente? que palavra naõ he mais ignorante? Sem fallar, se prometem sabiamente nos derradeiros ays, fé mais constante; que nunca teve Amor mais finos lassos, que dividindo os ultimos abrassos.

Mas como sempre a dor de quem se ausenta, he menor, que o tormento de quem fica; na mesma dor, Armido á dor se alenta; e Lidia o seu tormento multiplica: Por isso já cruel se não contenta só coa morte, a que a vida sacrifica: ás queixas se remete de mil sortes, por ter em cada queixa muitas mortes. 
$25 "$

Querido meu (lhe diz) querido Ingrato:

que tirania he esta, que emfim usas;

merece meu amor, meu ser o trato

com que teu ser, e meu amor acusas?

De nossos coraçoẽns eram retrato

as finezas em nós sempre confusas:

e agora, que as distinguem tais effeitos,

em mim saõ culpas, o q̃. em ty defeitos?

26

Que pertendes ir ver nessas estrellas?

que desejas pisar mais bellas flores?

já as flores naõ aprendem a ser bellas,

nem estrellas a ter mais resplendores:

que nas flores, mudavas as cautellas;

nas estrellas, fingias os favores:

Oh vil lisonja! Tu te perverteste:

Eu me enganava então: naõ eras este?

$27 "$

Se me dizes, Armido, que he preciso

romper os lassos, que inda Amor tecia;

nessa acçaõ vituperas teu juizo,

desacreditas tua fidalguia:

Quem despreza o que adora, naõ tem ciso:

quem se esquece do que ama, se injuria;

e se illustre, ou discreto me adoraste,

neste delirio a ty te profanaste. 
Lembrate Armido, Armido, aquelle empenho com que em nascendo, logo nos quisemos?

Destas almas repara no despenho, violadas quantas leis ambos lhe demos:

Vê que fé tem; que fim; que desempenho os vottos, que mil vezes nos fizemos; e se naõ queres respeito a nada, considerame a mim de ty deixada.

Mal cuidey, que este tempo de delicias o viesse agora a ser destas batalhas! nem que o Amor, que peleja entre caricias, convertesse os despojos em mortalhas! Mas pague a vida á morte estas premicias, que em matarme só quero que me valhas; e se naõ matas quem ao campo chamas, teu brio ecclipsas, teu valor infamas.

Se aspiras ser da Fama hum dos ousados, Pallas, e Thetis a teus pés rendidas; naõ busques Mares nunca navegados; naõ busques guerras nunca acometidas: Aqui pélagos tens nunca buscados; aqui batalhas tens nunca vencidas: Deixa essa gloria de outro mar, e terra; pois nesta terra, e mar deixas a guerra. 
Dá fim primeiro áquella q̃. he mais fera; tira esta vida, que te ofende triste; pois nunca vil a espada degenera que mata vencedora aquem resiste: Toda a campanha azul, he estreita esfera á gloria, que em matarme só consiste: Carrossa o tex baxel será triunfante, se morta em teu triunfo eu for diante.

Oh não sigas, Armido, essa jornada em que essa vida vai taõ duvidosa! Ou me tira esta tua mallograda, que quando Deos queria era ditosa: Não me leves lá essa afeminada, que cá te fica a tua valerosa; olha $\tilde{\mathrm{q}}$. he tua, e corre o mesmo perigo no mesmo extremo com ̃̃. a minha sigo.

$33 "$

Mas ay (vida) que a tua em mim não fica, e só fica o tormento de deixarme! Não choro a vida, pois se sacrifica; sinto o tormento, pois naõ quer matarme: Ambas me levas; bem se qualifica o excesso com que vás tiranizarme; pois disposestes de tal modo a queixa, que huã se vai, outra me deixa. 
Vai a minha, discreta por seguirte;

deixame a tua, ingrata por deixarme:

Ambas se uniram nalma, que a servirte

vai da gloria que tens de atormentarme:

Em seu lugar terey, para sentirte,

meus sentidos, que bastam a acreditarme;

porq̃. he na ausencia, sempre o mór tormt ${ }^{\circ}$,

padecer sem dizerse o sentimento.

$35 \prime$

Se darme vida cuidas que he clemencia,

nella introduzes nova tirania;

pois se a vida me levas nesta ausencia,

deixarme viva, he morte que eu temia:

Para ausentarte, tudo foi violencia;

para matarme, tudo cobardia:

Quem vio nunca suplicio desta sorte;

tirarme a vida, e naõ me dar a morte?

36

Aos golpes da agoa, os marmores se rendem;

ao beneficio, as feras obedecem:

A ty, estas fontes muito mais te incendem;

e com tigo, as finezas desmerecem:

Menos dureza os marmores pertendem;

menos fereza os brutos apetecem:

$\mathrm{Tu}$, no insensivel, e cruel, esperas

os marmores vencer, vencer as feras. 
Armido, meu senhor, querida Prenda; como de mim, cruel, te naõ lastimas? Mateme já; e acaba: naõ se entenda, que nem me matas, porq̃. naõ me estimas: Se queres, que a viver morrendo aprenda, comésse a vida; o coraçaõ que animas aqui tens a teus pés, Armido indigno; ouveme fero, matame benigno.

Qual a flor, que nocturna maravilha em fragancia de neve se desata, e desprezando a cándida mantilha, purpuras pisa em trono de escarlata: Mas por deixala o Sol, a pompa humilha; da magestade, fórma tumba ingrata; e agonizando a vida vespertina, caduca exala, e murcha se reclina.

Assim Lidia (que as mágoas suspendia, porque os solussos, e os suspiros éram tropêsso á vóz enferma, que os dizia clausula ao coracaõ deque nascêram: Se humilha, com queixosa cortesia, áquelles pés, que tanto a obedeceram: Prostrase Armido, que na dor a igoala; e assim prostrado, deste modo fala. 
$40 "$

Vida minha adorada: bem confesso,

que tudo quanto dizes, me convence;

porem se o nosso amor, he todo excesso,

obralos, naõ sentilos nos pertence:

Este em que estamos, ûltimo congresso,

de nossos coraçoẽns; se a ty te vence;

a mim me anima, quando arrependido

podéra a vida ter antes perdido.

Mas permiteme, oh doce gloria minha, (que tu sempre o has de ser nas móres penas)

que me desculpem quantas razoẽns tinha

para esta acçaõ, que tanto me condenas:

E logo julgarás se te convinha

naõ partir eu, partindo essas enténas:

Valhame o teu juizo; e dê licensa

á minha immensa dôr, tua dôr immensa.

$42 "$

Se a fortuna abrassey de novo Marte, foy só para de novo merecerte;

porque a excelencia de saber amarte,

fez, para mais te amar, deixar de verte:

a fé desta fineza de adorarte,

he $o$ ardil que inda tinha de quererte:

Vê logo, se este amor taõ perigrino,

póde ser justamente desatino. 
Amar sem padecer, he grande dita;

mas dita, que não dá merecimento;

que a pureza do amor, mais se acredita

na ausencia, na firmeza, e no tormento:

Aquelle, que ser raro solicita,

sempre dá que lograr ao sofrimento;

e se ditosos nunca padecemos,

não dirás oque a nós nos merecemos?

44

Se inda não lamentamos saudades,

nem mágoas de memorias descontentes;

se unidos sempre em nossas liberdades,

nunca nos vimos athé agora ausentes:

Se éramos ambos cegas divindades;

de nós mesmos idolatras contentes:

Como podia, em tal contentamento,

lograrse a gloria de nenhum tormento?

Permite logo, oh Lidia, que esta ausencia nas mesmas penas nos duplique o gosto;

que sempre o bem, do mal foy consequencia;

e da gloria, o tormento pressuposto:

Do vento, e mar entregue á contingencia,

firmezas só fabrico, a tudo exposto:

Não cuides q̃. me aparto, se me ausento;

q. a unirme mais, me leva o mar, e o vento. 
46

Com tigo fico, e vou tambem comigo

neste êrro inevitavel de apartarme:

Vê que modo taõ nunca usado sigo,

por naõ deixarte a ty, por naõ deixarme?

Levarme a mim, e não ficar com tigo,

éra mais impossivel que ficarme:

julgo logo, se he mais ir quando fico;

pois, por naõ me apartar, me multiplico?

$47 "$

Tirana sutileza he esta ausencia,

que vá comigo, que com tigo assista;

pois dobro a pena, e nego a resistencia

ao novo effeito que esta dor alista:

Que a saudade ao partir doce excelencia,

ao ficar substituê ausente a vista;

e eu dando injusto alento á crueldade,

fico sem vista, parto sem saudade.

$48 "$

Porque me fico, parto sem saudade;

porque me parto, he certo que naõ vejo;

e aquella he mais cruel penalidade

onde a presensa he véo do seu desejo:

Ser alivio levala, he falsidade,

pois nesse alivio, nova dor elejo;

que levar a saudade na presensa,

he das dores a dôr que he mais intensa. 
Mas se dizes, oh Lidia, ser esta alma

a tua, viveremos docemente;

pois pediremos, em tão triste calma,

socorro á causa della mais presente:

eu co-a tua soberba levo a palma:

tu co-a minha naõ ficas differente:

Naõ sintas logo ir eu, nem despedirme,

pois tu comigo vás, e eu fico firme.

E quando éstas razoẽns te naõ abalem, respeita aos rayos de huã illustre fama, de que as estrellas por luzir se valem, de que o sol por viver esconde a chama: Naõ permitas, que só de mim se calem os eccos do Clarim, que aos mais aclama; nem a ambiçaõ prefiras de lograrme, aos créditos de mais authorizarme.

Que quando vires, que galhardo chego a teus brassos... Mas nisto hũ graõ bramido do tremendo metal, rompe o socêgo, e o medonho signal dá repetido:

Ficase Armido perturbado, e cego;

Lidia sem vóz, sem vida, e sem sentido:

Armido, quasi hum extasi de pena:

Lidia, quasi hum cadaver de assucena. 
Ficate Lydia embora, que he chegado (lhe diz Armido) o tempo q̃. he preciso deixar de verte, e obedecer ao fado, contra as leis do desejo, e do juizo: A vida aceita neste naõ logrado abrasso, em que te dá seguro aviso hum coraçaõ, que se viver aspira, he porque tenha o mal aonde mais fira.

Armido, emfim, se parte morto, e triste; e Lidia, emfim, se fica outra vez morta: Nem Lidia ás ancias da sua dôr resiste; nem os lassos Armido á pena corta: A dor que he grande, athé no alivio assiste; nenhum remedio á sua mágoa importa; porque excede obstinada nas porfias destas duas discretas tiranias.

Quem nasce triste, e vive sem ventura, sente pouco acabar o seu queixume; que hum padecido mal se se aventura, deminue o tormento no cosrume: Mas quem, sem prevenir mágoa futura, o arrojo a mayor dita do seu cûme, de dous extremos ûne impaciente a dôr no bem que perde, e mal q̃. sente. 
55

Por isso Lidia sente mais que Armido; e a dor nelle he menor por meditada: Mas ay, que Armidoa tinha presumido, e só agora a padece experimentada! Sem vida chega á praya; e sem sentido o ser de Lidia, em vaõ delle deixada: para ambos foi, naquella sorte escura, tumba o batel, o estrado sepultura.

Já as mal acesas luzes apagava nas sallas de zafiro aonde ardiam, a roixa Precursora, que acordava ao rey das flores, que de o ver se riam: De pavêas, e flamulas se ornava a Armada, cujas Naós Hybla venciam, rompendo alegre a bélica armonia da naval arvorada o fatal dia.

Do monte desce já, que naõ receya, a carrossa do Sol os resplendores; e o zefiro suave, que os recreya, respirava lascivo em seus ardores: Quando as áncoras leva, a vela estreya cos costumados náuticos rumores, a capitánia; e entre nuvêns alvas, de luzidos trovoẽns fulmina salvas. 
58

Da terra, e mar, horrendas, e galhardas, as Naos, e Fortalezas se respondem; articulam lhe as vozes as bombardas, os assenos o fumo em que se escondem: Teme o Tonante as armas, que bastardas, indignamente ás suas correspondem: tudo entre assombros tréme agonizando, gemendo o ár, os éccos retumbando.

Desperta do accidente, ao som dos tiros, a triste Lidia, para ser mais forte que a morte de suas áncias, e suspiros, ver partir quem lhe nega a mesma morte: Rompe com ays os liquidos zafiros; culpa com vozes sua ingrata sorte; e no estrago dos ultimos ardores, passa a dôr a borrasca de furores.

$60 "$

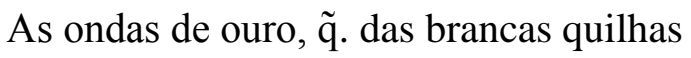
a cristalino impulso maltractadas, éram do vento vácuas maravilhas, éram do Sol injurias veneradas; se vêm qual golfo soltar as quadrilhas, de descorteses mótos profanadas; e rasgada da insarcia as assucenas, feridas prayas, naufragas entênas. 
Foy carpando, e surgindo toda a Armada

da Capitánia o rumo, e cortesias;

pouco a pouco se vai vendo afastada, e ouvindo mal das Tubas as porfias:

Já Bellem pássa, e deixa a doce estrada, que ennobrecem do Tejo as ondas frias; e as Campanhas sulcando do occeano, todas as Naos largavam todo o pano.

Se he natural a todos certa mágoa com q̃. se apartam quando se despedem, qual serîa dos dous a triste frágoa por motivos q̃. em vão sua dôr excedem? Elle nũm bordo, Ella junto da agoa, já pouco alivio ás Naos, e a terra pedem; pois as Naos no orizonte se escondêram, e a terra, emfim, nas sombras q̃. descêram.

63"

Estava a noite triste, e só se ouviam na solitaria praya, e na espessura, queixar as ondas, e Aves, que anunciam com funesto gemido, a dôr futura: os éccos, o silencio, o horrôr, faziam mayor o espanto, a sombra mais escura, confundindo o pavor, em varios medos, ondas, prayas, gemidos, e arvoredos. 
$64 ”$

Tudo Lidia despresa generosa,

e a praya com discreto desatino

desiguálaõ os cristais de neve, e rosa,

que hũ só ponto igoalava perigrino:

Quanto os profana espuma ambiciosa,

de Venus se presume outro destino;

e saõ tudo o que estampam prantas bellas,

na praya flores, e na espuma estrellas.

65

Sóbe se Lidia entaõ, cega, a hũ rochedo,

que no mar debrussado, em sy se tinha;

e êntre as consultas de valor, e mêdo,

resolve que matarse, só convinha:

Parece á causa tarde, á vida sêdo

em quanto infaustamente se detinha;

mas naõ quis dar ao mar a triste vida,

sem dar ao vento a extrema despedida.

66

Vaite emfim (diz) Armido; e emfim deixaste

féro a Lidia, aquem tanto mereceste?

Dize: aque fim (cruel) tanto me amaste,

se em nosso amor se havia de ver este?

Se nessa acçaõ como valente obraste,

como amante as da fé nella perdeste?

Oh naõ sei se terás lá tanta fama,

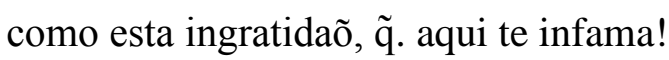


$67 "$

Discorre contra sỹ quem nesciamente despreza a posseçaõ pella esperansa: Só tu deixas a gloria permanente, por querer infeliz esta mudansa! A esperansa foy sempre contingente; e só no logro do seu Bem descansa: julga logo, se deixas entendido pello bem da esperansa, hũ possuîdo.

$68 "$

Sem saber onde vás, te vás tirano?

e sabendo o que perdes, tudo deixas?

Quando choráres triste o teu engano, entaõ te lembrarás de minhas queixas:

As fortunas, que saõ vil desengano, ao mór engano andávam sempre anexas; mas se o mais ignorante, he mais ditoso, ignorando onde vás, vás venturoso.

$69 "$

Se por mais padecer he $\tilde{q}$. te ausentas, e nessa industria fias as finezas, mayor fineza fôra, que a que intentas, sentir o naõ sentir perder a empresa: E se tu dessa pena te contentas, fôras cá triste de naõ ter tristeza, que o padecer no padecer tormento, he da fineza o mór merecimento. 
Se a vago lenho, entregue ao mar, e vento

(todo inconstancias hũ, outro mudansas) naõ querendo de mim fiar o intento, fias a vida, o ser, e as esperansas:

A quantos fez hum instavel pensamento ser principio de suas confiansas?

Prossegue logo tuas incertezas, que eu mostrarei quaes saõ minhas firmezas.

$\mathrm{Qd}^{\mathrm{o}}$. ésta noite a extrema vóz me viste, que inexoraveis foram teus sentidos; pois te naõ magoávam, se os ouviste, de minha dôr os miseros gemidos: A teu juizo, e olhos resististe, da tiranîa em lastimas movidos: he taõ ferina a tua crueldade, q. nem com tigo tens humanidade.

Mas se o teu coraçaõ he de ásso fino, que nelle naõ mostraste outra fineza, que vale desta agoa, e fogo o desatino, se a fogo, e agoa usurpas mais dureza? Porem, se o ferro mais diamantino, perde no fogo só sua firmeza; cada suspiro meu, he hũ rayo insano; mais os podes temer, que os de Vulcano. 
$73 "$

Se com tudo, desprezas duro a frágoa que contra ty fulminaõ meus suspiros, os máres teme de huã nova mágoa; que te sossobrem com vorazes giros Mas ay, q̃. levas todo o vento, e agoa a teu favor, e os vencem teus retiros! em vaõ procuro obrar, em agoa, e fogo, acçoẽns, q̃. o vento, e agoa apagam logo.

$74 \prime$

Segue logo ditoso essa agoa, e vento, que a este meu preferiste fogo, e agoa; que se nessa agoa tẽns contentamento, só me contenta a mim ter ésta frágoa: Levete embora o mar o salvamento, e eu fique embora entregue á minha magoa; que ambos teremos n'agoa, e fogo a sorte; tu na agoa a vida; e eu no fogo a morte.

$75 "$

Mas vós pesadas Aves, que nadantes apartais éstas almas sempre unidas, se da agoa, e vento vir quereis triunfantes, naõ sejais de vós mesmas homicidas: Virais logo éssas ásas espumantes, se naõ vereis, já tarde arrependidas, infamemente em cinzas abrasados mantos, entenas, quilhas, e costados. 
Pois faraõ rosto ao ar, em meus gemidos, impaciente o fogo em minhas mágoas, os deluvios em nuvẽns convertidos, os suspiros em vento, os ays em fragoas:

Do seu rodas os Astros sacodidos; bramir os ventos, resultar as agoas; e ser ao nauta deste meu pressagio lastimoso signal vosso pressagio.

Mas ay (cruel!) q̃. o fogo, o mar, e o vento, cada qual teu desejo solicita! Todos conspiram para o meu tormento; mas meu tormento em todos se acredita: Se huã só pena dá merecimento, quanto terá quem tem pena infinita? Vós o dizeis desprezos de meu rôgo, padecidos no vento, n'agoa, e fogo.

Se ésta naõ fôra a dor mais inaudita, mais podéra queixarme d'agoa, e vento; mas tua crueldade facilita multiplicarse em tudo o meu tormento: E se a fineza nelle se habellita, nelle se entende o meu merecimento; mas vem logo a advertir a minha magoa do que eu pósso sentir o vento, e a agoa. 
$\mathrm{O}$ vento, he ar, que nunca tem constancia;

o mar, agoa que nunca tem firmeza;

o fogo, luz q̃. abrasa na inconstancia:

tu, de todos, em summa, és natureza:

De ser mais claro q̃. a agoa, tens jactancia, sendo em cada Elemento varia a empresa; mas tudo infames, sendo o vil intento menos firme q̃. o fogo, o mar, e o vento.

$80 "$

Se de teu odio o fogo se retira;

se o vento dos affectos se afogenta;

se teu valor por outro mar suspira;

ou tudo, e por meu mal, de mim te ausenta:

A meu amor he tudo vãn mentira,

porque em seguirte, nada me atormenta:

Naõ fujas logo; párate a meu rogo,

que naõ te vale o vento, o mar, e o fogo.

$81 "$

Em mim o exemplo vê infaustamente, no fogo Venus sou, Thetis nas ágoas;

que esse nome me daõ (bem q̃. indecente)

dos meus olhos o mar, do peito as frágoas:

E na morte de dor taõ delinquente,

nem os olhos valem á dor, nem o peito ás mágoas;

pois me naõ serve já de desafogo,

nem arder na agoa, nem chorar no fogo. 
Mas se arder, e chorar naõ vale aos tristes, que póde mais, se he grande, huma tristeza; como na minha vivo, se presistes, e o coraçaõ de Armido te despreza? Na dôr á pena de tua dor resistes, convertendo a em tua mesma natureza; e como vives já desse talento, no meu chorar, e arder, tens novo augmt ${ }^{\circ}$.

$83 "$

Nilos os olhos, e Vesûvio o peito me viste, fero Ingrato, e te ausentaste; nem a incendios tiveste algum respeito; nem aos deluvios termo algum goardaste: E se o meu coraçaõ vendo desfeito em fogo, e agoa; o teu nunca abrasaste; que lagrimas, já podem, que suspiros reduzirte (cruel) de teus retiros?

Quantas vezes queria naõ quererte, só por poder assim mais adorarte? Agora, só suspiro poder verte, e naõ vale a meus olhos suspirarte: Oh quem cuidára, Triste, que a perderte chegára nunca o extremo de ausentarte! Mas se he teu gosto amar o mar, e o vento, quero querer por gosto esse tormento. 
$85 "$

Se por tỹ choro, se por tỹ suspiro,

nem assim modefico o meu tormento;

que como padecer somente aspiro,

no mesmo alivio dóbro o sentimento:

E se no fogo de meus ays respiro,

e na agoa de meus olhos tomo alento;

he por ter contra mim nos meus sentidos,

o fogo, e a agoa a teu favor unidos.

$86 "$

Nem dos ventos receyas as tormentas?

Nem témes da agoa os casos perigosos?

E témes humas lagrimas isentas?

Receyas hũns suspiros amorosos?

Naõ fujas naõ, que as lagrimas augmentas,

e os suspiros duplicas mais queixosos:

essa tormenta teme no caminho,

suspende ao mar o lenho, ao vento o linho.

$87 "$

Porque, Ingrato, naõ ouves tanto rôgo?

porque, Cruel, naõ sentes tanta mágoa?

A mágoa naõ sentida, he toda fogo:

o rôgo nunca ouvido, he todo frágoa:

Nem $\mathrm{p}^{\mathrm{a}}$. a frágoa o ár dá desafogo:

nem para o fogo o mar póde dar agoa;

que naõ acha tal fogo a meu tormento,

agoa nos máres, nem nos áres vento. 
88

Sente o meu mal o ar dos ays ferido,

o fogo dos suspiros magoado,

destas áncias o vento combatido,

destes máres o mal multiplicado:

Só tu naõ sentes, porq̃. sem sentido

a tudo levas esse peyto armado;

mais insensivel éra o meu tormento

do que ar, e fogo, do que mar, e vento.

$89 "$

Quanta gloria deixaste por buscáres

salgados golfos, naõ sabidos climas?

quem te soube mover a desprezares

por esse mar, os dous que desestimas?

Neste naõ tinhas que temer pesares:

nesse pódes perder tudo o que estimas:

Por pisares de Thetis as espumas,

de venus engeitaste, Ingrato, as plumas.

$90 "$

Olha que Venus póde maltratarte;

e que Thetis naõ póde defenderte:

Oh se o seu fogo fôra já abrasarte,

a ver se todo o mar hia a valerte!

Mas se em lugar de ella castigarte,

chegára compassiva a enternecerte,

essa penha de neve fôra frágoa,

e assi fogo advocára o vento, e agoa. 
Mas ay, que para tudo ter perdido, athé Venus se poẽm da tua parte! Se estás dormindo, entendem q̃. és Cupido: Se acordado, que vendo esta o seu Marte: E se tanto te tráz no seu sentido, como póde acodirme, e maltratarte? De Venus, contra tỹ nada presumas, que vás seguro, Armido, contra espumas.

$92 "$

Se te leva por outro pensamento a esperansa dos thalamos da Aurora, oh quantas esperansas leva o vento! oh quantos pensamentos o mar chora! No vento, e agoa levas pensamento, quando a esperansa só no engano móra: Olha naõ aches falsa essa ventura, no vento a morte, na agoa a sepultura.

Com tîgo o vento, e a agoa competindo, ligeirezas o vento, o mar bonansas, o vento excedes no que vás fogindo, o mar excedes no que naõ descansas: O mar, as prayas sempre está ferindo: O vento, ás ondas desfazendo as transas; mas medidos com tigo saõ firmezas, que de ambos vence a tua as naturezas. 
Dizeime máres, e dizeime ventos;

porque, se contra mim sois taõ constantes, o vosso curso igoala os meus tormentos, a minha morte naõ vossos instantes?

Já que as almas levais, e os pensamentos, que em vaõ devidem vellas inconstantes; para que naõ parais por compassivos? naõ seguisteis tambem Ninfas, lascivos?

$95 "$

Respondeme tu já que me pareces menos féro que o vento que me ofende, se deste fogo meu te compadeces, porque esse teu poder me naõ defende? Bem parece, que incendios naõ padeces; e o meu, nesse (sic) agoa, e vento, mais se acende: Mas que remedio pesso ao mar, e á vida, se só na morte a busco apetecida?

96

Sepultame em teus marmores de prata dando vangloria á gloria já perdida; e no epitafio trémulo, retrata da minha morte a causa, e fim da vida:

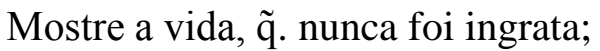
mostre a morte, $\tilde{\mathrm{q}}$. nunca foi querida; e que quem áma o mal, q̃. triste chora, quanto em vida adorou, na morte adora. 
Mas naõ me dês sepulcro; deixame antes levar do vento, e ondas indecentes; que se huã vida anima a dous Amantes, nũm sepulcro naõ cabem dous Ausentes: Em tỹ seremos amvos navegantes; e ambos teremos, com diversa sorte, Elle no vento vida, Eu no mar morte.

$98 "$

Oh quem falou já mais com vento, e agoa, que naõ sentisse em sỹ seu desengano? O vento passa surdo (oh triste mágoa!) a agoa o segue muda (oh triste engano!) Enfurecido o vento, acende a frágoa; emmudecida a agoa, augmenta o dano; que por serem alivio a meu tormento, deixou de falar a agoa, e ouvir o vento.

Mas se acaso me ouvir agoas, e ventos, e disso murmuraes; quando chegares aquelle humano Deos, cujos intentos naõ poderaõ apalacar os meus altares: Dizeillhe; que eu adoro os meus tormt ${ }^{\mathrm{os}_{\mathrm{s}}}$. como reliquias só de seus pesares;

e lá me assiste, ou fero, ou já prospicio, este meu derradeiro sacrificio. 
$100 "$

E pois páram em vento os meus altares,

e neste sacrificio os seus enganos,

no vento se eternizem meus pesares,

no mar seus termos sempre desumanos.

E tu, Mortal, que o Templo profanares

do vento, e mar, a ver meus desenganos;

sabe q̃. em ar, e mar se convertêram

as tristes cinzas, q̃. em seu fogo ardêram.

Mas já, oh Armido meu, te naõ condeno,

que eu tive a culpa toda deste engano;

fôra o meu damno o teu desejo ameno;

o meu querer, teu gosto nesse dano;

e logo fôra gloria quanto peno,

felicidade o mesmo desengano;

pois discreto teria o meu tormento,

no teu arbitrio o seu merecimento.

Bem justamente, logo arrependida

sinto a dor, que só sinto de naõ darte

nos ultimos abrassos, ésta vida,

que naõ teve mais ser, do que adorarte:

E se o desmayo de que fui rendida,

fez, que sem verte, fosses embarcarte;

fará agora o valor, que amante acerte

embarcarme em mim mesma, por îr vêrte. 
Mas q̃. digo! Aquem fasso estes queixumes, exequias com que a morte solemnizo? Vós me ouvîr quantos sois eternos lumes, que exemplo fostes comq̃. me authorizo: Se de mim naõ tivereis lá ciúmes, ser como vós, anela o meu juizo; que se no mar se observam as estrellas, vejame Armido sentilar êntre ellas.

Taõ parecidas sois muitas com elle, como ésta rocha, q̃. ama o seu perigo: comigo está no firme; voz com aquelle que errante chóro, que inconstante sigo: A vós vos tóca convertervos nelle, e ao Ceo fazer felice o meu castigo; pois por menos discretos desatinos, muitos Amantes sey que estaõ divinos.

E tu sagrado Mar, a que ésta vida fio só, por seguir taõ incerto norte, mostrarte só, que a perco agradecida de teu favor, pertende a minha sorte: Mas se lá, doce Armido, for sabida ésta fé, que acredita a minha morte; vê, que quando me dá tua dureza, fasso offendida, ésta ûltima fineza. 
$106 "$

Mal disse Lidia isto, logo á fita, da mais prolixa roupa desatada, do rochedo no mar se precipita; fica na espuma Venus desprezada:

Sulcar valente as ondas facilita, para onde esconderse vîra a Armada; move o cristal, e os remos de alabastro, e a cada movimento acende hum Astro.

Corre velóz o Bergantim de neve, porque a carga q̃. leva, he toda frágoa: Para a ver triumfar o vento, esteve o Deos do Fogo, pello Imperio de Agoa: Muita campanha, se em momento breve, ára o volante da animada em agoa; e animadas as ondas, arde logo a esfera da agoa a exalaçoẽns de fogo.

Mas quem vîo durar $\mathrm{mt}^{\mathrm{o}}$. (oh termo breve!) do fogo unido a neve (oh dor sem rogo!) perde o fogo na neve o ser que teve; perde a neve no fogo o seu ser logo: Vai deixando de ser a neve neve; vai deixando de ser o fogo fogo; e a perdidos alentos, se desata o fogo, e neve em lastimas de prata. 
$109 "$

Do mar, e vento, he já despojo triste

do Mundo todo a mais soberba gloria;

já de jasmins cadaver vago existe,

da vida, e morte a mais gentil vangloria!

Do ser original emfim desiste

aquella Cifra da mais alta historia;

e torpe a fama, cega a sutileza,

seus pinseis, e clarins rompe á Beleza.

$110 "$

Choroute o Sol, por ser sua grandeza

escassa imitassaõ de teus cabellos;

dos Astros a confusa gentileza;

elle sem graça, e elles menos bellos:

Entristeceusse a mesma natureza,

da formosura rottos os modellos:

Lamanetávam as Fontes, Aves, Flores,

o Deos sem vista, a Deosa dos amores.

$111^{\prime \prime}$

Esta, mais empenhada, e mais sentida,

quis que Lidia ficasse eternizada;

a Jupiter propoẽm, serlhe devida

de Estrella fixa a gloria sublimada:

Pois no que obráva, estava preferida

êntre as Deosas deque éra venerada:

O Tonante o concede; e n'um momento, do profundo a traslada ao Firmamento. 
Extremos de juiso, e formosura, sempre foram letal veneno á vida; contra o seu ser, o só portento dura, que a fortuna he das partes homicida: O excesso mais discreto da Loucura, he de Amor a finesa mais valida: sendo pois Lidia taõ discreta, e bella, Estrella póde ser, naõ pôde têlla.

As aquáticas Nimfas, que em choreas, de Amfiaõ triste as delicias celebráram; vencendo ao sôm das conchas as sereas, suspendiam Delfins, Tristoẽns atáram: Quando sem vida admîram entre as areas a Beleza, que os máres profonáram; atónitas da indigna novidade, a presumiaõ infausta Divindade.

Ficáram mudos logo os Instrumentos; as doces consonancias, em gemidos; as delicias das Nimfas, em tormentos; os Tristoẽns, e Delfins, entristecidos: E todos, com discretos sentimentos, os coraçoẽns em fontes convertidos, a conduzem corteses nos seus brassos, do immenso Deos do Mar aos regios Passos. 
$115 "$

Mas Neptuno, que o caso bem sabîa,

lhe tinha prevenido já piedoso,

hum soberbo sepulcro, que se erguîa

sobre cem bases de diamante undoso:

Exala o ambar, luz a pedraria;

e alî sagradamente magestoso,

logra o cadaver tantos resplandores,

que oque sentila estrella saõ menores.

$116 "$

Neste tempo a tirana Imitadora

do Planeta mayor, tinha cortado

a escura méta, adonde Precursora,

do novo dia extingue o já passado:

Sustituta, se naõ fixa da Aurora,

todo o Imperio do Sol quasi usurpado,

éra nos rayos do candor que ardia,

brilhante carro nocturno dia.

117 "

Sereno o mar, o vento socegado,

sem neve o ár, sem sono o que vigîa,

tranquila a noite, o ceo todo estrelado,

só do Farol de Cinthia a luz se vîa:

A Armada naõ veloz, seu curso amado

pisando instavel prata, igoal seguîa;

hũns dormindo sem pena, outros cantando

a mágoa com que a Patria vaõ deixando. 
118

Só triste Armido, posto no bombordo que da parte da terra lhe ficava, quanto mais delle o mais seguro bordo para os cerúleos campos se apartava; mais extendia, com queixoso acordo, as saudades da Prenda que deixava; dando êntre as ancias de chamar por ella, mais agoa ao fogo, mais alento á véla.

Oh triste fado! (diz) onde me levas?

Oh triste engano meu! onde me trazes?

Se ao desengano; porque o naõ relevas?

Se ás esperansas; porque mas desfazes?

Já naõ és engano, pois me naõ elevas;

e se éras fado, bem te contrafazes:

Ambos fingisteis meu contentamento, para em vós dividireis meu tormento.

Vivî alegre no engano do meu fado; mal contente na vida deste engano: Foy o fado na gloria, desemfado; mas o engano na pena, desengano: Que brevémente tudo vî trocado! Vivî felice, já paresso insano; que he crédito naõ ter juizo em sorte, que a vida fez engano, e fado a morte. 
Aquelle alivio d'alma em que vivîa;

aquelle doce encanto que lograva, engano, e fado foi: Quem cuidaria, que tanto bem taõ sêdo se acabava? Foraõ invejas do fado que sentîa o engano em q q. o meu bem tanto durava; por isso destinou, que hũ só momento fossem as horas do meu contentamento.

Do Amor, e Marte fui taõ combatido, como agora o estou de Amor, e Morte: O Marte trousse as ármas de Cupido; a Morte rendo agora as de mámorte: Meus enganos me trazem taõ perdido, e delles foy motivo a minha sorte; pois contra meu socego, tinham dado, as maõs o engano, e os ardis do fado.

Oh misero de mim! Como me vejo já arrependido deste triste engano? Que pouco dura o gosto de hum desejo, quando o fado o converte em desengano! Eu de mim $p^{a}$. mim meu damno elejo; mas no de Lidia he só mais desumano; pois quando julgo de meu trato a culpa, nem o engano, nem fado me desculpa. 
Deixarte, oh vida, foi fatalidade;

embarcarme sem tŷ, foi fero engano:

do meu engano chóro a falsidade;

do meu fado lamento o desengano:

De huã verdade passo a outra verdade,

e conspiradas ambas em meu dano,

padesso a pena de tirar duas vidas,

q̃. o engano, e fado tinhaõ sempre unidas.

$125 "$

Da gloria deste fado, e deste engano

formava a vida, e morte hũ doce jugo:

darme hoje o fado a vida, he ser tirano;

negarme o engano a morte, he ser verdugo:

Compassivo comigo, e desumano,

tórno a chorar as lagrimas que enxugo;

e he meu alivio o mesmo sentimento;

mas ter înda esse alivio o mór tormento.

Que importa contrapôr máres a máres, e aos impulsos do vento meus suspiros, se nem suspiros valem a meus pesáres, nem nos máres se impedem meus retiros?

Os suspiros em vaõ rompem os áres, quando os máres os naõ prevertem giros; mas que suspiro, ou mar, naõ mudaõ logo meu engano em vento, ou o meu fado em fogo? 
Oh quanto contra Armido fez o engano!

oh quanto contra Lidia pôde o fado!

o fado, lhe dispôs na gloria o dano;

o engano a mim nas ditas este estado!

Ambos, hum ser tivemos soberano

para o perdermos ambos desprezado:

oh se nunca passára de querernos,

naõ fôra logo a industria de perdernos!

128

Perdite, ou por engano do juizo,

ou por culpa do fado que o domina:

do fado, porque faz mais indeviso

o amor, que na presensa mais declina:

do juizo, por crêr que éra preciso

naõ te ver para amarte mais divina;

mas veyo a ser no effeito em tudo errado,

engano amarte mais; mais vêrte, fado.

Mas se fôra do fado acçaõ naõ verte,

podéra sentir menos o deixarte;

que a violencia do fado, emfim preverte

do mais astuto a morte, a forsa, e arte:

E se eu te deixo só por mais quererte,

e he o meu naõ verte mais, mais adorarte;

porque culpo o naõ verte, naõ culpado?

para que digo, ̃̃. o naõ verte he fado? 
$130 "$

Tambem se amarte mais engano fôra, naõ te adorára de mim mesmo ausente: ver, e adorar, he premio do que adora; que he gloria do adorar estar presente: Mas adorar sem ver, tanto melhora a fé, que faz o amor mais excellente; sendo este modo pois taõ soberano, amarte mais, naõ póde ser enagno.

Logo, se o engano, e fado, que eu culpava, mayores culpas contra mim fabricam; aquelle amor, e vida, que eu lograva, na primeira innocencia as qualificam: Naõ conhecia a gloria que gozava, e éstas mágoas agora o certeficam; porq̃. ignorava, entre o gozo, e riso, que coisa era viver no Paraîso.

Já neste inferno, aonde nunca apágam nem mar as penas, nem o vento as chamas, meus nescios êrros castigados pagam ésta alma em agoas, este peito em flamas: A minha vista a tua dor afagam aquellas que o cristal o sexo infamas, que hum, e outro remedio que festejo, saõ sombras do tormento q̃. em mim vejo. 
Se Sisipho, e se Tantalo estiveram

nos meus incendios, ou nas minhas mágoas,

oh como por alivio só tiveram

rodar as penhas, e anelar as agoas!

As mesmas penhas, e agoas concedêram,

que eram mais toleraveis q̃. éstas frágoas;

e eu Sesipho das agoas ser aspiro;

e Tantalo das penhas só suspiro.

Oh penhas, ̃̃. a meus olhos vos negastes!

oh que a delicia vós tambem perdestes!

Se com Lidia na vista vos ficastes,

como comigo ausentes vos viestes?

A pena de a perder mais augmentastes

no alivio com q̃. mais me entristecestes;

que se o bem das saudades he lembralas,

he menos o sentilas, que logralas.

Mas deixay que me aflijam desunidas

as saudades sentidas, ou logradas;

que se as logradas, saõ as mais validas,

sempre as sentidas saõ as mais lembradas:

As logradas, se perdem possuîdas;

as sentidas se logram suspiradas;

e eu nesta differensa só me privo

do alivio, e pena com ̃̃. morro, e vivo. 
Do alivio; porq̃. morra em dura pena:

da pena; porque sempre nella viva:

Quem busca alivio, á morte se condena:

Quem logra a morte, de sentir se priva.

A dor mais féra em mim he a mais serena:

a pena menos féra, he a mais esquiva;

que como o meu alivio he a dor mais forte,

morro da vida, e vivo só da morte.

Por isso me naõ matam as crueldades;

por isso me daõ vida os sentimentos:

da vida, e morte saõ perplexidades

crueis as glorias, doces os tormentos:

E he que daõ neste ardil as saudades

cobardias á vida, á morte alentos;

para que eu mais cobarde, que homicida,

dos alentos da morte forme a vida.

Mas quando tenho a vida mais ganhada, nessa morte emq̃. vivo, he mais perdida; porque a vida na morte transformada, da morte vital he mais homicida:

Oh vida, oh morte, por meu mal trocada!

Só eu dou vida á morte, á morte a vida:

Mas que digo? inda he mais confusa sorte naõ dever vida á vida, e morte á morte. 
Donde venho a inferir, q̃. morro, e vivo, sem ter vida, nem morte (oh sorte dura!) Na morte, sinto a pena de estar vivo: na vida, sinto a morte do que atura: Deste modo he meu mal taõ successivo, que sempre alterna berço, e sepultura; que junta ao sol, qual Fenix de seus rayos, sempre nasce do horrôr de seus desmayos.

Desta vida, só sinto a pouca dura, quando só sinto, oh Lidia, o durar tanto; pois perderte, e durar, triste loucura; durar para sentirte, doce encanto: Do sentir a fineza q̃. he mais pura, chega a matar quem vive em triste pranto;

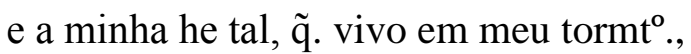
por sentir no sentir contentamento.

Mas ay, q̃. o gosto de sentir contente, he o tormento mayor de quanto peno! que gostar, e sentir conformemente, he beber a triaga no veneno: Hum coraçaõ de todo descontente, nem do que pena gosta por asseno; e assim, venho a penar no pressuposto de nem gostar da pena, nem do gosto. 
Este he o motivo, oh Lidia, oh doce Prenda

porq̃. inda sinto quando morro ausente;

que quer meu fado, q̃. culpado aprenda

a ser mais sensitivo, que vivente:

oh queira o teu amor q̃. nunca entenda

que o meu se deminuê em o que sente;

pois se em sentir ausente, se merece;

o meu nos sentimentos he que créce.

$143 "$

Oh quantas vezes viâ nestas horas

entre outro mar o ceo q̃. Venus teve!

suspenso o Sol, ocultas as Auroras,

dormir as flores em jardim de neve!

Athé que madrugando a ser senhoras

do carcere ditoso, que as deteve,

de seu perdido aljofar se sorrîam,

e ao dia as pontas, como a mim, se abriam.

$144 \prime$

Agora neste carcere de pinho,

corrente as agoas, e grilhoẽns o vento

atado ás cordas, e sogeito ao linho,

o meu delicto pago em meu tormento:

He prisaõ successiva este caminho,

onde sim tenho livre o pensamento;

e este me agrava a culpa de meus êrros,

e athé do vento, e mar me forja os ferros. 
Nos ferros geme o triste delinquente, de livrarse a esperansa já perdida, se no acabar entende sabiamente, que a fortuna melhora aborrecida: E de sofrer a vida impaciente, seu suplicio suspira á mesma vida; pois he nas penas dehuã trsite sorte, menos morte acabar na mesma morte.

Chora o charo consorte o doce ninho prêsa Avezinha, com saudoso pranto; mas convertendo o carcere em raminho, das tristes mágoas forma alegre canto: Faz coas queixas o amante Passarinho, aos passos suspensaõ, ao ouvido encanto; e tem nas ancias de se ver perdido, por discreta vaidade, o ser ouvido.

Descansa o delinquente em verse morto; e vive o Passarinho em verse ouvido: Eu só, do fado lastimoso aborto, nem na morte acho bem, nem no gemido: Que naõ quer este vento, e mar q̃. córto, verme morto, nem verme enternecido; mas he porq̃. naõ ache a meu tormento nos homẽns, nem nos brutos documt ${ }^{\circ}$. 
148

Neste tempo o Piloto vigilante,

que as Estrellas observa judicioso,

outra adverte, que usurpa sentilante

do vago vulgo o imperio luminoso:

Fixo especula, admira vacilante;

pois naõ visto farol do Reyno undoso,

he com resplendecente novidade,

injûria ao Ceo, ao Mar serenidade.

Repára o triste Armido; e escassamente

de Lidia as sombras vê naquelles rayos,

quando delles no peito ingrato sente

o effeito que apressou mais seus desmayos:

Dar docemente á vida descontente

fatal ecclipse a seus florîdos mayos,

supoẽm com sigo; e alî, com louco acordo,

ao mar se arroja do ceruleo bordo.

Ser hum tormt ${ }^{\circ}$. alivio aoutro tormento, experimenta quem sente a mayor pena; mas a gloria de hũ justo sentimento, sempre a pena mayor ácha pequena:

Que a fidalguia de hum querer isento, athé as finezas do sentir condena;

pois anelar sentir só por fineza, he merecer, e merecer vileza. 
Se Armido, morta Lidia, padecêra, seu mesmo padecer vivo infamára; pois quanto padecendo merecêra, sua injûria, vivendo, acressentára: Na mais intensa dôr, q̃. em vaõ sofrêra, lograra amor, e a vida preservára; e quem na vida funda o ser mais fino, na fineza eterniza o desatino.

Por isso Armido, sem discurso, acerta achar no pricipicio a sabia morte: Mas ay, ̃̃. naõ foi sua aquela incerta accçaõ da dôr, ou lástima da sorte; effeitos sim das almas, que encoberta dependencia mostrávaõ mais forte; pois reciprocamente conservadas, subsistir naõ podiam separadas.

Quando Armido no lenho se partia, quando Lidia na praya se ficava, Lidia no lenho o objecto he $\tilde{\text { q }}$ atendia, de sỹ Armido na praya se apartava: Aquella devisaõ que os desunîa, éra a uniaõ q̃. mais os transformava, clausulandose em tristes laberintos, indistinctos ao ser, e ávista extintos. 
Ao mesmo tempo Lidia, e Armido déram nova vida aos dous corpos, q̃. animáram; pois se entre ambos as vistas se perdêram, êntre ambos as duas almas se trocáram: Ambos a mesma gloria apetecêram; ambos o mesmo fim multiplicáram: Ella, da rocha ao mar se precipita; Elle, do bordo sem imitala, a imita.

Entre as sombras parece resoluta aquella maravilha, que éra Armido: a soberba de haver sido absoluta, parou no desengano de haver sido: A natureza toda resoluta, cobra o que nelle tinha dividido; e sendo cada parte mil portentos, ficou tudo hũ compendio de tormentos.

Fica o ser da eloquencia mais discreta, o emblema da elegancia mais polida, o inigma, $\tilde{q}$. ignorado se interpreta, a energia explicada mais sabida: O exemplo da graça, que secreta inda he mayor que sỹ, de sỹ abstrahida; cadaver triste, mas no mar q̃. infama, delicia do pinsel, mimo da fama. 
Sentida Venus, e anojado Marte,

unida pompa prevenira a Armido;

segue funesto o belico Estendarte,

roto o Arco do Deos já naõ seguido:

Dos maritimos quasi a mayor parte;

dos celestes o Deos mais preferido;

Venus no mar o leva a Lidia bella,

Marte nos Ceos a ser com Lidia Estrella.

158

O fim fatal de hũ, e de outro Amante, nas ondas, nas Estrellas se retrata:

O Olimpo fixa em estrellas de diamante;

e o Occeano em laminas de prata:

Ambos ûne a fortuna sempre errante;

ambos anima a fama nunca ingrata, authorizando em luzes essas palmas,

Neptuno os corpos, Jupiter as almas. 


\section{Referências bibliográficas}

\section{Fontes manuscritas}

ATAÍDE, António de. Borrador de hũa arte poetica que se intentava escreuer. Lisboa: Biblioteca da Ajuda, ms.46-VIII-37.

FARIA E SOUSA, Manuel de. Fuente de Aganipe o Rimas Varias. Parte V. Lisboa: Biblioteca Nacional de Lisboa, cod.13141.

. Fuente de Aganipe o Rimas Varias. Parte VI. Lisboa: Arquivo Nacional da Torre do Tombo, ms.440.

. Fuente de Aganipe o Rimas Varias. Parte VII. Évora: Biblioteca Pública de Évora, ms.CXIV/2-5.

Jardim cultivado com varias flores parnasianas nacidas de diversos engenhos, acumulandoas a este volume a curiosidade, para entertenimento do gosto. Braga: Biblioteca Pública de Braga, ms.130.

Metricas ociosidades em Varias Rimas. Desacordos da Musa, \& ociosa occupaçam da Penna. Por Joseph Correa de Brito. 1683. Lisboa: Biblioteca da Ajuda, ms.50-I1.

Miscelanea poetica. $5^{\circ}$ Tomo. Por Antonio Correya Vianna, 1776. Lisboa: Biblioteca da Ajuda, ms.49-III-65.

Obras em que se incluem Poezias e no fim alguma Proza de Antonio da Fonseca Soares que depois se chamou na Religiã̃ Fr. Antonio das Chagas... $2^{\circ}$ Tomo. Por Antonio Correya Vianna, 1776. Lisboa: Biblioteca da Ajuda, ms.49-III-75.

Obras em que se incluem Romances Lyricos de Antonio da Fonseca Soares... $4^{\circ}$ Tomo.

Por Antonio Correya Vianna, 1777. Lisboa: Biblioteca da Ajuda, ms.49-III-77.

Obras em que se incluem Romances Liricos de Antonio da Fonseca Soares... $5^{\circ}$ Tomo.

Por Antonio Correya Vianna, 1777. Lisboa: Biblioteca da Ajuda, ms.49-III-78.

Obras em que se incluem Romances Liricos Castelhanos de Antonio da Fonseca Soares... $6^{\circ}$ Tomo. Por Antonio Correya Vianna, 1777. Lisboa: Biblioteca da Ajuda, ms.49-III-79. 
Obras Poeticas de Antonio da Fonseca Soares chamdo (sic) depois na Relligiaõ Fr. Antonio das Chagas... $7^{\circ}$ Tomo. Por Antonio Correya Vianna, 1782. Lisboa: Biblioteca da Ajuda, ms.49-III-80.

Obras Poeticas de Antonio da Fonseca Soares chamado depois na Religião Fr. Antonio das Chagas... $8^{\circ}$ Tomo. Por Antonio Correya Vianna, 1783. Lisboa: Biblioteca da Ajuda, ms.49-III-81.

\section{Fontes impressas}

A Bíblia de Jerusalém. Nova edição, revista. São Paulo: Paulus, 1995.

A Fenix Renascida ou obras poeticas dos melhores engenhos portuguezes. Publica-o Mathias Pereira da Sylva. Lisboa Occidental: na Officina de Antonio Pedrozo Galram, 1716-1728, 5 Tomos.

A Fenix Renascida ou obras poeticas dos melhores engenhos portuguezes. Segunda vez impresso e acrescentado por Mathias Pereira da Sylva. Lisboa: Offic. dos Herd. de Antonio Pedrozo Galram, 1746, 5 Tomos.

ALMEIDA, Manuel Pires de. Discurso sobre o Poema Heróico. Edição e comentário de Adma Muhana. REEL - Revista Eletrônica de Estudos Literários, Vitória, a.2, n.2, 2006, pp.1-22. Disponível em: http://www.ufes.br/ mlb/reel2/ AdmaMuhana. pdf.

Poesia e Pintura ou Pintura e Poesia: tratado seiscentista de Manuel Pires de Almeida. Edição de Adma Muhana. São Paulo: Fapesp; Edusp, 2002.

ARISTÓTELES. De Anima. Apresentação, tradução e notas de Maria Cecília Gomes dos Reis. São Paulo: Editora 34, 2006.

Ética a Nicômacos. Tradução de Mário da Gama Kury. 3ªed. Brasília: Editora da Universidade de Brasília, 1999.

Poética. Tradução, prefácio, introdução, comentário e apêndices de Eudoro de Sousa. $8^{a}$ edição. Lisboa: Imprensa Nacional - Casa da Moeda, 2008.

Retórica. Tradução e notas de Manuel Alexandre Júnior, Paulo Farmhouse Alberto e Abel do Nascimento Pena. Lisboa: Imprensa Nacional - Casa da Moeda, 1998.

ARNIM, Hans Friedrich August von. Stoicorum veterum fragmenta. 4v. Lipsiae: in aedibus B.G. Teubneri, 1903-24. 
Arte de trovar do Cancioneiro da Biblioteca Nacional de Lisboa. Introdução, edição crítica e fac-símile por Giuseppe Tavani. Lisboa: Edições Colibri, 2002.

BACELAR, Antônio Barbosa. Desafio venturoso. Organização e prefácio de Ana Hatherly. Lisboa: Assírio \& Alvim, 1991.

- Obras Poéticas de António Barbosa Bacelar (1610-1663). Edição de Mafalda Ferin Cunha. Lisboa: Fundação Calouste Gulbenkian, 2007.

BAÍA, Frei Jerônimo. Arde o mar: poesia de Jerónimo Baía n’ A Fénix Renascida. Edição, selecção, estudo, notas e apêndice de Filipe Diez. Santiago de Compostela: Laiovento, 1999.

. Lampadário de cristal. Apresentação crítica, fixação do texto, motas, glossário e roteiro de leitura de Ana Hatherly. Lisboa: Comunicação, 1992.

Base de datos da Lírica Profana Galego-Portuguesa (MedDB), versión 2.3.3. Santiago de Compostela, Galicia: Centro Ramón Piñeiro para a Investigación en Humanidades. Disponível em: http://www.cirp.es/.

BEMBO, Pietro. Gli Asolani. In: Prose della volgar lingua; Gli Asolani; Rime. A cura di Carlo Dionisotti. Milano: TEA, 1989.

BERNARDES, Diogo. Obras completas. Volume I: Rimas Várias; Flores do Lima. Prefácio e notas de Marques Braga. Lisboa: Sá da Costa, 1945.

BLUTEAU, Raphael. Vocabulario Portuguez, \& Latino. Coimbra: No Collegio das Artes da Companhia de Jesu, 1712-1713, vols.1-4. Lisboa Occidental: Na Officina de Pascoal da Sylva, 1716-1721, vols. 5-8. Suplemento ao Vocabulario Portuguez, e Latino. 2v. Lisboa Occidental: Na Officina de Joseph Antonio da Sylva, 1727; Na Patriarcal Officina da Musica, 1728. Edição fac-similada: Hildesheim; Zürich; New York: Georg Olms Verlag, 2002. 10v.

BORRALHO, Manoel da Fonseca. Luzes da Poesia descubertas no Oriente de Apollo nos influxos das Muzas, divididas em tres Luzes essenciaes... Lisboa: na Officina de Felippe de Sousa Villela, 1724.

CAMÕES, Luís Vaz de. Obra Completa. Organização, introdução, comentários e anotações de Antônio Salgado Júnior. Rio de Janeiro: Nova Aguilar, 2005.

CAPELÃO, André. Tratado do amor cortês. Introdução, tradução do latim e notas de Claude Buridant; tradução de Ivone Castilho Benedetti. São Paulo: Martins Fontes, 2000.

CASCALES, Francisco. Tablas Poeticas. Murcia: por Luis Beros, 1617. 
CASTIGLIONE, Baldassare. O cortesão. Tradução de Carlos Nilson Moulin Louzada. São Paulo: Martins Fontes, 1997.

CÍCERO. De l'orateur. Texte établi et traduit par Edmond Courbard. Paris : Les Belles Lettres, 1950.

. L'orateur: du meilleur genre d'orateurs. Texte établi et traduit par Albert Yon. Paris : Les Belles Lettres, 1964.

Tusculanes. Texte établi par Georges Fohlen et traduit par Jules Humbert.

Paris : Les Belles Lettres, 1997.

CORREIA, Natália. Antologia da poesia do período barroco. Lisboa: Moraes editores, 1982.

DIÓGENES LAÉRCIO. Vidas e doutrinas dos filósofos ilustres. Tradução do grego, introdução e notas Mário da Gama Kury. Brasília: UnB, 1997.

DU VAIR, Guillaume. De la constance et consolation és calamitez publiques. Paris: par Mamert Parisson, Impremeur du Roy. Chez Rob. Estienne, 1594.

De la Sainte Philosophie ; Philosophie Morale des Stö̈ques. Édition annotée par G. Michaut. Paris : J. Vrin, 1945.

Eccos que o Clarim da Fama dá: Postilhão de Apolo. Por Joseph Maregelo de Osan.

Lisboa: Offic. de Francisco Borges de Souza, 1761-1762, 2 Tomos.

EPICTETO. Enquiridon. Estudio introductorio, traducción y notas de José Manuel Garcia de la Mora. En apéndice, la versión parafrástica de D. Francisco de Quevedo y Villegas. Barcelona: Anthropos; Madrid: MEC, 1991.

Entretiens. Texte établi et traduit par Joseph Souilhe. Paris : Les Belles Lettres, 1948-1995. 4t.

. Manual de Epiteto filosofo. Trad. Frei Antonio de Souza. São Paulo: Cultura, s/d.

The Discourses as reported by Arrain, the Manual, and Fragments. With an english translation by R.D. Hicks. Cambridge, Mass.; London: Harvard University Press, 1998. 2v.

EPICURO. Antologia de textos de Epicuro. Tradução e notas de Agostinho da Silva. In: Os Pensadores. Volume V. São Paulo: Abril Cultural, 1973.

FARIA E SOUSA, Manuel de. Fuente de Aganipe o Rimas Varias. Parte Primera. Madrid: Carlos Sánchez Bravo, 1646.

. Fuente de Aganipe o Rimas Varias. Parte Segunda. Madrid: Juan Sánchez, 1644. 
Fuente de Aganipe o Rimas Varias. Parte Tercera. Madrid: Carlos Sánchez Bravo, 1646.

. Fuente de Aganipe o Rimas Varias. Parte Quarta. Madrid: Juan Sánchez, 1644.

FICINO, Marsílio. Commentaire sur le Banquet de Platon, De l'Amour Commentarium in Convivium Platonis, De Amore. Texte établi, traduit, présenté et annoté par Pierre Laurens. Paris: Les Belles Lettres, 2002.

GARCILASO DE LA VEGA. Obra poética y textos en prosa. Edición de Bienvenido Morros. Barcelona: Crítica, 2007.

GÓNGORA, Luis de. Obras Completas. Recopilación, prólogo y notas de Juan Millé y Giménez y Isabel Millé y Giménez. Madrid: Aguilar, 1972.

. Fábula de Polifemo y Galatea. Edición de Alexander A. Parker. Madrid:

Cátedra, 2007.

. Soledades. Edición de John Beverley. Madrid: Cátedra, 2007.

. Sonetos Completos. Edición introducción y notas de Biruté Ciplijauskité.

Madrid: Castalia, 1992.

GRACIÁN, Baltasar. Agudeza y Arte de Ingenio (Huesca, Juan Nogués, 1648). Edición facsímil. Estudio preliminar de Aurora Egido. Zaragoza: Institución «Fernando el Católico», 2007. . Obras completas de Baltasar Gracián. 2v. Madrid: Turner, 1993.

HALICARNASSO, Dionísio de. Tratado da Imitação. Editado por Raul Miguel Rosado Fernandes. Lisboa: Instituto Nacional de Investigação Científica; Centro de Estudos Clássicos das Universidades de Lisboa, 1986.

HEBREU, Leão. Diálogos de amor. Tradução de Giacinto Manuppella. Lisboa: Imprensa Nacional - Casa da Moeda, 2001.

HESÍODO. Teogonia: a origem dos deuses. Estudo e tradução de Jaa Torrano. Iluminuras, 2006.

HORÁCIO. Arte Poética. Introdução, tradução e comentários de R. M. Rosado Fernandes. Lisboa: LCE, s/d (coleção bilíngüe). . Euvres Complètes. 2t. Texte établi par François Richard. Paris : Garnier Frères, 1950.

JÁUREGUI, Juan de. Antídoto contra la pestilente poesía de las Soledades. Estudio y edición crítica de José Manuel Rico García. Sevilla: Secretariado de Publicaciones de la Universidad de Sevilla, 2002. 
LEITÃO FERREIRA, Francisco. Nova Arte de Conceitos. 2v. Lisboa Occidental: Antonio Pedrozo Galram, 1718 e 1721.

LÍPSIO, Justo. De Constantia libri duo. Antuerpiae : Ex Officina Plantiniana : Apud Joannem Moretum, 1599.

. Les Deux Livres de la Constance: Esquels en forme de devis familier est discouru des afflictions, et principalement des publiques, et comme il se faut résoudre à les supporter. Traduction anonyme du latin. Edition de Tours (1592). Paris : Noxia, 2000.

. Opera omnia. Antuerpiae: Ex Officina Plantiniana Balthasaris Moreti, 1637. $4 \mathrm{t}$.

LOBO, Francisco Rodrigues. Corte na Aldeia e Noites de Inverno. Prefácio e notas de Afonso Lopes Vieira. $2^{\text {a }}$ ed. Lisboa: Sá da Costa, 1959.

. Poesias. Selecção, prefácio e notas de Afonso Lopes Vieira. 2 $2^{\mathrm{a}}$ ed. Lisboa:

Sá da Costa, 1955.

LOPES, Graça Videira; FERREIRA, Manuel Pedro et al. (2011-). Cantigas Medievais Galego Portuguesas [base de dados online]. Lisboa: Instituto de Estudos Medievais, FCSH/NOVA. Disponível em: http://cantigas.fcsh.unl.pt.

LUCRÉCIO. Da natureza. Tradução e notas de Agostinho da Silva. In: Os Pensadores. Volume V. São Paulo: Abril Cultural, 1973.

. De la nature / De rerum natura. Traduction, introduction et notes de José Kany-Turpin. Paris: GF Flammarion, 1997.

Lusiadas de Luis de Camões comentadas por Manuel de Faria e Sousa. Edição facsimilar. 2v. Lisboa: Imprensa Nacional - Casa da Moeda, 1972.

MACHADO, Diogo Barbosa. Bibliotheca Lusitana. Tomo I. Lisboa Occidental: Na Officina de Antonio Isidoro da Fonseca, 1741.

. Bibliotheca Lusitana. Tomo III. Lisboa: na Officina de Ignacio Rodrigues, 1752.

MARINO, Giambattista. Amori. Introduzione e note di Alessandro Martini. Milano: Rizzoli, 2002.

. L'Adone. A cura di Marzio Pieri e Luana Salvarani. Trento: La Finestra, 2007.

MATOS, Gregório de. Crônica do Viver Baiano Seiscentista: obra poética completa; códice James Amado. 2v. 4ªed. Rio de Janeiro: Record, 1999. 
MEDRANO, Juan de Espinosa. Apologetico en favor de D. Luis de Gongora, Principe de los Poetas Lyricos de España: Contra Manuel de Faria y Sousa, Cavallero Portugues. En Lima: En la Imprenta de Juan de Quevedo y Zarate, 1694.

MELO, Francisco Manuel de. Apólogos dialogais. Prefácio e notas do José Pereira Tavares. 2v. Lisboa: Sá da Costa, 1959.

A tuba de Calíope: quarta musa das Obras Métricas. Introdução, estabelecimento do texto, notas e glossário por Segismundo Spina. São Paulo: Brasiliense; EDUSP, 1988.

Obras Métricas. Edição coordenada por Maria Lucília Gonçalves Pires e José Adriano de Freitas Carvalho. 2v. Braga: Edições APPACDM, 2006.

. Obras Morales de Don Francisco Manuel a la Serenissima Reyna Catalina, Reyna de la Gran Bretaña. 2v. Roma: Falco, 1664.

NUNES, Philippe. Arte Poetica, e da Pintura, y Simmetrya, com principios da perspectiva. Lisboa: por Pedro Crasbeeck, 1615.

OLIVEIRA, Manuel Botelho de. Música do Parnaso. Edição fac-similar [1705]. Organização e estudo crítico de Ivan Teixeira. Cotia: Ateliê Editorial, 2005. Poesia completa: Música do Parnasso, Lira Sacra. Introdução, organização e fixação de texto Adma Muhana. São Paulo: Martins Fontes, 2005.

OROZCO, Sebastián de Covarrubias. Tesoro de la Lengua Castellana, o Española. En Madrid: por Luis Sanchez, 1611.

OVÍDIO. L'art d'aimer. Texte établi et traduit par Henry Bornecque. Huitième édition revue et corrigée par Philippe Heuzé. Paris: Les Belles Lettres, 2002.

. Les amours. Texte établi et traduit par Henri Bornecque. Paris: Les Belles Lettres, 2009.

PEREGRINI, Matteo. Delle Acutezze. Teste e note a cura di Erminia Ardissino. Torino: Edizioni Res, 1997. (Alethes, Collezione di Retorica, n.4).

PETRARCA, Francesco. Canzoniere. Torino: Einaudi, 1992.

PINCIANO, Alonso López. Philosophía Antigua Poética. Obras completas, I. Edición de José Rico Verdú. Madrid: Biblioteca Castro, 1998.

PLATÃO. O Banquete - Apologia de Sócrates. Tradução de Carlos Alberto Nunes. $2^{\mathrm{a}}$ ed. rev. Belém: EDUFPA, 2001.

PLUTARCO. Érotikos: dialogue sur l'amour. Texte établi et traduit par Robert Flacelière. Paris: Les Belles Lettres, 2008.

Poesía lírica del Siglo de Oro. Edición de Elías L. Rivers. Madrid: Cátedra, 2005. 
Poesia lírica latina. Organização de Maria da Glória Novak e Maria Luiza Neri. $3^{\text {a ed. }}$

São Paulo: Martins Fontes, 2003.

Poesia maneirista. Apresentação, seleção e notas de Isabel Almeida. Lisboa: Comunicação, 1998.

Poesia seiscentista - Fênix renascida \& Postilhão de Apolo. Organização de Alcir

Pécora; Introdução de João Adolfo Hansen São Paulo: Hedra, 2002.

Poetas do período barroco. Apresentação, seleção e notas de Maria Lucília Gonçalves Pires. Lisboa: Comunicação, 1985.

PORTUGAL, D. Franciso de. Arte de galantería. Edição e notas de José Adriano de Freitas Carvalho. Porto: Centro Inter-Universitário de História da Espiritualidade; Faculdade de Letras da Universidade do Porto, 2012.

. Divinos e humanos versos. Introdução e notas de Maria Lucília Gonçalves

Pires. Porto: Centro Inter-Universitário de História da Espiritualidade; Faculdade de Letras da Universidade do Porto, 2012.

QUEVEDO, Franciso de. Los sueños. Edición de Ignacio Arellano. Madrid: Cátedra, 2003.

. Obras completas. Tomo I: Obras en prosa. 6ª ed. Madrid: Aguilar, 1992.

. Poesía original completa. Edición, introducción y notas de José Maneul

Blecua. Barcelona: Planeta, 2004.

QUINTILIANO. Institution Oratoire. Texte établi et traduit par Jean Cousin. Paris: Les Belles Lettres, 1975-1980.

REBELO, Gaspar Pires de. Infortúnios Trágicos da Constante Florinda. Edição de Artur Henrique Ribeiro Gonçalves. Tese para a obtenção do grau de doutor. Lisboa: Universidade Nova de Lisboa, 2000.

Infortúnios trágicos da Constante Florinda. Edição de Nuno Júdice. Lisboa:

Teorema, 2005.

. Infortúnios trágicos da constante Florinda. Organização, notas e posfácio de Adma Muhana. São Paulo: Globo, 2006.

RENGIFO, Juan Diaz. Arte poetica española. Madrid: Viuda de Alonso Martin, 1628.

Retórica a Herênio. Tradução e introdução Ana Paula Celestino Faria e Adriana Seabra.

São Paulo: Hedra, 2005.

Rimas Varias de Luis de Camoens... Comentadas por Manuel de Faria y Sousa.

Primeira Parte. Lisboa: En la Imprenta de Theotonio Damaso de Mello Impressor de la Casa Real, 1685. 
Rimas Varias de Luis de Camoens... Comentadas por Manuel de Faria y Sousa. Segunda Parte. Lisboa: En la Imprenta Craesbeeckiana, 1688.

SÁ DE MIRANDA, Francisco. Obras Completas. 2v. Texto fixado, notas e prefácio de Rodrigues Lapa. $5^{\text {a }}$ edição. Lisboa: Sá da Costa, 2002.

SANTILLI, Maria Aparecida e SPINA, Segismundo. Apresentação da poesia barroca portuguesa. Assis: Faculdade de Filosofia, Ciências e Letras de Assis, 1967.

SANTO AGOSTINHO. A Cidade de Deus. Tradução, prefácio, nota biográfica e transcrições de J. Dias Pereira. 2ªed. Lisboa: Fundação Calouste Gulbenkian, 1996.

A doutrina cristã: manual de exegese e formação cristã. Trad. Nair de Assis Oliveira. São Paulo: Paulus, 2002.

. L'istruzione cristiana. A cura di Manlio Simonetti. Verona: Arnoldo Mondadori, 1994.

SÊNECA. Cartas a Lucílio. Tradução, prefácio e notas J.A. Segurado e Campos. Lisboa: Fundação Calouste Gulbenkian, 2004.

De Constantia sapientis. Commentaires par Pierre Grimal. Paris : Les Belles Lettres, 1953.

. De ira. Dialogues, t.1. Texte établi et traduit par A. Bourgery. Paris: Les Belles Lettres, 1951.

. Sobre a brevidade da vida. Tradução, notas e introdução de William Li. Edição bilíngüe. São Paulo: Nova Alexandria, 1993.

. Sobre a Divina Providência e Sobre a Firmeza do Homem Sábio. Tradução, introdução e notas de Ricardo da Cunha Lima. Edição bilíngüe. São Paulo: Nova Alexandria, 2000.

. Sobre a tranqüilidade da alma; Sobre o ócio.Tradução, introdução e notas de José Rodrigues Seabra Filho. Edição bilíngüe. São Paulo: Nova Alexandria, 1994.

. Sobre a vida feliz. Tradução, notas e introdução de João Teodoro d'Olim Marote. Edição bilíngüe. São Paulo: Nova Alexandria, 2005.

TASSO, Torquato. Discorsi dell'Arte Poetica e in particolare sopra il Poema Eroico.

In: Prose. A cura de Ettore Mazzali. Milano, Napoli: Riccardo Ricciardi, 1959, pp.349-410.

Discorsi del Poema Eroico. In: Prose. Milano: Rizzoli, 1935, pp.315-539. 
TESAURO, Emanuele. Il Cannocchiale Aristotelico (1654). Torino: Per Battolomeo Zavatta, 1670.

The cancionero Manuel de Faria: a critical edition with introduction and notes by Edward Glaser. Münster, Westfalen : Aschendorffsche, 1968.

TORELLI, Pomponio. Poesie con il Trattato della poesia lirica. Introduzione di R. Rinaldi, testi, commenti critici e apparati a cura di N. Catelli, A. Torre, A. Bianchi e G. Genovese. Parma: Guanda, 2008.

Trattato della poesia lirica. Roma: Biblioteca Italiana, 2003. Disponível em: http://www.bibliotecaitaliana.it./indice/visualizza_scheda/bibit000505.

Trattati di poetica e di retorica del Cinquecento. A cura di B. Weinberg. V.4. Bari: Laterza, 1974.

VARNHAGEN, Franciso Adolfo de. Florilegio da Poesia Brazileira. Tomo I. Lisboa: Imprensa Nacional, 1850.

VIOLANTE DO CÉU. Parnaso Lusitano de divinos, e humanos versos. Lisboa Occidental: na Officina de Miguel Rodrigues, 1733. Rimas Várias. Introdução, notas e fixação do texto de Margarida Vieira Mendes. Lisboa: Editorial Presença, 1994.

\section{Estudos}

ACHCAR, Francisco. Lírica e lugar-comum: alguns temas de Horácio e sua presença em português. São Paulo: Edusp, 1994.

AGUIAR E SILVA, Vítor Manuel de. Maneirismo e barroco na poesia lírica portuguesa. Coimbra: Centro de Estudos Românicos, 1971.

ALMEIDA, Carmelina Magnavita Rodrigues de. O Marinismo de Botelho. Tese apresentada ao Instituto de Letras da Universidade Federal da Bahia para concurso de Professor Assistente do Departamento de Letras Românicas. Salvador, 1975.

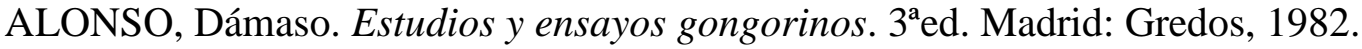
. Góngora y el "Polifemo”. Madrid: Gredos, 1967.

ASKINS, Arthur L.-F. "Os inéditos camonianos de Manuel de Faria e Sousa”. In: Critique textuelle portugaise. Actes du Colloque, Paris, 20-24 octobre 1981. Paris: Fondation Calouste Gulbenkian; Centre Culturel Portugais, 1986, pp.219226. 
AUERBACH, Erich. Figura. Tradução de Duda Machado. São Paulo: Ática, 1997.

Le Culte des passions: Essais sur le XVII siècle français. Introduction et traduction par Diane Meur. Paris : Macula, 1998.

BARTHES, Roland. “A retórica antiga". In: COHEN et al. Pesquisas de retórica. Petrópolis: Vozes, 1975.

BATAILlON, Marcel. Erasmo y España. Traducción de Antonio Alatore. México, D. F.: Fondo de Cultura Económica, 1996.

BERNUCCI, Leopoldo M. "Disfraces gongorinos en Manuel Botelho de Oliveira". In: Cuadernos Hispanoamericanos, n.570, Madrid, 1997, pp.73-94.

BLÜHER, Karl Alfred. Séneca en España: investigaciones sobre la recepción de Séneca en España desde el siglo XIII hasta el siglo XVII. Versión española de Juan Conde. Edición corregida y aumentada. Madrid: Gredos, 1983.

BRANDÃO, Roberto de Oliveira. Poética e poesia no Brasil (Colônia). São Paulo: Editora UNESP; Imprensa Oficial do Estado, 2001.

CARABIN, Denise. Les idées stö̈ciennes dans la littérature morale des XVI et XVII siècles (1575-1642). Paris: Champion, 2004.

CÁRDENAS, Jesús Ponce. Góngora y la poesía culta del siglo XVII. Madrid: Laberinto, 2001.

CARVALHO, José Adriano de. “A poesia sacra de D.Francisco Manuel de Melo”. In: Arquivos do Centro Cultural Português. Paris: Fundação Calouste Gulbenkian, 1974, pp. 295-404.

CARVALHO, Maria do Socorro Fernandes de. Poesia de agudeza em Portugal: estudo retórico da poesia lírica e satírica escrita em Portugal no século XVII. São Paulo: Humanitas; Edusp; Fapesp, 2007.

CASTRO, Aníbal Pinto de. "Os códigos poéticos em Portugal do Renascimento ao Barroco. Seus fundamentos, seus conteúdos, sua evolução". In: Separata da Revista da Universidade de Coimbra, vol.31, 1984, pp.505-532. - Retórica e teorização literária em Portugal: do Humanismo ao Neoclassicismo. $2^{\mathrm{a}}$ ed. Lisboa: Imprensa Nacional - Casa da Moeda, 2008.

CASTRO, Ivo José de. Frei Jerónimo Baía (edição crítica de 6 poemas e estudo do vocabulário). Dissertação de Licenciatura em Filologia Românica, Universidade de Lisboa, 1969. 
CHASTEL, André. "Le Baroque et la Mort". In : Retorica e Barocco. Atti del III Congresso Internazionale di Studi Umanistici. A cura di Enrico Castelli. Roma: Fratelli Bocca, 1935, pp.33-46.

CIDADE, Hernani. A poesia lírica cultista e conceptista. Lisboa: Seara Nova, 1968.

CIORDIA, Martín José. Amar en el Renacimiento: un estudio sobre Ficino y Abravanel. Buenos Aires: Universidad de Buenos Aires, Facultad de Filosofia y Letras: Miño y Davila, 2004.

CIRURGIÃO, Antônio. A sextina em Portugal nos séculos XVI e XVII. Lisboa: Instituto de Cultura e Língua Portuguesa. Biblioteca Breve / Volume 126. 1ª edição, 1992.

CORDEIRO, Adriano Milho. Registos sobre um Borrador de huma arte poética que se intentava escrever. Torres Novas: Gráfica Almondina, 2008.

COSTA, João Manuel Tavares da. A Poética de Manuel de Faria e Sousa. Dissertação de Mestrado em Literaturas Clássicas apresentada à Faculdade de Letras da Universidade de Coimbra, 1996.

CUNHA, Celso Ferreira da. Estudos de versificação portuguesa (séculos XIII a XVI). Paris: Fundação Calouste Gulbenkian; Centro Cultural Português, 1982.

CUNHA, Maria de Lourdes dos Santos. A Poética de António Barbosa Bacelar. Dissertação para Licenciatura em Filologia Românica apresentada à Faculdade de Letras da Universidade de Lisboa, 1961.

CURTIUS, Ernest Robert. Literatura Européia e Idade Média Latina. Tradução de Teodoro Cabral, com a colaboração de Paulo Rónai. 2aed. Brasília: Instituto Nacional do Livro, 1979.

DAUVOIS, Nathalie. Le sujet lyrique à la Renaissance. Paris: PUF, 2000. - La vocation lyrique: la poétique du recueil lyrique en France à la Renaissance et le modèle des Carmina d'Horace. Paris: Garnier, 2010.

EARLE, T. F. Tema e imagem na poesia de Sá de Miranda. Tradução de Isabel Penha Ferreira. Lisboa: Imprensa Nacional - Casa da Moeda, 1985.

ECHARRI, Emiliano Diez. Teorías Métricas del Siglo de Oro: apuntes para la historia del verso español. Madrid: Consejo Superior de Investigaciones Cientificas, 1949.

ETTINGHAUSEN, Henry. Francisco de Quevedo and the Neostoic Movement. Oxford: Oxford University Press, 1972.

FESTUGIÈRE, Jean. La philosophie de l'amour de Marsile Ficin - et son influence sur la littérature française au XVI ${ }^{e}$ siècle. Paris: J. Vrin, 1941.

FLACELIÈRE, Robert. L'amour en Grèce. Paris: Hachette, 1960. 
FLASCHE, Hans. "O método de comentar de Manuel de Faria e Sousa (contributo para a interpretação d'Os Lusíadas)". In: Actas da I Reunião Internacional de Camonistas. Lisboa: Comissão Executiva do IV Centenário da Publicação de «Os Lusíadas», 1973.

FONSECA, Maria do Céu Brás da. Uma Leitura de Camões por António Barbosa Bacelar. Edição de Sonetos. Dissertação de Mestrado em Literatura Portuguesa apresentada à Faculdade de Letras da Universidade de Lisboa, 1992.

FONTES, Joaquim Brasil. Eros, tecelão de mitos: a poesia de Safo de Lesbos. São Paulo: Iluminuras, 2003.

FOUCAULT, Michel. Les mots et les choses : Une archéologie des sciences humaines. Paris : Gallimard, 2007.

FUMAROLI, Marc. L’âge de l'éloquence: rhétorique et "res literaria" de la Renaissance au seuil de l'époque classique. Paris: Albin Michel, 1996.

GIGANDET, Alain. "Lucrécio e o amor conjugal. Um remédio para a paixão?" In: Besnier, B.; Moreau, P. F.; Renault, L. (orgs.). As paixões antigas e medievais: teorias e críticas das paixões. Tradução de Miriam Campolina Diniz Peixoto; revisão técnica de Mariana Paolozzi Sérvulo da Cunha. São Paulo: Edições Loyola, 2008.

GILSON, Étienne. Introduction à la philosophie chrétienne. Paris : J. Vrin, 1960. Introduction à l'étude de Saint Augustin. Paris : J. Vrin, 1982.

GLASER, Edward. Estudios Hispano-Portugueses : relaciones literarias del siglo de oro. Madrid : Castalia, 1957

GOMES JÚNIOR, Guilherme Simões. Palavras peregrina : o barroco e o pensamento sobre artes e letras no Brasil. São Paulo : EDUSP, 1998.

GRIMAL, Pierre. Le lyrisme à Rome. Paris : PUF, 1978.

HANSEN, João Adolfo. “Agudezas seiscentistas”. In: Floema Especial - Ano II, n. 2 A, pp. 85-109, out. 2006.

Alegoria - construção e interpretação da metáfora. São Paulo: Hedra; Campinas: Editora da Unicamp, 2006.

. A sátira e o engenho: Gregório de Matos e a Bahia do século XVII. $2^{\mathrm{a}} \mathrm{ed}$. rev. São Paulo: Ateliê Editorial; Campinas: Editora da Unicamp, 2004. . "Barroco, Neobarroco e Outras Ruínas". In: REEL - Revista Eletrônica de Estudos Literários. Vitória, a.2, n.2, 2006, pp.1-60. Disponível em: http://www.ufes.br/ mlb/reel2/ JoaoAdolfoHansen.pdf. 
. “Categorias epidíticas da ekphrasis". In: Revista USP, São Paulo, n.71, 2006

. "Fênix renascida \& Postilhão de Apolo: Uma introdução". In: Poesia seiscentista - Fênix renascida \& Postilhão de Apolo. $1^{\text {a }}$ ed. São Paulo: Hedra, 2002, pp.19-71.

. "Retórica da agudeza". In: Letras Clássicas, São Paulo, USP, n.4, 2000, pp.317-342.

- "Ut pictura poesis e verossimilhança na doutrina do conceito no século XVII”. In: Para Segismundo Spina: Língua, Filologia, Literatura. São Paulo: Edusp; Iluminuras, 1995, pp.201-214.

HATHERLY, Ana. "Homenagem a Jerónimo Baía no terceiro centenário da sua morte". In: Claro-Escuro: Revista de Estudos Barrocos. Lisboa: Quimera, 1988, pp.89109.

"Labirintos da Parte VII da Fuente de Aganipe de Manuel de Faria e Sousa". In: Separata dos Arquivos do Centro Cultural Português. XXI. Paris - Lisboa: Fundação Calouste Gulbenkian, 1985, pp.439-467.

- "Reescrita e Inovação Barroca: António Barbosa Bacelar vs. Luís de Camões”. In: Estudos portugueses: homenagem a António José Saraiva. Lisboa: Ministério da Educação, Instituto de Cultura e Língua Portuguesa; Faculdade de Letras da Universidade de Lisboa, 1990, pp.31-46.

JAEGER, Werner. Cristianismo primitivo e Paideia grega. Tradução de Teresa Louro Perez. Lisboa: Edições 70, 2002.

. Paidéia: A Formação do Homem Grego. Tradução Artur M. Parreira. $4^{\mathrm{a}}$ ed. São Paulo: Martins Fontes, 2001.

KLEIN, Robert. A forma e o inteligível: escritos sobre o renascimento e arte moderna. Tradução de Cely Arena; revisão técnica de Leon Kossovitch e Elisa Angotti Kossovitch. São Paulo: Edusp, 1998.

KRISTELLER, Paul. Tradição clássica e pensamento do Renascimento. Tradução de Artur Morão. Lisboa : Edições 70, 1995.

LAGRÉE, Jacqueline. Juste Lipse et la Restauration du Stö̈cisme. Paris: J. Vrin, 1994.

LAUSBERG, Heinrich. Elementos de Retórica Literária. Tradução, prefácio e aditamentos de R. M. Rosado Fernandes. 5aad. Lisboa: Fundação Calouste Gulbenkian, 2004. 
. Manual de Retórica Literaria: fundamentos de una ciencia de la literatura.

Versión española de José Pérez Riesco. Tomo I. Madrid: Gredos, 1975.

. Manual de Retórica Literaria: fundamentos de una ciencia de la literatura.

Versión española de José Pérez Riesco. Tomo II. Madrid: Gredos, 2003.

. Manual de Retórica Literaria: fundamentos de una ciencia de la literatura.

Versión española de José Pérez Riesco. Tomo III. Madrid: Gredos, 1994.

Le stö̈cisme au XVI et au XVII siècle: Le retour des philosophies antiques à l'âge

classique. Tome I. Sous la direction de Pierre-François Moreau. Paris: Albin Michel, 1999.

LÓPEZ GRIGERA, Luisa. Anotações de Quevedo à Retórica de Aristóteles. Tradução de Paulo Vasconcellos e Cássio Borges. Campinas: Editora da Unicamp, 2008. La Retórica en la España del Siglo de Oro. Salamanca: Universidad de Salamanca, 1994.

LUND, Christopher Chapman. Conceptismo in three seventeenth-century portuguese poets: António Barbosa Bacelar, Jerónimo Baía, and António da Fonseca Soares. Dissertation presented to the Faculty of the Graduate School of the University of Texas at Austin in Partial Fulfillment for the Degree of Doctor of Philosophy. Austin, august, 1974.

. "Fr. Jerónimo Baía and the semantics of wit". In: Separata dos Arquivos do Centro Cultural Português. XXI. Lisboa-Paris: Fundação Calouste Gulbenkian, 1985, pp.399-438.

MALDONADO, Maria Hermínia. "António da Fonseca Soares (Frei António das Chagas) - Trinta romances inéditos”. In: Boletim da Biblioteca da Universidade de Coimbra, vol. XLI, pp.407-495.

MANUPPELLA, Giacinto. "Acerca do cosmopolitismo intelectual de D. Francisco Manuel de Melo". In: Brasilia, v.XI, Coimbra, 1961, pp.59-76.

MARTÍNEZ ARANCON, Ana. La batalla en torno a Góngora. Barcelona: Antoni Bosch, 1978.

MARTINS, Paulo. Elegia romana: construção e efeito. São Paulo: Humanitas, 2009.

MARAVALL, José Antonio. La cultura del barroco: análisis de una estructura histórica. Barcelona : Editorial Ariel, 1990.

MARQUILHAS, Rita. A faculdade das letras: leitura e escrita em Portugal no século XVII. Lisboa: Imprensa Nacional-Casa da Moeda, 2000. 
MIRANDA, José da Costa. Manuel Pires de Almeida - crítico do século XVII, e os seus manuscritos: lugar de Camões e de alguns poetas e teorizadores italianos. In: Separata da Revista Brotéria, vol.111, Lisboa, 1980, pp.5-13.

MOLINO, Jean. “Qu'est-ce que le style au XVII" siècle?”. In: Critique et Création Littéraires en France au XVII ${ }^{e}$ Siècle. Paris: Éditions du Centre National de la Recherche Scientifique, 1977, pp.337-356.

MONTES, José Ares. Góngora y la Poesía Portuguesa del Siglo XVII. Madrid: Gredos, 1956.

MOREIRA, Marcello. Critica Textualis in Caelum Revocata? Uma Proposta de Edição e Estudo da Tradição de Gregório de Matos e Guerra. São Paulo: Edusp, 2011.

MUHANA, Adma. A epopéia em prosa seiscentista: uma definição de gênero. São Paulo: Unesp; Fapesp, 1997.

. “Causas da poesia na Poética”. In: Phaos - Revista de Estudos Clássicos, Campinas, v.4, 2004, pp.97-109.

. "Elogio de Górgias". In: Letras Clássicas, São Paulo, USP, n.4, 2000, pp.35-50.

. "Introdução". In: OLIVEIRA, Manuel Botelho de. Poesia completa: Música do Parnasso, Lira Sacra. São Paulo: Martins Fontes, 2005, pp.XI-LXXXVIII.

. Nas envolturas das ficções não há participação da retórica: mera poesis est.

Tese de Livre-Docência. Faculdade de Filosofia, Letras e Ciências Humanas, Universidade de São Paulo, São Paulo, 2011.

. "O gênero epistolar: diálogo per absentiam”. In: Discurso. São Paulo, USP, n.31, 2000, pp.329-345.

. "Posfácio". In: REBELO, Gaspar Pires de. Infortúnios trágicos da constante Florinda. São Paulo: Globo, 2006, pp.327-375.

OROZCO DÍAZ, Emilio. En torno a las “Soledades” de Góngora. Ensayos, estudios y edición de textos críticos de la época referentes al poema. Granada: Universidad de Granada, 1969.

Lope y Góngora frente a frente. Madrid: Gredos, 1973.

PARIENTE, Ángel. En torno a Góngora. Madrid: Júcar, 1986.

PÉCORA, Alcir. Máquina de Gêneros. São Paulo: Edusp, 2001. . Teatro do Sacramento. São Paulo: Edusp, 1994. 
PIMPÃO, Álvaro Júlio da Costa. A lírica camoniana no século XVII: Faria e Sousa e Álvares da Cunha. In: Brotéria. Série mensal, vol.XXXV, pp.14-27, Lisboa, julho de 1942.

PINEDA, Victoria. La imitación como arte literario en el siglo XVI español. Sevilla: Diputación Provencial de Sevilla, 1994.

PIRES, Maria Lucília Gonçalves. A crítica camoniana no século XVII. Lisboa: Instituto de Cultura e Língua Portuguesa; Divisão de Publicações (Biblioteca Breve/Volume 64), 1982.

. "O tema da «guerra interior» nas Obras Métricas de D. Francisco Manuel de Melo". In: Xadrez de palavras: estudos de literatura barroca. Lisboa: Edições Cosmos, 1996, pp.53-74.

. "Reflexões acerca da poética barroca". In: Claro-Escuro: Revista de Estudos Barrocos. Lisboa: Quimera, 1988, pp.39-46.

PIVA, Luiz. "Discurso Apologético de Manuel Pires de Almeida sobre a proposição de Os Lusíadas". In: Revista Camoniana, v.3, pp.235-258, São Paulo, 1971.

PONTES, Maria de Lourdes Belchior. Bibliografia de António da Fonseca Soares (Frei António das Chagas). Lisboa: Centro de Estudos Filológicos, 1950.

. “Góngora e os cultos, segundo a retórica conceptista, de Francisco Leitão Ferreira - Nova Arte de Conceitos". In: Separata do Vol. III das Actas do V Colóquio Internacional de Estudos Luso-Brasileiros, Coimbra, 1966, pp.5-16.

PUNTONI, Pedro. "Bernardo Vieira Ravasco, secretário do Estado do Brasil: poder e elites na Bahia do século XVII”. In: Novos Estudos. CEBRAP, São Paulo, v. 68, 2004, pp.107-126.

RAGUSA, Giuliana. Fragmentos de uma deusa: a representação de Afrodite na lírica de Safo. Campinas: Editora da Unicamp, 2005.

. Lira, mito e erotismo: Afrodite na poesia mélica grega arcaica. Campinas: Editora da Unicamp, 2010.

REBELO, Luis de Sousa. A tradição clássica na literatura portuguesa. Lisboa : Livros Horizonte, 1982.

RODRIGUES, Marina Machado. Camões e os poetas do século XVI. Rio de Janeiro: EdUERJ, 2006.

ROUGEMONT, Denis de. L'amour et l'occident. Paris: Plon, 1982.

ROSES LOZANO, Joaquín. Una poética de la oscuridad. La recepción crítica de las “Soledades" en el siglo XVII. Madrid: Támesis, 1994. 
SAID ALI, Manuel. Versificação portuguesa. São Paulo: EDUSP, 2006.

SANTOS, Zulmira. "Algumas notas sobre o «amor», o «desengano» e o «artifício» nas Obras Métricas (1665) de D. Francisco Manuel de Melo”. In: Península-Revista de Estudos Ibérios, n.6, pp.121-130, Faculdade de Letras da Universidade do Porto, 2009.

SARAIVA, Antônio José. O discurso engenhoso: estudos sobre Vieira e outros autores barrocos. São Paulo: Perspectiva, 1980.

SAUNDERS, J.L. Justus Lipsius: The Philosophy of Renaissance Stoicism. New York: The Liberal Arts Press, 1955.

SHEPARD, Sanford. El Pinciano y las Teorías Literarias del Siglo de Oro. Segunda edición aumentada. Madrid: Gredos, 1970.

SOARES AMORA, Antônio Augusto. Manuel Pires de Almeida - um crítico inédito de Camões. Tese apresentada ao concurso para a cadeira de Literatura Portuguesa da Faculdade de Filosofia, Ciências e Letras da Universidade de São Paulo. São Paulo, 1955.

SPINA, Segismundo. A lírica trovadoresca. São Paulo: Edusp, 1996. . Introdução à Poética Clássica. São Paulo: Martins Fontes, 1995. . Manual de versificação românica medieval. Cotia: Ateliê, 2003.

Stö̈cisme et Christianisme à la Renaissance, Cahiers V.L. Saulnier 23. Reponsable Catherine Magnien. Paris: Rue d'Ulm/Presses de l'École normale supérieure, 2006.

TAGLIABUE, Guido Morpurgo. "Aristotelismo e Barocco". In: Retorica e Barocco. Atti del III Congresso Internazionale di Studi Umanistici. A cura di Enrico Castelli. Roma: Fratelli Bocca, 1935, pp.119-195.

TEIXEIRA, Ivan. "A poesia aguda do engenhoso fidalgo Manuel Botelho de Oliveira". In: Música do Parnaso. Cotia: Ateliê Editorial, 2005, pp.7-96. Mecenato Pombalino e Poesia Neoclássica. São Paulo: Editora da Universidade de São Paulo, 1999.

TERRY, Arthur. Seventeenth-century spanish poetry: the power of artifice. Cambridge: Cambridge University Press, 1993.

TOPA, Francisco. Edição crítica da obra poética de Gregório de Matos. Tese de Doutoramento em Literatura Brasileira apresentada à Faculdade de Letras da Universidade do Porto. Porto, 1999. 
VASCONCELOS, Carolina Michaëlis de. A saudade portuguesa: divagações filológicas e literar-históricas em volta de Inês de Castro e do cantar velho “Saudade minha - quando te veria?”. Porto: Renascença Portuguesa, 1914.

VEYNE, Paul. A elegia erótica romana (o amor, a poesia e o ocidente). Tradução de Milton Meira do Nascimento e Maria das Graças de Souza Nascimento. São Paulo: Brasiliense, 1985.

WEINBERG, Bernard. Estudios de poética clasicista: Robortello, Escalígero, Minturno, Castelvetro. Madrid: Arco/Libros, S.L., 2003.

ZANTA, Léontine. La Renaissance du Stoücisme au XVI siècle. Thèse pour le Doctorat ès Lettres, présentée à la Faculté des Lettres de l'Unversité de Paris. Paris: Honoré Champion, 1914. 